\title{
On the alignment of the European Patent Convention and the Patent Cooperation Treaty with requirements of the Patent Law Treaty
}

Citation for published version (APA):

Mulder, C. A. M. (2011). On the alignment of the European Patent Convention and the Patent Cooperation Treaty with requirements of the Patent Law Treaty. [Doctoral Thesis, Maastricht University]. Helze BV Publisher. https://doi.org/10.26481/dis.20111219cm

Document status and date:

Published: 01/01/2011

DOI:

$10.26481 /$ dis. $20111219 \mathrm{~cm}$

Document Version:

Publisher's PDF, also known as Version of record

Please check the document version of this publication:

- A submitted manuscript is the version of the article upon submission and before peer-review. There can be important differences between the submitted version and the official published version of record.

People interested in the research are advised to contact the author for the final version of the publication, or visit the DOI to the publisher's website.

- The final author version and the galley proof are versions of the publication after peer review.

- The final published version features the final layout of the paper including the volume, issue and page numbers.

Link to publication

\footnotetext{
General rights rights.

- You may freely distribute the URL identifying the publication in the public portal. please follow below link for the End User Agreement:

www.umlib.nl/taverne-license

Take down policy

If you believe that this document breaches copyright please contact us at:

repository@maastrichtuniversity.nl

providing details and we will investigate your claim.
}

Copyright and moral rights for the publications made accessible in the public portal are retained by the authors and/or other copyright owners and it is a condition of accessing publications that users recognise and abide by the legal requirements associated with these

- Users may download and print one copy of any publication from the public portal for the purpose of private study or research.

- You may not further distribute the material or use it for any profit-making activity or commercial gain

If the publication is distributed under the terms of Article $25 \mathrm{fa}$ of the Dutch Copyright Act, indicated by the "Taverne" license above, 
On the Alignment of the European Patent Convention and the PATENT COOPERATION TREATY WITH REQUIREMENTS OF THE PATENT LAW TREATY

Cees Mulder 
On the Alignment of the European Patent Convention and the Patent Cooperation Treaty with Requirements of the Patent Law Treaty Dr. C.A.M. Mulder

NUR-code: 828

Helze BV Publisher

Helze 1

NL - 5662 JE Geldrop

The Netherlands

www.helze.com

e-mail: helze@helze.com

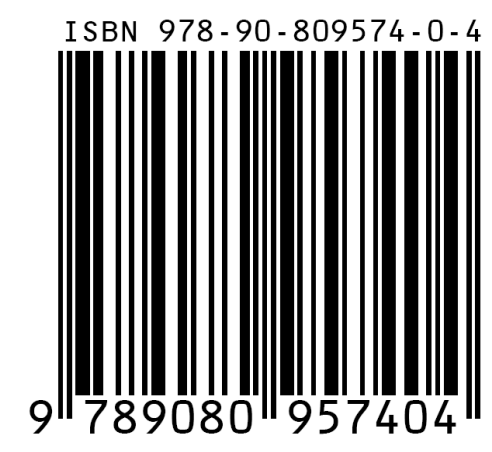




\title{
ON the Alignment OF the EuROPEAN PATENT CONVENTION AND THE PATENT COOPERATION TREATY WITH REQUIREMENTS OF THE PATENT LAW TREATY
}

\author{
DISSERTATION \\ To obtain the degree of Doctor \\ At Maastricht University \\ On the authority of the Rector Magnificus, \\ Prof. dr. G.P.M.F. Mols \\ In accordance with the decision of the Board of Deans, \\ To be defended in public \\ On Monday December 19, 2011, at 14:00 hours \\ by \\ Dr. Cornelis Antonius Maria Mulder
}




\section{Supervisors}

Prof. mr. Anselm Kamperman Sanders PhD (Lond)

\section{Assessment Committee}

Prof. mr. dr. Gerard-René de Groot (Chairman)

Prof. dr. Michael Faure

Dr. iur. Dieter Stauder (Centre d'Études Internationales de la Propriété Intellectuelle (CEIPI), Université de Strasbourg) 
Receive what cheer you may;

The night is long that never finds the day.

W. Shakespeare: Macbeth, Act 4, Scene 3 
This page was left blank intentionally. 


\section{Acknowledgements}

The completion of this thesis brings to a close an ambition which I have nursed for many years. While working as a Patent Attorney at Philips Electronics and, later on, at DeltaPatents, I hardly ever found the time to sit down and think things over, let alone have a scientific discussion, or draft an article on a subject in the field of intellectual property, in particular, European patent law. By choosing to step down as partner from DeltaPatents and accepting a part-time job as Lecturer in the "Advanced Master Intellectual Property Law and Knowledge Management (LLM/MSC)" in the Department of International and European Law at the Faculty of Law of Maastricht University, I found the time to do research.

My sincere thanks go to all those who have contributed to the completion of this thesis. Although I will not be able to mention everyone, there are a few people who must be mentioned here.

First of all, I am indebted to Prof. Anselm Kamperman Sanders who inspired me to start thinking about doing research for a second $\mathrm{PhD}$, this time not in Physics (Leiden, May 1982) but in Law. Anselm supported me in selecting the subject, guided me and kept me on track.

I am also grateful to Dr. Dieter Stauder with whom I worked together for almost 15 years in the Centre d'Etudes Internationales de la Propriété Intellectuelle (CEIPI) at Strasbourg University while teaching Trainee Patent Attorneys preparing for the European Qualifying Examination. Throughout the years, Dieter inspired me with his attitude of critical thinking; in addition, we became friends.

Prof. Allison Firth (Newcastle and Surrey) deserves a special acknowledgement because, during the initial stages of my research, she formulated a few questions which enabled me to pinpoint the focus of my research subject.

Special thanks go to Dr. Derk Visser who was one of my teachers at the Philips Patent Department in the period when I was preparing for the European Qualifying Examination. From Derk I learned to focus on what is essential to know at the Exam and he also showed me his love for scientific dispute. His input on the chapters related to aligning the European Patent Convention with the requirements of the Patent Law Treaty is greatly acknowledged.

Many people have contributed to the completion of my thesis. A number of them could not be mentioned in the Articles which were published, but they can be mentioned here. I would like to acknowledge the following persons of the World Intellectual Property Organization (WIPO, Geneva): Philippe Baechtold for his interest and support and Tomoko Miyamoto for contributing to my research. Amongst others, Tomoko explained many things about the origin and background of the Patent Law Treaty and made 
available many preparatory documents. In addition, I would like to thank Claus Matthes for his support and for critically proofreading a number of draft Articles related to the aligning of the Patent Cooperation Treaty with the requirements of the Patent Law Treaty. Claus has shared his excellent insight into the Patent Cooperation Treaty with me and taught me a lot about politics. In addition, I am indebted to Matthew Bryan, Matthias Reischle and, last but not least, Rosina Bisi Kurkdjian for their interest and continuous support of my research project.

Gert Kolle (former Director at the European Patent Office, Munich) told me all about the way in which the Implementing Regulations of the European Patent Convention were brought into alignment with the requirements of the Patent Law Treaty. He shared his detailed knowledge about the reasons why the Rules currently found in the EPC 2000 were formulated in this way.

I would also like to mention Dr. Feye Meijer (former Director at Philips Research Laboratories). During the 20 years I worked at Philips Electronics in different positions, he was always willing to talk about personal matters and career routes. Eventually, Feye was the person who inspired me to become a Patent Attorney.

Of course, I have also learned a lot from my colleagues at the Department of International and European Law. In particular, I would like to mention Dalindyebo Shabalala and Rogier Creemers.

I would also like to thank Peter Sistermans who corrected and reformulated my English in the majority of the chapters of this thesis.

Although my parents died in the period after I defended my first thesis in 1982, I would like to acknowledge them for their inspiration; persons are not dead as long as they are remembered with love.

I would also like to mention Geertje Stienstra who 30 years ago became my assistant in my first job at Philips Research Laboratories. The collaboration resulted in my longest and best friendship; during the years we have shared so many things.

Last but not least, special thanks go to my husband Tim van Heijst for his interest, patience, support and also for manufacturing and distributing this book. I am so lucky I met him in 1999 and thank him for enriching my life in a way no thesis ever could.

Maastricht, 1 November 2011. 


\section{Table of Contents}

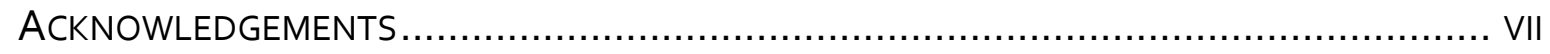

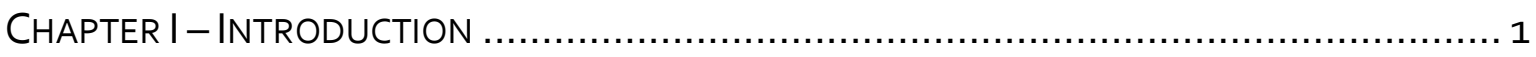

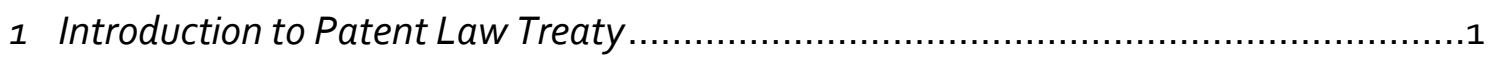

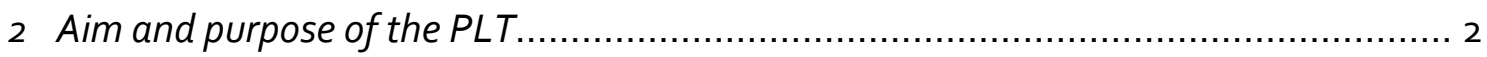

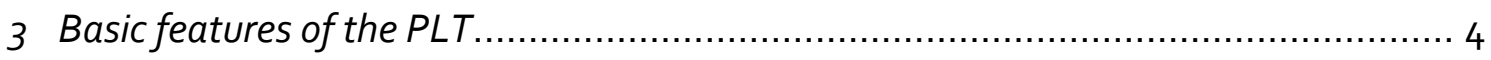

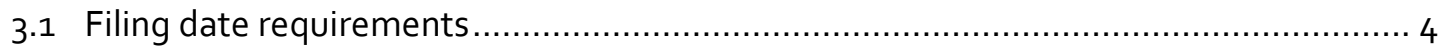

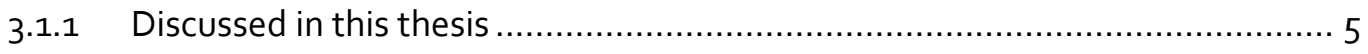

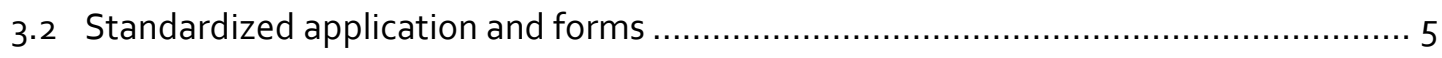

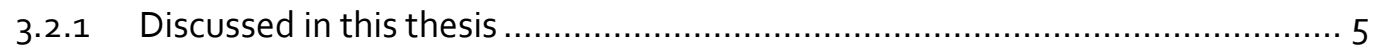

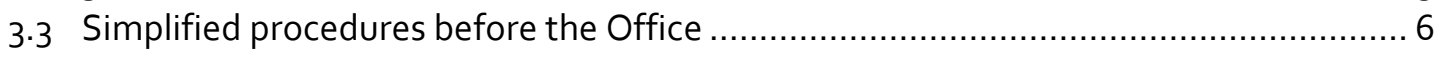

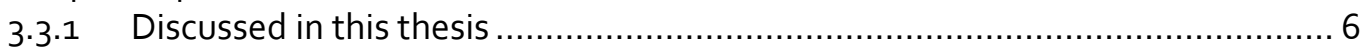

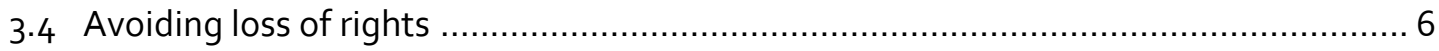

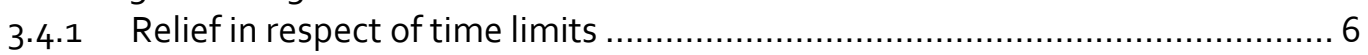

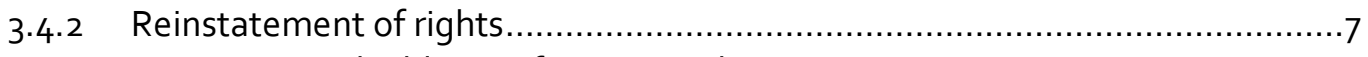

3.4.3 Correction and addition of a priority claim …............................................

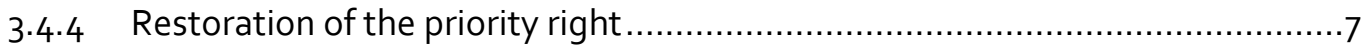

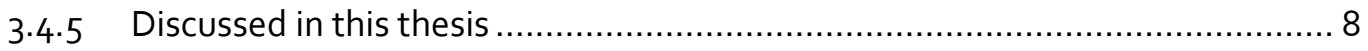

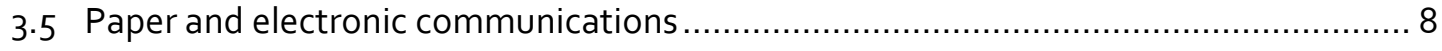

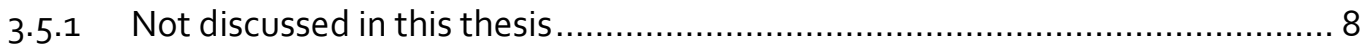

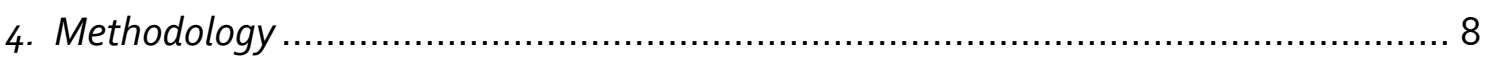

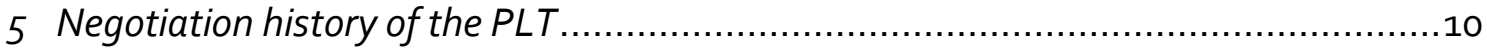

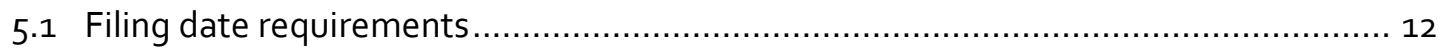

5.1.1 Committee of Experts on the Patent Law Treaty...................................... 12

5.1.2 Standing Committee on the Law of Patents .............................................. 17

5.1.3 Diplomatic Conference for the Adoption of the PLT ................................. 20

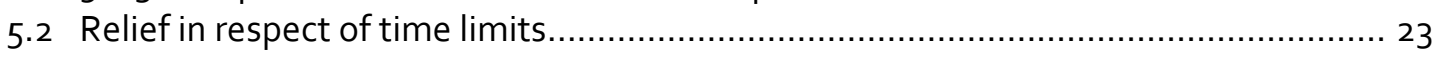

5.2.1 Committee of Experts on the Patent Law Treaty....................................... 23

5.2.2 Standing Committee on the Law of Patents............................................. 26

5.2.3 Diplomatic Conference for the Adoption of the PLT ................................. 32

5.4 Restoration of priority right .......................................................................... 34

5.4.1 Committee of Experts on the Patent Law Treaty ..................................... 34

5.4.2 Standing Committee on the Law of Patents ................................................. 37

5.4.3 Diplomatic Conference for the Adoption of the PLT ................................. 39

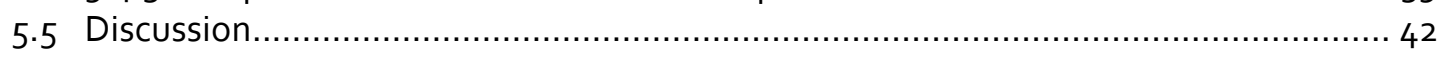

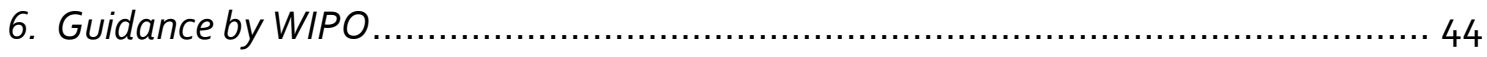

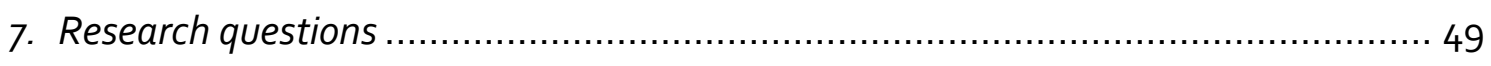

CHAPTER II - FILING DATE REQUIREMENTS UNDER THE EPC - AN OPTION TO EXTEND

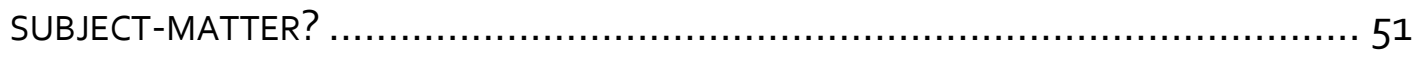

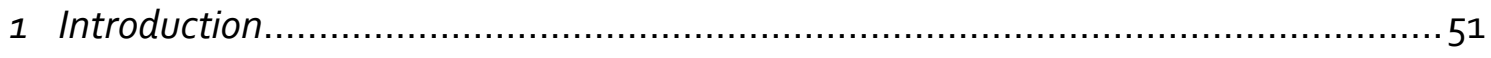

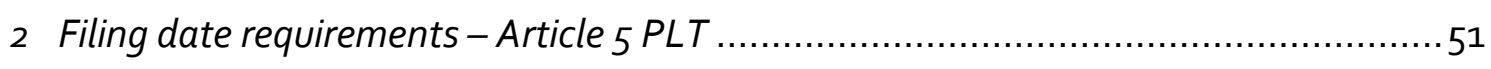

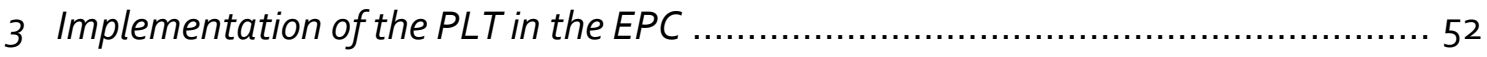

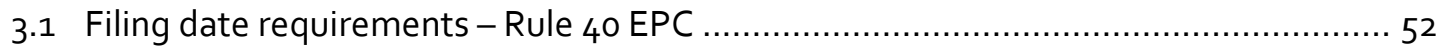

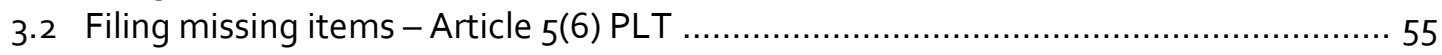

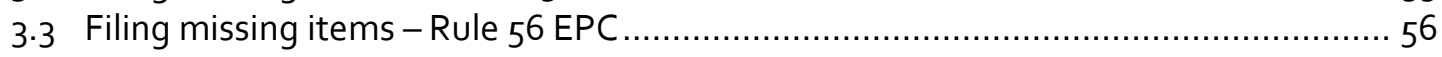

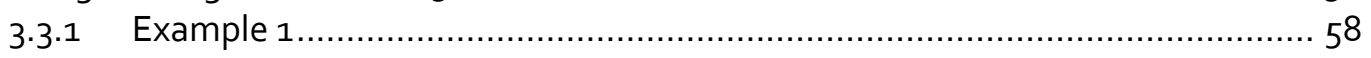




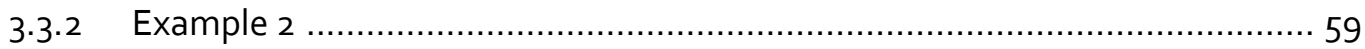

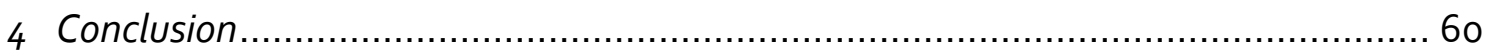

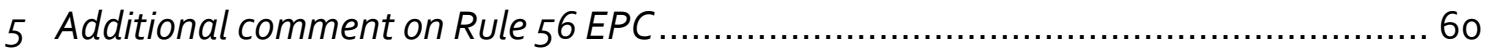

CHAPTER III - FILING DATE REOUIREMENTS UNDER THE EPC - FILING BY REFERENCE

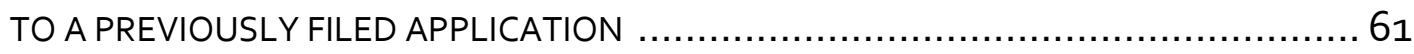

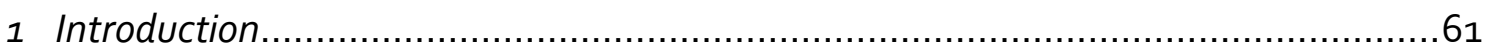

2 Filing by reference to a previously filed application - Article 5(7) and Rule 2(5)

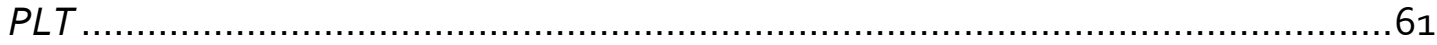

3 Implementation of Rule 2(5) PLT in Rule 40 and 55 EPC .................................63

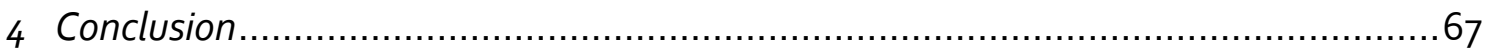

CHAPTER IV - FILING DATE REOUIREMENTS UNDER THE PCT - ALIGNMENT WITH THE PLT? 69

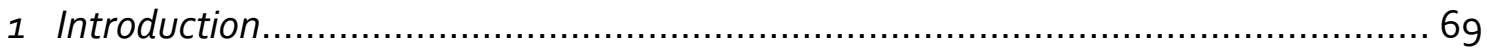

2 Main purpose of this chapter .................................................................... 70

3 Relationship between the PLT and the PCT ................................................. 71

4 Alignment of the Patent Cooperation Treaty with the Patent Law Treaty …...............74

5 Inconsistencies in provisions dealing with filing date requirements ..........................75

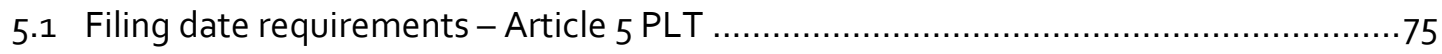

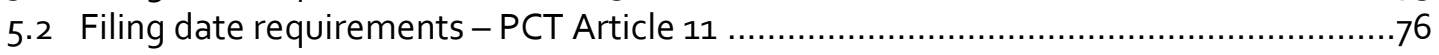

5.3 Filing date requirements - Differences / matter of concern ..................................... 77

5.3.1 Right to file an international application ................................................... 77

5.3.2 Language of filing an international application............................................

$5.3 .3 \quad$ Intended as an international application...............................................

5.3.4 Designation of at least one Contracting State ..........................................78

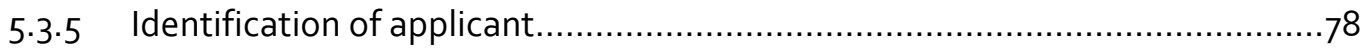

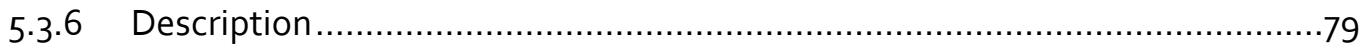

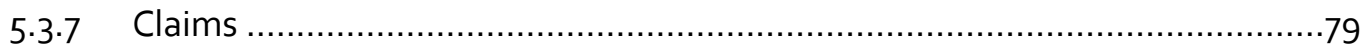

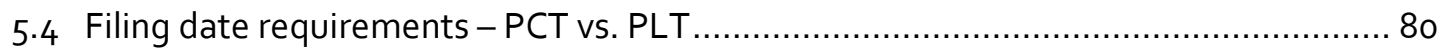

5.5 Filing by reference to a previously filed application - Article 5(7) PLT .................... 81

5.6 Filing by reference to a previously filed application - PCT ................................. 82

6 Further inconsistencies in provisions dealing with defects which may affect the

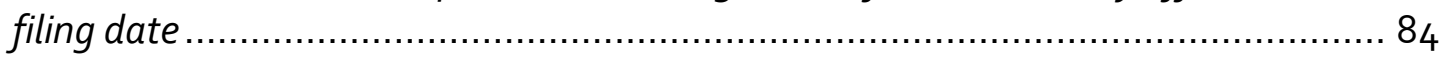

6.1 Filing missing parts of the description or missing drawings - Article 5(6) PLT ............ 84

6.2 Filing missing parts of the description or missing drawings - PCT Rule $20.5 \ldots \ldots \ldots \ldots . . .85$

6.2.1 Filing missing parts - Re-dating the international application ...................... 86

6.2.2 Filing missing parts without re-dating - Incorporation by reference ................87

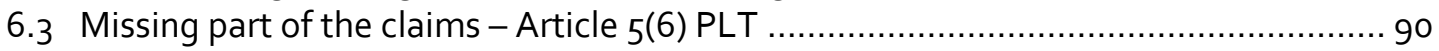

6.4 Missing part of the claims - PCT Rule 20.5 …................................................... 90

6.5 Missing entire description of missing entire set of claims - Article 5(6) PLT ............... 91

6.6 Missing entire description of missing entire set of claims - PCT Rule 20.6 ................ 91

7 Filing an international application by reference to a previously filed application .........93

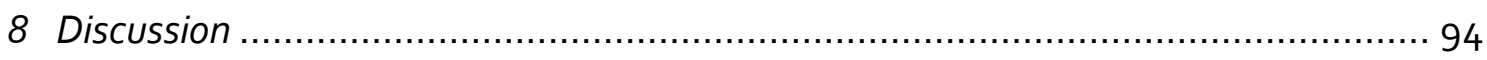

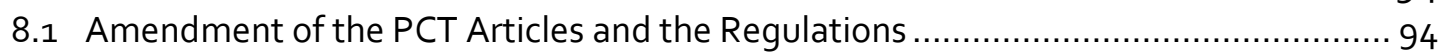

8.2 "Bending" of PCT Articles in the Regulations …................................................... 94

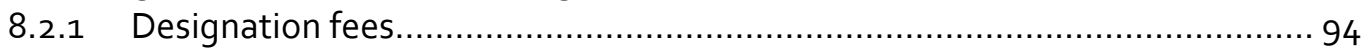

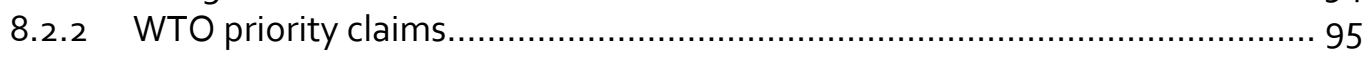


8.2.3 Misalignments in the Regulations............................................. 96

8.3 Discussions in the Working Group on Reform of the PCT ............................... 96

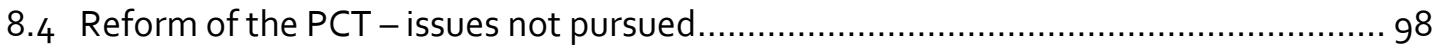

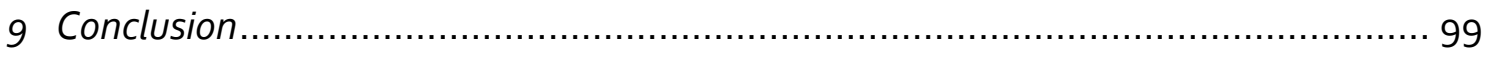

CHAPTER V - PERIODS AND REMEDIES UNDER THE EPC - COMPLIANCE OF THE EPC WITH THE PLT - PART I - EXTENSION OF PERIODS AND FURTHER PROCESSING ... 101

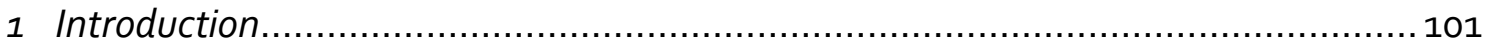

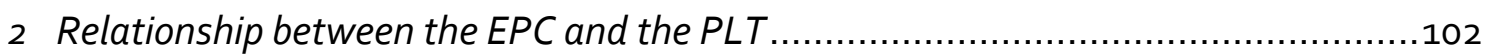

3 Relief in respect of time limits - Article 11 and Rule 12 PLT .......................... 103

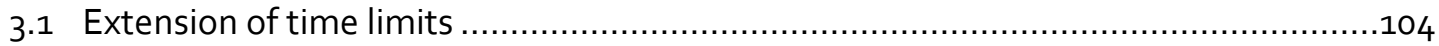

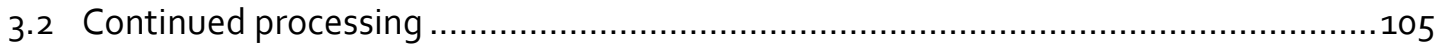

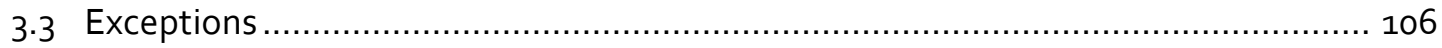

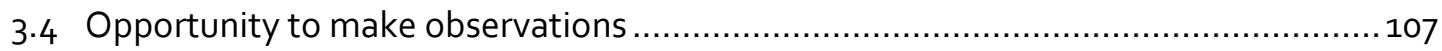

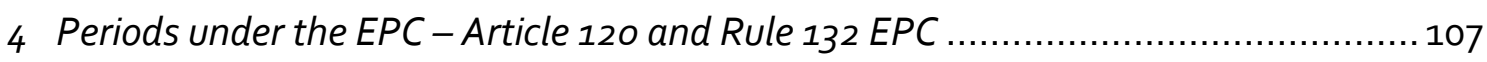

4.1 The use of the terms "time limit" and "period" in the EPC ..............................107

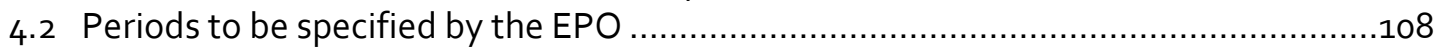

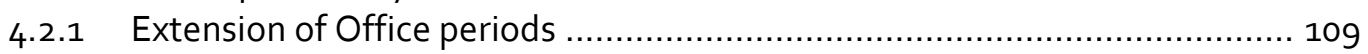

4.2.2 EPC Office periods versus PLT Office time limits ...............................110

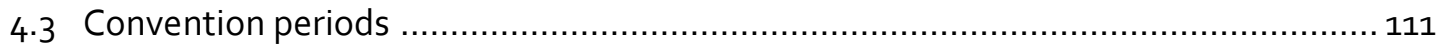

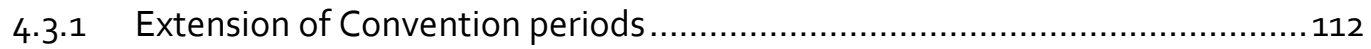

4.3.2 EPC Convention periods and PLT time limits..................................112

5 Further processing under the EPC - Article 121 and Rule 135 EPC.......................112

5.1 EPC Office periods and further processing ................................................. 114

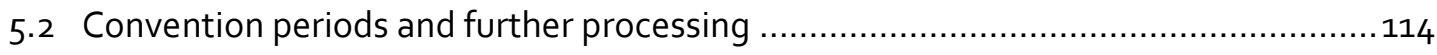

5.3 EPC further processing versus PLT continued processing ............................... 117

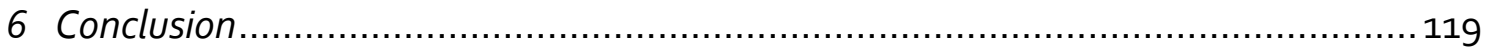

CHAPTER VI - PERIODS AND REMEDIES UNDER THE EPC - COMPLIANCE OF THE EPC WITH THE PLT - PART II - RE-ESTABLISHMENT OF RIGHTS $\ldots \ldots \ldots \ldots \ldots \ldots \ldots \ldots \ldots . \ldots \ldots \ldots \ldots \ldots \ldots$

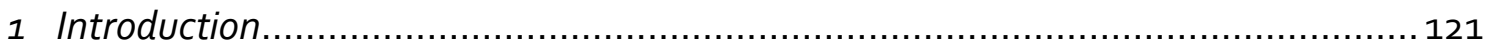

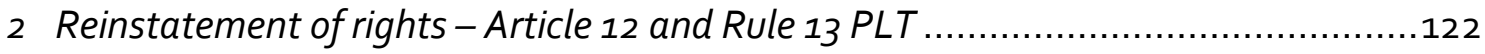

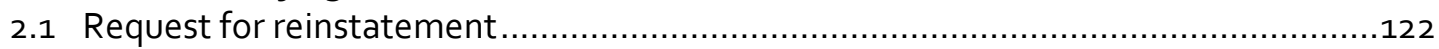

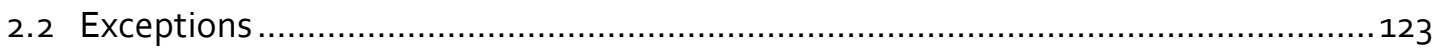

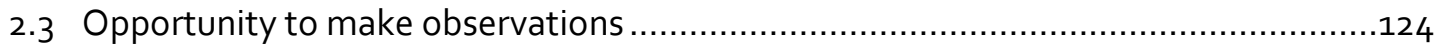

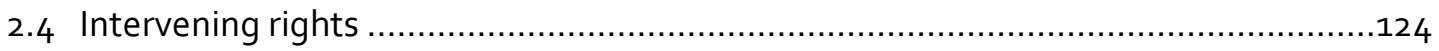

3 Restoration of the priority right - Article 13 and Rule 14 PLT ..........................124

3.1 Delayed filing of the subsequent application - Article 13(2) and Rule 14(4) and

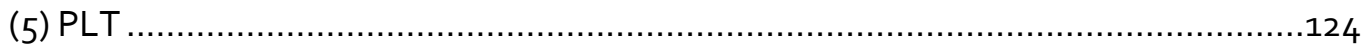

3.2 Failure to file a copy of the earlier application - Article 13(3) and Rule 14(6) and

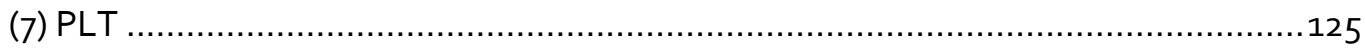

4 Re-establishment of rights under the EPC - Article 122 and Rule 136 EPC.............126

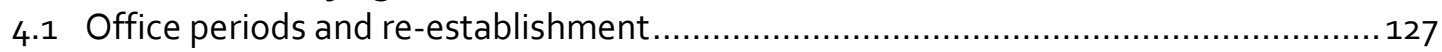

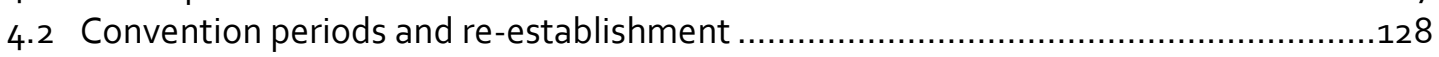

4.3 EPC re-establishment versus PLT reinstatement and restoration ....................... 129

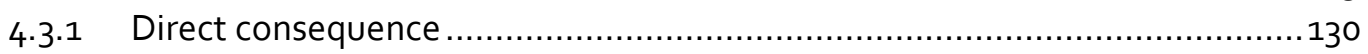

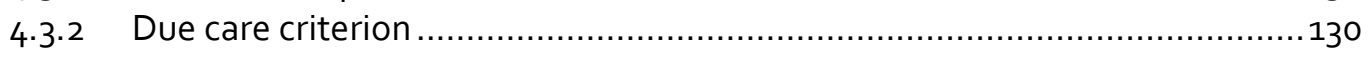

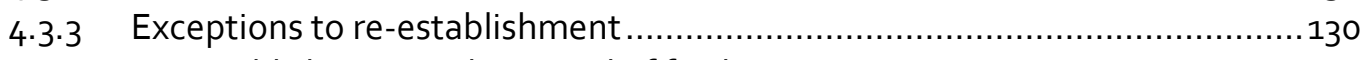

4.3.4 Re-establishment in the period of further processing ......................... 131 


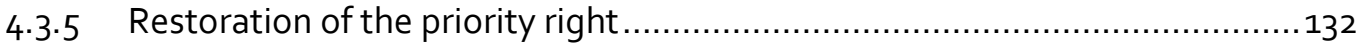

4.3.5.1 Re-establishment in the priority period...................................... 132

4.3.5.2 Re-establishment in the period for filing of a copy of the priority application .......................................................... 132

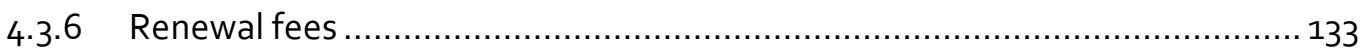

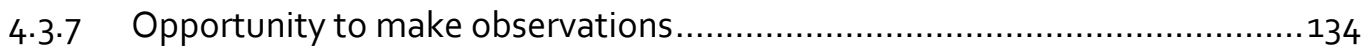

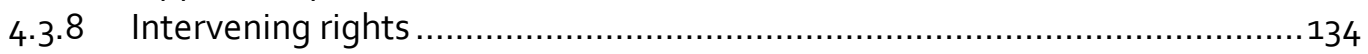

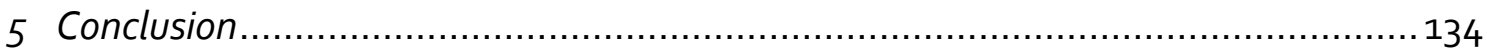

CHAPTER VII - TIME LIMITS AND REMEDIES UNDER THE PCT - COMPLIANCE OF THE

PCT WITH THE PLT? .......................................................... 137

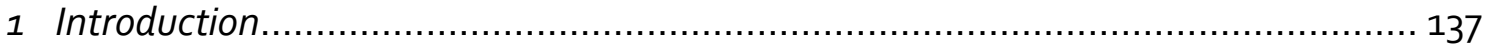

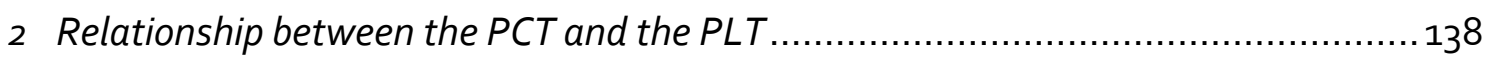

3 Relief in respect of time limits - Article 11 and Rule 12 PLT ..........................140

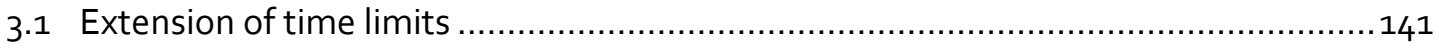

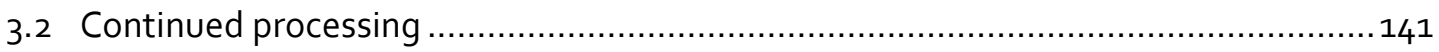

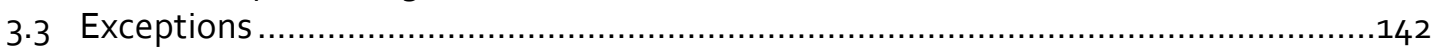

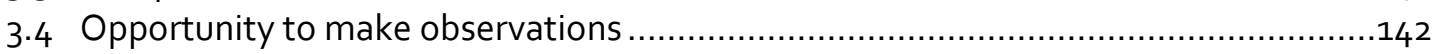

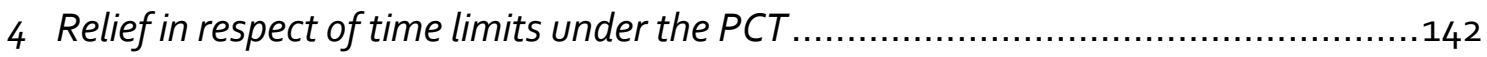

4.1 Time limits to be specified by an Office or Authority under the PCT .....................142

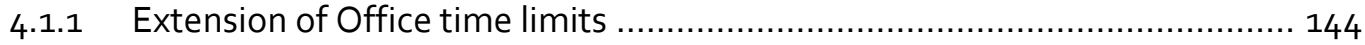

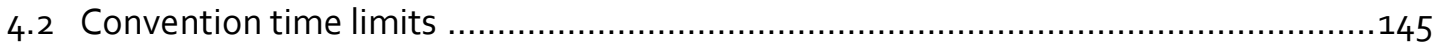

4.2.1 Extension of Convention time limits .......................................... 146

4.2.2 Convention time limits which may not be extended ............................ 147

4.3 Duration and extension of PCT time limits - Influence of the PLT - Discussion........ 149

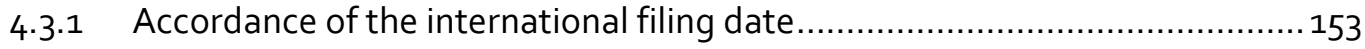

4.3.2 Correction of deficiencies after filing the international application.............153

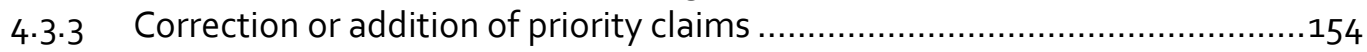

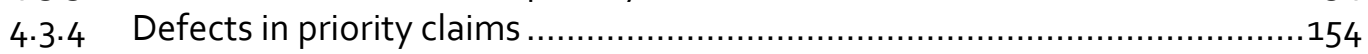

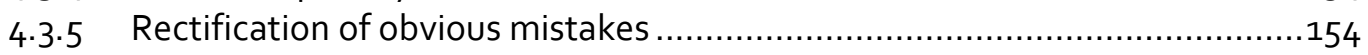

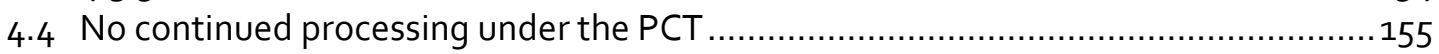

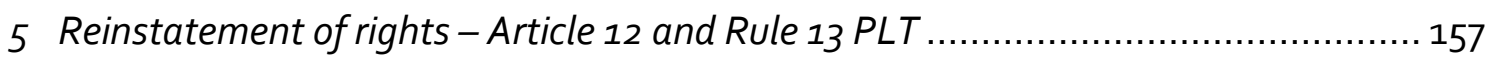

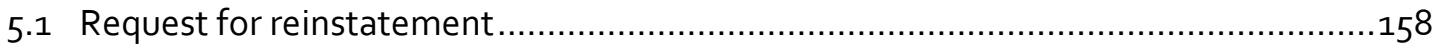

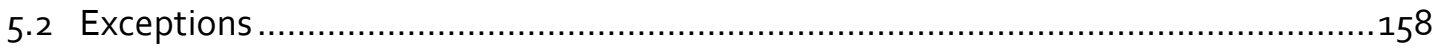

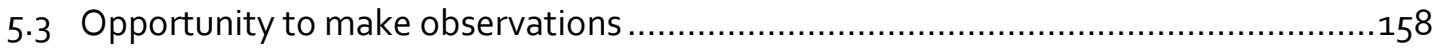

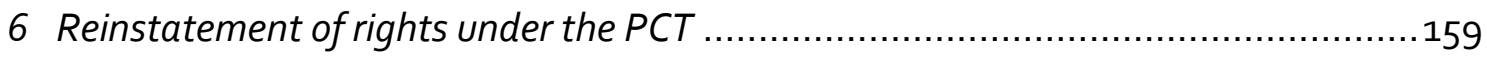

7 Restoration of the priority right - Article 13 and Rule 14 PLT ..........................159

7.1 Delayed filing of the subsequent application - Article 13(2) and Rule 14(4)

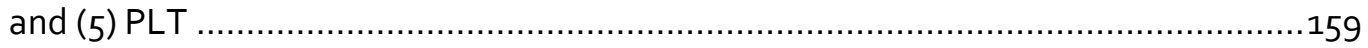

7.2 Failure to file a copy of the earlier application - Article 13(3) and Rule 14(6)

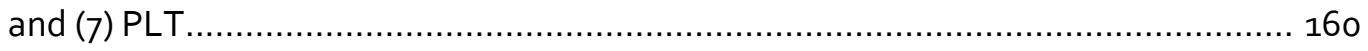

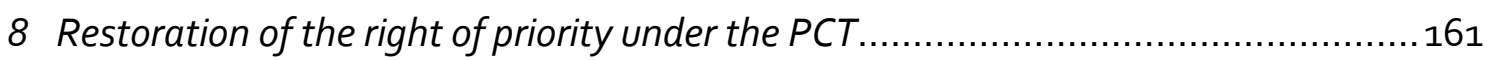

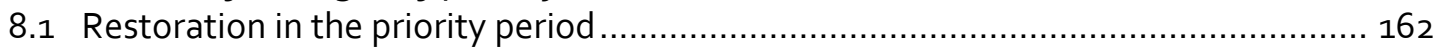

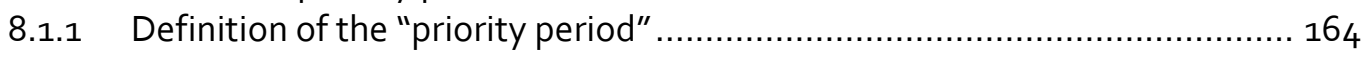

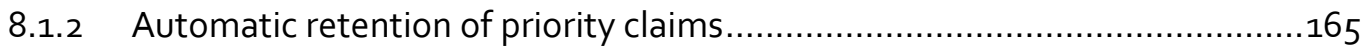

8.2 No restoration in the period for filing of a copy of the priority application

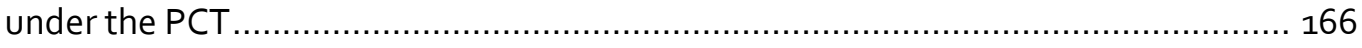

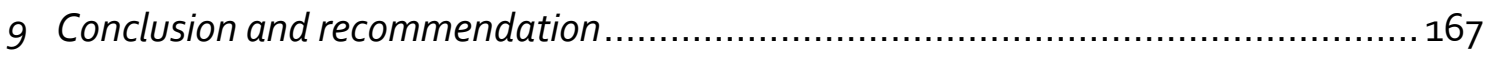

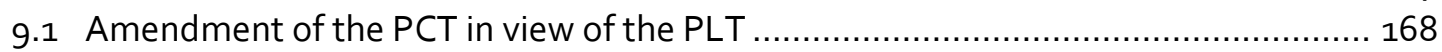


9.2 Duration and relief in respect of time limits fixed by the Office ....................... 168

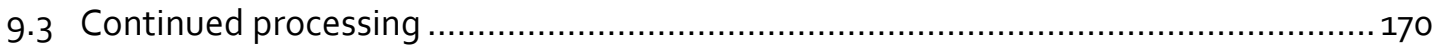

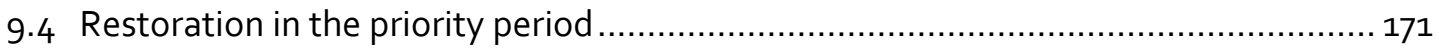

9.5 Restoration in the period for filing of a copy of the priority application................. 171

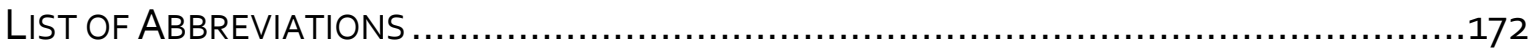

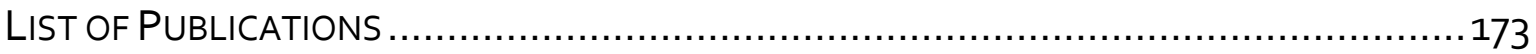

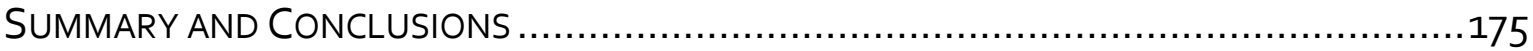

1 Negotiation history of the Patent Law Treaty........................................... 177

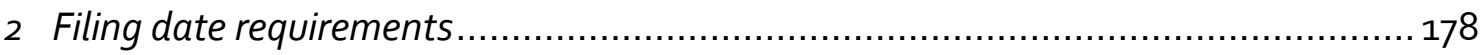

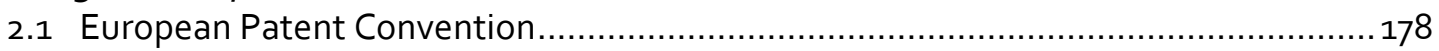

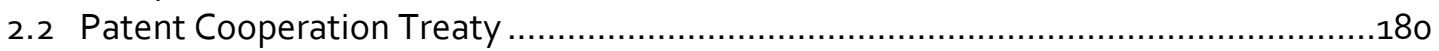

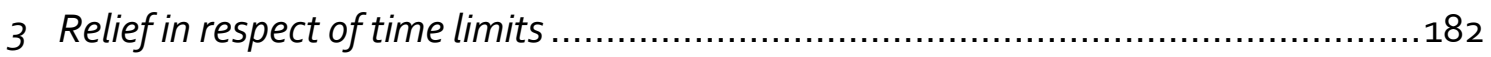

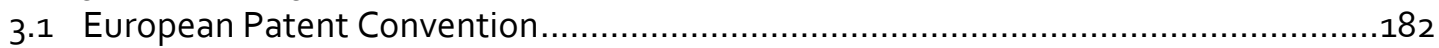

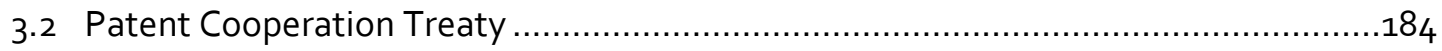

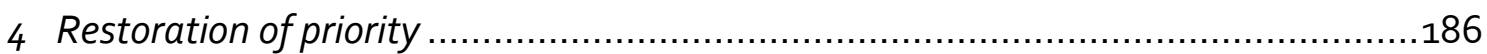

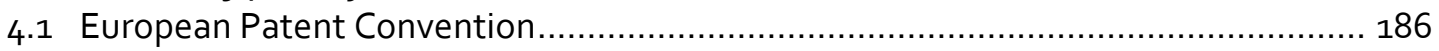

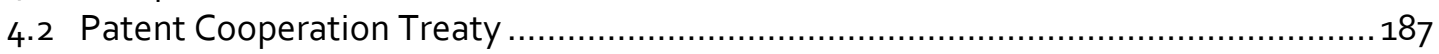

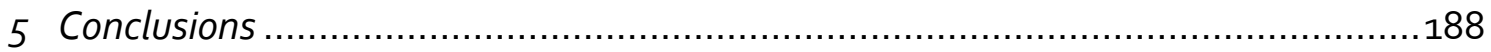

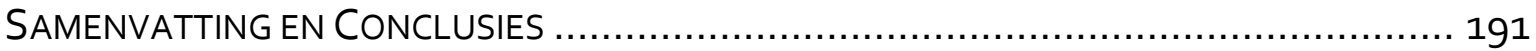

1 Onderhandelingsgeschiedenis van het Verdrag inzake Octrooirecht .................... 193

2 Vereisten voor de toekenning van een indieningsdatum ........................................194

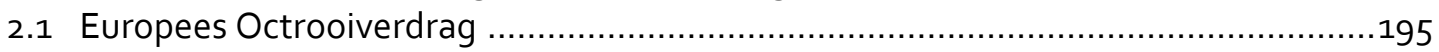

2.2 Verdrag tot Samenwerking inzake Octrooien ........................................... 196

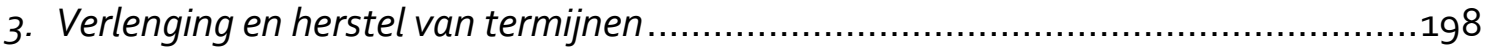

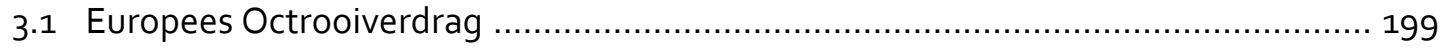

3.2 Verdrag tot Samenwerking inzake Octrooien ...............................................201

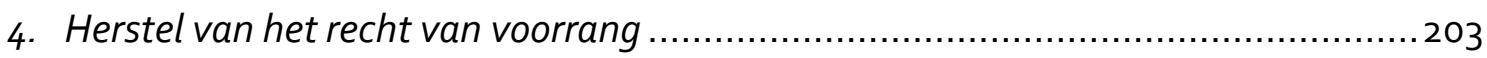

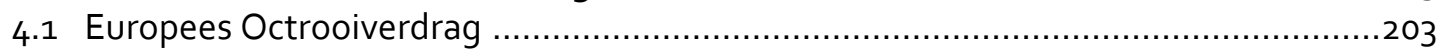

4.2 Verdrag tot Samenwerking inzake Octrooien ............................................. 204

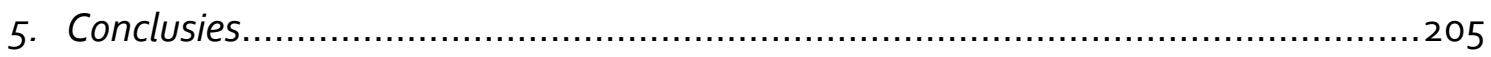

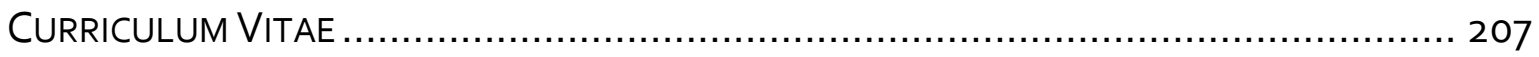


This page was left blank intentionally. 


\section{Chapter I-Introduction ${ }^{1}$}

\section{Introduction to Patent Law Treaty}

The Patent Law Treaty (PLT) was concluded during a Diplomatic Conference held at the World Intellectual Property Organization (WIPO) in Geneva (Switzerland) from May 11 to June $2,2000 .{ }^{2}$ The PLT is open to States member of WIPO and/or States party to the Paris Convention for the Protection of Industrial Property ${ }_{i}{ }^{3}$ it is also open to certain intergovernmental organizations, such as the European Patent Organization. ${ }^{4}$ Instruments of ratification or accession must be deposited with the Director General of WIPO. The PLT entered into force on April 28, 2005.

The Patent Law Treaty emanated from discussions on the reform of substantive patent law that began in 1984. Those discussions continued until June 1991, during which a first part of a Diplomatic Conference to conclude a "Treaty Supplementing the Paris Convention as far as Patents are Concerned ${ }^{\prime 5}$ The second part of the Diplomatic Conference was scheduled for July 1993, but did not take place. In January 1994, the United States discontinued the discussion on substantive patent law harmonization due to a lack of domestic support for the effort. ${ }^{6}$ The international community was disappointed by the ensuing "loss of momentum" on the subject of substantive patent law harmonization as a result of the position of the United States.

1 Parts of this Chapter in relation to the Negotiation history of the PLT have been submitted for publication in Intellectual Property Quarterly: Cees Mulder: "On the Negotiation History of the Patent Law Treaty".

2 Patent Law Treaty, WIPO Publication No. 258(E). See http://www.wipo.int/treaties/en/ip/plt/.

3 Paris Convention for the Protection of Industrial Property, WIPO Publication No. 201(E). See http://www.wipo.int/treaties/en/ip/paris/.

4 At present, the European Patent Organization is not a Contracting Party to the Patent Law Treaty. The option for Intergovernmental Organisations to become Party to the PLT was created in Article 20(2) PLT. In addition, the European Patent Organization is explicitly mentioned in Article 20(3) and Article 26 PLT as one of the Regional Patent Organisations that may become Party to the PLT.

In the Basic Proposal for the Revision of the European Patent Convention (issued in preparation of the Revision Conference in November 2000), the European Patent Organization indicated its wish to become a Contracting Party to the PLT. See "Basic Proposal for the Revision of the European Patent Convention"; Document MR/2/oo, Travaux Préparatoires to the EPC 2000; comment in relation to Article 80 EPC.

See

http://www.epo.org/patents/law/legal-texts/archive/epc2000/travaux/dc-documents.html.

5 "Records of the Diplomatic Conference for the Conclusion of a Treaty Supplementing the Paris Convention as far as Patents are Concerned - Volume I: First Part of the Diplomatic Conference The Hague, 1991", WIPO Publication No. 351(E).

6 "The Situation Concerning the Patent Law Treaty (PLT)" (memorandum of the International Bureau), Consultative Meeting for the further preparation of the Diplomatic Conference for the Conclusion of the Patent Law Treaty, Document PLT/CM/2 (March 1995), Items 4 and 7. 
In 1995, it was agreed that another approach for promoting harmonization, covering matters concerning the formality requirements of national and regional patent procedures, would be initiated by WIPO.7 Five sessions of the Committee of Experts on the Patent Law Treaty, ${ }_{1}^{8}$ and three sessions of its successor, the Standing Committee on the Law of Patents (SCP), ${ }^{9}$ were held to develop the "Basic Proposal" to be presented to the Diplomatic Conference for the Adoption of the Patent Law Treaty, which was held from May 11 to June 2, 2000. ${ }^{10-11}$

The Final Act of the Patent Law Treaty witnessing the Diplomatic Conference and its outcome, was signed by 104 countries and 3 Intergovernmental Organizations. At present 66 countries signed the PLT. In 2005 the PLT was in force in 11 countries; in 2011 there are 28 Contracting Parties. ${ }^{12}$

The PLT includes 27 articles and 21 rules. In addition, six Agreed Statements were adopted at the end of the Conference. ${ }^{13}$

\section{Aim and purpose of the PLT}

Since the adoption of the Patent Law Treaty (PLT), the involvement of the World Intellectual Property Organization (WIPO) has diminished because there are no centralized functions. The International Bureau of WIPO merely acts as depository of the PLT and is not in a position to give an official interpretation of the Treaty, as such interpretation is the exclusive competence of the PLT Contracting Parties.

The PLT aims at harmonizing and streamlining formal procedures relating to national and regional patent applications and maintenance of patents. In spite of the goal of harmonization, the PLT does not establish a uniform procedure for all PLT Contracting

7 "Report" (adopted by the Assembly), Assembly of the International Union for the Protection of Industrial Property (Paris Union), Document P/A/XXII/2 (October 1994).

8 Committee of Experts on the Patent Law Treaty.

See http://www.wipo.int/meetings/en/topic.jsp?group_id=53.

9 Standing Committee on the Law of Patents.

See http://www. wipo.int/meetings/en/topic.jsp?group id=61\&items=30.

10 Diplomatic Conference for the Adoption of the Patent Law Treaty.

See http://www.wipo.int/meetings/en/topic.jsp?group id=136.

11 "Records of the Diplomatic Conference for the Adoption of the Patent Law Treaty (Geneva, 2000)", WIPO Publication No 327(E).

12 PLT Contracting Parties.

See http://www. wipo.int/treaties/en/ShowResults.jsp?lang=en\&treaty id=4.

On October 19, 2011, the PLT entered into force for Kazakhstan thereby becoming the $28^{\text {th }}$ Contracting Party.

13 "Agreed Statements by the Diplomatic Conference regarding the Patent Law Treaty and the Regulations under the Patent Law Treaty" (adopted by the Diplomatic Conference on June 1 , 2000).

See http://www.wipo.int/treaties/en/ip/plt/statements.html. 
Parties by leaving many requirements optional, thereby allowing divergence in implementation between PLT Contracting Parties. ${ }^{14}$

The PLT sets forth, with one exception, maximum formal/procedural requirements that Contracting Parties may impose on patent applicants and patentees. Otherwise, PLT Contracting Parties are free to provide requirements that, from the viewpoint of applicants and owners, are more favorable than PLT requirements. ${ }^{15}$ The one exception to this freedom are the filing date requirements, which are both a maximum and a minimum, i.e., a so-called "filing-date standard." 16

The aim of the Patent Law Treaty is to simplify the formal obligations and reduce associated costs for patent applicants and owners of patents in obtaining and preserving their rights in inventions in many countries of the world. The PLT complements the existing international obligations and fosters the policy of strong intellectual property protection. The PLT simplifies the filing of an application and obtaining and maintaining of patents throughout the world and, to a large extent, promotes the merging of national and international formal requirements associated with patent applications and patents. In a birds' eye view, the principle features of the Patent Law Treaty offer the following advantages:

- The PLT simplifies and minimizes application requirements for obtaining a filing date;

- The PLT imposes a maximum on the formal requirements that a PLT Contracting Party may impose;

- The PLT eases representation requirements for formal matters;

- The PLT provides a basis for means of communications, including the electronic filing of applications;

- The PLT provides relief in respect of time limits that may be imposed by the Office of a PLT Contracting Party and re-instatement of rights where an applicant or owner has unintentionally failed to comply with a time limit and that failure has the direct consequence of causing a loss of rights; and

- The PLT provides for correction or addition of priority claims and restoration of priority rights.

14 "Basic Features to the Patent Law Treaty" (prepared by the International Bureau) (November 2006), Item 3.

See http://www.wipo.int/patent-law/en/plt.htm.

15 "Report" (adopted by the Standing Committee), Standing Committee on the Law of Patents, Document SCP/3/11 (September 1999).

See http://www.wipo.int/meetings/en/details.jsp?meeting_id=3824.

16 "Notes" (prepared by the International Bureau), Standing Committee on the Law of Patents, Document SCP/2/4 (February 1999).

See http://www.wipo.int/meetings/en/details.jsp?meeting_id=3713. 
A main feature of the PLT is that it provides standardized formality requirements for patent applications which are filed with a national or regional patent Office. Instead of defining these requirements again or differently in the PLT, it was decided to incorporate by reference the provisions of the PCT and its Regulations, wherever appropriate, into the $\mathrm{PLT} .{ }^{17}$ The main reason for this is that the PCT already regulates in detail the formality requirements with respect to patent applications. ${ }^{18}$

From the viewpoint of inventors, applicants and patent attorneys, standardization and simplification of the formality requirements lead to a reduced risk of formality errors resulting in a less frequent loss of rights. On the other hand, Offices may operate more efficiently because of the simplification of procedures and the streamlining of the process. Eventually, this will result in cost reductions on both sides.

\section{Basic features of the PLT}

In many documents, the main features of the PLT are described..$^{19-20-21}$ In the paragraphs below a condensed overview of these principle features is given. For each issue, it is indicated whether it is subject of discussion in this thesis.

\subsection{Filing date requirements}

The accordance of a date of filing is essential to deciding who has priority for the grant of a patent in each country and to determining prior art and the patentability of the invention. It is also relevant to claiming a right of priority under the Paris Convention as well as to the calculation of the term of patent protection.

Article 5 PLT sets a maximum and minimum set of requirements for obtaining a filing date and procedures to avoid loss of the filing date because of a failure to comply with other formality requirements. In principle, the Office of any PLT Contracting Party shall

${ }^{17}$ For a discussion of the issue of "incorporation by reference of PCT provisions into the PLT" see: Cees Mulder: "Filing date requirements under the PCT - Alignment with the PLT?", The WIPO Journal, Volume 2, Issue 2 (2011), pp. 173-195. An updated version of this article is included in Chapter IV of this thesis.

See http://www.wipo.int/about-wipo/en/wipo journal/.

18 "Basic Features to the Patent Law Treaty (PLT)" (prepared by the International Bureau; November 2006).

19 "The Patent Law Treaty (PLT)" in the WIPO Intellectual Property Handbook: Policy, Law and Use - Chapter 5: "International Treaties and Conventions on Intellectual Property", items 5.398-5.423 (WIPO Publication No. 489).

See: http://www.wipo.int/about-ip/en/iprm/.

20 "Basic Features to the Patent Law Treaty (PLT)" (prepared by the International Bureau; November 2006).

21 "Explanatory Notes on the Patent Law Treaty and Regulations under the Patent Law Treaty adopted by the Diplomatic Conference on June 1, 2000" (prepared by the International Bureau), Diplomatic Conference for the Adoption of the PLT, Document PT/DC/48 Prov. (November 2000), Note 11.01.

See http://www.wipo.int/meetings/en/details.jsp?meeting_id=4057. 
accord a filing date to an application on the basis of only three elements. These requirements are [Article 5(1)(a) PLT]:

(i) an indication that what is filed is intended to be a patent application;

(ii) indications identifying the applicant or allowing the applicant to be contacted; and

(iii) a part which on the face of it appears to be a description.

No additional element can be required for a filing date to be accorded. In particular, a PLT Contracting Party cannot require one or more claims as a filing date requirement. In addition, an applicant can file the description in any language [Article 5(2)(b) PLT], or replace the description and/or drawings by a reference to a previously filed application [Article 5(7) PLT]. A PLT Contracting Party may, for the purposes of the filing date, accept a drawing as the element referred to Article 5(1)(a)(iii) PLT [Article 5(1)(b) PLT].

The PLT also provides rules to establish a filing date where a part of the description or drawing is missing from the initially filed application. Normally, the filing of a missing part results in the accordance of a later filing date, i.e. the filing date becomes the date on which the missing part or missing drawing is filed [Article 5(6)(a) PLT]. However, if the application claims priority of an earlier application and the missing part or drawing is "completely contained" in the earlier application, the originally accorded filing date will be maintained [Article 5(6)(b) PLT].

\subsubsection{Discussed in this thesis}

The degree of alignment of the European Patent Convention (EPC 2000) and the Patent Cooperation Treaty (PCT) with the requirements of the PLT in relation to the requirements for according a date of filing, including the filing of an application by reference to a previously filed application as well as the filing of missing parts after the filing date of the application are the subject of Chapter II, III and IV of this thesis.

\subsection{Standardized application and forms}

A main feature of the Patent Law Treaty is that it provides standardized formality requirements for patent applications which are filed with a national or regional patent Office. Instead of defining these requirements again or differently in the PLT, it was decided to incorporate by reference the provisions of the Patent Cooperation Treaty (PCT) and its Regulations, wherever appropriate, into the PLT [Article 6(1) PLT]. In addition, the PLT provides for the establishment of several Model International Forms that have to be accepted by all Offices of PLT Contracting Parties [Article 6(2) and 8(3) PLT].

\subsubsection{Discussed in this thesis}

A discussion of the relationship between the PLT and the PCT, how, in preparation of the entry into force of the PLT, the PCT was amended in the spirit of the PLT and how future changes to the PCT are incorporated by reference in the PLT is given in Chapter IV of this thesis. 


\subsection{Simplified procedures before the Office}

"Simplification" is one of the keywords for the Patent Law Treaty. The PLT simplifies a number of procedures before the Office of PLT Contracting Parties during the processing of a patent application, as well as for the maintenance of a patent.

The PLT allows an Office of a PLT Contracting Party to require an applicant or owner to appoint a representative for the purposes of any procedure before the Office, except for certain procedures [Article 7(2) PLT]. In addition, an Office may only require the applicant to file evidence in support of the formal contents of an application, declarations of priority or the authentication of translations when the Office has a reasonable doubt as to the truthfulness of the indications or the accuracy of the translation submitted by the applicant [Article 6(6) PLT]. As regards a signature, a PLT Contracting Party may require evidence only where the Office has a reasonable doubt as to its authenticity [Article 8(4)(c) PLT].

A PLT Contracting Party may not require the applicant to file a copy or a certified copy of the earlier application or the previously filed application if such earlier application or previously filed application has been filed with the Office of that Contracting Party [Rule 4(3) PLT]. The same applies to cases where the Office could obtain the copy or the certification from other Offices through a digital library which is accepted by that Office for that purpose [Rule 4(3) PLT]. In addition, an Office may require a translation of the earlier application only where the validity of the priority claim is relevant to the determination of whether the invention concerned is patentable [Rule 4(4) PLT].

\subsubsection{Discussed in this thesis}

A discussion of the filing of certified copies of an earlier application and obtaining such copies from a digital library is given in Chapter VII of this thesis. Also see $\$ 3 \cdot 4 \cdot 4$.

The feature the PLT of appointing a representative or agent is not discussed in this thesis. Most PLT Contracting Parties have a less lenient practice than what is described by the PLT.

\subsection{Avoiding loss of rights}

Apart from the filing date requirements, one of the principal features of the Patent Law Treaty is that it prescribes procedures for the avoidance of unintentional loss of rights as a result of failure to comply with formality requirements. It can be regarded as a breakthrough of the PLT that for all these measures of relief, time limits with a duration of at least 2 months are specified.

\subsubsection{Relief in respect of time limits}

In principle, the PLT provides three types of relief procedures. The first is an extension of the time limit (for at least 2 months) where an applicant or owner requests the extension prior to the expiration of the time limit [Article 11(1)(i) PLT]. The second is an extension of 
the time limit (again for at least 2 months) where an applicant or owner requests the extension after the expiration of the unobserved time limit [Article 11(1)(ii) PLT]. The third remedy is the provision of continued processing [Article 11(2) PLT].

A PLT Contracting Party is not obliged to provide the first type of extension (extension prior to the expiration of the time limit). However, it is obliged to provide either the second type of extension (extension after the expiration of the time limit) or continued processing. Relief under these provisions is limited to non-compliance with a time limit fixed by the Office for an action in a procedure before the Office; it does not apply to time limits the duration of which is fixed in the law.

\subsubsection{Reinstatement of rights}

Another safeguard provision established by the PLT is the provision of reinstatement of rights if an applicant or owner fails to meet a time limit and, as a consequence, loses his rights with respect to an application or patent unintentionally or in spite of all due care required by the circumstances [Article $12 \mathrm{PLT}$ ]. The time limit to request reinstatement of rights shall not be less than 2 months from the date on which the reason of the non-compliance with the time limit is removed, or not less than 12 months from the expiration of the missed time limit, whichever is shorter [Rule 13(2) PLT]. In contrast to relief in respect of time limits, reinstatement of rights is applicable to all time limits, including time limits of which the duration is fixed in the law.

\subsubsection{Correction and addition of a priority claim}

The PLT provides for the possibility of addition and correction of priority claims for national/regional applications [Article 13 PLT]. This provision is copied into the PLT from the already existing provision in PCT Rule 26bis.1. ${ }^{22}$

\subsubsection{Restoration of the priority right}

Another safeguard provision established by the PLT is the provision of restoration of the priority right. There are two cases to be considered. In the first case, restoration of the priority right must be provided where an application is filed after the expiration of the 12-month priority period if the failure to claim priority within the Paris Convention period occurred in spite of all due care taken by the applicant or was unintentional [Article 13(2) $\mathrm{PLT}$ ]. The request for restoration including the filing of the application must be made within a time limit of at least 2 months from the date on which the priority period expired.

In the second case, restoration of the priority right must be provided where an applicant cannot submit a copy of an earlier application within 16 months from the priority date

22 PCT Rule 26bis.1 allowing an applicant to correct or add a priority claim, on or after the filing date, to an application which could have claimed the priority of an earlier application but did not do so, was introduced in the PCT on July 1, 1998. 
because of a delay in the Office with which the earlier application was filed [Article 13(3) PLT].

\subsubsection{Discussed in this thesis}

The degree of alignment of the European Patent Convention (EPC 2000) and the Patent Cooperation Treaty (PCT) with the requirements of the PLT in relation to relief in respect of time limits (extension of time limits and continued processing), the remedy of reinstatement of rights as well as the remedy of restoration of the priority right are the subject of Chapter V, VI and VII of this thesis.

\subsection{Paper and electronic communications}

One of the goals of the PLT is to facilitate the implementation of electronic filing of applications and other communications while, at the same time, not excluding any users from the benefits of the patent system, if they are not ready to apply electronic filing. In principle a PLT Contracting Party may, if it so wishes, exclude paper filing (i.e. the implementation of full electronic filing) with certain exceptions [Rule 8 PLT]. These exceptions are the obligation on all Offices to accord a filing date for a paper application [Article 5(1) PLT] and to accept the filing of communications on paper for the purpose of meeting a time limit [Article 8(1)(d) PLT].

\subsubsection{Not discussed in this thesis}

This feature of the PLT is not discussed in this thesis.

\section{Methodology}

The research methodology used in this thesis mainly consists of an analysis of the documents in relation to the negotiation history of the Patent Law Treaty. In particular, the reports and preparatory documents of the sessions of the Committee of Experts on the Patent Law Treaty in the period from December 1995 to December 1997, and the sessions of the Standing Committee on the Law of Patents (SCP) in the period from June 1998 to September 1999 have been studied. ${ }^{23-24}$ In addition, the Summary Minutes of the Main Committees during the Diplomatic Conference for the Adoption of the Patent Law Treaty held in Geneva in the period May-June 2000 have been studied. ${ }^{25}$ Where necessary, the documents in relation to the 1991 Diplomatic Conference for the adoption

${ }^{23}$ Committee of Experts on the Patent Law Treaty. See http://www.wipo.int/meetings/en/topic.jsp?group_id=53.

24 Standing Committee on the Law of Patents. See http://www.wipo.int/meetings/en/topic.jsp?group id=61\&items=30.

25 "Records of the Diplomatic Conference for the Adoption of the Patent Law Treaty (Geneva, 2000)", WIPO Publication No 327(E), pp. 262-568. 
of the "Treaty Supplementing the Paris Convention as far as Patents are Concerned" in The Hague were taken into account. ${ }^{26}$

The majority of the Travaux Préparatoires of the PLT is not directly available to the public. Some of the later preparatory documents are accessible and downloadable from web pages of the World Intellectual Property Organization (WIPO). However, the earlier versions of the "Draft PLT Articles and Draft Regulations" including the corresponding "Notes", "Reports" and other related documents can only accessed when requesting the WIPO to make them available.

With respect to the European Patent Convention (EPC), the Travaux Préparatoires of the Diplomatic Conference for the Revision of the EPC (EPC 2000) held in Munich in November 2000 were studied including the Special Editions of the Official Journal of the European Patent Office in relation to the Revised EPC. ${ }^{27}$

With respect to the Patent Cooperation Treaty (PCT), the documents relating to the Working Group on the Reform of the Patent Cooperation Treaty in the period from 2001 to 2007 were studied. ${ }^{30}$ Where necessary, the documents relating to the Sessions of the Assembly of the PCT Union were taken into account. ${ }^{31}$

Information has also been gathered by speaking with representatives of the Patent Law Section and the Patent Cooperation Treaty Legal Division of the World Intellectual Property Organization (WIPO) and with (former) representatives of the Directorate-General Legal/International Affairs of the European Patent Office. These conversations have been conducted off the record following the request of the persons involved not to be quoted in an explicit manner.

26 "Records of the Diplomatic Conference for the Conclusion of a Treaty Supplementing the Paris Convention as far as Patents are Concerned - Volume I: First Part of the Diplomatic Conference The Hague, 1991", WIPO Publication No. 351(E).

27 "Travaux Préparatoires of the Diplomatic Conference for the Revision of the European Patent Convention" (Munich 2000).

28 "Revision of the European Patent Convention (EPC 2000). Synoptic presentation EPC 1973/2000 - Part I: The Articles", EPO Official Journal 2007, Special Edition No. 4i comment in relation to Article 120 EPC.

See http://www.epo.org/patents/law/legal-texts/journal/2007.html.

29 "Revision of the European Patent Convention (EPC 2000). Synoptic presentation EPC 1973/2000 - Part II: The EPC Implementing Regulations", EPO Official Journal 2007, Special Edition No. 5; comment in relation to Rule $59 \mathrm{EPC}$.

See http://www.epo.org/patents/law/legal-texts/journal/2007.html.

30 Working Group on Reform of the PCT.

See http://www.wipo.int/meetings/en/topic.jsp?group id=133.

${ }^{11}$ International Patent Cooperation Union (PCT Union): Assembly. See http://www.wipo.int/meetings/en/topic.jsp?group id=135. 


\section{Negotiation history of the PLT}

Five sessions of the Committee of Experts on the Patent Law Treaty in the period from December 1995 to December 1997, ${ }^{32}$ and three sessions of the Standing Committee on the Law of Patents (SCP) in the period from June 1998 to September $1999{ }^{33}$ were held in Geneva to come to the "Basic Proposal" of the Patent Law Treaty and its Regulations which was presented to the Diplomatic Conference for the Adoption of the Patent Law Treaty in Geneva from May 11 to June 2, 2000.34-35

As indicated above, the original negotiations to come to a "Patent Law Treaty" (officially addressed as the "Treaty Supplementing the Paris Convention as far as Patents are Concerned"; $;{ }^{36}$ also addressed as the "Patent Harmonization Treaty") that would harmonize formal as well as substantive patent law stranded in January 1994 when the United States declared that it was unable to continue the discussions because of a lack of domestic support. ${ }^{37}$

In 1995, the World Intellectual Property Organization (WIPO) initiated another approach for promoting harmonization whereby only matters concerning the formality requirements of national and regional patent procedures would be covered..$^{38-39-40}$ Convened by the Director General following decisions made by the General Assembly of

32 Committee of Experts on the Patent Law Treaty. See http://www.wipo.int/meetings/en/details.jsp?meeting_id=3286.

33 Standing Committee on the Law of Patents. See http://www.wipo.int/meetings/en/topic.jsp?group_id=61\&items=30.

34 "Diplomatic Conference for the Adoption of the Patent Law Treaty". See http://www.wipo.int/meetings/en/details.jsp?meeting_id=4057. Many of the early documents are not electronically available but can, on request, be obtained from the WIPO.

35 "Records of the Diplomatic Conference for the Adoption of the Patent Law Treaty (Geneva, 2000)", WIPO Publication No $327(\mathrm{E})$.

36 "Records of the Diplomatic Conference for the Conclusion of a Treaty Supplementing the Paris Convention as far as Patents are Concerned - Volume I: First Part of the Diplomatic Conference The Hague, 1991", WIPO Publication No. 351(E).

37 On January 24, 1994, the International Bureau was informed, through a press release of the Department of Commerce of the United States of America, "that the United States would not seek to resume negotiations of a treaty harmonizing the world's patent laws at this time. While other international negotiations continue, we will maintain our first-to-invent system while keeping open the option of full patent harmonization in the future."

See "The Situation Concerning the Patent Law Treaty (PLT)" (memorandum of the International Bureau), Consultative Meeting for the further preparation of the Diplomatic Conference for the Conclusion of the Patent Law Treaty, Document PLT/CM/2 (March 1995), Item 7.

38 "Report" (adopted by the Assembly), Assembly of the International Union for the Protection of Industrial Property (Paris Union), Document P/A/XXII/2 (October 1994).

39 "The Situation Concerning the Patent Law Treaty $(P L T)$ " (memorandum of the International Bureau), Consultative Meeting for the further preparation of the Diplomatic Conference for the Conclusion of the Patent Law Treaty, Document PLT/CM/2 (March 1995).

40 "Report" (adopted by the Consultative Meeting), Consultative Meeting for the further preparation of the Diplomatic Conference for the Conclusion of the Patent Law Treaty, Document PLT/CM/4 (May 1995). 
WIPO and the Assembly of the Paris Union in their meetings of September/October $1995^{41-42}$ the Committee of Experts on the Patent Law Treaty held its first session in Geneva in December 1995. The meetings of the Committee were attended by representatives of States member of WIPO and/or the Paris Union. Representatives of the European Communities, the European Patent Office, the Organization of African Unity and the World Trade Organization as well as representatives of numerous non-governmental organizations took part in the sessions in an observer capacity.

During the meetings of the Committee of Experts on the Patent Law Treaty the Delegation of the United States repeated time after time "that it was still not in a position to discuss substantive patent law harmonization". ${ }^{43}$ In addition, the Delegation continuously expressed its concern about any requirement present in or introduced into the Draft PLT that could be regarded as a substantive requirement. By way of example, in the Draft PLT as presented at the second session of Committee of Experts on the Patent Law Treaty, there was a new Article on unity of invention [Article 6 and corresponding implementing Rule 6] which was regarded as "not appropriate for inclusion in this Treaty directed to formalities" as observed by the Delegation of the United States. ${ }^{44}$ In the Draft PLT as presented at the fourth session of the Committee of Experts on the Patent Law Treaty the Article on "unity of invention" was deleted.

In March 1998, the Assemblies of the Member States of WIPO and the Unions administered by WIPO approved a proposal for the establishment of "Standing Committees". ${ }^{45-46}$ The Standing Committee on the Law of Patents (SCP) became the successor of the Committee of Experts on the Patent Law Treaty. Because considerable progress had already been made, three sessions of the SCP (in June 1998, April 1999 and

${ }^{41}$ WIPO General Assembly, Meeting WO/GA/XVI (September 25 to October 3, 1995).

See http://www.wipo.int/meetings/en/details.jsp?meeting_id=2688. Documents are not electronically available.

42 International Union for the Protection of Industrial Property (Paris Union) Assembly, Meeting P/A/XXIII (September 25 to October 3, 1995).

43 See e.g. "Committee of Experts on the Patent Law Treaty-Report" (adopted by the Committee of Experts), Document PLT/CE/II/5 (June 1996), Item 12:

"The Delegation of the United States of America recalled its opening remarks made in the first session of the Committee of Experts and stated that it was still not in a position to discuss substantive patent law harmonization."

44 Ibid., Item 12: "The distinction between formal and substantive matters was important. In this regard, the Delegation expressed its concern over inclusion of the new Article on unity of invention as a substantive requirement that was not appropriate for inclusion in this Treaty directed to formalities."

45 "Assembly of the Member States of WIPO - General Report" (adopted by the Assemblies of the Member States), Document A/32/7 (March 1998).

See http://www.wipo.int/meetings/en/doc details.jsp?doc id=778.

46 "Organizational Matters and Overview of the Issues to be Considered by the Standing Committee on the Law of Patents" (Memorandum prepared by the International Bureau), Document $\mathrm{SCP} / 1 / 2$ (May 1998).

See http://www.wipo.int/meetings/en/details.jsp?meeting_id=3462. 
September 1999) were sufficient to convene a Diplomatic Conference in Geneva to conclude the Patent Law Treaty and the Regulations under the Patent Law Treaty (May 11 to June 2, 2000).

In this Chapter, aspects of the negotiation history will be described with respect to three subjects of the Patent Law Treaty. ${ }^{47}$ These are:

1) Requirements for the accordance of a filing date [Article 5 PLT].

The focus will be on the following three issues:

○ The basic requirements for according a filing date [Article 5(1) PLT];

- The filing date where a missing part of the description or a missing drawing is filed [Article 5(6) PLT];

- The filing of an application by reference to a previously filed application [Article 5(7) PLT].

2) Relief in respect of time limits including continued processing [Article $11 \mathrm{PLT}$ ] and reinstatement of rights after a finding of due care or unintentionality by the Office [Article 12 PLT].

3) Restoration of the priority right [Article 13(2) and (3) PLT].

None of the above subjects was present in the Draft PLT put before the Committee of Experts on the Patent Law Treaty at its first session in December 1995, although some of the later added provisions were modeled after texts in the Basic Proposal submitted to the 1991 Diplomatic Conference in The Hague. ${ }^{48}$

\subsection{Filing date requirements}

\subsubsection{Committee of Experts on the Patent Law Treaty}

In the "Draft Patent Law Treaty and Draft Regulations" prepared by the International Bureau and presented at the first session of the Committee of Experts on the Patent Law Treaty there was no article on requirements for accordance of a filing date. ${ }^{49}$ This was also noted in the corresponding "Notes" prepared by the International Bureau. ${ }^{50}$ In the "Report" adopted by the Committee of Experts, many Delegations favored, amongst

47 The selection of subjects is in line with the subjects studied in this thesis.

48 "Records of the Diplomatic Conference for the Conclusion of a Treaty Supplementing the Paris Convention as far as Patents are Concerned - Volume I: First Part of the Diplomatic Conference The Hague, 1991", WIPO Publication No. 351(E).

49 "Draft Patent Law Treaty and Draft Regulations" (prepared by the International Bureau), Committee of Experts on the Patent Law Treaty, Document PLT/CE///2 (October 1995).

50 "Notes" (prepared by the International Bureau), Committee of Experts on the Patent Law Treaty, Document PLT/CE/I/4 (October 1995), Item 2.01. 
other things, the inclusion in the PLT of provisions relating to requirements for the accordance of a filing date..$^{51}$

As a consequence a first draft of an Article 3 PLT "Filing Date" was presented before the Committee on its second session..$^{52}$ The text was modeled after Article 8 of the Basic Proposal submitted to the 1991 Diplomatic Conference in relation to the "Patent Harmonization Treaty". ${ }^{53}$ The filing date requirements contained 4 items:

Article 3(1) [Requirements]

(a) The filing date of the application shall be the date of receipt by the Office of a communication containing the following elements:

(i) an express or implicit indication to the effect that the communication is an application for a patent;

(ii) indications allowing the identity of the applicant to be established;

(iii) a description;

(iv) if the description is not in the language or in one of the languages of or admitted by the Office, an indication to the effect that the application contains a description.

In the corresponding "Notes" prepared by the International Bureau, it was remarked that Article 3 sets an international standard for the granting of a filing date. In that respect, Article 3 is different from other provisions of the Treaty, such as Article 2 PLT ("Application"), which establish a maximum list of allowed requirements. ${ }^{54}$ In the "Report" adopted by the Committee of Experts, many Delegations noted with satisfaction that the provisions on the filing date had been included. ${ }^{55}$ Several Delegations proposed that the payment of a filing fee should be a requirement for a filing date to be accorded; this proposal was rejected by a majority of Delegations. ${ }^{56}$ Several Delegations also suggested that the inclusion of claims should be a requirement for a filing date to be accorded. This suggestion was opposed by a majority of Delegations

51 "Report" (adopted by the Committee of Experts), Committee of Experts on the Patent Law Treaty, Document PLT/CE///5 (December 1995), see e.g. Items 14 (Canada), 27 (Switzerland), 37 (EPO) and 193 (Chairman).

52 "Draft Patent Law Treaty and Draft Regulations" (prepared by the International Bureau), Committee of Experts on the Patent Law Treaty, Document PLT/CE/II/2 (April 1996).

53 "Records of the Diplomatic Conference for the Conclusion of a Treaty Supplementing the Paris Convention as far as Patents are Concerned - Volume I: First Part of the Diplomatic Conference The Hague, 1991", WIPO Publication No. 351(E), Article 8 "Filing Date".

54 "Notes" (prepared by the International Bureau), Committee of Experts on the Patent Law Treaty, Document PLT/CE/II/3 (April 1996), Item 3.01.

55 "Report" (adopted by the Committee of Experts), Committee of Experts on the Patent Law Treaty, Document PLT/CE/II/5 (June 1996), see e.g. Items 15 (Switzerland), 16 (Canada), 28 (EPO).

${ }^{6}$ Ibid., Items 162-163. 
which were of the view that, although claims were necessary before a patent could be granted, it was not necessary to furnish them at the date of filing. ${ }^{57}$

The matter of the inclusion of claims, in line with PCT Article 11(1)(iii)(e), and the payment of a filing fee into the filing date requirements frequently popped up in later meetings of the Committee of Experts on the Patent Law Treaty and the Standing Committee on the Law of Patents, but the standard counterargument was that this provision had been well settled after lengthy discussions in the Committee..$^{58}$

In a later meeting of the Committee of Experts on the Patent Law Treaty, in response to a suggestion that, for conformity with PCT Article 11(1)(a)(iii), the words "express or implicit indication" be deleted from Article 3(1)(a)(i) PLT, the International Bureau explained that it was intended that this item be more liberal than the PCT. ${ }^{59}$

In the third session of the Committee of Experts on the Patent Law Treaty Article 3 PLT on "Filing Date" was renumbered to become Article 2 PLT. ${ }^{60}$ In addition, a new paragraph (4) was added to the Article allowing an applicant to replace the description and drawings by reference to another application from which priority is claimed; in addition, a certified copy of the earlier application must be furnished to the Office within a prescribed time limit. ${ }^{61}$ This provision was modeled after Article 8(4) of the Basic Proposal submitted to the 1991 Diplomatic Conference in relation to the "Patent Harmonization Treaty". ${ }^{62}$

In the subsequent "Report" adopted by the Committee of Experts, it was agreed that the paragraph on "filing by reference" would be maintained. ${ }^{63}$ Several Delegations suggested that the applicant should be required to furnish details concerning the date and country of filing of the previously filed application or even that the title of that application should be indicated. ${ }^{64}$ It was also suggested that the provision should not be

57 Ibid., Item 164 .

$5^{8}$ See e.g. "Draft Report" (prepared by the International Bureau), Standing Committee on the Law of Patents, Document SCP/1/7 (June 1998), Item 114.

See http://www.wipo.int/meetings/en/details.jsp?meeting_id=3462.

59 "Report" (adopted by the Committee of Experts), Committee of Experts on the Patent Law Treaty, Document PLT/CE/V/5 (December 1997), Item 65.

See http://www.wipo.int/meetings/en/details.jsp?meeting_id=3286.

6o "Selected Provisions of the Draft Patent Law Treaty and Draft Regulations" (prepared by the International Bureau), Committee of Experts on the Patent Law Treaty, Document $\mathrm{PLT} / \mathrm{CE} / \mathrm{III} / 2$ (September 1996).

61 Ibid., Article 2(4) PLT.

62 "Records of the Diplomatic Conference for the Conclusion of a Treaty Supplementing the Paris Convention as far as Patents are Concerned - Volume I: First Part of the Diplomatic Conference The Hague, 1991", WIPO Publication No. 351(E), Article 8 "Filing Date".

63 "Report" (adopted by the Committee of Experts), Committee of Experts on the Patent Law Treaty, Document PLT/CE/III/6 (November 1996), Item 63.

${ }^{64}$ Ibid., Item 64. 
restricted to those applications in respect of which priority is claimed. ${ }^{65}$ The Delegation of the United States of America suggested that the paragraph should provide for the electronic exchange of documents between Offices in place of submitting certified copies. ${ }^{66}$ The International Bureau explained that if the required certified copy of the previously filed application were not filed, the application containing a reference to that previously filed application would be considered as not having been filed. ${ }^{67}$ A Delegation observed that the term "description" in Article 2(4) did not include "drawings". ${ }^{68}$ In addition, it was suggested that not only a certified copy of the application referred to could be required, but also a translation where necessary. ${ }^{69}$ Eventually, most of the above suggestions were honored in the later versions of the Patent Law Treaty. In addition, the regulatory requirements relating to "filing by reference to a previously filed application" were moved to the Regulations under the PLT and, due to lack of agreement between the Delegations, contain a puzzling mix of compulsory requirements ("shall") and optional requirements which may be implemented as compulsory ("may require") by a PLT Contracting Party. ${ }^{70}$

In the meantime, the WIPO General Assembly and the Assembly of the Paris Union (meeting in September/October 1996) considering a Memorandum by the Director General in respect of Matters Concerning the Patent Law Treaty, decided, amongst others, to include filing date provisions in the draft Patent Law Treaty. ${ }^{71}$

In the fourth session of the Committee of Experts on the Patent Law Treaty Article 2 PLT on "Filing Date" was renumbered to become Article 4 PLT. ${ }^{72}$ The formulation "a description" in item (iii) of Article 4(1)(a) PLT of the requirements for accordance of a filing date was broadened to read: "a part which on the face of it appears to be a description"; this formulation is identical to the one in PCT Article 11(1)(iii)(d). In addition, in item ii of Article 4(1)(a) PLT, apart from "indications allowing the identity of the applicant ... to be established", a formulation was added "or allowing the applicant ... to be contacted by the Office". In the corresponding "Notes" prepared by the International Bureau, it was noted that whether the given indications are sufficient for "allowing the applicant ... to be contacted by the Office," as an alternative to "indications allowing the identity of the applicant ... to be established," would be a matter to be determined by the

65 Ibid., Item 65 .

66 Ibid., Item 66.

67 Ibid., Item 67.

68 Ibid., Item 68 .

69 Ibid., Item 69 .

70 See Rule 2(5) PLT: Requirements under Article 5(7)(a) PLT.

71 "Scope of the Patent Law Treaty" (Memorandum by the International Bureau), Committee of Experts on the Patent Law Treaty, Document PLT/CE/III/5 (October 1996).

72 "Draft Patent Law Treaty and Draft Regulations" (prepared by the International Bureau), Committee of Experts on the Patent Law Treaty, Document PLT/CE/IV/2 (April 1997). 
Office in the circumstances of that case. ${ }^{73}$ For example, where the application indicates the address without any name and there is only one resident at that address, the requirement of Article 4(1)(a)(ii) PLT would be regarded as having been complied with.

In the "Report" adopted by the Committee of Experts, a number of Delegations proposed that indications "allowing the applicant ... to be contacted by the Office" should not suffice for according a filing date. ${ }^{74}$ This proposal was opposed by other Delegations. Eventually, it was agreed that this item should be retained but that the International Bureau would reconsider the wording of the item and of the corresponding Notes in the light of the views expressed. ${ }^{75}$

In the Draft PLT, a new item (b) was added to Article 4(3) PLT (subsequent compliance with requirements) in relation to the late filing of drawings. If the applicant files missing drawings later on, the filing date would become the date on which the Office has received those drawings. Where these "later furnished drawings do not contain new matter" the original filing date may be retained. In the "Report", the International Bureau commented that the standard applied by a PLT Contracting Party in determining whether later furnished drawings contained "new matter" was a matter of substance. ${ }^{76}$ In the fifth session of the Committee of Experts on the Patent Law Treaty there were no substantial changes in Article 4 PLT on "Filing Date". ${ }^{77}$ A new item (c) was added to Article 4(3) PLT in relation to missing drawings and missing parts of the description, a provision according to which, where priority is claimed in the application, the contents of the priority document has to be taken into account in establishing whether correction by way of furnishing a missing part of the description or missing drawing should be allowed without loss of the initial filing date. ${ }^{78}$

73 "Notes" (prepared by the International Bureau), Committee of Experts on the Patent Law Treaty, Document PLT/CE/IV/3 (April 1997), Item 4.08.

74 "Report" (adopted by the Committee of Experts), Committee of Experts on the Patent Law Treaty, Document PLT/CE/IV/4 (June 1997), Item 53.

75 Ibid., Item 55 .

76 Ibid., Item 62.

77 "Draft Patent Law Treaty and Draft Regulations" (prepared by the International Bureau), Committee of Experts on the Patent Law Treaty, Document PLT/CE/V/2 (October 1997). See http://www.wipo.int/meetings/en/details.jsp?meeting_id=3286.

78 "Notes" (prepared by the International Bureau), Committee of Experts on the Patent Law Treaty, Document PLT/CE/V/3 (October 1997), Item 4.23.

See http://www.wipo.int/meetings/en/details.jsp?meeting_id=3286. 


\subsubsection{Standing Committee on the Law of Patents}

In the "Draft Patent Law Treaty and Draft Regulations" prepared by the International Bureau and presented at the first session of the Standing Committee on the Law of Patents Article 4(1) PLT was restricted to three items: ${ }^{79}$

Article 4(1) [Elements of Application]

(a) Subject to paragraphs (2) to (5), a Contracting Party shall provide that the filing date of an application shall be the date on which its Office has received all of the following elements, filed by means permitted by the Office:

(i) an express or implicit indication to the effect that the elements are intended to be an application;

(ii) indications allowing the identity of the applicant to be established or allowing the applicant to be contacted by the Office;

(iii) a part which on the face of it appears to be a description;

(b) A Contracting Party may provide that, for the purposes of the filing date, a drawing may replace the part referred to in subparagraph (a)(iii).

The language requirements which were previously listed in item (iv) of Article 4(1)(a) PLT were moved to paragraph 2 and reformulated:

Article 4(2) [Language]

(a) The indications referred to in paragraph (1)(a)(i) and (ii) may be required to be in a language accepted by the Office.

(b) The part referred to in paragraph (1)(a)(iii) may, for the purposes of the filing date, be in any language. Where the said part is not in a language accepted by the Office, the application shall contain an indication, in a language accepted by the Office, to the effect that the application contains a description.

The above formulations of the filing date requirements are already relatively close to the texts adopted during the Diplomatic Conference.

The reason for the introduction of new item (b) in Article 4(1) PLT can be inferred from discussions during the earlier meetings of the Committee of Experts on the Patent Law Treaty. In the Report of the third meeting in relation to item (iii) of Article 4(1) PLT, it was suggested by the International Bureau that the requirements for "a part which on the face of it appears to be a description" are to be interpreted more broadly. ${ }^{80}$ In particular, the term "description" could include disclosure through a drawing, an abstract or a sequence listing. It was suggested that the International Bureau would study whether the

79 "Draft Patent Law Treaty and Draft Regulations" (prepared by the International Bureau), Standing Committee on the Law of Patents, Document SCP/1/3 (April 1998).

See http://www.wipo.int/meetings/en/details.jsp?meeting_id=3462.

80 "Report" (adopted by the Committee of Experts), Committee of Experts on the Patent Law Treaty, Document PLT/CE/III/6 (November 1996), Item 54. 
item should be further amended in order to provide for the grant of a filing date in respect of an application containing only one or more drawings disclosing the invention but no written description. ${ }^{81}$ In the Report of the fourth meeting of the Committee, it was suggested by a number of Delegations to replace in item (iii) of Article 4(1)(a) PLT the formulation "description" by "disclosure" so that a filing date would be accorded where the invention was disclosed only in a drawing. ${ }^{82}$ Eventually, the formulation "description" was maintained because it was believed that applicants should not be encouraged to file applications without a description since any protection which would be obtained on the basis of a drawing alone would be very limited in many cases. ${ }^{83}$

In the "Notes" of the first session of the Standing Committee on the Law of Patents in relation to a drawing replacing the "part which on the face of it appears to be a description", the International Bureau remarked that any textual matter incorporated in that drawing may also be in any language. ${ }^{84}$ In the "Draft Report" of the first session of the Standing Committee on the Law of Patents, the Delegation of the United States of America expressed support for this provision, noting that it was in conformity with a recently litigated case in that country in respect of a design patent. ${ }^{85}$ Hence, the provision of item (b) was adopted with a minor textual modification.

In the "Draft Patent Law Treaty and Draft Regulations" presented at the first session of the Standing Committee on the Law of Patents, the provision permitting an applicant to replace the description and any drawings in an application by reference to a previously filed application in respect of the same invention was no longer restricted to references to applications from which priority is claimed but broadened to also cover references to any previously filed application by the same applicant or his predecessor in title [Article 4(7) PLT]. ${ }^{86}$

In the "Draft Patent Law Treaty and Draft Regulations" prepared by the International Bureau and presented at the second session of the Standing Committee on the Law of Patents, there were no substantial changes in Article 4 PLT on "Filing Date". ${ }^{87}$ Following

81 Ibid., Item 54 .

82 "Report" (adopted by the Committee of Experts), Committee of Experts on the Patent Law Treaty, Document PLT/CE/IV/4 (June 1997), Item 56.

83 Ibid., Item 56.

84 "Notes" (prepared by the International Bureau), Standing Committee on the Law of Patents, Document SCP/1/4 (April 1998), Item 4.13.

See http://www.wipo.int/meetings/en/details.jsp?meeting_id=3462.

85 "Draft Report" (prepared by the International Bureau), Standing Committee on the Law of Patents, Document SCP/1/7 Prov. 1 (June 1998), Item 116.

See http://www.wipo.int/meetings/en/details.jsp?meeting_id=3462.

86 "Notes" (prepared by the International Bureau), Standing Committee on the Law of Patents, Document SCP/1/4 (April 1998), Item 4.27.

87 "Draft Patent Law Treaty and Draft Regulations" (prepared by the International Bureau), Standing Committee on the Law of Patents, Document SCP/2/3 (February 1999).

See http://www.wipo.int/meetings/en/details.jsp?meeting_id=3713. 
a proposal by the Delegation of Australia with respect to the paragraph in Article 4 PLT in relation to the filing of missing parts of the description and missing drawings, and suggestions by the International Bureau based on this proposal, the formulation "the missing part of the description and the missing drawing ... do not contain new matter" in paragraph (5) of Article 4 PLT in relation to the filing of missing parts of the description and missing drawings, was replaced by "the missing part of the description or missing drawing be completely contained in the earlier application"; this formulation was incorporated in a new paragraph of the Rule regulating the details concerning the filing date requirements under Article 4 PLT. ${ }^{88-89}$ In the "Report" adopted by the Standing Committee on the Law of Patents, the Delegation of Australia explained that its concerns included, in particular, the high risk for an applicant when stating, in a declaration, that the missing part of the description or missing drawing in question included no new matter, and the need to preserve the contents of the earlier application of which the priority was claimed. ${ }^{90}$ As compared to the earlier formulation "no new matter", the check that a missing part of the description or a missing drawing is "completely contained" in the earlier application has the advantage that it can be carried out as a clerical check. ${ }^{91}$

In the "Draft Patent Law Treaty and Draft Regulations" prepared by the International Bureau and presented at the third session of the Standing Committee on the Law of Patents, Article 4 PLT on "Filing Date" and implementing Rule 2 PLT were "framed" indicating that the Article and Rule had been adopted by the Standing Committee. ${ }^{92}$ Two amendments are worth mentioning. The first one is that a new item was added to the requirements of Rule 2(4) PLT in relation to the situation where the applicant files missing parts of the description or missing drawings based on an earlier application from which priority is claimed [Article 4(6)(b) PLT], i.e. that "the application, at the time of filing, contained an indication that the contents of the earlier application were

88 "Draft Article 4(5bis) and draft Rule 2(2)" (Proposal by the Delegation of Australia), Standing Committee on the Law of Patents, Document SCP/2/9 (April 1999).

See http://www.wipo.int/meetings/en/details.jsp?meeting_id=3713.

89 "Draft Article 4(5bis) and draft Rule 2(2)" (Suggestion of the International Bureau, based on the Proposal by the Delegation of Australia in document SCP/2/9), Standing Committee on the Law of Patents, Document SCP/2/gbis (April 1999).

See http://www.wipo.int/meetings/en/details.jsp?meeting_id=3713.

90 "Report" (adopted by the Standing Committee), Standing Committee on the Law of Patents, Document SCP/2/13 (April 1999), Item 34 .

See http://www.wipo.int/meetings/en/details.jsp?meeting_id=3713.

91 "Notes" (prepared by the International Bureau), Standing Committee on the Law of Patents, Document SCP/3/3 (June 1999), Item R2.06.

See http://www.wipo.int/meetings/en/details.jsp?meeting_id=3824.

92 "Draft Patent Law Treaty and Draft Regulations" (prepared by the International Bureau), Standing Committee on the Law of Patents, Document SCP/3/2 (June 1999).

See http://www.wipo.int/meetings/en/details.jsp?meeting_id=3713. 
incorporated by reference in the application". ${ }^{93}$ The second one is that in Article 4(6)(b) PLT relating to the situation where the applicant files missing parts of the description or missing drawings based on an earlier application from which priority is claimed, the words "at the time of filing" were replaced by the words "at the date on which one or more elements referred to in Article 4(1)(a) were first received by the Office" ${ }^{.94}$

\subsubsection{Diplomatic Conference for the Adoption of the PLT}

In the Draft Proposal submitted to the Diplomatic Conference for the Adoption of the Patent Law Treaty submitted by the Director General of WIPO, Article 4 PLT on "Filing Date" was renumbered to become Article 5 PLT. ${ }^{95}$

Issues relevant for the Draft Patent Law Treaty were discussed at a session of the PCT Assembly held in March 2000; these issues were summarized in a document submitted for consideration to the PLT Diplomatic Conference. ${ }^{96}$ In relation to the filing date requirements, it was suggested that a discussion should take place at the Diplomatic Conference on the question of amending draft Article 5(1) PLT, perhaps in a general way or subject to future amendments of the Regulations, in order to allow applicants to obtain a filing date using future technologies. ${ }^{97}$

During the meetings at the Diplomatic Conference for the Adoption of the Patent Law Treaty the filing date requirements were extensively discussed. The Delegation of the United States of America proposed that, under Article 5(1)(a) PLT, the only item that be required for the establishment of a filing date should be item (iii), namely "a part which on the face of it appeared to be a description"; the Delegation felt strongly that the filing date provisions should be a minimum, that it should be readily obtained by applicants and that any concerns relating to current items (i) and (ii) should not be determinative of the filing date..$^{98}$ In its comment, the Japanese Delegation referred to the negotiation history of the PLT: the hard-line for negotiating the Treaty was the harmonization of

93 "Notes" (prepared by the International Bureau), Standing Committee on the Law of Patents, Document SCP/3/3 (June 1999), Item R2.07 (proposal by the Delegation of the United States of America).

94 Ibid., Item 27 (proposal by the Delegation of the Russian Federation).

95 "Basic Proposal for the Patent Law Treaty" (submitted by the Director General of WIPO), Diplomatic Conference for the Adoption of the Patent Law Treaty, Document PT/DC/3 (November 1999).

See http://www.wipo.int/meetings/en/details.jsp?meeting_id=4057.

96 "Results of the $28^{\text {th }}$ ( $16^{\text {th }}$ Extraordinary) Session of the PCT Assembly, March 13 to 17, 2000; Issues for possible Discussion at the Diplomatic Conference" (prepared by the International Bureau), Diplomatic Conference for the Adoption of the Patent Law Treaty, Document PT/DC/6 (April 2000).

See http://www.wipo.int/meetings/en/details.jsp?meeting_id=4057.

97 Ibid., Item 33.

98 Summary Minutes of the Main Committee I (prepared by the International Bureau); $9^{\text {th }}$ session (Friday, May 19, 2000, morning); published in Records of the Diplomatic Conference for the Adoption of the Patent Law (Geneva, 2000) (WIPO Publication 327E), Item 701. 
procedural issues as much as possible, and, among the issues to be harmonized, the filing date was the most important element. ${ }^{99}$ The Japanese Delegation felt deep concern about too flexible procedures for obtaining a filing date. Article 5(1)(a) PLT as it was presently drafted provided that all three of these elements must be submitted for an application to be given a filing date, which was an indispensable factor to harmonize a minimum and a maximum requirement for the establishment of the filing date. The filing date had a quite essential legal effect for the patent application. From a legal point of view, an action by a person took legal effect only if the intention of the action was defined and the identity of the person was clear. The same rule should apply in this case, therefore, the legal effect for the filing date should require items (i) and (ii) of Article 5(1)(a) PLT. ${ }^{100}$ Of course, the issue of adding a fourth item: "(iv) a part which on the face appears to a claim or claims" was brought up and rejected (again). ${ }^{101}$

It was observed by a representative of the World Intellectual Property Organization, that PCT Article 11(1) was also relevant since the PCT was the starting point for the provision on the filing date in Article 5(1) PLT. ${ }^{102}$ The drafting of the PLT had closely followed the $P C T$, although in some cases, it had been deemed that the PLT should be more user-friendly. In PCT Article 11(1), there were seven requirements for according a filing date under the PCT. Two of those requirements would not apply to national filings because they dealt with residency requirements and the designation of a PLT Contracting State. Of the remaining five, three corresponded to items in the PLT. There were two remaining items in the filing date requirements for the PCT where the PLT was more liberal, namely the inclusion of claims and the language requirements. ${ }^{103} \mathrm{~A}$ Representative of the European Patent Organization said that Article 5(1) PLT was perhaps the most important provision in the draft PLT, since it established a uniform worldwide standard; any possible deviation from this standard, including the possibility for national Offices to require a fee, should be avoided. ${ }^{104}$ Eventually, the three items of Article 5(1)(a) PLT for establishing a filing date were maintained as proposed.

In addition, the language requirements in Article 5(2) PLT were adopted in relation to the languages in which the three items of Article 5(1)(a) PLT can be filed. ${ }^{105}$ It was observed by a representative of the World Intellectual Property Organization that the possibility of

99 Ibid., Item 706.

${ }^{100}$ Ibid., Item 706.

${ }^{101}$ Ibid., Item 705.

${ }^{102}$ Ibid., Item 718.

${ }^{103} \mathrm{Ibid}$. Item 718.

104 Summary Minutes of the Main Committee I (prepared by the International Bureau); $10^{\text {th }}$ session (Friday, May 19, 2000, afternoon); published in Records of the Diplomatic Conference for the Adoption of the Patent Law (Geneva, 2000) (WIPO Publication 327E), Item 731.

${ }^{105}$ Summary Minutes of the Main Committee I (prepared by the International Bureau); $11^{\text {th }}$ session (Friday, May 19, 2000, evening); published in Records of the Diplomatic Conference for the Adoption of the Patent Law (Geneva, 2000) (WIPO Publication 327E), Item 811. 
filing the description of an application in any language was one of the key issues of the draft PLT. ${ }^{106}$

Article 5(3) PLT relating to the Office notifying the applicant where one or more of the requirements in Article 5(1) and (2) PLT are not complied with, and Article 5(4) PLT relating to the subsequent compliance with the requirements in Article 5(1) and (2) PLT, were adopted without much discussion. ${ }^{107}$

With respect to Article 5(5) PLT relating to the notification concerning a missing part of the description or a missing drawing, a representative of the World Intellectual Property Organization emphasized that an Office would not be required to make any special check for missing descriptions or drawings; also, Article 5(5) PLT did not apply where the Office discovered the omission in a different procedure, for example in the course of substantive examination. ${ }^{108}$ With regard to Article 5(6) PLT relating to the situation where the missing part of the description or the missing drawing was filed subsequently, the representative of the World Intellectual Property Organization pointed out that the filing date would, under Article 5(6)(a) PLT, be the date on which the missing part of the description or drawing was received by the Office, whereas Article 5(6)(b) and (c) PLT addressed two situations in which the earlier date of receipt of the incomplete application could be preserved as the filing date. ${ }^{109}$ Article 5(5) and (6) PLT were meant to give an applicant the opportunity to file missing parts as quickly as possible in order to minimize the loss of filing date. ${ }^{110}$ After discussion, Article 5(5) and Article 5(6) PLT were adopted in substance. ${ }^{111}$

With respect to Article 5(7) PLT allowing an applicant to replace the description or the drawings by a reference to an earlier application, a representative of the World Intellectual Property emphasized that it is a very user-friendly provision. ${ }^{112}$ The representative of the Institute of Professional Representatives before the European Patent Office (epi) said that filing by reference would particularly be beneficial for small applicants who had to file in the last minute before the expiration of the priority period, and who were not interested in applying in a great number of countries, and therefore did not want to incur the cost of a PCT application. ${ }^{113}$ The Delegation of Japan recalled

${ }^{106}$ Ibid., Item 806.

107 Summary Minutes of the Main Committee I (prepared by the International Bureau); $19^{\text {th }}$ session (Wednesday, May 24, 2000, evening); published in Records of the Diplomatic Conference for the Adoption of the Patent Law (Geneva, 2000) (WIPO Publication 327E), Items 1845 and 1854, respectively.

108 Ibid., Item 1861.

${ }^{109}$ Ibid., Item 1861.

110 Ibid., Item 1867.

${ }^{111}$ Ibid., Items 1905, 1910 and 1938, respectively.

${ }^{112}$ Summary Minutes of the Main Committee I (prepared by the International Bureau); $20^{\mathrm{h}}$ session (Thursday, May 25, 2000, morning); published in Records of the Diplomatic Conference for the Adoption of the Patent Law (Geneva, 2000) (WIPO Publication 327E), Item 1944.

${ }^{113}$ Ibid., Item 1960. 
that, while Article 5(1) PLT provided for the indispensable three elements for establishing the filing date of an application, the reference procedure in Article 5(7) PLT provided for an exception to this principle by enabling Offices to grant a filing date even when not all three elements had being received by the Office and proposed to add further restrictions. ${ }^{114}$ After lengthy discussions and some amendments Article 5(7) PLT and the corresponding Rule were adopted in substance. ${ }^{115}$

Article 5(8) PLT relating to "exceptions" was adopted without much discussion. ${ }^{116}$

\subsection{Relief in respect of time limits}

\subsubsection{Committee of Experts on the Patent Law Treaty}

In the "Draft Patent Law Treaty and Draft Regulations" prepared by the International Bureau and presented at the first session of the Committee of Experts on the Patent Law Treaty there was no article on relief in respect of time limits. ${ }^{117}$ In the "Report" adopted by the Committee of Experts, a number of Delegations favored, amongst other things, the inclusion in the PLT of provisions relating to the extension of specific time limits. ${ }^{118}$ In the "Draft Patent Law Treaty and Draft Regulations" prepared by the International Bureau and presented at the second session of the Committee of Experts on the Patent Law Treaty there also was no article on relief in respect of time limits. ${ }^{119}$ In the "Report" adopted by the Committee of Experts, the Japanese Delegation advocated, amongst other things, the inclusion in the PLT of provisions relating to the extension of specific time limits and the restoration of rights after a missed time limit. ${ }^{120}$ After a full discussion, the Committee of Experts agreed to recommend that two additional topics should be included in the next draft of the PLT including restoration of rights where a time limit had been missed (including "further processing") and extension of time limits which had not yet expired but whose extension was requested by the party concerned. ${ }^{121}$ In the "Draft Patent Law Treaty and Draft Regulations" prepared by the International Bureau and presented at the third session of the Committee of Experts on the Patent Law

\footnotetext{
${ }^{114}$ Ibid., Item 1946.

${ }^{115}$ Ibid., Item 2052.

${ }^{116}$ Ibid., Item 2006.

117 "Draft Patent Law Treaty and Draft Regulations" (prepared by the International Bureau), Committee of Experts on the Patent Law Treaty, Document PLT/CE/I/2 (October 1995).

118 "Report" (adopted by the Committee of Experts), Committee of Experts on the Patent Law Treaty, Document PLT/CE/I/5 (December 1995), Items 46 (Japan), 205 (France and AIPPI).

119 "Draft Patent Law Treaty and Draft Regulations" (prepared by the International Bureau), Committee of Experts on the Patent Law Treaty, Document PLT/CE/II/2 (April 1996).

120 "Report" (adopted by the Committee of Experts), Committee of Experts on the Patent Law Treaty, Document PLT/CE/II/5 (June 1996), Items 16 (Canada) and 33 (Japan Patent Attorneys Association).

${ }^{121}$ Ibid., Item 276.
} 
Treaty there was a new Article 12 PLT "Extension of a time limit". ${ }^{122}$ Article 12 PLT sets a minimum of rights a Contracting Party shall extend to an applicant or owner in respect of a request for an extension of a time limit. It is to be noted that this Article deals with the time limit for an action before the Office, and not the time limit before a court. ${ }^{123}$ Article 12(1) PLT addresses the situation in which an applicant or owner requests the extension of a time limit before that time limit has expired. However, in accordance with subparagraph (c), the term does not include the submission of a priority claim for which a new Article 13 PLT (belated claiming of priority) was introduced. An Office would not be permitted to impose any payment of a fee for the first extension of the time limit. ${ }^{124}$ Article 12(2) PLT addresses the situation in which an applicant or owner requests the extension of a time limit after that time limit has expired. Subparagraph (b) is intended to prevent that an applicant or owner loses rights attached to his application or other communication because of a failure to meet a time limit if he has taken all due care required by the circumstances to comply with the time limit. ${ }^{125}$

In the meantime, the WIPO General Assembly and the Assembly of the Paris Union (meeting in September/October 1996) considering a Memorandum by the Director General in respect of Matters Concerning the Patent Law Treaty, decided, amongst others, to include provisions relating to restoration of rights where a time limit has been missed (including "further processing") and extension of time limits which have not yet expired but whose extension has been requested by the party concerned. ${ }^{126}$

In the "Report" adopted by the Committee of Experts of the third session, many Delegations and representatives of intergovernmental and non-governmental organizations supported the principle of harmonization of extension of time limits expressed in Article 12 PLT. ${ }^{127}$ However, several Delegations expressed the view that it was necessary to differentiate between time limits established by law or convention and those established by the Office. By way of example, several Delegations observed that the time limit for the payment of fees for the maintenance of industrial property rights should not be extensible beyond what was prescribed by Article 5 bis of the Paris Convention. ${ }^{128}$ The Delegation of Germany indicated that the Patent Law Committee of the European Patent Organization had considered the matter and had expressed the view that distinctions should be made between a time limit established by law or convention

\footnotetext{
122 "Draft Patent Law Treaty and Draft Regulations" (prepared by the International Bureau), Committee of Experts on the Patent Law Treaty, Document PLT/CE/III/2 (September 1996).

123 "Notes" (prepared by the International Bureau), Committee of Experts on the Patent Law Treaty, Document PLT/CE/III/3 (September 1996), Item 12.01.

124 Ibid., Item 12.02.

125 Ibid., Item 12.05 .

126 "Scope of the Patent Law Treaty" (Memorandum by the International Bureau), Committee of Experts on the Patent Law Treaty, Document PLT/CE/III/5 (October 1996).

127 "Report" (adopted by the Committee of Experts), Committee of Experts on the Patent Law Treaty, Document PLT/CE/III/6 (November 1996), Item 159.

${ }^{128}$ Ibid., Item 167.
} 
and a time limit established by an Office and, as regards the latter kind of time limits, between an extension before the time limit had expired and an extension after the expiration of the time limit. As regards the time limits established by law or convention, there should only be the possibility of re-establishment of rights for special reasons whereas, for the time limits fixed by an Office, there would be the possibility of requesting an extension (further processing) without such reasons. ${ }^{129}$

In the "Draft Patent Law Treaty and Draft Regulations" prepared by the International Bureau and presented at the fourth session of the Committee of Experts on the Patent Law Treaty, Article 12 PLT was renumbered to become Article 13 PLT and new Article 14 PLT was introduced. ${ }^{130}$ Article 12 PLT sets a minimum of rights a PLT Contracting Party must extend to an applicant or owner in respect of a request for an extension of a time limit established by the Office whereas the extension of time limits established by national legislation or regional treaty is regulated by Article 14 PLT. ${ }^{131}$ Article 12(1) PLT addresses the situation in which an applicant or owner requests the extension of a time limit established by the Office before that time limit has expired whereas Article 12(2) PLT addresses the situation in which an applicant or owner requests the extension of a time limit established by the Office after that time limit has expired. ${ }^{132}$ Article 14 PLT sets a minimum of rights a PLT Contracting Party must extend to an applicant or owner concerned in respect of a request for an extension of a time limit established by national legislation or under a treaty providing for the grant of regional patents. Except in respect of intervening rights [Article 14(5) PLT], any PLT Contracting Party would be free to be more liberal in granting such an extension. As in the case of Article $13 \mathrm{PLT}$, it was be noted that Article 14 PLT deals with the time limit for an action before the Office, and not the time limit before a court. ${ }^{133}$

In the "Report" adopted by the Committee of Experts it was agreed, after some discussion, that Article 12(2) PLT related to restoration, not extension, and should be transferred to Article 14 PLT. ${ }^{134}$ In addition, a proposal by the Delegation of the United States of America that the concept "in spite of due care required by the circumstances" be replaced by the concept "the failure to comply was unintentional" was approved. ${ }^{135}$

\footnotetext{
129 Ibid., Item 168.

130 "Draft Patent Law Treaty and Draft Regulations" (prepared by the International Bureau), Committee of Experts on the Patent Law Treaty, Document PLT/CE/IV/2 (April 1997).

131 "Notes" (prepared by the International Bureau), Committee of Experts on the Patent Law Treaty, Document PLT/CE/IV/3 (April 1997), Item 13.01.

132 Ibid., Items 13.02 and 13.05 .

133 Ibid., Item 14.01.

134 "Report" (adopted by the Committee of Experts), Committee of Experts on the Patent Law Treaty, Document PLT/CE/IV/4 (June 1996), Item 189.

135 "Report" (adopted by the Committee of Experts), Committee of Experts on the Patent Law Treaty, Document PLT/CE/IV/4 (June 1996), Item 190.
} 
In the "Draft Patent Law Treaty and Draft Regulations" prepared by the International Bureau and presented at the fifth session of the Committee of Experts on the Patent Law Treaty the wording "a time limit established by the Office" in Article 13 PLT was replaced by "a time limit fixed by the Office"; in addition, Article ${ }_{4}$ PLT was given a new title "further processing; restoration of rights" and the content was adapted accordingly. ${ }^{136}$

Relief in the form of "further processing" or restoration of rights may be available in the case where the time limit to request extension of a time limit has expired. ${ }^{137}$ In particular, Article 14(1)(a) PLT was introduced following the approval by the previous session of the Committee of Experts that a proposal providing for "further processing" should generally be permitted on the mere basis of a request and the payment of a fee. ${ }^{138}$ Further processing under this provision would be restricted to the cases in which an application is to be, or has been, refused or considered withdrawn or abandoned following failure to comply with a time limit fixed by the Office for an action before the Office. ${ }^{139}$ This provision therefore does not apply where the time limit which was not complied with is established by national legislation or under a treaty providing for the grant of regional patents. It also does not apply where the failure to comply with the time limit does not result directly in the loss of the application. It also does not apply in the case of a granted patent, in which case relief may be available by way of restoration of rights under Article 14(2) PLT, or where any maximum time limit established by law for the fixing of the time limit by the Office has expired. However, this provision would apply irrespective of whether or not the failure to comply with the time limit occurred in spite of all due care required by the circumstances having been taken or was unintentional. ${ }^{140}$

In the "Report" adopted by the Committee of Experts, the Representative of the European Patent Organization explained that it was intended to extend further processing under the European Patent Convention (in view of the EPC 2000 Revision) to non-compliance with time limits established under that Convention. ${ }^{141}$ Accordingly, it was agreed that the International Bureau would revise the corresponding provisions.

\subsubsection{Standing Committee on the Law of Patents}

In the "Draft Patent Law Treaty and Draft Regulations" prepared by the International Bureau and presented at the first session of the Standing Committee on the Law of

\footnotetext{
136 "Draft Patent Law Treaty and Draft Regulations" (prepared by the International Bureau), Committee of Experts on the Patent Law Treaty, Document PLT/CE/IV/2 (April 1997).

137 "Notes" (prepared by the International Bureau), Committee of Experts on the Patent Law Treaty, Document PLT/CE/V/3 (October 1997), Item 13.05.

See http://www.wipo.int/meetings/en/details.jsp?meeting_id=3286.

${ }^{138}$ Ibid., Item 14.01.

139 Ibid., Item 14.02.

${ }^{140} \mathrm{Ibid}$. Item 14.02.

141 "Report" (adopted by the Committee of Experts), Committee of Experts on the Patent Law Treaty, Document PLT/CE/V/5 (December 1997), Item 213.

See http://www.wipo.int/meetings/en/details.jsp?meeting_id=3286.
} 
Patents, Article 13 PLT ("Extension of a time limit fixed by the Office") was restricted to requests for extension of a time limit fixed by the Office for an action in a procedure before the Office prior to the expiration of that time limit. ${ }^{142}$ Article 13(1) PLT provides for the extension of a time limit as of right. In particular, the applicant or owner concerned could not be required to state the grounds on which the request is based. ${ }^{143}$ Article 14 PLT provides that "further processing" of an application should generally be permitted on the mere basis of a request and the payment of a fee ${ }^{144}$ In addition, in response to a suggestion by the Delegation of the United States of America at the fifth session of the Committee of Experts, Article 14 PLT permits for revival of an application as an alternative to further processing. ${ }^{145}$ The words "fixed by the Office" in Article 14(1)(a) PLT were placed in square brackets for consideration by the Standing Committee as to whether this paragraph should be restricted to time limits fixed by the Office or whether it should apply also to time limits established by national legislation or under a treaty providing for the grant of regional patents, as proposed by the representative of the European Patent Office at the fifth session of the Committee of Experts. ${ }^{146}$ In contrast to restoration of rights, a Contracting Party would not be permitted to restrict further processing to those cases in which the failure to comply with the time limit occurred in spite of all due care or was unintentional, so that there would be no requirement for a declaration or other evidence in this respect. ${ }^{147}$

Article 15 PLT provides for the restoration of rights in respect of an application or patent following failure to comply with a time limit for an action before the Office. However, restoration would be restricted to those situations in which the failure of the time limit occurred in spite of all due care required by the circumstances or was unintentional [Article 15(1)(iii) PLT]. ${ }^{148}$ Accordingly, as in the case of existing national and regional legislation, the standard applied in respect of restoration of rights would generally be substantially higher than the case of further processing, where no such requirements would be permitted, or in the case of revival of rights where, under Article 14(1)(b) PLT, only a "statement" would be required. ${ }^{149}$ In addition, in contrast to further processing or revival under Article ${ }_{14}$ PLT, restoration of rights would not be restricted to time limits in respect of applications; it would also not be restricted to time limits fixed by the Office.

\footnotetext{
${ }_{142}$ "Draft Patent Law Treaty and Draft Regulations" (prepared by the International Bureau), Standing Committee on the Law of Patents, Document SCP/1/3 (April 1998).

See http://www.wipo.int/meetings/en/details.jsp?meeting_id=3462.

143 "Notes" (prepared by the International Bureau), Standing Committee on the Law of Patents, Document SCP/1/4 (April 1998), Item 13.02.

See http://www.wipo.int/meetings/en/details.jsp?meeting_id=3462.

$144 \mathrm{Ibid}$., Items 14.01 and 14.10.

${ }^{145}$ Ibid., Item 14.01.

${ }_{146}$ Ibid., Item 14.04.

147 Ibid., Item 14.10.

${ }_{148} \mathrm{Ibid}_{\text {., Item } 15.01 .}$

149 Ibid., Item 15.01.
} 
In the "Draft Report" of the first session of the Standing Committee on the Law of Patents, a suggestion was made to combine Articles 14 and ${ }_{15} \mathrm{PLT} .{ }^{150}$ Following the discussions, a "Revised Text of Provisions" including comments was prepared for further study. ${ }^{151}$ In this document the title of Article 14 PLT "Further Processing or Revival of Application" was replaced by "Continued Processing and/or Re-instatement of Application [or Patent] Without a Finding of Due Care by the Office". In addition, the title of Article 15 PLT "Restoration of Rights" was replaced by "Re-instatement of Application or Patent After a Finding of Due Care by the Office". Article 14(1) PLT refers to any situation where an applicant (or owner) fails to comply with a time limit fixed by the Office. ${ }^{152}$ In the "Report" of the first session (second part) of the Standing Committee on the Law of Patents, it was suggested to move the provisions concerning reinstatement under Article 14 PLT to Article 15 PLT, so that Article 14 PLT would concern only further processing, not requiring intervening rights, and Article 15 PLT would concern all reinstatement of rights. ${ }^{153}$

In the "Draft Patent Law Treaty and Draft Regulations" prepared by the International Bureau and presented at the second session of the Standing Committee on the Law of Patents, Articles 13, 14, 15 and 16 PLT were renumbered to become Articles 10, 11, 12 and 13 PLT, respectively. ${ }^{154}$ In the corresponding "Notes" the distinction between Articles 10,11, 12 and 13 PLT was explained by the International Bureau: ${ }^{155}$

- Article 10 PLT provides for the extension of a time limit as of right, where the request for such extension is made before the expiration of that time limit. It is limited to the extension of time limits fixed by the Office for an action in a procedure before the Office and is subject only to the payment of a fee.

Accordingly, the applicant or owner concerned could not be required to state the grounds on which the request under Article $10 \mathrm{PLT}$ is based. ${ }^{156}$

150 "Draft Report" (prepared by the International Bureau), Standing Committee on the Law of Patents, Document SCP/1/7 Prov. 1 (June 1998), Item 161.

See http://www. wipo.int/meetings/en/details.jsp?meeting_id=3462.

151 "Revised Text of Provisions referred to the International Bureau for Further Study" (prepared by the International Bureau), Standing Committee on the Law of Patents, Document SCP/1/8 (October 1998).

See http://www.wipo.int/meetings/en/details.jsp?meeting_id=3611.

${ }_{152}$ Ibid., p. 25: Commentary on suggested changes to draft to Article 14(1) PLT.

153 "Report" (prepared by the International Bureau), Standing Committee on the Law of Patents, Document SCP/1/11 (December 1998), Item 185.

See http://www.wipo.int/meetings/en/details.jsp?meeting_id=3611.

154 "Draft Patent Law Treaty and Draft Regulations" (prepared by the International Bureau), Standing Committee on the Law of Patents, Document SCP/2/3 (February 1999).

See http://www.wipo.int/meetings/en/details.jsp?meeting_id=3713.

155 "Notes" (prepared by the International Bureau), Standing Committee on the Law of Patents, Document SCP/2/4 (February 1999), Item 10.01.

See http://www.wipo.int/meetings/en/details.jsp?meeting_id=3713.

${ }^{156}$ Ibid., Item 10.01. 
- In contrast, Articles 11 and 12 PLT apply where the request for relief is made after the expiration of the time limit concerned. Article 11 PLT provides for the Office to consider the time limit to have been complied with, and to continue processing and re-instate any rights with respect to the application [or patent], subject only to the payment of a fee, provided that the request is filed, and the requirements in respect of which the time limit applied are complied with in due time. ${ }^{157}$ As in the case of Article 10 PLT, Article 11 PLT is limited to the extension of time limits fixed by the Office for an action in a procedure before the Office.

- As in the case of Article 11, Article 12 PLT provides for the re-instatement of rights where the request is made after the expiration of the time limits concerned. In contrast to Article 11 PLT, Article 12 PLT is not restricted to time limits fixed by the Office but applies to any time limit in respect of which failure to comply has the direct consequence of causing a loss of rights with respect to the application or patent concerned. ${ }^{158}$

- Article 13 PLT provides for the addition of a priority claim [Article 13(1) PLT]. In addition, Article 13 PLT provides for the restoration of a priority claim in the case of the delayed filing of the subsequent application [Article 13(2) PLT] or the failure to furnish a copy of the earlier application within the prescribed time limit [Article 13(3) PLT]. In order to avoid the possibility of double relief, the time limits referred to in Article 13(1), (2) and (3)(a) PLT are expressly excluded in the exceptions under Articles 10 to 12 PLT. ${ }^{159}$

Each of Articles 10 to 13 PLT sets the maximum standard which a PLT Contracting Party may apply. A PLT Contracting Party would be permitted, but not obliged, to dispense with any requirement under these Articles, or to apply any requirement or provide any relief which, from the viewpoint of applicants, owners or other interested persons, is more favorable than the requirements or relief prescribed in these Articles and associated Regulations. ${ }^{160}$

In preparation for the second session of the Standing Committee on the Law of Patents, the Delegation of the United States submitted a proposal for a revised text of the Articles 10 to 12 PLT. ${ }^{161}$ This proposal was based on the Delegation's preference to continue the present system in its country, under which the vast majority of requests for extension of time limits are filed after the expiration of the time limit, but before the expiration of the extension period, and must be accompanied by the requirements

\footnotetext{
157 Ibid., Item 10.02.

${ }^{158}$ Ibid., Item 10.03 .

159 Ibid., Item 10.04

${ }^{160}$ Ibid., Item 10.05

161 "Draft Article 10 to 12 and Draft Rules 12 to 14" (prepared by the Delegation of the United States of America), Standing Committee on the Law of Patents, Document SCP/2/8 (April 1999). See http://www.wipo.int/meetings/en/details.jsp?meeting_id=3713.
} 
needed to comply with the original time limit. ${ }^{162}$ The Delegation of the United States considered this procedure to be user-friendly, and to reduce the administrative burden on the Office. However, the Delegation of Germany, supported by other Delegations, proposed that Articles 10 to 12 PLT and the related Rules be retained. These Delegations emphasized that users were familiar with the practice of submitting requests for extension of a time limit prior to the expiration of the time limit, and referred to the need for a clear distinction between the procedures under Articles 10 and $11 \mathrm{PLT} .{ }^{163} \mathrm{In}$ addition, the Representative of the European Patent Organization, supported by other Representatives, emphasized that Articles 10 to 12 PLT were important provisions for applicants, and that extensions under Article 10 PLT should be retained and be distinguished from reinstatement of rights under Articles 11 and 12 PLT. ${ }^{164}$

In the "Draft Patent Law Treaty and Draft Regulations" prepared by the International Bureau and presented at the third session of the Standing Committee on the Law of Patents, Article 10 PLT ("relief in respect of the non-compliance with a time limit") was reformulated to provide for relief in respect of the non-compliance with a time limit fixed by the Office with regard to an application or a patent, without specifying the form of relief. ${ }^{165}$ In particular, Article 10 PLT does not distinguish between extensions of time limits filed after the expiration of the unextended time limit and remedies like continued processing, which have the effect to reinstate the rights of the applicant or owner. It only obliges PLT Contracting Parties to provide for at least one relief for applicants or owners in the case of a missed time limit, subject only to a request and the payment of a fee. ${ }^{166}$ The discussion on Article 11 PLT ("Continued processing and re-instatement of rights without a finding of due care by the Office") was discontinued until agreement on Article 10 PLT was achieved in the Standing Committee. The text of Article 12 PLT ("Re-instatement of rights after a finding of due care or unintentionality by the Office") was "framed" indicating that the Article had been adopted by the Standing Committee.

In the "Report" of the third session of the Standing Committee on the Law of Patents, the basic concept of draft Article 10 PLT providing certain relief without specifying its

162 "Report" (prepared by the International Bureau), Standing Committee on the Law of Patents, Document SCP/2/13 (April 1999), Item 90.

See http://www.wipo.int/meetings/en/details.jsp?meeting_id=3713.

${ }^{163}$ Ibid., Item 92.

${ }^{164}$ Ibid., Item 93.

165 "Draft Patent Law Treaty and Draft Regulations" (prepared by the International Bureau), Standing Committee on the Law of Patents, Document SCP/3/2 (June 1999).

See http://www.wipo.int/meetings/en/details.jsp?meeting_id=3713.

166 "Notes" (prepared by the International Bureau), Standing Committee on the Law of Patents, Document SCP/3/3 (June 1999), Item 10.02.

See http://www.wipo.int/meetings/en/details.jsp?meeting_id=3824. 
mechanism was supported in general. ${ }^{167}$ However, some Delegations preferred to accommodate both requests filed before and after the expiration of the time limit. Based on the discussion, the International Bureau presented a revised text of Article 10 PLT for consideration by the Committee, which reads as follows: ${ }^{168}$

Article 10(1) [Extension of Time Limits]

A Contracting Party may provide for the extension, for the period prescribed in the Regulations, of a time limit fixed by the Office for an action in a procedure before the Office in respect of an application or a patent, if a request to that effect is made to the Office in accordance with the requirements prescribed in the Regulations, and the request is made, at the option of the Contracting Party:

(a) prior to the expiration of the time limit; or

(b) after the expiration of the time limit, and within the time limit prescribed in the Regulations.

Article 10(2) [Continued Processing]

Where an applicant or owner has failed to comply with a time limit fixed by the Office of a Contracting Party for an action in a procedure before the Office in respect of an application or a patent, and that Contracting Party does not provide for extension of a time limit under paragraph (1)(ii), the Contracting Party shall [notify the applicant or owner, and] provide for continued processing with respect to the application or patent and, if necessary, re-instatement of the rights of the applicant or owner with respect to that application or patent, if:

(i) a request to that effect is made to the Office in accordance with the requirements prescribed in the Regulations;

(ii) the request is made, and all of the requirements in respect of which the time limit for the action concerned applied are complied with, within the time limit prescribed in the Regulations.

The above text of Article 10 PLT is a combination of the earlier Articles 10 and 11 PLT and is already relatively close to the text adopted during the Diplomatic Conference. As regards Article 10(1) PLT, several Delegations supported the text suggested by the International Bureau; other Representatives were in favor of replacing "may" by "shall". ${ }^{169}$ With respect to Article 10(2) PLT, a proposal by the Delegation of Germany, supported by other Delegations, to delete the words "[notify the applicant or owner, and]" was adopted. Draft Article 11 PLT was deleted, consequential to the amendment of Article 10 PLT.

\footnotetext{
167 "Report" (adopted by the Standing Committee), Standing Committee on the Law of Patents, Document SCP/3/11 (September 1999), Item 64.

See http://www.wipo.int/meetings/en/details.jsp?meeting_id=3824.

${ }^{168}$ Ibid., Item 71.

${ }^{169}$ Ibid., Item 72.
} 


\subsubsection{Diplomatic Conference for the Adoption of the PLT}

In the Draft Proposal submitted to the Diplomatic Conference for the Adoption of the Patent Law Treaty submitted by the Director General of WIPO, Article 10 PLT on "Relief in respect of time limits" was renumbered to become Article 11 PLT and Article 13 PLT on "Re-instatement of rights after a finding of due care or unintentionality by the Office" was renumbered to become Article 12 PLT. ${ }^{170}$

During the meetings at the Diplomatic Conference for the Adoption of the Patent Law Treaty the filing date requirements were extensively discussed. A Delegation asked whether a PLT Contracting Party was obliged to provide for the extension of time limits even though Article 11(1) PLT was a "may" provision. A representative of the World Intellectual Property Organization (WIPO) referred to Article 11(2) PLT according to which a PLT Contracting Party that did not provide for the extension of time limits after the expiration of the time limit [Article 11(1)(ii) PLT] would be obliged to provide continued processing. ${ }^{171}$ A representative of the European Patent Organization said that Article 11(2) PLT was the core provision of the whole Article, making it mandatory to provide for relief of missed time limits, either in form of an extension of the time limit requested after its expiry, or through continued processing. ${ }^{172}$

A Representative of the Delegation of Singapore said that, according to Article 11(2) PLT, it would appear that if the applicant were not to comply with the requirements after the expiration of the time limit, the PLT Contracting Party should provide for continued processing and, if necessary, reinstate the right of the applicant. This pre-supposed that there was some discretion left to the PLT Contracting Party, whether or not to grant the extension. Concerning the prohibition of other requirements in Article 11(5) PLT, she said that it appeared that a Contracting Party would not be able to ask the applicants for reasons as to why such a delay had occurred. ${ }^{173} \mathrm{~A}$ representative of the WIPO explained that the intent of Article 11 PLT as compared to Article 12 PLT was that a PLT

Contracting Party could not require the furnishing of reasons for which the time limit was missed. The reason for using the work "if necessary" in respect of continued processing was that under different national systems providing for continued processing, some considered that the rights had been lost upon the expiration of the time limit and others consider those rights only to be lost upon the expiration of the period for requesting

170 "Basic Proposal for the Patent Law Treaty" (submitted by the Director General of WIPO), Diplomatic Conference for the Adoption of the Patent Law Treaty, Document PT/DC/3 (November 1999).

See http://www.wipo.int/meetings/en/details.jsp?meeting_id=4057.

${ }_{171}$ Summary Minutes of the Main Committee I (prepared by the International Bureau); $13^{\text {th }}$ session (Monday, May 22, 2000, morning); published in Records of the Diplomatic Conference for the Adoption of the Patent Law (Geneva, 2000) (WIPO Publication 327E), Items 1196 and 1197.

${ }_{172}$ Ibid., Item 1213.

173 Summary Minutes of the Main Committee I (prepared by the International Bureau); $14^{\text {th }}$ session (Monday, May 22, 2000, afternoon); published in Records of the Diplomatic Conference for the Adoption of the Patent Law (Geneva, 2000) (WIPO Publication 327E), Item 1225. 
continued processing. Therefore, in some cases, rights would have to be reinstated and in other cases the rights would not have to be reinstated and there would simply be continued processing. ${ }^{174}$

After discussion, Article 11 PLT and the corresponding Rule 12 PLT were adopted. ${ }^{175}$

With respect to Article 12 PLT, a Representative of the WIPO explained that Article 12 PLT provided for the re-instatement of rights after a finding of due care or unintentionally by the Office. In contrast to Article 11 PLT, Article 12 PLT was not limited to time limits fixed by the Office, but applied to any time limit for an action in a procedure before the Office. It also only dealt with time limits where failure to comply had the direct consequence of causing loss of rights with respect to an application or patent. ${ }^{176}$ There was some discussion on the word "all" in relation to the formulation in item (iv) of Article 12(1) PLT reading "the Office finds it a failure with the time limit occurred in spite of all due care or, at the option of the Contracting Party, that any delay was unintentional." Many Delegations desired to keep the words "due care" whereas the word "all" seemed to create some possibility of misinterpretation and its replacement with another term seemed difficult. Eventually, the word "all" before "due care" was deleted and adopting a special Agreed Statement defining the standard of "due care" was not deemed necessary. ${ }^{177}$

A Representative of the Russian Federation noted that, whereas Article 11(1) PLT placed an express obligation on the Contracting Parties, Article 12 PLT did not. This created the impression it merely confines or requires certain actions of the Office with regard to the reinstatement of rights. He stated that the construction in both should provide for an obligation on the PLT Contracting Party. ${ }^{178}$ The suggestion of a Representative of the WIPO that the problem could be remedied by simply adding the words: "A Contracting Party shall provide that" at the beginning of Article 12(1) PLT was supported and accepted by other Delegations. ${ }^{179}$

After discussion, Article 12 PLT and the corresponding Rule 13 PLT were adopted. ${ }^{180}$

\footnotetext{
174 lbid., Item 1226.

175 Ibid., Items 1199, 1219, 1229, 1257 and 1283.

176 Ibid., Item 1285 .

177 Ibid., Item 1314.

${ }^{178}$ Summary Minutes of the Main Committee I (prepared by the International Bureau); $15^{\text {th }}$ session (Tuesday, May 23, 2000, morning); published in Records of the Diplomatic Conference for the Adoption of the Patent Law (Geneva, 2000) (WIPO Publication 327E), Item 1225.

179 Ibid., Items 1386, 1387 and 1392.

${ }^{180}$ Ibid., Items 1392, 1399, 1400, 1412, 1450 and 1476.
} 


\subsection{Restoration of priority right}

\subsubsection{Committee of Experts on the Patent Law Treaty}

In the "Draft Patent Law Treaty and Draft Regulations" prepared by the International Bureau and presented at the first session of the Committee of Experts on the Patent Law Treaty there was no article on restoration of the priority right. ${ }^{181}$ In the "Report" adopted by the Committee of Experts, a number of Delegations favored, amongst other things, the inclusion in the PLT of provisions relating to restoration of rights. ${ }^{182}$

In the "Draft Patent Law Treaty and Draft Regulations" prepared by the International Bureau and presented at the second session of the Committee of Experts on the Patent Law Treaty there also was no article on restoration of the priority right. ${ }^{183}$ In the "Report" adopted by the Committee of Experts, the Delegation of Canada expressed its support for the proposals for harmonization contained in the documents. Although it recognized the practical constraints involved, the Delegation hoped that it would be possible to deal with a somewhat broader range of issues, for example, the restoration of priority rights where the 12-month priority period was inadvertently missed in spite of all due care required by the circumstances. ${ }^{184}$ In addition, the Representative of the Japan Patent Attorneys Association (JPAA) also proposed that the PLT cover additional topics, such as the restoration of rights. ${ }^{185}$ After a full discussion, the Committee of Experts agreed to recommend that two additional topics should be included in the next draft of the PLT including the belated claiming of priority (delayed submission of priority claim and delayed filing of the subsequent application). ${ }^{186}$

In the "Draft Patent Law Treaty and Draft Regulations" prepared by the International Bureau and presented at the third session of the Committee of Experts on the Patent Law Treaty there was a new Article 13 PLT "Belated claiming of priority" ${ }^{187}$ This provision was

${ }_{181}$ "Draft Patent Law Treaty and Draft Regulations" (prepared by the International Bureau), Committee of Experts on the Patent Law Treaty, Document PLT/CE/I/2 (October 1995).

182 "Report" (adopted by the Committee of Experts), Committee of Experts on the Patent Law Treaty, Document PLT/CE/I/5 (December 1995), Items 46 (Japan), 169 (international Bureau), 200 (observer organization) and 205 (France and AIPPI).

183 "Draft Patent Law Treaty and Draft Regulations" (prepared by the International Bureau), Committee of Experts on the Patent Law Treaty, Document PLT/CE/II/2 (April 1996).

184 "Report" (adopted by the Committee of Experts), Committee of Experts on the Patent Law Treaty, Document PLT/CE/II/5 (June 1996), Item 16.

${ }^{185}$ Ibid., Item 33 .

${ }^{186}$ Ibid., Item 276.

187 "Draft Patent Law Treaty and Draft Regulations" (prepared by the International Bureau), Committee of Experts on the Patent Law Treaty, Document PLT/CE/III/2 (September 1996). 
modeled after Article 7 of the Basic Proposal submitted to the 1991 Diplomatic Conference in relation to the "Patent Harmonization Treaty". ${ }^{188}$

Article 13(1) PLT addresses the situation in which an application which could claim the priority of an earlier application does not, when filed, contain such a claim. The paragraph allows the claiming of priority in a separate declaration filed later than the application. This is permissible since the Paris Convention does not require that the priority claim ("the declaration" containing the priority claim, according to the terminology of Article ${ }_{4} \mathrm{D}(1)$ of that Convention) be contained in the subsequent application itself. ${ }^{189}$ Article 13(2) PLT provides for the restoration of the priority right where a subsequent application is filed after, but within 2 months from, the date on which the priority period expired. It applies only where the failure to file the application within the priority period occurred in spite of all due care required by the circumstances having been taken. ${ }^{190}$

In the meantime, the WIPO General Assembly and the Assembly of the Paris Union (meeting in September/October 1996) considering a Memorandum by the Director General in respect of Matters Concerning the Patent Law Treaty, decided, amongst others, to include provisions relating to the belated claiming of priority (delayed submission of priority claim and delayed filing of the subsequent application) in the draft Patent Law Treaty. ${ }^{191}$

In the subsequent "Report" adopted by the Committee of Experts, the basic concept of draft Article 13 PLT was supported in general. ${ }^{192}$ The Delegation of the United States of America explained that the national procedure of its country provided for the levying of a fee for a request for belated claiming of priority. ${ }^{193}$

In the fourth session of the Committee of Experts on the Patent Law Treaty Article 13 PLT on "Belated claiming of priority" was renumbered to become Article 15 PLT. ${ }^{194}$ In the "Report" adopted by the Committee of Experts, the Delegation of France asked whether,

188 "Records of the Diplomatic Conference for the Conclusion of a Treaty Supplementing the Paris Convention as far as Patents are Concerned - Volume I: First Part of the Diplomatic Conference The Hague, 1991", WIPO Publication No. 351(E), Article 7 "Belated claiming of priority".

189 "Notes" (prepared by the International Bureau), Committee of Experts on the Patent Law Treaty, Document PLT/CE/III/3 (September 1996), Item 12.01.

190 "Draft Patent Law Treaty and Draft Regulations" (prepared by the International Bureau), Committee of Experts on the Patent Law Treaty, Document PLT/CE/III/2 (September 1996), Article 13(2): "Delayed Filing of the Subsequent Application".

191 "Scope of the Patent Law Treaty" (Memorandum by the International Bureau), Committee of Experts on the Patent Law Treaty, Document PLT/CE/III/5 (October 1996).

192 "Report" (adopted by the Committee of Experts), Committee of Experts on the Patent Law Treaty, Document PLT/CE/III/6 (November 1996), Items 17 (Switzerland), 21 (Australia), 32 (Japan Patent Attorneys Association) and 114 (several Delegations).

193 Ibid., Item 202.

194 "Draft Patent Law Treaty and Draft Regulations" (prepared by the International Bureau), Committee of Experts on the Patent Law Treaty, Document PLT/CE/IV/2 (April 1997). 
under Article 15(2)(a) PLT, the priority period would be extended to 14 months or would remain a 12-month period subject to possible restoration and, in the latter case, whether third party rights would be recognized. ${ }^{195}$ The International Bureau replied that the priority period would remain a 12-month period and that third party rights would not be recognized in case of restoration.

In the fifth session of the Committee of Experts on the Patent Law Treaty the title of Article 15 PLT was amended to become: "Addition and restoration of priority claim". ${ }^{196}$ As before, Article 15(1) PLT addresses the situation in which an application which could claim the priority of an earlier application does not, when filed, contain such a priority claim. ${ }^{197}$ Article 15(2) PLT provides for the restoration of the priority right where a subsequent application is filed after, but within 2 months, from the expiration of the priority period. It was noted again that the priority period, namely the 12-month period under Article ${ }_{4} \mathrm{C}(1)$ of the Paris Convention, would not be extended. ${ }^{198}$ Article 15(3) PLT provides a remedy for the applicant where his right of priority is lost because of the failure on the part of the Office with which the earlier application was filed to provide a copy of that application in time for the applicant to comply with the prescribed time limit, despite a timely request for that copy having been made. ${ }^{199}$ A new paragraph (5) was added to Article 15 PLT allowing a PLT Contracting Party to levy a fee in relation to Article 15(1), (2) or (3) PLT to be paid to its Office.

In the "Report" adopted by the Committee of Experts, a number of proposals to amend Article 15 PLT was discussed. ${ }^{200}$ One Delegation suggested that the period of 2 months for making the request under Article 15(2)(a) PLT should be made a minimum. Other Delegations suggested that the period should be the same for each Office. The representative of an intergovernmental organization suggested that the period in question should start from the filing date of the subsequent application. ${ }^{201}$ One Delegation suggested the deletion of the words "and before any technical preparations for publication of the subsequent application have been completed." One Delegation, supported by another Delegation, stated that the requirement that the subsequent

\footnotetext{
195 "Report" (adopted by the Committee of Experts), Committee of Experts on the Patent Law Treaty, Document PLT/CE/IV/4 (June 1997), Item 218.

196 "Draft Patent Law Treaty and Draft Regulations" (prepared by the International Bureau),

Committee of Experts on the Patent Law Treaty, Document PLT/CE/V/2 (October 1997).

See http://www.wipo.int/meetings/en/details.jsp?meeting_id=3286.

197 "Notes" (prepared by the International Bureau), Committee of Experts on the Patent Law

Treaty, Document PLT/CE/V/3 (October 1997), Item 15.03.

See http://www.wipo.int/meetings/en/details.jsp?meeting_id=3286.

${ }^{198}$ Ibid., Item 15.06.

199 lbid., Item 15.12.

200 "Report" (adopted by the Committee of Experts), Committee of Experts on the Patent Law Treaty, Document PLT/CE/V/5 (December 1997), Item 233.

See http://www.wipo.int/meetings/en/details.jsp?meeting_id=3286.

${ }^{201}$ Ibid., Item 233.
} 
application was not received within the priority period "in spite of all due care required by the circumstances" should be replaced by a requirement that the failure to furnish the subsequent application within the priority period was unintentional. ${ }^{202}$ Accordingly, it was agreed that the International Bureau would revise the corresponding provisions.

\subsubsection{Standing Committee on the Law of Patents}

In the "Draft Patent Law Treaty and Draft Regulations" prepared by the International Bureau and presented at the first session of the Standing Committee on the Law of Patents, Article 15 PLT on "Addition and restoration of priority claim" was renumbered to become Article 16 PLT. $^{203}$

Article 16(1) PLT in relation of the addition of a priority claim is modeled after a portion of PCT Rule 26bis.1. ${ }^{204-205}$ Article 16(2) PLT in relation to restoration of the priority was amended to include that the failure to furnish that application within the priority period occurred either in spite of all due care required by the circumstances having been taken, or, at the option of the PLT Contracting Party, was unintentional. ${ }^{206}$

In the "Draft Report" of the first session of the Standing Committee on the Law of Patents, a suggestion was adopted to broaden the scope of Article 16(1) PLT to also include corrections of priority claims, as was the case under PCT Rule 26 bis.1. ${ }^{207}$ Following a proposal by one Delegation, supported by other Delegations, it was agreed that the period from the expiration of the priority date in Article 16(2) PLT should be prescribed in the Regulations as not less than 2 months, and that subparagraph (b) should be deleted. ${ }^{208}$ In response to a question by one Delegation, the International Bureau confirmed that the effect of restoration of the priority right was that protection under the right of priority would extend back to the priority date. ${ }^{209}$

In the "Draft Patent Law Treaty and Draft Regulations" prepared by the International Bureau and presented at the second session of the Standing Committee on the Law of

\footnotetext{
202 Ibid., Item 233.

203 "Draft Patent Law Treaty and Draft Regulations" (prepared by the International Bureau), Standing Committee on the Law of Patents, Document SCP/1/3 (April 1998).

See http://www.wipo.int/meetings/en/details.jsp? meeting_id=3462.

204 "Notes" (prepared by the International Bureau), Standing Committee on the Law of Patents, Document SCP/1/4 (April 1998), Item 16.02.

See http://www.wipo.int/meetings/en/details.jsp?meeting_id=3462.

${ }^{205}$ PCT Rule 26bis.1 entered into force on July 1, 1998.

${ }^{206}$ Ibid., Item 16.06.

207 "Draft Report" (prepared by the International Bureau), Standing Committee on the Law of Patents, Document SCP/1/7 Prov. 1 (June 1998), Item 193.

See http://www.wipo.int/meetings/en/details.jsp?meeting_id=3462.

${ }^{208}$ Ibid., Item 195.

${ }^{209}$ Ibid., Item 196.
} 
Patents, Article 16 PLT was renumbered to become Article 13 PLT. ${ }^{210}$ In the corresponding "Notes" the scope of Articles 13 PLT in relation to Articles 10-12 PLT was explained by the International Bureau (also see $\$$ 5.2.2): Article 13 PLT provides for the addition of a priority claim [Article 13(1) PLT]. In addition, Article 13 PLT provides for the restoration of a priority claim in the case of the delayed filing of the subsequent application [Article 13(2) PLT] or the failure to furnish a copy of the earlier application within the prescribed time limit [Article 13(3) PLT]. In order to avoid the possibility of double relief, the time limits referred to in Article 13(1), (2) and (3)(a) PLT are expressly excluded in the exceptions under Articles 10 to 12 PLT. ${ }^{211}$ Each of Articles 10 to 13 PLT sets the maximum standard which a PLT Contracting Party may apply. A PLT Contracting Party would be permitted, but not obliged, to dispense with any requirement under these Articles, or to apply any requirement or provide any relief which, from the viewpoint of applicants, owners or other interested persons, is more favorable than the requirements or relief prescribed in these Articles and associated Regulations. ${ }^{212}$

In the "Report" adopted by the Standing Committee on the Law of Patents, the Delegation of the Russian Federation proposed to add the words "Correction or" in the title of Article 13 and paragraph (1), for conformance with PCT Rule 26bis.1. ${ }^{213}$ In addition, it was agreed to refer the question of movement of portions of the provision to the Regulations to the International Bureau for further study.

In the "Draft Patent Law Treaty and Draft Regulations" prepared by the International Bureau and presented at the third session of the Standing Committee on the Law of Patents, there were only minor amendment to Article 13 PLT on "Correction, addition or restoration of priority claim". ${ }^{214}$ Later on, the title was amended to read: "Correction or addition of priority claim; restoration of priority right". ${ }^{215}$ In the "Report" of the third session of the Standing Committee on the Law of Patents, only minor amendments were

210 "Draft Patent Law Treaty and Draft Regulations" (prepared by the International Bureau), Standing Committee on the Law of Patents, Document SCP/2/3 (February 1999).

See http://www.wipo.int/meetings/en/details.jsp?meeting_id=3713.

211 "Notes" (prepared by the International Bureau), Standing Committee on the Law of Patents, Document SCP/2/4 (February 1999), Item 10.04.

See http://www.wipo.int/meetings/en/details.jsp?meeting_id=3713.

${ }^{212}$ Ibid., Item 10.05.

213 "Report" (adopted by the Standing Committee), Standing Committee on the Law of Patents, Document SCP/2/13 (April 1999), Item 111.

See http://www.wipo.int/meetings/en/details.jsp?meeting_id=3713.

214 "Draft Patent Law Treaty and Draft Regulations" (prepared by the International Bureau), Standing Committee on the Law of Patents, Document SCP/3/2 (June 1999).

See http://www.wipo.int/meetings/en/details.jsp?meeting_id=3713.

215 "Draft Patent Law Treaty: Working Document" (prepared by the International Bureau), Standing Committee on the Law of Patents, Document SCP/3/7 (July 1999).

See http://www.wipo.int/meetings/en/details.jsp?meeting_id=3713. 
proposed and adopted. ${ }^{216}$ Amongst others, the word "may" in the chapeau of Article 13(1) PLT was changed into "shall". ${ }^{217}$

\subsubsection{Diplomatic Conference for the Adoption of the PLT}

In the Draft Proposal submitted to the Diplomatic Conference for the Adoption of the Patent Law Treaty submitted by the Director General of WIPO, Article 13 PLT on "Correction or Addition of Priority Claim; Restoration of Priority Right" reads as follows (Article 6 relates to formal requirements in respect of the Application): ${ }^{218}$

Article 13(1) [Correction or Addition of Priority Claim]

Except where otherwise prescribed in the Regulations, a Contracting Party shall provide for the correction or addition of a priority claim with respect to an application ("the subsequent application"), if:

(i) a request to that effect is made to the Office in accordance with the requirements prescribed in the Regulations;

(ii) the request is made within the time limit prescribed in the Regulations; and

(iii) the filing date of the subsequent application is not later than the date of the expiration of the priority period calculated from the filing date of the earliest application whose priority is claimed.

Article 13(2) [Delayed Filing of the Subsequent Application]

Where an application ("the subsequent application") which claims or could have claimed the priority of an earlier application has a filing date which is later than the date on which the priority period expired, but within the time limit prescribed in the Regulations, the Office shall restore the right of priority, if:

(i) a request to that effect is made in accordance with the requirements prescribed in the Regulations;

(ii) the request is made within the time limit prescribed in the Regulations;

(iii) the request states the grounds on which it is based; and

(iv) the Office finds that the failure to file the subsequent application within the priority period occurred in spite of all due care required by the circumstances having been taken or, at the option of the Contracting Party, was unintentional.

\footnotetext{
216 "Report" (adopted by the Standing Committee), Standing Committee on the Law of Patents, Document SCP/3/11 (September 1999).

See http://www.wipo.int/meetings/en/details.jsp?meeting_id=3824.

${ }^{217}$ Ibid., Item 8o.

218 "Basic Proposal for the Patent Law Treaty" (submitted by the Director General of WIPO), Diplomatic Conference for the Adoption of the Patent Law Treaty, Document PT/DC/3 (November 1999).

See http://www.wipo.int/meetings/en/details.jsp?meeting_id=4057.
} 
Article 13(3) [Failure to File a Copy of Earlier Application]

Where a copy of an earlier application required under Article 6(5) is not filed with the Office within the time limit prescribed in the Regulations pursuant to Article 6, the Office shall restore the right of priority, if:

(i) a request to that effect is made in accordance with the requirements prescribed in the Regulations; and

(ii) the request is made within the time limit for filing the copy of the earlier application prescribed in the Regulations pursuant to Article 6(5);

(iii) the Office finds that the request for the copy to be provided had been filed with the Office with which the earlier application was filed, within the time limit prescribed in the Regulations.

Article 13(4) [Fees]

A Contracting Party may require that a fee be paid in respect of a request under paragraphs (1) to (3).

Article 13(5) [Opportunity to Make Observations]

A request under paragraphs (1) to (3) may not be refused, totally or in part, without the requesting party being given at least one opportunity to make observations on the intended refusal within a reasonable time limit.

The above text of Article $13 \mathrm{PLT}$ is already relatively close to the text adopted during the Diplomatic Conference.

With respect to Article 13 PLT a representative of the World Intellectual Property Organization explained Article 13 PLT comprised three provisions relating to priority claims, all of which were intended to be very user-friendly. ${ }^{219}$ The remedy of Article 13(1) PLT already existed under the PCT in Rule 26bis.1. With respect to Article 13(2) PLT the Representative of the WIPO explained that this paragraph provided for the restoration of the priority right where the application claiming priority was not received by the Office until after the expiration of the 12-month priority period. It did not provide for an extension of the priority period provided for under the Paris Convention and the provision would apply only after the expiration of that period. ${ }^{220}$

A Representative of the Delegation of Argentina said that his Delegation considered Article 13(2) PLT contrary to the provisions of Article $4 \mathrm{C}(1)$ and (2) of the Paris Convention. Article ${ }_{4} \mathrm{C}$ of the Paris Convention provided that priority periods started from the filing date of the first application. The date from which the 12 months of priority were to be counted was therefore the filing date of the first application. The proposal contained in Article 13(2) PLT meant that, despite the fact that the priority period was

\footnotetext{
${ }^{219}$ Summary Minutes of the Main Committee I (prepared by the International Bureau); $16^{\text {th }}$ session (Tuesday, May 23, 2000, afternoon); published in Records of the Diplomatic Conference for the Adoption of the Patent Law (Geneva, 2000) (WIPO Publication 327E), Item 1483.

${ }^{220}$ Ibid., Item 1502.
} 
12 months, if the applicant showed that, in spite of due care, he had not been able to file the application, the priority period would in effect be changed to 14 months. He considered that that was a violation of the Paris Convention, as it introduced an exception to its provisions. ${ }^{221}$ A Representative of the World Intellectual Property Organization said that the opinion of the Standing Committee, in adopting this provision, had always been that the Paris Convention provided a mandatory priority period of 12 months but did not prevent any country from providing a priority right after that period. Accordingly, it was the understanding of the Standing Committee, in adopting Article 13(2) PLT, was that it was not a breach of the Paris Convention, although it did provide obligations on States that were party to the Paris Convention beyond those provided for in that Convention. ${ }^{222}$ Many Delegations expressed their support for Article 13(2) PLT. A Representative of the European Patent Organization stated that Article 13(2) PLT provided a well-balanced compromise between the general 12-month priority period on the one hand, and the interests of inventors to have a safeguard in exceptional circumstances, on the other. He also stated that the provision did not provide for an extension, but for a restoration of the priority period. ${ }^{223}$ The Representative of the WIPO recalled that the provision under discussion had been included in the draft PLT based on procedures that existed in a number of Member States, because such procedures were felt to be very user-friendly. Noting that each of those Member States might have a different basis for applying this procedure, he stated that it would be very difficult for the Diplomatic Conference to select one of those procedures as a basis and impose it on all States. He emphasized that the relief offered was the most important issue for the purposes of the Treaty. ${ }^{224} \mathrm{~A}$ Representative of the Delegation of Egypt stated that the relationship of Article 13(2) PLT to Article 4 of the Paris Convention remained problematic. He therefore proposed to add the words "taking into consideration the provisions of Article 4 of the Paris Convention" at the beginning of Article 13(2) PLT. ${ }^{225}$ In view of the fact that Article 15 PLT already determined the relationship of the PLT with the Paris Convention by requiring each Contracting Party to comply with the provisions of the Paris Convention, it was, eventually, decided to add to the chapeau of Article 13(2) PLT a reference to Article 15 PLT: "Taking into consideration Article 15, a Contracting Party shall provide that ..." rather than making direct reference to Article 4 of the Paris Convention. ${ }^{226}$

With respect to Article 13(3) PLT, the Representative of the WIPO noted that it was intended to address the situation where the applicant requested a copy of the earlier

\footnotetext{
${ }^{221}$ Ibid., Item 1505.

222 Ibid., Item 1506.

223 Ibid., Item 1529.

224 Ibid., Item 1533.

${ }^{225}$ Ibid., Item 1536.

${ }^{226}$ Summary Minutes of the Main Committee I (prepared by the International Bureau); $26^{\text {th }}$ session (Tuesday, June 1, 2000, morning); published in Records of the Diplomatic Conference for the Adoption of the Patent Law (Geneva, 2000) (WIPO Publication 327E), Item 2602.
} 
application on which the priority claim was based, but as a result of delays in the Office with which the earlier application had been filed, he did not receive it in time to comply with the period for filing that application, which was typically 16 months. ${ }^{27}$ On proposal of the Delegation of Japan, a new paragraph (iv) was added to Article 13(3) PLT in order to provide a basis for the requirement of submitting a copy of the earlier application as prescribed in Rule 14(6)(b)(ii) PLT. ${ }^{228}$ In addition, the words "A Contracting Party shall provide that" were added at the beginning of Article 13(3) PLT as suggested by the International Bureau.

With respect to the issue of the availability of priority documents a proposal by the Delegation of the United Kingdom to include an Agreed Statement to be adopted by the Diplomatic Conference was discussed. ${ }^{229}$ The proposed Statement addressed two issues, namely the speedy supply of copies of priority documents for priority purposes, and the continued availability of applications used to establish priority. ${ }^{230} \mathrm{~A}$ representative of the WIPO said that the network approach to the access to priority documents was consistent with the program which was undertaken at the International Bureau with regard, in particular, to the establishment of the intellectual property digital libraries, that is libraries in electronic forms of various intellectual property related information. One of these libraries would contain priority documents. Such digital libraries could be made available to Offices which could not, or did not wish to, create their own digital libraries. ${ }^{231}$ The Agreed Statement was adopted with some minor drafting amendments. ${ }^{232}$ Agreed Statement 3 adopted by the Diplomatic Conference reads as follows: ${ }^{233}$ "When adopting Articles 6(5) and 13(3), and Rules 4 and 14, the Diplomatic Conference urged the World Intellectual Property Organization to expedite the creation of a digital library system for priority documents. Such a system would be of benefit to patent owners and others wanting access to priority documents."

\subsection{Discussion}

Since the continuation of the 1991 Diplomatic Conference in The Hague on the harmonization of the substantive provisions of patent laws had become impossible in

227 Summary Minutes of the Main Committee I (prepared by the International Bureau); $16^{\text {th }}$ session (Tuesday, May 23, 2000, afternoon); published in Records of the Diplomatic Conference for the Adoption of the Patent Law (Geneva, 2000) (WIPO Publication 327E), Item 1573.

${ }^{228}$ Ibid., Item 1586.

${ }^{229}$ Summary Minutes of the Main Committee I (prepared by the International Bureau); $22^{\text {nd }}$ session (Friday, May 26, 2000, evening); published in Records of the Diplomatic Conference for the Adoption of the Patent Law (Geneva, 2000) (WIPO Publication 327E), Item 2236.

${ }^{230}$ Ibid., Item 2237.

${ }^{231}$ Ibid., Item 2238.

${ }^{232}$ Ibid., Item 2268.

233 "Agreed Statements by the Diplomatic Conference regarding the Patent Law Treaty and the Regulations under the Patent Law Treaty adopted by the Diplomatic Conference on June 1, 2000", Statement 3.

See http://www.wipo.int/treaties/en/ip/plt/statements.html. 
view of the position taken by the Delegation of the United States of America (see $₫ 1$ and \5), the World Intellectual Property Organization (WIPO) incited new negotiations in 1995 which eventually resulted in the adoption of the Patent Law Treaty (PLT) during a Diplomatic Conference held in 2000. The resulting PLT focuses on the harmonization of patent formalities with the aim of stimulating uniformity, simplification and cost reduction within the international patent system.

During the negotiation process, a number of provisions in the PLT were modeled after texts of Articles already contained in the Basic Proposal submitted to the 1991 Diplomatic Conference in relation to the "Patent Harmonization Treaty". ${ }^{234}$ In addition, many proposals to amend the Draft Articles and Draft Regulations under the PLT were brought forward by the Delegations in order to accommodate the local practice in their home countries. If no agreement could be reached on the implementation of such a requirement often the desired amendment was incorporated in the PLT but without prescribing that this was mandatory. As a consequence, the Patent Law Treaty contains a mix of compulsory requirements ("shall") and optional requirements which may be implemented as compulsory ("may require") by a PLT Contracting Party. Such diversity of requirements does not stimulate the achievement of the goal of the PLT to "streamline and harmonize" formal requirements set by national and regional Patent Offices for the filing of national or regional patent applications, the maintenance of patents and certain additional requirements. ${ }^{235}$

From studying the documents relating to the negotiation history of the Patent Law Treaty, it can be inferred that the role of the World Intellectual Property Organization (WIPO) in the negotiation process resulting in the PLT was more of a facilitating nature than aimed at obtaining a Treaty that encompasses mainly compulsory requirements. The inclusion of optional requirements should only have been allowed in a limited number of exceptional cases. On the other hand, it can be understood that the desire to reach an agreement on a Patent Law Treaty, often made it necessary to bridge differences; this was not always possible, and this is one of the reasons why there are so many alternative routes in the PLT.

\footnotetext{
234 "Records of the Diplomatic Conference for the Conclusion of a Treaty Supplementing the Paris Convention as far as Patents are Concerned - Volume I: First Part of the Diplomatic Conference The Hague, 1991", WIPO Publication No. 351(E).

235 "Basic Features to the Patent Law Treaty" (prepared by the International Bureau) (November 2006), Item 2.

See http://www.wipo.int/patent-law/en/plt.htm.
} 


\section{Guidance by WIPO}

The World Intellectual Property Organization (WIPO) is a specialized agency of the United Nations. ${ }^{236}$ It is dedicated to developing a balanced and accessible international intellectual property system. ${ }^{237}$

During the negotiation process of the Patent Law Treaty, the WIPO played an active role by preparing draft texts of the PLT and its Regulations, looking for compromises and seeking political agreement between the interests of the various States.

Since the adoption of the Patent Law Treaty $(P L T)$, the involvement of the World Intellectual Property Organization (WIPO) has diminished because there are no centralized functions. The International Bureau of WIPO merely acts as depository of the PLT and is not in a position to give an official interpretation of the Treaty, as such interpretation is the exclusive competence of the PLT Contracting Parties.

The International Bureau has issued a set of Explanatory Notes on the PLT and Regulations under the PLT; the Notes have not been adopted by the Diplomatic Conference. ${ }^{238}$ These Notes are helpful in understanding the meaning of the PLT. However, these texts are based on the Notes prepared by the International Bureau of the World Intellectual Property Organization in preparation for the meetings of the Committee of Experts on the Patent Law Treaty and the Standing Committee on the Law of Patents (SCP), which are sometimes difficult to understand, if one has not followed the developments during the negotiation process.

In order to stimulate the electronic distribution of draft modifications in the Treaty and the submission of comments and observations, a PLT Web Forum was established following a decision of the PLT Assembly at its first session, which was held in Geneva during the forty-first series of meetings of the Assemblies of the Member States of WIPO (September 26 to October 5, 2005). ${ }^{239}$ The PLT Web Forum is intended to be used for consultations prior to the meetings of the PLT Assembly.

As the PLT is a mix of compulsory requirements ("shall") and optional requirements which may be implemented as compulsory ("may require") by a PLT Contracting Party,

\footnotetext{
236 "Agreement between the United Nations and the World Intellectual Property Organization" (Agreement entered into effect on December 17, 1974).

See http://www.wipo.int/treaties/en/agreement/.

237 "Convention Establishing the World Intellectual Property Organization" (signed at Stockholm on July 14, 1967 and as amended on September 28, 1979 (document WOo29EN).

See http://www.wipo.int/treaties/en/convention/trtdocs_woo2g.html.

238 "Explanatory Notes on the Patent Law Treaty and Regulations under the Patent Law Treaty adopted by the Diplomatic Conference on June 1, 2000" (prepared by the International Bureau), Diplomatic Conference for the adoption of the PLT, Document PT/DC/48 Prov. (November 2000), Note 5.23.

See http://www.wipo.int/meetings/en/details.jsp?meeting_id=4057.

${ }^{239}$ See http://www.wipo.int/meetings/en/details.jsp?meeting_id=9003.
} 
there are a lot of choices to be made when implementing the PLT into the national/regional patent law of an aspirant PLT Contracting Party. ${ }^{240}$

In 2010 a Questionnaire was established and placed on the PLT Web Forum to collect information from the PLT Contracting Parties on how the PLT is implemented at the national/regional level, and to share such information with current and future PLT Contracting Parties, as well as with patent practitioners and the public. ${ }^{241}$ The Questionnaire encompasses 11 categories of questions, amongst which are the following ones:

- Question 1 - Filing date [Article 5 and Rule 2 PLT];

- Question 4-Relief in respect of time limits [Article 11 and Rule 12 PLT];

- Question 5-Reinstatement of Rights [Article 12 and Rule 13 PLT];

- Question 6 - Restoration of priority rights where the filing of the subsequent application was delayed [Article 13(2) and Rule 14(4) and (5) PLT];

$\circ$ Question 7-Restoration of priority rights where the filing of a copy of the earlier application was delayed [Article 13(3) and Rule 14(6) PLT].

Most of these Questions are split into a number of sub-questions. By way of example, two of the six sub-questions of Question 1 read as follows:

Q1-2 Does your Office accept a drawing as the element referred to as "a part which on the face of it appears to be a description" in Article 5(1)(a)(iii) PLT? [Reference: Article 5(1)(b) PLT].

Q1-5 For the filing date to be determined under Article 5(6)(b) PLT (filing of a missing part of the description or a missing drawing), which of the optional elements referred to in Rule 2(4) PLT are required by your Office?

[Reference: Rule 2(4) PLT].

Q1-6 For a reference to a previously filed application to replace the description and any drawing for the purpose of the filing date under Article 5(7) PLT, which of the requirements referred to in Rule 2(5) PLT are required by your Office?

[Reference: Rule 2(5) PLT]

A number of PLT Contracting Parties have posted answers to the Questionnaire. ${ }^{242}$ From the responses a large variety of choices can be observed. With respect to Q1-2 (Is a "drawing" accepted as a "description"?), 8 PLT Contracting Parties answered "Yes", 11 "No" and one Party answered: "This is something we would consider on a case by case basis if and when it arose." ${ }^{243}$

\footnotetext{
${ }^{240}$ In the Articles of the PLT there are 19 occurrences and in the PLT Rules 58 occurrences of the wording "may require".

${ }^{241}$ See http://www.wipo.int/plt-forum/en/questionnaire/.

${ }^{242}$ See http://www.wipo.int/plt-forum/en/questionnaire/table.html. Currently (November 2011), 20 of the 28 PLT Contracting Pasties have responded to the Questionnaire.

${ }^{243}$ Great Britain.
} 
With respect to Q1-5 ("filing missing parts of the description or missing drawings") six sub-questions have to be answered in relation to "which of the optional elements referred to in PLT Rule 2(4) are required by your Office?" 244

\begin{tabular}{|l|c|c|}
\hline Question Q1-5 & Yes & No \\
\hline $\begin{array}{l}\text { (a) A copy of the earlier application } \\
\text { correct }\end{array}$ & 16 & 3 \\
\hline (b) A translation of the earlier application & 12 & 7 \\
\hline $\begin{array}{l}\text { (d) The missing part of the description or missing drawing must be } \\
\text { completely contained in the earlier application }\end{array}$ & 16 & 3 \\
\hline $\begin{array}{l}\text { (e) The application must contain an indication that the contents of } \\
\text { the earlier application were incorporated by reference }\end{array}$ & 9 & 10 \\
\hline $\begin{array}{l}\text { (f) An indication as to where the missing part of the description or the } \\
\text { missing drawing is contained in the earlier application or in the } \\
\text { translation }\end{array}$ & 8 & 11 \\
\hline
\end{tabular}

With respect to Q1-6 ("filing by reference") five sub-questions have to be answered in relation to "which of the requirements referred to in PLT Rule 2(5) are required by your Office?" ${ }^{245}$

\begin{tabular}{|l|c|c|}
\hline Question Q1-6 & Yes & No \\
\hline $\begin{array}{l}\text { (a) The reference to a previously filed application must indicate the } \\
\text { filing date of the previously filed application }\end{array}$ & 14 & 5 \\
\hline (b) A copy of the previously filed application & 15 & 4 \\
\hline (c) A copy of the previously filed application, certified as correct & 5 & 14 \\
\hline (d) A translation of the previously filed application & 13 & 6 \\
\hline $\begin{array}{l}\text { (e) The reference mentioned in PLT Article 5(7)(a) shall be to a } \\
\text { previously filed application that has been filed by the applicant or } \\
\text { his predecessor or successor in title }\end{array}$ & 9 & 10 \\
\hline
\end{tabular}

From the above comparison, it can be concluded that when a country considers becoming a Contracting Party to the PLT, studying the responses to the Questionnaire is not very helpful in making choices.

\footnotetext{
${ }^{244}$ Ukraine declared that this procedure is "not applicable" in its Office.

${ }^{245}$ Serbia has declared that the Serbian Patent Law does not contain such provisions.
} 
When asked, the World Intellectual Property Organization (WIPO) provides assistance to an aspirant PLT Contracting Party. Example texts have been prepared by the WIPO which can be used as a guidance on how the requirements of the PLT can be implemented in the national/regional law; these texts have no official status.

Two examples are given here. The first example of a textual suggestion relates to the requirements for the accordance of a filing date [Article ${ }_{5}$ PLT]. Such an Article could be formulated as follows: ${ }^{246}$

"Filing date of the Application

1. The accordance of the filing date of an application shall require that on such a date the application filed with the Institution contains:

(a) an express indication that the grant of a patent is applied for;

(b) information identifying the applicant or allowing the applicant to be contacted; and

(c) a part which on the face of it appears to be a description, or reference to a previously filed application.

2. A reference to a previously filed application under paragraph 1 (c) shall state the filing date and number of that application and the Office with which that application was filed. The reference shall indicate that it replaces the description for the purpose of the filing date.

3. Where the application contains a reference under paragraph 2, a copy of the previously filed application shall be filed within two months from the date on which the application containing the reference was received by the Institute. Where the previously filed application is not in one of the official languages of [ ], a translation thereof shall be filed within the same period."

The second example relates to the remedy of "continued processing". With respect to providing relieve in respect of time limits, a PLT Contracting Party may provide for the extension of a time limit fixed by the Office for an action in a procedure before the Office, if a request to that effect is made to the Office in accordance with the requirements prescribed in the Regulations, and the request is filed, at the option of the Contracting Party either prior to the expiration of the time limit, or after the expiration of the time limit [Article 11(1) and Rule 12(1) PLT]. In principle, the Patent Law Treaty does not oblige a PLT Contracting Party to impose continued processing. However, the relief is mandatory if it is not allowed to file the request for an extension of a time limit after the expiration of the time limit [Article 11(2) and Rule 12(3) and (4) PLT]. This implies that if a PLT Contracting Party chooses that the request for the extension of the time limit can only be filed before the expiration thereof, providing continued processing is mandatory,

${ }^{246}$ Note that this text is more or less the same as what can be found in Rule 4O(1) implementing the filing date requirements of Article 80 of the European Patent Convention (EPC 2000). 
but if a giving country allows that the request for extension can be filed after the expired time limit (but within a certain period of time - Rule 12(2)(b) PLT), there is no need providing for continued processing provisions. On the other hand, if the national law of a PLT Contracting Party (already) has a provision on continued processing, it is not mandatory to provide for the extension of time limits [see the wording "may provide for the extension" in the chapeau of Article 11(1) PLT].

A textual suggestion in relation to providing "continued processing" in the patent law of a PLT Contracting Party reads as follows:

1) If the applicant for a patent has failed to perform an act in the course of the procedure before the Institute within a time limit prescribed by this Law [or the Regulations], the direct result of which is a loss of rights conferred by a patent application, he may file a request for the continued processing. The Institute shall allow the continued processing, provided that the applicant:

(a) files a request for the continued processing, and performs all the omitted acts within a time limit referred to in paragraph 2 of this Article;

(b) pays the fee and procedural charges in accordance with Article [ ] of this Law.

2) A time limit for filing a request and for the performance of the omitted acts referred to in paragraph 1 of this Article shall be two months from the notification to the applicant or holder of a patent.

3) If the omitted acts have not been performed within a time limit referred to in paragraph 2 of this Article, or if the fees and procedural charges referred to in Article [ ] of this Law have not been paid, a request for the continued processing shall be considered as not filed, and the Institute shall issue a conclusion to that effect.

4) A request for the continued processing shall not be filed in the case of failure to comply with a time limit:

(a) referred to in paragraph 2 of this Article,

(b) $[\ldots]$

(c) for performing all the acts in the appeal procedure,

(d) for actions in inter partes proceedings.

5) The content of the request, the conditions and the procedure concerning the request referred to in paragraph 1 of this Article shall be regulated more specifically by the Implementing Regulations.

An aspirant PLT Contracting Party is, of course, entirely free to make its own choices when implementing the Patent Law Treaty in its national/regional patent law.

Nevertheless, it is believed that such textual suggestions would be very helpful in understanding and illustrating the scope of the PLT and would stimulate a more uniform 
implementation of the PLT in national/regional patent laws. A more active role of the World Intellectual Property Organization would be welcomed in this respect.

\section{Research questions}

In this thesis the degree of alignment of the European Patent Convention (EPC) and the Patent Cooperation Treaty (PCT) with requirements of the Patent Law Treaty (PLT) is investigated.

- In Chapter II the requirements in the EPC for the accordance of a date of filing and the option to file missing parts of the description or missing drawings are investigated and compared to the requirements of the PLT.

- In Chapter III the requirements in the EPC are studied for filing a European patent application by reference to a previously filed application in relation to the requirements of the PLT.

- In Chapter IV the requirements in the PCT for the accordance of a date of filing and the option to file missing parts of the description or missing drawings are investigated and compared to requirements of the PLT.

- In Chapter V the requirements in the EPC for the extension of time limits and the remedy of further processing are investigated and compared to the requirements of the PLT.

- In Chapter VI the requirements in respect of the remedy of re-establishment of rights under the EPC are investigated and compared with the requirements in respect of the remedies of reinstatement of rights and restoration of priority right under the PLT.

- In Chapter VII the requirements in the PCT for relief in respect of time limits under the PLT and the remedy of reinstatement of rights in the PCT are investigated and compared to the requirements of the PLT. 
This page was left blank intentionally. 


\section{Chapter II - Filing date requirements under the EPC - an option to extend subject-matter? ${ }^{1}$}

\section{Introduction}

The Patent Law Treaty (PLT) entered into force in April 2005. The aim of the PLT is "to harmonize and streamline", on a world-wide basis, formal procedures relating to national and regional patent applications and maintenance of patents. As the formality requirements for filing a patent application vary from country to country, the PLT aims at simplifying and harmonizing the rules in all participating countries. The PLT does not establish a uniform procedure for all PLT Contracting Parties but leaves Parties free to require fewer or more user-friendly requirements than those provided in the PLT.

During the past few years the main features of the Patent Law Treaty have been implemented in the Patent Cooperation Treaty and in the European Patent Convention. Whereas the EPO has implemented all options of the PLT during the EPC 2000 revision, the PCT could only implement a subset of the PLT because the articles of the PCT could not be amended.

\section{Filing date requirements - Article 5 PLT}

Article 5 of the PLT governs the requirements for the accordance of a date of filing. ${ }^{2}$ In particular, Article 5(1) PLT prescribes the elements of an application to be filed for the purpose of according a date of filing. Firstly, the Office receiving the application documents needs to be satisfied that the elements that it has received are intended as an application for a patent. Secondly, the Office must be provided with indications which identify the applicant and/or allow the applicant to be contacted. Instead of such indications, the Office may accept evidence allowing the identity of the applicant to be established or allowing the applicant to be contacted by the Office. Thirdly, the Office must have received a disclosure of the invention, either in the form of what appears to be a description or, where permitted, a drawing in place of that description. In addition, Article 5(7) PLT obliges a Contracting Party to accept, at the time of filing, the

1 This Chapter is an updated version of an earlier publication: Cees Mulder and Derk Visser: "Filing date requirements under the EPC - an option to extend subject-matter?" in epi Information 2|10, pp. 44-48.

See http://216.92.57.242/patentepi/en/Information/epi-information.php.

This article has been drafted by the present author Cees Mulder, and completed by him, taking into account valuable comments and suggestions by Derk Visser, who is therefore mentioned as co-author.

2 The Patent Law Treaty was adopted on 1 June 2000 at a Diplomatic Conference in Geneva; the Treaty entered into force on 28 April 2005. See WIPO Publication No. 258(E).

See http://www.wipo.int/treaties/en/ip/plt/. 
replacement of the description and any drawings in an application by a reference to a previously filed application, subject to certain formal requirements. ${ }^{3}$

A Contracting Party is obliged to accord a date of filing to an application which complies with the requirements of Article 5 PLT. Since the list of elements under Article 5(1) PLT is exhaustive, a PLT Contracting Party is not permitted to require any additional elements for a filing date to be accorded 4 . In particular, it is not permitted to require that the application contains one or more claims, compliance with formal requirements (e.g. that handwritten applications are not accepted), use of a prescribed language, or payment of a filing fee. ${ }^{5}$

\section{Implementation of the PLT in the EPC}

Upon revising the European Patent Convention resulting in the so-called EPC 2000, ${ }^{6}$ the requirements set by the PLT were implemented into the EPC. Amongst others, the following items were adopted in the Implementing Regulations of the EPC:

- Requirements for according a date of filing to a patent application [Article 5(1) PLT; Rule $40 \mathrm{EPC}$ ] including relief with respect to language requirements [Article 5(2)(b) PLT; Article 14(2) EPC implying that an application may be filed in any language];

- Filing a description and/or drawings by a reference to another application [Article 5(7) PLT; Rule 40(1)(c) EPC];

- Filing missing parts of the description or missing drawings [Article 5(6) PLT; Rule 56 $\mathrm{EPC}] ;$

- Addition or correction of a priority claim [Article 13(1) PLT; Rule 52(2) and (3) EPC];

o Restoration of right to priority [Article 13(2) PLT; Rule 136(1) EPC].

The EPO has chosen for a complete implementation of the PLT in the EPC. In contrast, the PCT has only included a limited set of options of the PLT, because the Articles of the PCT could not be changed. In this publication a few peculiarities will be discussed relating to the specific implementation of the PLT into the EPC.

\subsection{Filing date requirements - Rule 40 EPC}

The requirements set out in Article 5 PLT have been incorporated in Rule 40 EPC, implementing Article 80 EPC (all references to the EPC are to the EPC 2000). Rule 40(1) EPC prescribes that the date of filing of a European patent application is the date on which the documents filed by the applicant contain:

3 "Explanatory Notes on the PLT and the Regulations under the PLT", WIPO Publication No. 258(E), Note 5.23 .

4 Ibid., Note 5.02.

5 Ibid., Note 5.02.

6 The revised European Patent Convention (EPC 2000) was adopted on 29 November 2000 at a Diplomatic Conference in Munich and entered into force on 13 December 2007i see http://www.epo.org/patents/law/legal-texts/epc.html. 
(a) an indication that a European patent is sought;

(b) information identifying the applicant or allowing the applicant to be contacted; and

(c) a description or reference to a previously filed application.

Rule 40(2) and (3) EPC deal with further requirements in the case where the applicant, instead of filing a description, refers to a previously filed application. In particular, Rule 40(2) EPC states that in this case the applicant must state the filing date and number of that application and the Office ${ }^{7}$ with which it was filed, and indicate that the reference replaces the description and any drawings. In addition, Rule 40(3) EPC requires an applicant to file a certified copy of the previously filed application within two months of filing the application. Since Rule 53(2) EPC applies mutatis mutandis, the applicant need not file a copy of the previously filed application where this application is already available to the EPO under the conditions specified by the President. ${ }^{8}$ Where the previously filed application is not in an official language of the EPO, a translation thereof in one of these languages shall be filed within the same period.

When filing by reference, the date of filing accorded will be the date on which the applicant complies with requirements (a) and (b) and correctly identifies the earlier application [Rule 40(2) EPC]. If the applicant later on furnishes the certified copy of the previously filed application in due time or the previously filed application is in the files of the EPO, all requirements for obtaining a filing date are met.

If the applicant does not provide the certified copy of the previously filed application in due time [Rule 40(3) EPC, first sentence] and such copy is not already available to the EPO, the applicant will receive a communication under Rule 55 EPC, requesting him to file the certified copy within a non-extendable period of two months. If he files the certified copy within this period, the application will retain the filing date originally-accorded by the EPO. If the applicant does not provide the certified copy in due time, the application will not be treated by the EPO as a European patent application. ${ }^{9}$ This implies that the filing date which was already accorded upon filing the reference to the previously filed application is taken away retroactively.

The requirement in Rule 40(3) EPC that the applicant must file a translation of the previously filed application, where that application is not in an official language of the EPO, has no influence on the accordance of the date of filing, in spite of the fact that the requirement is provided in Rule 40 EPC. Hence, if the applicant does not furnish a

7 Note that, contrary to the wording of Rule 40(2) EPC, the Request-for-Grant form (EPO Form 1001) requires the applicant to fill in the "State" where the previous application was filed.

See http://www.epo.org/applying/forms-fees/forms.html.

8 Guidelines for Examination in the European Patent Office (April 2010); Part A, Chapter II, \$4.1.3.1. see http://www.epo.org/patents/law/legal-texts/guidelines.html.

9 Ibid., Part A, Chapter II, $\$$ 4.1.5. 
required translation of the previously filed application, the date of filing already accorded to his application is not taken away (retroactively). In the last sentence of Guidelines Part A, Chapter II, $\$ 4.1 .4$, the EPO confirms that: "The filing date is unaffected by a missing translation." In the case of a missing translation pursuant Rule 40(3) EPC, the EPO will send the applicant not a communication according to Rule 55 EPC but a communication according to Rule $58 \mathrm{EPC}$, informing him that the required translation has not been filed and requesting him to file the translation within a non-extendable period of two months. ${ }^{10}$

As Rule 55 EPC implements Article 90(1) EPC [accordance of a date of filing] and Rule 57 and Rule 58 EPC implement Article 9o(3) and Article 9o(4) EPC, respectively [examination of formality requirements], the furnishing of a required translation of the previously filed application should not have been included in Rule 40 EPC. The presence of the translation requirement in Rule 40 EPC is confusing, because its title, "Date of filing", suggests that all requirements listed in Rule 40 EPC have to be met in order to meet the requirements for the accordance of a date of filing.

In the opinion of the author, the requirement in Rule 40(3) EPC that the applicant must file a translation of the previously filed application, where that application is not in an official language of the EPO, should be removed from Rule 40 EPC because it does not belong to the requirements for the accordance of a date of filing, and does not implement Article 8o EPC.

It is proposed to include the translation requirement in Rule 6(1) EPC by adding a reference in the provision to Rule 40(3) EPC, which makes it clear that the provision of the translation is not a filing date requirement. The addition to Rule 6(1) EPC has the further advantage that it is immediately clear that the translation of a previous application filed under Rule 40(3) EPC is a translation under Article 14(2) EPC because of the reference in Rule 6(1) EPC to this Article. Without the connection with Article 14(2) $E P C$, it is not clear whether the translation may be corrected after filing by bringing it into conformity with the application as filed and what the sanction is on not filing the translation (deemed withdrawn). At present, the possibility for correction and the sanction have only a basis in the Guidelines. ${ }^{11}$ It should be noted that even the Explanatory Notes of the EPO to the Implementing Regulations ${ }^{12}$ regarded the

10 Ibid., Part A, Chapter II, $\ 4.1 .5$ and Chapter III, $\ 14$.

11 Ibid., Part A, Chapter III, $\ 14$ : "Failure to file the translation on time in response to the invitation under Rule 58 EPC results in the application being deemed to be withdrawn according to Article 14(2) EPC. The EPO will then notify the applicant of this loss of rights according to Rule 112(1) EPC.

12 "Revision of the European Patent Convention (EPC 2000). Synoptic presentation EPC 1973/2000 - Part II: The EPC Implementing Regulations", EPO Official Journal 2007, Special Edition No. 5i comment in relation to Rule 57 EPC.

See http://www.epo.org/patents/law/legal-texts/journal/2007.html. 
translation requirement in Rule 40(3) EPC to be a lex specialis, not related to Article 14(2) EPC, having refusal under Article 9o(5) EPC as sanction.

\subsection{Filing missing items - Article 5(6) PLT}

Article 5(6) PLT obliges a PLT Contracting Party to allow the inclusion, in the application, of a missing part of the description or a missing drawing that is filed within a prescribed time limit. ${ }^{13}$ It applies whether or not the applicant has been notified of a missing item. Normally, the late filing of a missing item causes the filing date to become the date of receipt of the missing item, provided that all of the other requirements for the according of a filing date are complied with on that date [cf. Rule 2(3) PLT].

In particular, Article 5(6)(b) PLT obliges a Contracting Party to allow, upon the request of the applicant, the inclusion of a missing part of the description or of a missing drawing in the application without loss of the filing date, where that missing part or missing drawing is "completely contained" in an earlier application from which priority is claimed, provided the additional formality requirements are complied with [cf. Rule 2(3) and (4) $\mathrm{PLT}] .{ }^{14}$ The PLT leaves the question of whether, in a particular case, a missing part of the description or a missing drawing is completely contained in the earlier application to the Office to determine on the facts of that case.

The wording of Article 5(6)(b) PLT is very specific with respect to the nature of the earlier application and by when that application must be mentioned:

Where the missing part of the description or the missing drawing is filed under subparagraph (a) to rectify its omission from an application which, at the date on which one or more elements referred to in paragraph (1)(a) were first received by the Office, claims the priority of an earlier application, the filing date shall, upon the request of the applicant filed within a time limit prescribed in the Regulations, and subject to the requirements prescribed in the Regulations, be the date on which all the requirements applied by the Contracting Party under paragraphs (1) and (2) are complied with.

The italicised part of the above paragraph makes clear that when the applicant desires to make use of the provision of Article 5(6)(b) PLT to incorporate a missing part of the description or a missing drawing into an already filed application without loss of the filing date initially accorded by the Office, the earlier application must not only be a priority application but also that the priority of this earlier application must have been claimed on "the date on which one or more elements" referred to in Article 1(a) PLT "were first received by the Office".

13 "Explanatory Notes on the PLT and the Regulations under the PLT" (WIPO Publication No.258), Note 5.20.

${ }^{14}$ Ibid., Note 5.21. 
Note, that the $\mathrm{PCT}^{15}$ upon implementing the filing of missing items without loss of the initial filing date [see e.g. PCT Rule 20.6] has taken over, in PCT Rule 4.18, the literal wording of Article 5(6)(b) PLT, stating:

Where the international application, on the date on which one or more elements referred to in PCT Article 11(1)(iii) were first received by the receiving Office, claims the priority of an earlier application, the request may contain a statement that, where an element of the international application referred to in PCT Article 11(1)(iii)(d) or (e) or a part of the description, claims or drawings referred to in PCT Rule 20.5(a) is not otherwise contained in the international application but is completely contained in the earlier application, ...

The PCT does not allow late filing of missing items based on a priority claim added after the date of filing. ${ }^{16}$

\subsection{Filing missing items - Rule 56 EPC}

The requirements as set out in the Article 5(6) PLT for filing missing items have been taken over in Rule 56 EPC implementing Article 90 EPC.

After receipt of the application, the EPO will first examine whether the application is entitled to a date of filing. If during this check the EPO notes that parts of the description or that drawings appear to be missing, it will invite the applicant to file the missing items within two months from invitation [Rule 56(1) EPC]. If the applicant does not reply to this invitation in time, all references to the missing items are deemed to be deleted [Rule $56(4)(a) E P C] .{ }^{17}$

According to Rule 56(2) EPC, the applicant may also file missing parts of the description or file missing drawings of his own motion (without being invited to do so by the EPO) within two months of the date of filing. In the (rare) event, that the applicant is invited by the EPO to file the missing item, the 2-month period under Rule 56(1) EPC takes precedence over the 2-month period of Rule 56(2) EPC, the latter period always expiring earlier because it is coupled to the initially accorded filing date. The last sentence of Rule 56(1) EPC stipulates that the applicant may not invoke the omission of a communication from the EPO under Rule 56(1) EPC.

If an applicant files a missing part of the description or a missing drawing of his own motion or upon invitation from the EPO, the normal situation is that the application is re-dated to the date on which the missing item is received by the EPO; the EPO informs

15 On 1 April 2007, the Regulations under the Patent Cooperation Treaty were amended to implement provisions of the Patent Law Treaty; for the text of the PCT Regulations as in force since 1 July 2009, see http://www.wipo.int/export/sites/www/pct/en/texts/pdf/pct_regs.pdf.

16 PCT Applicant's Guide - International Phase, item 6.028, see http://www.wipo.int/pct/guide/en/gdvol1/pdf/gdvol1.pdf.

17 Guidelines for Examination in the EPO (April 2010), Part A, Chapter II, \$5.1. 
the applicant accordingly [Rule 56(2) EPC]. ${ }^{18}$ If the applicant is "not happy" with the later filing date, because, e.g., he realises that the re-dating causes him to lose priority from an earlier application, he can retract the effect of the re-dating by withdrawing the missing item(s) within one month from the communication of Rule 56(2) EPC, in which case the re-dating is deemed not to have been made [Rule 56(6) EPC]. ${ }^{19}$

In paragraph 3 of Rule 56 EPC, the EPO allows an applicant to file missing parts of the description or to file missing drawings (within the prescribed periods) without loss of the initial filing date. Of course, a lot of requirements have to be met in order to allow for this; the Guidelines Part A, Chapter II, $\$ 5.4$ summarize the criteria to be satisfied:

(i) the missing parts are filed within the applicable time limit;

(ii) the application claims priority;

(iii) the applicant requests that the late-filed parts be based on the claimed priority in order to avoid a change in the date of filing, and does so within the applicable time limit;

(iv) the late-filed parts of the description, or drawings, are completely contained in the claimed priority application;

(v) the applicant files a copy of the priority application within the applicable time limit, unless such copy is already available to the EPO under Rule 53(2) EPC [Rule 56(3)(a) $E P C] ;$

(vi) where the priority document is not in an official language of the EPO, the applicant files a translation into one of these languages within the applicable time limit, unless such a translation is already available to the EPO under Rule 53(3) EPC [Rule 56(3)(b) EPC];

(vii) the applicant indicates where in the priority document and, if applicable, where in its translation, the late-filed missing parts of the description, or drawings, are completely contained, and does so within the applicable time limit [Rule 56(3)(c) EPC].

The "applicable" time limit mentioned above is either the 2-month period of Rule 56(1) [invitation from the EPO to file missing items] or the 2-month period of Rule 56(2) EPC [applicant files missing items of his own motion].

If a request according to Rule 56(3) EPC does not comply with one or more of the above requirements (ii)-(iv), the date of filing will change to the date on which the EPO received the late-filed missing items of the application; the EPO informs the applicant accordingly [Rule 56(2) EPC]. If the request according to Rule 56(3) EPC does not comply with one or more of the above requirements (v)-(vii), the date of filing will change to the date on

18 Ibid., Part A, Chapter II, $\$ 5 \cdot 3$.

19 Ibid., Part A, Chapter III, $\$ 3.2 .2$. 
which the EPO received the late-filed missing items of the application; the EPO informs the applicant accordingly [Rule 56(5) EPC]. ${ }^{20}$

The formulation of Rule 56(3) EPC requires that "... the application claims priority of an earlier application ..." but it does not prescribe when such a priority claim must be made. The Guidelines specify in this respect: ${ }^{21}$

Where the applicant files a request under Rule 56(3) EPC, the priority claim in question must have been in existence no later than the filing of this request. To this end, the applicant can file a simultaneous request, contained in one single submission:

(i) to insert a new priority claim not present when the application was filed according to Rule 52(2) EPC, and

(ii) to base late-filed missing parts of the description, or drawings, on that priority claim according to Rule 56(3) EPC.

This is subject to the proviso that the above simultaneous request respects both the time limit according to Rule 52(2) EPC for insertion of a new priority claim and the applicable time limit for making the request according to Rule 56(3) EPC. If this is the case, then the requirement under Rule 56(3) EPC that priority be claimed is met.

From the above, it becomes clear that the Guidelines allow an applicant to add a priority claim after the date of filing and, subsequently or simultaneously, allow him to file missing parts of the description or missing drawings based on this later inserted priority claim. This is a broadening of Article 5(6)(b) PLT, which requires that, upon the incorporation of a missing part of the description or a missing drawing into an already filed application based on a priority application, the priority of this earlier application must have been claimed on the date one or more elements of the application were first received [see the discussion above].

Apart from deviating from a mandatory requirement of the PLT, this "leniency" in the Guidelines with respect to the later insertion of a priority claim represents a direct violation of Article 123(2) EPC, which provides that the European patent application may not be amended in such a way that it contains subject-matter which extends beyond the application as filed. The following two examples will clarify this.

\subsubsection{Example 1}

An applicant has invented a new method of preparing chemical compounds. He has filed a European patent application EP-A describing and claiming the new method and a new compound obtained by the method. In the priority year, more experiments are carried out and a second, new compound is prepared by the new method. A European patent application EP-B is filed, describing and claiming the second compound. The description

20 Ibid., Part A, Chapter II, \5.4, last paragraph.

${ }^{21}$ Ibid., Part A, Chapter II, \5.4.1. 
of this later application gives a brief account of the method for preparing the second compound.

Shortly after filing EP-B, the applicant realises that EP-B might suffer from insufficiency of disclosure [Article $83 \mathrm{EPC}$ ], because the method has not been described in full, the method in EP-A was not published before the filing date of EP-B and the method is not known from the common general knowledge. ${ }^{22}$ Within two months from the filing date of EP-B, the applicant files a passage from the description of EP-A containing the full disclosure of the preparation method as "missing part of the description" for inclusion into EP-B, at the same time adding to EP-B a priority claim to EP-A. This practice is currently sanctioned by the Guidelines. ${ }^{23}$

This way the applicant can add subject-matter to an application after the filing date to remedy an apparent insufficiency of disclosure of the application. As the priority claim to EP-A was not made on the filing date of EP-B, the "application as filed" had no "knowledge" of the "intention" of the applicant to add later on subject-matter to EP-B. This is a direct violation of Article 123(2) EPC, in the opinion of the author.

\subsubsection{Example 2}

An applicant has invented multiple solutions for a problem of a known product. As the applicant neither knows yet which solution will eventually be implemented in the products nor what his competitors will do, he files a number of patent applications in order to keep his options open. The applicant files a European patent application $\left(E_{1} P_{1}\right.$ $E P_{2}$ ) for each solution, each application describing and claiming a novel and improved product, implementing one of the solutions, in broad terms with detailed embodiments in the description.

Shortly after filing EP2, the applicant realizes that some of the embodiments described in $E P_{1}$ but not in $E P_{2}$, are also covered by the claims of $E P_{2}$. The applicant, within two months from the filing date of EP2 2 files a passage from the description of EP1 containing the text of the desired extra embodiments as "missing part of the description" into EP2, at the same time adding to $\mathrm{EP}_{2}$ a priority claim to $\mathrm{EP}_{1}$. Currently, this practice is also sanctioned by Guidelines. ${ }^{24}$ After receiving the search opinion [Rule 137(2) EPC], the applicant can file amended claims incorporating these embodiments as dependent claims in EP2.

As the priority claim to EP1 was not made on the filing date of EP2, the application "as filed" did not contain the extra embodiments. The later addition of the priority claim and filing missing parts completely contained in the priority application as permitted by

\footnotetext{
22 Ibid., Part C, Chapter IV, \11.2 and 11.3.

23 Ibid., Part A, Chapter II, \$5.4.1.

24 Ibid., Part A, Chapter II, $\$$ 5.4.1.
} 
Rule 56 EPC, allows the applicant to extend the subject-matter of his application after the filing date, contrary to Article 123(2) EPC.

\section{Conclusion}

The Guidelines Part A, Chapter II, \5.4.1 implementing Rule 56(3) EPC allowing an applicant to add a priority claim after the filing date of a European patent application and to file missing parts based on this earlier application, are in conflict with Article 123(2) EPC. It is recommended to change Rule 56(3) EPC to conform to Article 5(6)(b) PLT. Alternatively, the cited section of the Guidelines should be amended to stipulate that if the applicant desires to file missing items based on a priority application, the priority claim should have been made on the filing date of the application. This would avoid problems with extension of subject-matter with respect to the application "as filed" [Article 123(2) EPC] and would bring the EPC in line with the requirements of the PLT in respect of filing missing items.

In accordance with the requirements set by the PLT, the PCT requires that the priority claim be present "on the date on which one or more elements referred to in PCT Article 11(1)(iii) were first received by the receiving Office" if the applicant desires to include missing items without loss of the filing date.

\section{Additional comment on Rule 56 EPC}

It should be noted that the application of Rule $56 \mathrm{EPC}$ is not limited to the filing stage of a European patent application. For example, when the Receiving Section has decided not to re-date the application under Rule 56(2) or (5) EPC, but the search examiner is of the opinion that the subsequently filed missing parts are not "completely contained" in the priority document and/or the requirements of Rule 56(3) EPC are not fulfilled, the search should also take into account prior art which might become relevant for assessing novelty and inventive step of the subject-matter claimed if the application were re-dated pursuant to Rule 56(2) or (5) EPC. If, the Examining Division comes to the conclusion that the missing elements are not "completely contained" in the priority document, contrary to the original finding of the Receiving Section, it will communicate this to the applicant and notify him of the new date of filing. The Examining Division must also inform the applicant that, according to Rule 56(6) EPC, the missing drawings or parts of the description can still be withdrawn within one month from the communication from the Examining Division. ${ }^{25}$ If the applicant opts for withdrawal, the re-dating of the application will be deemed not to have been made.

In addition, the numbering of the paragraphs in Rule $56 \mathrm{EPC}$ is peculiar in that an earlier paragraph (4) refers to a later paragraph (6). It would be more logical to renumber the paragraphs of Rule 56 EPC as follows: (4) to (6), (5) to (4) and (6) to (5).

25 Note that the Guidelines Part C, Chapter VI, $\$ 3.1$ incorrectly write "... within two months from the date of notification of the new date of filing." 


\section{Chapter III - Filing date requirements under the EPC - filing by reference to a previously filed application ${ }^{1}$}

\section{Introduction}

The Patent Law Treaty (PLT) aims at harmonizing and streamlining formal procedures relating to national and regional patent applications and maintenance of patents. In spite of the goal of harmonization, the PLT does not establish a uniform procedure for all PLT Contracting Parties by leaving many requirements optional, allowing divergence in implementation between Parties. The European Patent Convention (EPC) was aligned with the PLT in the EPC 2000 revision. This Chapter compares the requirements for obtaining a date of filing when filing by reference to a previously filed application set by the PLT and its implementation in the EPC. The freedom in implementation has resulted in an increased complexity of the filing date requirements.

\section{Filing by reference to a previously filed application -Article 5(7) and Rule 2(5) PLT}

Article 5 of the PLT governs the requirements for the accordance of a date of filing. ${ }^{2}$ In particular, Article 5(1) PLT prescribes the elements of an application required for according a date of filing. Article 5(7)(a) PLT obliges a Contracting Party to accept, at the time of filing, the replacement of the description and any drawings in an application by $a$ reference to a previously filed application, subject to certain formal requirements. ${ }^{3}$

Rule 2(5) PLT provides two different types of requirements: ${ }^{4}$ obligatory requirements (indicated by "shall"), and optional requirements (indicated by "may require"). Each PLT Contracting Party can decide which optional requirements it incorporates into its law as compulsory requirements for the accordance of a filing date. Article 5(7)(b) PLT permits a Contracting Party to regard an application as not having been filed if the applicant fails to

1 This Chapter is an updated version of an earlier publication: Cees Mulder and Derk Visser:

"Filing date requirements under the EPC - filing by reference to a previously filed application" in epi Information 2|10, pp. 126-129.

See http://216.92.57.242/patentepi/en/Information/epi-information.php.

This article has been drafted by the present author Cees Mulder, and completed by him, taking into account valuable comments and suggestions by Derk Visser, who is therefore mentioned as co-author.

2 The Patent Law Treaty was adopted on 1 June 2000 at a Diplomatic Conference in Geneva; the Treaty entered into force on 28 April 2005.See WIPO Publication No. 258(E).

See http://www.wipo.int/treaties/en/ip/plt/.

3 "Explanatory Notes on the Patent Law Treaty and Regulations under the Patent Law Treaty adopted by the Diplomatic Conference on June 1, 2000" (prepared by the International Bureau), Diplomatic Conference for the adoption of the PLT, Document PT/DC/48 Prov. (November 2000), Note 5.23.

See http://www.wipo.int/meetings/en/details.jsp?meeting_id=4057.

4 Ibid., Note R2.05. 
comply with the obligatory and any optional requirements under Rule 2(5) PLT implemented as compulsory by a PLT Contracting Party. ${ }^{5}$

A PLT Contracting Party may decide that any remaining non-compulsory requirement in Rule 2(5) PLT is regarded as a formal requirement. Failure to meet a formal requirement does not result in a (retroactive) loss of the filing date but in the application being refused or considered withdrawn. ${ }^{6}$ The filing date accorded will not be affected by the loss of rights.

Rule 2(5)(a) PLT mentions two obligatory requirements and one optional requirement for the accordance of a filing date when filing an application by reference to a previously filed application:

(i) The reference to the previously filed application shall indicate that the description and any drawings are replaced by the reference to the previously filed application;

(ii) The reference shall also indicate the number of that application and the Office with which that application was filed;

(iii) A PLT Contracting Party may require that the reference also indicates the filing date of the previously filed application.

A PLT Contracting Party may decide which of the optional requirements mentioned in Rule 2(5)(b) PLT are made compulsory for the accordance of a filing date:

(iv) Filing a copy of the previously filed application and, where the previously filed application is not in a language accepted by the Office, a translation of that previously filed application, be filed with the Office within a time limit which shall be not less than two months from the date of receipt of the application;

(v) Filing a certified copy of the previously filed application with the Office within a time limit which shall be not less than four months from the date of the receipt of the application.

In addition, a PLT Contracting Party may make the optional requirement in Rule 2(5)(c) PLT compulsory for the accordance of a filing date:

(vi) Requiring that the previously filed application had been filed by the applicant or his predecessor or successor in title..$^{7-8}$

Ibid.; interpretation of Note 5.24 .

Cf. Article 6(8) PLT and the "Explanatory Notes on the Patent Law Treaty and Regulations under the Patent Law Treaty adopted by the Diplomatic Conference on June 1, 2000", Note 5.23.

7 This requirement is, e.g., implemented in, Article 15(1)(c)(ii) of The Patents Act (GB): "a reference ... to an earlier relevant application made by the applicant or a predecessor in title of his."

8 Also see: Summary Minutes of the Main Committee I (prepared by the International Bureau); $26^{\text {th }}$ session (Tuesday, June 1, 2000, morning); published in Records of the Diplomatic Conference for the Adoption of the Patent Law (Geneva, 2000) (WIPO Publication 327E), Item 2603. 
The requirements under Rule 2(5)(a) PLT must be complied with on the filing date of the application; any requirements under Rule 2(5)(b) PLT must be complied within the stated time limit. ${ }^{9}$

\section{Implementation of Rule 2(5) PLT in Rule 40 and 55 EPC}

Article 8o EPC 1973 did not permit filing by reference. The implementation of the PLT in the EPC 2000 has made this special type of filing possible. Thereto the requirements set out in Article 5 and Rule 2 PLT have been incorporated in Rule 40 EPC, implementing Article 80 EPC (all further references to the EPC are to the EPC 2000). Rule 40(1)(c) EPC states that "a description or reference to a previously filed application" is required for according a date of filing.

Rule 40(2) and (3) EPC deal with further requirements when the applicant refers to a previously filed application. In particular, Rule 40(2) EPC states that in this case the applicant must state the filing date and number of that application and the Office with which it was filed and indicate that the reference replaces the description and any drawings. Rule 40(2) EPC is a combination of the above-mentioned items (iii), (ii) and (i), respectively. In particular, the EPO has chosen to make the furnishing of the "filing date" of the previously filed application compulsory for a reference filing [see item (iii) above]. In addition, Rule 40(3) EPC requires an applicant to file a certified copy of the previously filed application within 2 months of filing the application. This requirement corresponds to item ( $v$ ) above, although the EPO appears not to comply with the prescribed time limit in Rule 2(5)(b)(ii) PLT which prescribes for the filing of the certified copy "a time limit which shall not be less than four months from the date of receipt of the application". However, when the applicant does not provide the certified copy of the previously filed application within two months of the filing date (and the certified copy is not already available to the EPO), he will be invited under Rule 55 EPC to file it within a non-extendable period of two months. ${ }^{10}$ Effectively, the EPO gives the applicant more than four months to file the certified copy of the previously filed application.

When an applicant files a European patent application by reference to a previously filed application, the EPO immediately accords the date of receipt of the reference filing as the date of filing (provided that all requirements of Rule 40(1) and (2) EPC have been met).

9 "Explanatory Notes on the Patent Law Treaty and Regulations under the Patent Law Treaty adopted by the Diplomatic Conference on June 1, 2000" (prepared by the International Bureau), Diplomatic Conference for the adoption of the PLT, Document PT/DC/48 Prov. (November 2000), Note 5.24 .

See http://www.wipo.int/meetings/en/details.jsp?meeting_id=4057.

10 Guidelines for Examination in the European Patent Office (April 2010); Part A, Chapter II, \$ 4.1.4i see http://www.epo.org/patents/law/legal-texts/guidelines.html. 
If the applicant has to rectify any deficiency for the accordance of a date of filing, e.g. because he omitted to indicate the number of the previously filed application or the Office where it was filed, the EPO will accord as the date of filing the date on which the required correction is received. Only in one situation, the correction of a deficiency will not result in a re-dating of the application. Where the application is filed by reference to a previously filed application and the applicant files the certified copy of the previously filed application within two months of the filing date as required by Rule 40(3) EPC, or where he complies with the subsequent invitation to file the certified copy within two months from a communication according to Rule 55 EPC, the application maintains its original date of filing. ${ }^{11}$ Hence, it appears contradictory to call the requirement of filing a certified copy a "filing date requirement", i.e. A requirement that must be complied with on the date of filing.

Since the EPO has chosen to make the filing of a certified copy of the previously filed application compulsory for the accordance of a filing date, the sanction on not providing the certified copy in due time is that the application will not be treated as a European patent application, as provided in Rule 55 EPC [cf. Article 9o(2) EPC]. This implies that the filing date which was initially accorded upon receiving the reference filing is taken away retroactively. ${ }^{12}$ Hence, the date of filing communicated to the applicant under Rule 55 EPC may be the original date of filing or the date of receipt of the missing item.

The sanction on late provision of an item in response to the Rule 55 EPC invitation, i.e. re-dating or no re-dating, is provided in the Guidelines only. ${ }^{13}$ It is doubtful whether the mention of a sanction merely in the Guidelines is sufficient as legal basis, because, as a matter of principle, sanctions affecting the application or patent must have a legal basis in the EPC. Moreover, the broad possibilities of amendment of the Guidelines may not provide the desired legal certainty for parties about an important issue as the date of filing.

In the last sentence of Rule 40(3) EPC reference is made to Rule 53(2) EPC applying mutatis mutandis. This implies that the EPO will include a copy of the previously filed application into the file where this application is already available to the EPO under the conditions specified by the President, ${ }^{14}$ and the applicant need not file a copy. The conditions appear to be the same as for availability of a priority document to the EPO. ${ }^{15}$ However, the Guidelines state that the availability of US applications is "subject to the document exchange agreement with the USPTO". ${ }^{16}$ Whereas a US provisional or non-provisional patent application is regarded as available under Rule 53(2) EPC when

\footnotetext{
11 Ibid., Part A, Chapter II, $\ 4$ 4.1.5.

12 Ibid., Part A, Chapter II, $\$$ 4.1.5.

13 Ibid., Part A, Chapter II, $\$ 4.1 .5$

${ }_{14}$ Ibid., Part A, Chapter II, $\$$ 4.1.3.1. Also see Rule 4(3) PLT.

15 Ibid., Part A, Chapter III, \$6.7.

16 Ibid., Part A, Chapter II, $\$ 4.1 .3 .1$ (e) and Chapter III, $\$ 6.7$ (v).
} 
claiming priority, ${ }_{1}^{17}$ this application is not regarded as available Rule 40 (3) EPC when filing by reference. Additionally, applications filed with receiving Offices other than the EPO are regarded as not available. For example, when filing a divisional by reference to a Euro-PCT application filed with the USPTO as receiving Office, the applicant must file a certified copy of the Euro-PCT application with the EPO.

It should be noted that the period of more than four months to file a copy of the previously filed application may be too short for procuring a certified copy from some patent Offices. To avoid losing the date of filing, it is recommended to file by reference only when the applicant has the certified copy available on the date of filing or when the EPO will include the copy into the file. An applicant may even consider using filing by reference only when the EPO will include a copy of the previously filed application into the file, because the advantage of filing by reference may not outweigh the expense and additional risk of having to file a certified copy.

Rule 40(3) EPC contains the additional requirement that the applicant must file a translation of the previously filed application where that application is not in an official language of the EPO. This requirement corresponds to item (iv) above.

Although both the filing of the copy and the translation of the previously filed application are mentioned in one sentence of the optional requirement in Rule 2(5)(b) PLT [see item (iv) above], the EPO has decided to treat these requirements differently. ${ }^{18}$ Whereas the EPO has made the filing of the copy compulsory for the accordance of the date of filing, the filing of the translation is considered as an issue of formalities. In spite of the fact that the filing of the translation is mentioned in Rule 40 EPC, titled "Date of filing", it is not regarded as a filing date requirement, because Rule 55 EPC does not refer to it. ${ }^{19}$ This interpretation can be derived from the Guidelines. ${ }^{20}$

Hence, if the applicant does not furnish a required translation of the previously filed application, the date of filing already accorded to his application is retained. In the case of a missing translation pursuant Rule 40 (3) EPC, the EPO will not send the applicant a communication under Rule 55 EPC but a communication under Rule 58 EPC, informing him that the required translation has not been filed [Rule 57(a) EPC referring to Rule 40(3) $E P C$, second sentence] and inviting him to file the translation within a non-extendable

17 Official Journal of the European Patent Office, 2009, p. 236.

${ }_{18}$ Cf. "Filing date requirements under the EPC - an option to extend subject-matter?" by Cees Mulder and Derk Visser in epi Information 2|10, pp. 44-48. An updated version of this article is included in Chapter II of this thesis.

See http://216.92.57.242/patentepi/en/Information/epi-information.php.

19 In Rule 55 EPC reference is made to the first sentence of Rule 40(3) EPC relating to the filing of a certified copy of the previously filed application. However, Rule 55 EPC does not refer to the second sentence of Rule 40(3) EPC relating to the filing of a translation of the previously filed application.

20 Guidelines for Examination in the European Patent Office (April 2010); Part A, Chapter II, \$4.1.4, last paragraph and Chapter III, $\ 14$. 
period of two months. Non-compliance results in the European patent application being deemed withdrawn under Article 14(2) EPC [ $c f$. "different legal consequence" in Article 9o(5) EPC]. ${ }^{21}$

When filing by reference, care must be taken to provide the correct application number of the previously filed application. A wrong number is (probably) not correctable, because a change in number amounts to replacing the filed application by another application, which was prohibited by $\mathrm{G}_{2} / 95$. In contrast, an incorrect application number of a priority application when filing a complete application can be corrected under Rule 53(3) EPC within at least four months from the date of filing. Similarly, a missing or wrong number of the parent application when filing a complete divisional application can be corrected under Rule 58 EPC. ${ }^{22}$

About $0.8 \%$ of all European applications filed with the EPO since the entry into force of the EPC 2000 has been filed by reference; $80 \%$ of these were divisional applications. Since $5 \%$ of all filed applications are divisional applications, only one in eight divisional applications is filed by reference. The limited use of this new filing option in the EPC 2000 is explicable.

Filing by reference is advantageous when transmitting the application by fax, since the description and figures need not be sent anymore. However, when using electronic filing, the effort to include a copy of the application is relatively small. Hence, the advance in technology away from fax transmission appears to have taken away the main advantage of filing by reference. Moreover, filing the complete application does not have the disadvantages of the risk of uncorrectable errors and the obligation to provide a certified copy of the previously filed application. If filing by reference were optional in the PLT, filing by reference in Rule 4O(1)(c) EPC and, consequently, Rule 4O(2) and (3) EPC should be deleted from the EPC, thereby simplifying the procedure and removing the inherent confusion around the second sentence of Rule 40(3) EPC.

For the sake of completeness, the EPO has not implemented the optional requirement under the above item ( $\mathrm{vi}$ ) that the previously filed application need be filed by the applicant or his predecessor or successor in title. This raises the question whether the right to the patent may be transferred from a predecessor who filed the previous application to the present applicant after the date of filing by reference. In the case of a priority claiming application filed by another applicant than the priority application, the claim to priority must be transferred before filing the priority claiming application, according to EPO case law. ${ }^{23}$ The same applies to filing a divisional application. ${ }^{24}$

21 Ibid., Part A, Chapter III, $\ 14$.

22 Ibid., Part A, Chapter IV, \$1.3.2.

23 Ibid., Part A, Chapter III, \$6.1 and decision of the Legal Board of Appeal J 19/87; see http://legal.european-patent-office.org/dg3/biblio/j87001geu1.htm.

24 Decision Legal Board of Appeal J 2/01, see http://legal.european-patent-office.org/dg3/biblio/jo100ozep1.htm 


\section{Conclusion}

The PLT is designed to streamline and harmonize formal requirements of national and regional patent Offices for the filing and processing of national and regional patent applications, the maintenance of patents and certain additional requirements related to patents or patent applications. One of the crucial issues of a patent application is the accordance of a filing date. The mix of obligatory and optional requirements in the PLT and the freedom of choice for a PLT Contracting Party to implement (part of the) optional requirements as compulsory into its national law allows widely varying implementations in national or regional patent laws (compare e.g. the EPC and the PCT), leading away from the intended harmonization.

Although the implementation of filing date requirements in the EPC 2000 closely follows the PLT provisions, it has resulted in a system that is substantially more complicated than under the EPC 1973, defying the aim of streamlining the PLT.

Filing by reference appears already to have become outdated as a result of advances in transmission technology and should not be regarded as a preferred option for filing a patent application with the EPO. Therefore, the option of "filing by reference" could be abolished in Rule 4O(1)(c) EPC, thereby at the same time deleting Rule 4O(2) and (2) EPC. 
This page was left blank intentionally. 


\section{Chapter IV - Filing date requirements under the PCT - Alignment with the PLT? ${ }^{1}$}

\section{Introduction}

In June 2000, the Diplomatic Conference for the Adoption of the Patent Law Treaty, convened by the World Intellectual Property Organization (WIPO) and encompassing 140 States, adopted the Patent Law Treaty; the PLT entered into force in April $2005 .{ }^{2}$ The aim of the PLT is "to harmonize and streamline", on a world-wide basis, formal procedures relating to national and regional patent applications and the maintenance of patents. In particular, the PLT provides maximum sets of requirements that the Office of a Contracting Party could apply. This means that a Contracting Party is free to provide for requirements that are more generous from the viewpoint of applicants and owners. The provisions of the PLT apply to national and regional patent applications and patents as well as to international applications under the PCT once these applications have entered the "national phase."

During the past few years the main features of the Patent Law Treaty have been implemented in a number of national patent laws and in regional patent treaties. During the EPC 2000 revision, the European Patent Convention was adapted to the PLT. ${ }^{6}$

1 This Chapter is an updated version of an earlier publication: Cees Mulder: "Filing date requirements under the PCT - Alignment with the PLT?" in The WIPO Journal, Volume 2, Issue 2, pp. 173-195 (2011).

See http://www.wipo.int/about-wipo/en/wipo journal/.

2 Patent Law Treaty, WIPO Publication No. 258(E).

See http://www.wipo.int/treaties/en/ip/plt/.

3 "Revision of the European Patent Convention (EPC 2000). Synoptic presentation EPC 1973/2000

- Part I: The Articles", EPO Official Journal 2007, Special Edition No. 4; comment in relation to Article 120 EPC.

See http://www.epo.org/patents/law/legal-texts/journal/2007.html.

4 "Revision of the European Patent Convention (EPC 2000). Synoptic presentation EPC 1973/2000 - Part II: The EPC Implementing Regulations", EPO Official Journal 2007, Special Edition No. 5i comment in relation to Rule 59 EPC.

See http://www.epo.org/patents/law/legal-texts/journal/2007.html.

5 Cees Mulder and Derk Visser: "Filing date requirements under the EPC - an option to extend subject-matter?" published in epi Information 2|10, pp. 44-48. An updated version of this article is included in Chapter II of this thesis.

See http://www.patentepi.com/patentepi/en/Information/epi-information.php.

6 Cees Mulder and Derk Visser: "Filing date requirements under the EPC - filing by reference to a previously filed application", epi Information 4|10, pp. 126-129. An updated version of this article is included in Chapter III of this thesis.

See http://www.patentepi.com/patentepi/en/Information/epi-information.php. 


\section{Main purpose of this chapter}

Both the Patent Law Treaty (PLT) and the Patent Cooperation Treaty (PCT) are international treaties on patent law. The PCT cannot become a "Contracting Party" to the PLT. ${ }^{7}$ So there is, ex lege, no reason for the PCT to comply with the requirements set by the PLT, e.g. with respect to the accordance of a date of filing.

A main feature of the PLT is that it provides standardized formality requirements for patent applications which are filed with a national or regional patent Office. Instead of defining these requirements again or differently in the PLT, it was decided to incorporate by reference the provisions of the PCT and its Regulations, wherever appropriate, into the $\mathrm{PLT}$. The main reason for this is that the PCT already regulates in detail the formality requirements with respect to patent applications. ${ }^{8}$

The question may arise as to why a (new) Patent Law Treaty was needed. The answer is that the PCT harmonizes formalities only with respect to international applications. The requirements applied by Offices to national and regional applications, as well as to international applications having entered the national phase, still vary considerably. The main concern of the drafters of the PLT was to avoid creating another internationally-applicable standard different from the PCT, since more than 140 countries that are members of the PCT already apply the standards under the PCT to international applications. ${ }^{9}$

As the PLT is directly linked to the PCT, it seems "strange" that the PCT does not "comply" with the basic requirements of the PLT, e.g. with respect to the accordance of the international filing date. As described in this chapter, the PCT was modified in view of the adoption of the PLT but mainly to satisfy requirements of national law necessary for national processing. Apart from this, attempts have been undertaken to improve alignment between the PCT and the PLT, but this was largely impossible because amendment of the Articles of the PCT was regarded necessary. "Simply" amending the PCT Regulations to provoke alignment, thereby "bending" the PCT Articles, was often considered a bridge too far in discussions of the Working Group on Reform of the PCT.

In this Chapter the degree of alignment of the PCT with the PLT is investigated in relation to the filing date requirements under the $P C T$. In particular, the differences between the PLT and the PCT are identified. An analysis of the differences, problems derived from them and possible solutions will be given.

7 Cf. Article 20 PLT.

8 "Basic Features to the Patent Law Treaty (PLT)" (November 2006), Items 13-19. See: http://www.wipo.int/patent-law/en/plt.htm

9 Ibid., Item 14. 


\section{Relationship between the PLT and the PCT}

The Patent Law Treaty (PLT) is connected to the Patent Cooperation Treaty (PCT). Although the PLT is primarily focuses on national and regional patent applications, it incorporates by reference the standards prescribed by the PCT as to the form and contents of international applications [ $c f$. Article 6(1) PLT]. These procedural and administrative requirements include the form and contents of national and regional patent applications, the type of translations of documents and the evidence which an applicant may be required to provide to an Office in the course of processing his application. In view of the adoption of the PLT, the PCT Regulations were amended in the spirit of the PLT, enabling applicants, when filing an international application, to satisfy in a simplified manner a number of requirements of national law which have to be met when the international application, at a later date, enters the national phase before the national Office of a PLT Contracting Party. ${ }^{10}$ The PCT Assembly decided that these amendments to the PCT Regulations would enter into force on 1 March 2001. ${ }^{11}$

Article 3(1) PLT specifies the applications and patents to which the PLT applies: "national and regional applications for patents for invention and for patents of addition". The terms "national and regional applications for patents for invention" and "applications for patents of addition" are to be construed in the same sense as these terms in PCT Article 2(i). ${ }^{12}$ Under Article 3(1)(a)(i) PLT, the PLT also applies to those types of applications for patents for invention and for patents of addition, which can be filed as international applications under the PCT. ${ }^{13}$

Article 3(1)(b) PLT applies to Contracting Parties which are also party to the PCT. The phrase "Subject to the provisions of the Patent Cooperation Treaty" is included in Article 3(1)(b) PLT to ensure that the provisions of the PCT continue to apply to international applications in the "national phase." For example, a filing date accorded to an international application under PCT Article $11(2)(b)^{14}$ cannot be challenged by the

10 "Proposed Amendments of the PCT Regulations and modifications of the PCT Administrative Instructions, relating to the draft Patent Law Treaty", PCT Union, Document PCT/A/28/2 (January 2000), Item 2.

See http://www.wipo.int/meetings/en/details.jsp?meeting_id=4001.

11 Ibid., Item 46.

12 "Explanatory Notes on the Patent Law Treaty and Regulations under the Patent Law Treaty adopted by the Diplomatic Conference on June 1, 2000" (prepared by the International Bureau), Diplomatic Conference for the adoption of the PLT, Document PT/DC/48 Prov. (November 2000), Note 16.01.

See http://www.wipo.int/meetings/en/details.jsp?meeting_id=4057.

13 Ibid., Note 3.04.

14 PCT Article 11(2)(b) refers to the situation where the receiving Office did accord a later international filing date due to the applicant complying with an invitation from the receiving Office stating that he did not fulfill the requirements of PCT Article 11(1), e.g. because of the late filing of at least one claim. 
applicant, once that application has entered the national phase, on the grounds that the application would be entitled to an earlier filing date under Article 5(1)(a) PLT. ${ }^{15}$

The purpose of Article 6(1) PLT is to apply, to the extent possible, the requirements relating to the form or contents of international applications under the $\mathrm{PCT}$ to national and regional applications. ${ }^{16} \mathrm{It}$ is implicit that the expression "form or contents of an application" in Article 6(1) PLT is to be construed in the same manner as the expression in PCT Article 27(1) stating that no national law may require compliance with requirements relating to the "form or contents of the international application" different from or additional to those which are provided for in the PCT and its Regulations. ${ }^{17}$

Article 6(1)(i) PLT prohibits a Contracting Party from imposing requirements in respect of the form or contents of a national or regional application that are more strict than those applicable to international applications under the PCT. ${ }^{18}$ In addition, Article 6(1)(i) PLT permits a Contracting Party to require that a national or regional application complies with any requirements relating to the "form or contents" that any PCT Contracting State is allowed to apply after entry of the international application in the "national phase" ${ }^{19}$

In preparation for the Diplomatic Conference for the adoption of the PLT, the International Bureau investigated how future changes to the PCT could be incorporated by reference into the PLT. This principle, which was not explicitly incorporated into the provisions of the Basic Proposal of the $\mathrm{PLT}_{1}{ }^{20}$ is implicitly assumed in order to make the interface between the PLT and the PCT viable over time. The International Bureau could not identify any identical or analogous provisions in other international treaties. ${ }^{21-22}$

15 "Explanatory Notes on the Patent Law Treaty and Regulations under the Patent Law Treaty adopted by the Diplomatic Conference on June 1, 2000", Document PT/DC/48 Prov. (November 2000), Note 3.07.

16 lbid., Note 6.01.

17 Ibid., Note 6.02.

18 Ibid., Note 6.06 .

19 Ibid., Note 6.07.

20 "Basic Proposal for the Patent Law Treaty" (submitted by the Director General of WIPO), Diplomatic Conference for the adoption of the PLT, Document PT/DC/3 (November 1999). See http://www.wipo.int/meetings/en/details.jsp?meeting_id=4057.

21 "Results of the $28^{\text {th }}\left(16^{\text {th }}\right.$ Extraordinary) Session of the PCT Assembly, March 13 to 17, 2000; Issues for Possible Discussion at the Diplomatic Conference" (prepared by the International Bureau), Diplomatic Conference for the adoption of the PLT, Document PT/DC/6 (April 2000), Item 14 .

See http://www.wipo.int/meetings/en/details.jsp?meeting_id=4057.

22 An example of such "incorporation by reference" in the field of intellectual property is found in PCT Article 62(3), which states that the "provisions of Article 24 of the Stockholm Act of the Paris Convention" apply to the PCT. This appears to cause no problem because membership to the PCT is, in principle, limited to countries party to the Paris Convention [Cf. PCT Article 62(1) and Article 1(1) Paris Convention]. 
The International Bureau indicated that discussion would be needed at the Diplomatic Conference on the international law implications of the automatic incorporation of future modifications of the PCT and the PCT Regulations into the PLT, in particular in respect of PLT Contracting Parties which are not also PCT Contracting States. ${ }^{23-24}$ As these non-PCT Contracting States are not represented in the PCT Assembly, they would therefore have no voice in future changes to the PCT Regulations. A further difficulty is posed by the fact that future changes to the PCT Administrative Instructions should also be automatically incorporated into the PLT, even though these changes are promulgated by the Director General of WIPO after consultation with Offices and Authorities which have a direct interest in the proposed modifications, but without express approval by the PCT Assembly. ${ }^{25}$

Various options to deal with this problem were discussed in a document prepared by the International Bureau ${ }^{26}$ and discussed at the Diplomatic Conference for the adoption of the PLT, which, eventually, resulted in the adoption of Article 16 and $17(2)(v) P L T .{ }^{27}$ In addition, an "Agreed Statement" was formulated during the PLT Diplomatic Conference consolidating the relationship between the PLT and the PCT. ${ }^{28}$

The effect of Article 16(1) PLT is that any revisions, amendments and modifications to the PCT (made after June 2, 2000) will only apply for the purpose of the PLT if two conditions are satisfied. First, the revision, amendment or modification to the PCT must be consistent with the Articles of the PLT. Second, that revision, amendment or modification to the PCT must be adopted by the PLT Assembly, for the purposes of the PLT, by a majority of three-fourths of the votes cast. Accordingly, future changes to the PCT will not apply for the purposes of the PLT unless and until they are formally adopted

Another example is that Article 2.1 of the TRIPs Agreement incorporates by reference Articles 1 through 12 and 19 of the "Paris Convention (1967)" (Stockholm Act). However, the TRIPS Agreement does not incorporate future changes to the Paris Convention.

Additional examples can be found in: "Results of the $28^{\text {th }}\left(16^{\text {th }}\right.$ Extraordinary) Session of the PCT Assembly, March 13 to 17, 2000; Issues for Possible Discussion at the Diplomatic Conference" (prepared by the International Bureau), Diplomatic Conference for the adoption of the PLT, Document PT/DC/6 (April 2000), Item 14.

${ }_{23}$ Currently (November 1, 2011) all PLT members are also Contracting State to the PCT.

24 "Results of the $28^{\text {th }}$ (16 $6^{\text {th }}$ Extraordinary) Session of the PCT Assembly, March 13 to 17, 2000; Issues for Possible Discussion at the Diplomatic Conference" (prepared by the International Bureau), Diplomatic Conference for the adoption of the PLT, Document PT/DC/6, Item 16. Ibid., Item 15.

26 Ibid., Item 17-23.

27 Article 16 PLT as currently in the PLT was not present in the "Basic Proposal for the Patent Law Treaty", see Document PT/DC/3.

28 "Patent Law Treaty, Regulations under the Patent Law Treaty and Agreed Statements by the Diplomatic Conference" (adopted by the Diplomatic Conference on June 1, 2000), Diplomatic Conference for the adoption of the PLT, Document PT/DC/47 (June 2000), Agreed Statements, Item 2.

See http://www.wipo.int/meetings/en/details.jsp?meeting_id=4057. 
by the PLT Assembly. ${ }^{29}$ In addition, Article 16(2) PLT relates to provisions of the PCT ("transitional provisions"), and by virtue of which a revised, amended or modified provision of the PCT does not apply to a State party to the $\mathrm{PCT}$, or to an Office acting for such a State, for as long as that revised, amended or modified provision is incompatible with the law applied by that State or Office..$^{30}$

\section{Alignment of the Patent Cooperation Treaty with the Patent Law Treaty}

In view of the adoption of the Patent Law Treaty and the relationship between the PLT and the PCT, the "Working Group on Reform of the PCT" discussed proposals designed to align the PCT with the requirements of the PLT. There was wide agreement as to a number of general observations made by various Delegations: ${ }^{31}$

- the principles of the PLT should so far as possible be taken up in the PCT in order to achieve the same benefits for applicants and Offices in the filing and processing of international applications as would be available for national applications;

- certain features of the PCT system differed from national and regional patent systems; some aspects of the PLT were less relevant than others in the context of the PCT system;

- while some provisions of the PLT could be implemented readily by changing the PCT Regulations, others would require changing the PCT Articles; some proposed amendments to the PCT Regulations raised difficulties of possible inconsistency, to varying degrees, with the PCT Articles, for example, in providing for the accordance of an international filing date where no claims were present in an international application;

○ priority should be given by the Working Group on Reform of the PCT to those matters which would result in the greatest and most immediate practical benefits for users, having regard also to the degree of complexity involved and to workload implications for Offices and Authorities; for example, priority might be given to the following:

- provisions for restoration of the priority right;

- relief when time limits were missed, especially the time limit for entering the national phase.

29 "Explanatory Notes on the Patent Law Treaty and Regulations under the Patent Law Treaty adopted by the Diplomatic Conference on June 1, 2000", Document PT/DC/48 Prov. (November 2000), Note 16.01.

30 Ibid., Note 16.03.

31 "Summary of the session" - "Changes Related to the PLT" (prepared by the Chair), Document PCT/R/WG/1/9 (November 2002), Item 21.

See http://www.wipo.int/meetings/en/details.jsp?meeting_id=4446. 
With respect to issues in relation of the filing of an international application, the following amendments in the Regulations under the PCT were, eventually, adopted or amended: ${ }^{32}$

1) Filing missing parts of the description or missing drawings [Article 5(6) PLT; PCT Article 11 and Rule 20.5 EPC]; ${ }^{33}$

2) Restoration of the right to priority [Article 13(2) PLT; PCT Rule 26bis.3].

The item:

3) Addition or correction of a priority claim [Article 13(1) PLT; PCT Rule 26bis.1]

was already present in the PCT. In fact, Article 13(1) PLT was modeled after PCT Rule 26bis.1, permitting the applicant to add or correct a priority claim, on or after the filing date, to an application which could have claimed the priority of an earlier application but did not do so. ${ }^{34}$

The following items in the PCT have not or only partly been aligned with the PLT:

4) Requirements for according an international filing date to an international application [Article 5(1) PLT; PCT Article 11(1) and Rule 20];

5) Filing a description and/or drawings by a reference to another application [Article 5(7) PLT; no direct equivalent in the PCT].

In this Chapter, the requirements in relation to the accordance of an international filing date (items 4, 5 and 1, respectively) are investigated, elucidating the "misalignment" between provisions of the PLT and provisions of the PCT.

\section{Inconsistencies in provisions dealing with filing date requirements}

\subsection{Filing date requirements - Article 5 PLT}

Article 5 of the PLT governs the requirements for the accordance of a date of filing. In particular, Article 5(1) PLT prescribes the elements of an application to be filed for the purpose of according a date of filing. First, the Office receiving the application documents needs to be satisfied that the elements that it has received are intended as an application for a patent [Article 5(1)(a)(i) PLT]. Second, the Office must be provided with indications which identify the applicant and/or allow the applicant to be contacted.

32 On April 1, 2007, the Regulations under the PCT were amended to better align the PCT with requirements of the PLT.

33 Provisions concerning the furnishing of missing parts of the description of missing drawings already existed before the Reform of the PCT in view of the PLT (April 2007). In the context of aligning the PCT with the PLT, the existing provisions were amended.

34 "Explanatory Notes on the Patent Law Treaty and Regulations under the Patent Law Treaty adopted by the Diplomatic Conference on June 1, 2000", Document PT/DC/48 Prov. (November 2000), Note 13.01. 
Instead of such indications, the Office may accept evidence allowing the identity of the applicant to be established or allowing the applicant to be contacted by the Office [Article 5(1)(a)(ii) and (1)(c) PLT]. Third, the Office must have received a disclosure of the invention, either in the form of what appears to be a description or, where permitted, a drawing in place of that description [Article 5(1)(a)(iii) and (1)(b) PLT]. In addition, Article 5(7) PLT obliges a Contracting Party to accept, at the time of filing, the replacement of the description and any drawings in an application by a reference to a previously filed application, subject to certain formal requirements. ${ }^{35}$

A PLT Contracting Party is obliged to accord a date of filing to an application which complies with the requirements of Article 5 PLT. Since the list of elements under Article 5(1) PLT is exhaustive, a PLT Contracting Party is not permitted to require any additional elements for a filing date to be accorded. ${ }^{36}$ In particular, it is not permitted to require that the application contains one or more claims, compliance with formal requirements (e.g. that handwritten applications are not accepted), use of a prescribed language, or payment of a filing fee. ${ }^{37}$

\subsection{Filing date requirements - PCT Article 11}

PCT Article 11(1) prescribes the requirements for the accordance of an international filing date: $:^{8-39}$

The receiving Office shall accord as the international filing date the date of receipt of the international application, provided that that Office has found that, at the time of receipt:

(i) the applicant does not obviously lack, for reasons of residence or nationality, the right to file an international application with the receiving Office,

(ii) the international application is in the prescribed language,

(iii) the international application contains at least the following elements:

(a) an indication that it is intended as an international application,

(b) the designation of at least one Contracting State,

(c) the name of the applicant, as prescribed,

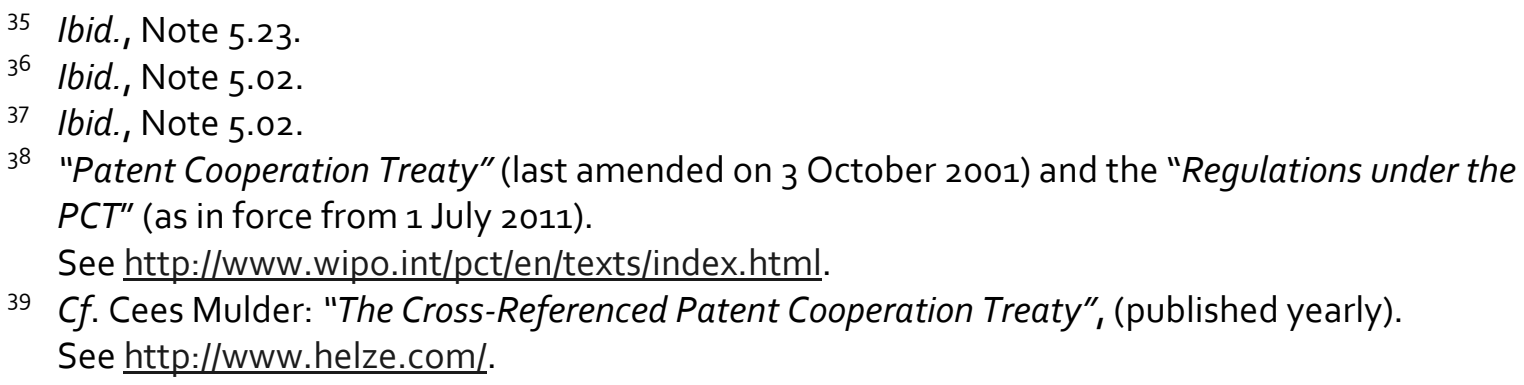


(d) a part which on the face of it appears to be a description,

(e) a part which on the face of it appears to be a claim or claims.

\subsection{Filing date requirements - Differences / matter of concern}

\subsubsection{Right to file an international application}

The requirements under PCT Article 11(1)(i) ("right to file") are different from those under the PLT, because the accordance of a filing date in Article 5(1) PLT is not dependent on the nationality or residence of the applicant. As, e.g., Argentina is not a PCT Contracting State, an international filing date will not be accorded when an Argentinean national living in Argentina files an international application. Pursuant PCT Article 9(2), the PCT Assembly may decide to allow residents and nationals of any country party to the Paris Convention which is not party to the PCT, to file international applications. No such decision has been taken..$^{40}$

If an applicant files the international application at a non-competent receiving Office, there is a fail-save arrangement in PCT Rule 19.4(a)(i) providing that the application will be forwarded to the International Bureau and is considered to have been received by that receiving Office on behalf of the International Bureau as receiving Office under PCT Rule 19.1(a)(iii). In this situation, PCT Article 11(1)(i) is in alignment with the requirements of the PLT.

40 PCT Applicant's Guide, International Phase, Item 6.036: If the indications of the applicant's residence and nationality as stated in the request do not support the applicant's right to file an international application, that is, if the applicant appears not to be (or, where there are two or more applicants, none of the applicants appears to be) a resident or national of a Contracting State, there is prima facie a defect under PCT Article 11(1)(i) and the receiving Office issues an invitation accordingly to correct that defect. In such a case, it may be that the applicant is able to show that he had, on the date on which the international application was actually received by the receiving Office, the right to file an international application with that receiving Office. In those circumstances, the applicant should submit evidence to the receiving Office accordingly, together with a proposed correction of the indications concerning his residence and/or nationality. If the receiving Office is satisfied, on the basis of that evidence, of the applicant's right to file the international application, the invitation to correct the defect under PCT Article 11(1)(i) will be considered to be an invitation to correct a defect under PCT Article 14(1)(a)(ii) and Rule 4.5 in the prescribed indications concerning the applicant's residence and/or nationality, and the indications may be corrected accordingly. If such a correction is made, no defect will be considered to exist under PCT Article 11(1)(i), and the defect will thus not prevent the accordance of the actual date of receipt of the international application as the international filing date. Note, however, that the United States Patent and Trademark Office as receiving Office has stated that it will not apply the procedure outlined above.

See http://www.wipo.int/pct/en/appguide/index.jsp. 


\subsubsection{Language of filing an international application}

The requirement under PCT Article 11(1)(ii) ("prescribed language") is, in principle, different from that under Article 5(1) PLT. However, the fail-save arrangement of PCT Rule 19.4(a)(ii) provides that, when an international application is filed in a language not accepted by the receiving Office, that application will be forwarded to the International Bureau and is considered to have been received by that receiving Office on behalf of the International Bureau as receiving Office under PCT Rule 19.1(a)(iii). ${ }^{41}$ The International Bureau of WIPO accepts international applications filed in "any language"..$^{2}$

\subsubsection{Intended as an international application}

The requirement under PCT Article 11(1)(iii)(a) ("indication international application") is in alignment with that under Article 5(1)(i) PLT.

\subsubsection{Designation of at least one Contracting State}

The requirement under PCT Article 11(1)(iii)(b) ("designation of States") is, in principle, different from that under Article 5(1) PLT. However, the adoption of PCT Rule 4.9 implies an automatic and all-inclusive designation of all PCT Contracting States upon filing an international application. ${ }^{43}$

\subsubsection{Identification of applicant}

The requirement under PCT Article 11(1)(iii)(c) ("applicant") is different from that under Article 5(1)(ii) PLT. PCT Rule 20.1(b) gives a definition of this requirement:

For the purposes of Article 11(1)(iii)(c), it shall be sufficient to indicate the name of the applicant in a way which allows the identity of the applicant to be established even if the name is misspelled, the given names are not fully indicated, or, in the case of legal entities, the indication of the name is abbreviated or incomplete.

This definition only deals with the situation that the name of the applicant is more or less known but contains some formalities error ("misspelled" or incomplete address) which may be corrected upon invitation by the receiving Office (such correction will not result in a re-dating of the international application). However, the definition in PCT Rule 20.1(b) does not address the situation "allowing the applicant to be contacted" as prescribed in Article 5(1)(ii) PLT. This relates to situations where, e.g., only the name and address of the patent attorney of the applicant and/or only the address or fax number of

${ }_{41}$ "Summary of the session" - "Changes related to the PLT: Language of the International Application and Translations" (prepared by the Chair), Working Group on Reform of the PCT, Document PCT/R/WG/2/12 (May 2002), Item 27.

See http://www.wipo.int/meetings/en/details.jsp?meeting_id=4554.

42 PCT Applicant's Guide - International Phase - Annex C - International Bureau of the WIPO. See http://www.wipo.int/pct/en/appguide/index.jsp\#l.

43 "Summary of the session" - "Changes Related to the PLT" (prepared by the Chair), Document PCT/R/WG/1/9 (November 2002), Items 12-13. 
the attorney are known. The receiving Office contacting the attorney and through him the applicant is not encompassed in the definition of PCT Rule 20.1(b). PCT Rule 20.1(b) could easily be adapted so as to bring it into alignment with Article 5(1)(ii) PLT. ${ }^{44}$

\subsubsection{Description}

The requirement under PCT Article 11(1)(iii)(d) ("description") is in alignment with that under Article 5(1)(iii) PLT.

\subsubsection{Claims}

The requirement under PCT Article 11(1)(iii)(e) ("claim or claims") is different from that under Article 5(1) PLT. For the accordance of a date of filing under the PLT, it is not permitted to require that the application contains one or more claims. ${ }^{45}$

As mentioned earlier, the PCT cannot become not a "Contracting Party" to the PLT, so there is no obligation to comply with the requirements of the PLT. However, attempts were undertaken in the Working Group on the Reform of the PCT to align the PCT with the PLT with respect to the compulsory presence of claims as prescribed in PCT Article 11(1)(iii)(e). In particular, the Working Group on Reform of the PCT indicated that it would be prepared to consider other ways of dealing with international applications having no claims pending revision of the PCT Articles. ${ }^{46}$

A way to circumvent the requirement of PCT Article 11(1)(iii)(e) is to regard claims as a "legal fiction". ${ }^{47}$ A proposal to this effect, prepared in great detail by the International Bureau, included the introduction of a suitably-worded pre-printed statement to be included in the Request Form [PCT/RO/101] as well as the presence of "claim-like" wording in the description. To this end a new item would be added to PCT Rule $20.4{ }^{48}$ worded as follows:

44 "Changes related to the Patent Law Treaty (PLT): Other PLT-Related Changes" (prepared by the International Bureau), Working Group on Reform of the PCT, Document PCT/R/WG/2/6 (March 2002), Item 21.

See http://www.wipo.int/meetings/en/details.jsp?meeting_id=4554.

45 "Explanatory Notes on the Patent Law Treaty and Regulations under the Patent Law Treaty adopted by the Diplomatic Conference on June 1, 2000", Document PT/DC/48 Prov. (November 2000), Note 5.02.

46 "Summary of the session" - "Changes Related to the PLT" (prepared by the Chair), Document $\mathrm{PCT} / \mathrm{R} / \mathrm{WG} / 1 / 9$ (November 2002), Item 26.

47 "Changes related to the Patent Law Treaty (PLT): Absence of 'Formal' Claims" (prepared by the International Bureau), Working Group on Reform of the PCT, Document PCT/R/WG/2/8 (March 2002).

See http://www.wipo.int/meetings/en/details.jsp?meeting_id=4554.

$4^{8}$ After the Reform of the PCT in view of the PLT (April 2007), such an item would have been included in PCT Rule 20.1. 
"For the purposes of Article 11(1)(iii)(e), it shall be sufficient that there is wording in any part of the international application which makes it clear what is the matter for which protection is sought."

This "claim-like" wording would be sufficient to constitute "a part which on the face of it appears to be a claim or claims" and, hence, support the accordance of an international filing date. It should be noted that PCT Article 11(1)(iii)(e) does not prescribe where the part that appears to be a claim is to be included in the international application and, in addition, does not require that the claims be expressly identified as such. Where compliance with PCT Article 11(1)(iii)(e) relies solely on either of these two possibilities, the international application would be considered to contain a formal defect under PCT Article 14, which can be remedied by the furnishing of "formal" claims as a correction under PCT Rule $26.4^{49}$ The later furnishing of claims would be consistent with Article 6(1)(i) PLT.

However, it was noted in the Working Group on Reform of the PCT that some of the proposed amendments raised difficulties of possible inconsistency, to varying degrees, with the PCT Articles, in particular, in providing for the according of a filing date where no claims were present in an international application..$^{50-51}$

\subsection{Filing date requirements - PCT vs. PLT}

The differences between the filing date requirements under the PCT as compared to the PLT cause friction. If a State becomes a Contracting Party to the PLT, this State is obliged to accord a filing date to an application which complies with the requirements applicable under Article 5 PLT. ${ }^{52}$ No re-dating of the application will be effected if the applicant supplies a set of claims within some time after the filing date, either of his own volition or upon invitation by the Office where the application was filed [cf. Rule 2 PLT]. Where an application as filed does not contain one or more claims, which may be required under Article 6(1)(i) PLT [with reference to PCT Article 3(2)], a PLT Contracting Party may require that at least one claim be subsequently filed under Article 6(7) PLT, within the time limit prescribed in Rule 6(1) PLT. However, failure to file such claim(s)

49 "Changes related to the Patent Law Treaty (PLT): Absence of 'Formal' Claims" (prepared by the International Bureau), Working Group on Reform of the PCT, Document PCT/R/WG/2/8 (March 2002), Items 3-4.

50 "Summary of the session" - "Changes Related to the PLT" (prepared by the Chair), Document PCT/R/WG/1/9 (November 2002), Item 21(iii).

${ }^{1}$ "Summary of the session" - "Other Matters" (prepared by the Chair), Document $\mathrm{PCT/R/WG/2/12,} \mathrm{Item} 59$.

See http://www.wipo.int/meetings/en/details.jsp?meeting_id=4554.

52 "Explanatory Notes on the Patent Law Treaty and Regulations under the Patent Law Treaty adopted by the Diplomatic Conference on June 1, 2000", Document PT/DC/48 Prov. (November 2000), Note 5.01. 
within the prescribed time limit would not result in the retroactive loss of the filing date, even if the application were refused under Article 6(8)(a) PLT. ${ }^{53}$

Suppose an applicant files an international application with the intention of, at a later date, entering the national phase before the national Office of that State. If his application, on filing, does not contain a least one claim, no international filing date will be accorded by the receiving Office acting under the PCT [PCT Article 11(1)(iii)(e)]. The receiving Office (which may be the national Office of the PLT Contracting Party) will invite the applicant to file at least one claim [PCT Article 11(2)(a) and Rule 20.3(a)]. If the applicant complies with the invitation, the receiving Office accords as the international filing date, the date of receipt of the required correction [PCT Article 11(2)(b) and Rule 20.3(b)]. The question arises: will the national Office of the PLT Contracting Party, after entry of the international application into its national phase, accept the initial filing date (when claims were not included) or the international filing date (when claims were received by the receiving Office)? The answer is that only the international filing date can be accepted as the filing date under the national law of the State.

If, under the provisions of the PCT, the applicant upon invitation by the receiving Office or of his own volition does not file at least one claim, his international application will not be refused. Instead, the receiving Office will promptly notify the applicant that the application is not and will not be treated as an international application [PCT Rule 20.4(i)]. ${ }^{54}$ As no international filing date will be accorded to the application, this also implies that the international application will not have the effect of a regular national application [PCT Article 11(3)] and that no priority can be claimed from it [PCT Article 11(4)].

\subsection{Filing by reference to a previously filed application - Article 5(7) PLT}

As described hereinabove, Article 5(7) PLT obliges a Contracting Party to accept, at the time of filing, the replacement of the description and any drawings in an application by a reference to a previously filed application, ${ }^{55}$ subject to certain formal requirements.

Rule 2(5) PLT provides two different types of requirements: ${ }^{56}$ obligatory requirements (indicated by "shall"), and optional requirements (indicated by "may require"). Each PLT

53 Ibid., Note 5.01

54 However, not all is lost in such a case. Pursuant PCT Article 26 the applicant would stand a good chance of proceeding with this application as a "national" application with the original filing date if the national Office does not require a claim as a filing date requirement under its national law.

55 Note that a "previously filed application" need not be an application from which priority is claimed. Hence, the previously filed application may have been filed more than 12 months prior to the filing date of the international application.

${ }_{56}$ "Explanatory Notes on the Patent Law Treaty and Regulations under the Patent Law Treaty adopted by the Diplomatic Conference on June 1, 2000", Document PT/DC/48 Prov. (November 2000), Note R 2.05. 
Contracting Party can decide which optional requirements it incorporates into its law as compulsory requirements for the accordance of a filing date. Article 5(7)(b) PLT permits a Contracting Party to regard an application as not having been filed if the applicant fails to comply with the obligatory and any optional requirements under Rule 2(5) PLT implemented as compulsory by a PLT Contracting Party. ${ }^{57}$

Rule 2(5)(a) PLT prescribes that the indication that the description and any drawings are replaced by the reference to the previously filed application, as well as the number of that application and the Office with which that application was filed, must be included in the application. According to Rule 2(5)(a) PLT, a PLT Contracting Party may require that the reference also indicates the filing date of the previously filed application. Rule 2(5)(a) PLT does not require that the reference identifies any claims of the previously filed application that are incorporated by reference, since claims are not required for the purposes of the filing date. ${ }^{58}$ In addition, a PLT Contracting Party may decide which of the optional requirements mentioned in Rule 2(5)(b) PLT are made compulsory for the accordance of a filing date:

(i) Filing a copy of the previously filed application and, where the previously filed application is not in a language accepted by the Office, a translation of that previously filed application, be filed with the Office within a time limit which shall be not less than two months from the date of receipt of the application;

(ii) Filing a certified copy of the previously filed application with the Office within a time limit which shall be not less than four months from the date of the receipt of the application.

Where the applicant indicated in the application containing the reference is not the same as the applicant identified in the previously filed application, the Office pursuant Rule 2(5)(c) PLT may require a declaration or other evidence that the previously filed application had been filed by that applicant's predecessor or successor in title. ${ }^{59}$ The latter requirement is not often implemented in the patent law of PLT Contracting Parties. $^{60}$

\subsection{Filing by reference to a previously filed application - PCT}

With respect to "filing by reference", the PCT was not aligned to the PLT. There was an initial proposal to incorporate a new Rule $20.4(\mathrm{e})$ into the $\mathrm{PCT}$, which would provide for a

\footnotetext{
Ibid.; interpretation of Note 5.24 .

Ibid., Note R 2.05.

Ibid., Note R 2.05 .

60 The EPO has not implemented this requirement in Rule 56 EPC 2000.

In Great-Britain, the Patent Act 1997 (as amended) includes a provision in Article 15(1)(c)(ii) stating that a reference to an earlier relevant application must be "made by the applicant or a predecessor in title of his."
} 
reference to another document to replace the description, drawings and claims. ${ }^{61}$ The formulation included: $:^{62}$

For the purposes of Article 11(1)(iii)(d), a reference, made upon filing of the international application, in a language accepted by the receiving Office under Rule 12.1(a), to a previously filed application shall ... replace the description and any drawings and, if applicable, the claim or claims.

Later on, the matter of "filing by reference" in the sense of the PLT was not pursued due to time constraints and low priority. ${ }^{63}$ As a consequence, in the Request Form [PCT/RO/101] no provision has been included to file an international application while referring to a previously filed application. This means that an applicant upon filing an international application always must file documents comprising the description, any drawings and, also, at least one claim.

Filing by reference is advantageous when transmitting the application by fax, since the application documents need not be sent anymore. However, when using electronic filing, the effort to include a copy of the application is relatively small. Hence, the advance in technology away from fax transmission appears to have taken away the main advantage of filing by reference. Moreover, filing the complete application does not have the disadvantages of the risk of uncorrectable errors and the obligation to provide a (certified) copy of the previously filed application.

Filing an application by reference to a previously filed application is, in particular, convenient for applicants in that upon filing the application only the earlier application need be correctly identified in the Request Form. As more and more patent applications become available in electronic manner, the applicant need no longer file the corresponding application documents. "Filing by reference" is most convenient when filing a divisional application: it suffices to refer to the description and drawings of the parent application while, preferably at the same time, filing a new set of claims. At present, the PCT does not provide for the filing of divisional applications during the international phase. ${ }^{64-65}$

61 "Changes related to the Patent Law Treaty (PLT): Contents of the International Application; Language of the International Application and Translations; Right of Priority and Priority Claims; Time Limits" (prepared by the International Bureau), Working Group on Reform of the PCT, Document PCT/R/WG/2/8, Item 5 .

62 Ibid., Annex I.

63 "Changes related to the Patent Law Treaty (PLT) - Conform PCT "Missing Part" requirements to those of the PLT" (prepared by the International Bureau), Working Group on Reform of the $P C T$, Document PCT/R/WG/4/2 (March 2003), Item 5. See http://www.wipo.int/meetings/en/details.jsp?meeting_id=4554.

64 See, e.g., "Divisional applications under the PCT" (prepared by the International Bureau), Working Group on Reform of the PCT, Document PCT/R/WG/4/9 (April 2003). See http://www.wipo.int/meetings/en/details.jsp?meeting_id=4554. 
In $\ 7$ it will be shown in that "filing by reference" under the PCT is possible, however, in a restrictive manner. In $\$ 6.6$ a different use of "filing by reference" will be described allowing under the PCT to file so-called missing elements, i.e. where the entire description or all the claims are missing.

\section{Further inconsistencies in provisions dealing with defects which may affect the filing date}

\subsection{Filing missing parts of the description or missing drawings - Article 5(6) PLT}

Article 5(6) PLT obliges a PLT Contracting Party to allow the inclusion, in the application, of a missing part of the description or a missing drawing filed within a prescribed time limit. ${ }^{66}$ The provision applies whether or not the applicant has been notified of an item being missing. Normally, the late filing of a missing part of the description or a missing drawing causes the filing date to become the date of receipt of the missing item, provided that all of the other requirements for the accordance of a filing date have been complied with on that date [cf. Rule 2(3) PLT].

In particular, Article 5(6)(b) PLT obliges a Contracting Party to allow, upon the request of the applicant, the inclusion of a missing part of the description or a missing drawing in the application without loss of the initial filing date, where that missing part or missing drawing is "completely contained" in an earlier application from which priority is claimed, provided the additional formality requirements are complied with [cf. Rule 2(3) and (4) $\mathrm{PLT}] .{ }^{67}$ The PLT leaves the question whether, in a particular case, a missing part of the description or a missing drawing is "completely contained" in the earlier application to be treated as a clerical check by the Office, based on the indications provided by the applicant. $^{68}$

The wording of Article 5(6)(b) PLT is very specific with respect to the nature of the earlier application and by when that application must be mentioned [italics added]:

65 Ibid., Items 5-6: While, at present, the PCT does not provide for the filing, during the international phase, of divisional applications, it is to be noted that the $1968 \mathrm{draft}$ of the PCT contained provisions in both the draft Treaty and the draft Regulations under the Treaty which would have allowed the applicant, in the case of lack of unity of invention, at his option, to either (i) restrict the claims, or (ii) to pay additional fees, or divide the application, or both. However, in the 1969 draft of the PCT those provisions were deleted, and the final text of the PCT as signed at the Washington Diplomatic Conference in June 1970 does not contain any provisions concerning the division of an international application during the international phase.

66 "Explanatory Notes on the Patent Law Treaty and Regulations under the Patent Law Treaty adopted by the Diplomatic Conference on June 1, 2000", Document PT/DC/48 Prov. (November 2000), Note R 5.21.

${ }_{67}$ Ibid., Note 5.21.

68 Ibid., Note R 2.04. 
Where the missing part of the description or the missing drawing is filed under subparagraph (a) to rectify its omission from an application which, at the date on which one or more elements referred to in paragraph (1)(a) were first received by the Office, claims the priority of an earlier application, the filing date shall ... be the date on which all the requirements applied by the Contracting Party under paragraphs (1) and (2) are complied with.

The italicized part of the above citation makes it clear that when the applicant desires to make use of the provision of Article 5(6)(b) PLT to incorporate a missing part of the description or a missing drawing into an already filed application without loss of the filing date initially accorded by the Office, the earlier application must not only be a priority application but also that the priority of this earlier application must have been claimed on "the date on which one or more elements" referred to in Article 5(1)(a) PLT "were first received by the Office", i.e. on the initial filing date.

\subsection{Filing missing parts of the description or missing drawings - PCT Rule 20.5}

The requirements as set out in the Article 5(6) PLT for filing missing parts of the description or missing drawings have been taken over in PCT Rule 20. In particular, "missing parts" are defined in PCT Rule 20.5 [italics added]:

Where, in determining whether the papers purporting to be an international application fulfill the requirements of Article 11(1), the receiving Office finds that a part of the description, claims or drawings is or appears to be missing, including the case where all of the drawings are or appear to be missing but not including the case where an entire element referred to in Article 11(1)(iii)(d) or (e) is or appears to be missing ...

According to the above definition a "missing part" includes any part of the description, any part of the claims and/or any part or all of the drawings of the international application as long as it is not the "entire" description [PCT Article 11(1)(iii)(d)] or the "entire" set of claims [PCT Article 11(1)(iii)(e)]. As can be seen, the definition also refers to a missing part of the claims (see $\$ 6.4$ ).

Most patent laws already had a provision allowing the applicant to late file missing drawings. In the PCT this is dealt with in PCT Article 14(2):

If the international application refers to drawings which, in fact, are not included in that application, the receiving Office shall notify the applicant accordingly and he may furnish them within the prescribed time limit and, if he does, the international filing date shall be the date on which the drawings are received by the receiving Office. Otherwise, any reference to the said drawings shall be considered nonexistent. 
Before the Reform of the PCT in view of the PLT (April 2007), PCT Article 14(2) found its implementation in PCT Rule 26.6. Although PCT Article 14(2) and Rule 26 belong to the "formalities examination" by the receiving Office, the consequence of the late furnishing of drawings was (always) that the international filing date, already accorded pursuant PCT Article 11(1), was re-dated to the date on which the missing drawings were received by the receiving Office.

As a result of aligning the PCT with the PLT, the requirement of the late filing of drawings was incorporated into PCT Rule 20 implementing PCT Article 11 ("international filing date") while abolishing PCT Rule 26.6. ${ }^{69}$ At the same time, the scope of PCT Rule 20 was broadened, allowing the applicant to file not only missing drawings but also missing parts of the description and/or missing parts of the claims (see $\$ 6.4$ ), as well as providing for the case when the entire description and/or all the claims are missing (see \$6.6).

Missing parts of the description or missing drawings can be filed by the applicant upon invitation when the receiving Office finds that parts of the description and/or drawings are, or appear to be, missing. PCT Rule 20.5(a) deals with the case that the receiving Office finds that a "missing part" is missing or appears to be missing. The time limit for furnishing such missing parts is two months from the date of the invitation [PCT Rule 20.7(a)(i)].

The filing of "missing parts" can also be done by the applicant of his own volition. This own volition is hidden in the wording "or otherwise" in PCT Rule 20.5(b), in the sentence [italics added]:

"Where, following an invitation under paragraph (a) or otherwise, the applicant furnishes to the receiving Office ..."

If the applicant notices and wishes to correct the defect on his own initiative, this is permitted within a time limit of two months from the date on which papers were first received by the receiving Office [PCT Rule 20.7(a)(ii)]. The time limits in PCT Rule 20.7(a)(i) and (ii) were fixed at two months in alignment with the minimum duration of such time limits under the Patent Law Treaty. ${ }^{70}$

\subsubsection{Filing missing parts - Re-dating the international application}

The filing of missing parts of the description or missing drawings normally results in a re-dating of the international filing date. If the applicant furnishes to the receiving Office the required correction under PCT Article 11(2) on a date after the date of receipt of the

69 The abolishment of PCT Rule 26.6 has diminished the effectiveness of PCT Article 14(2) because all issues relating to late-filed drawings are now covered in PCT Rule 20 implementing PCT Article 11(2).

70 "Report" - "Missing Elements and Parts of the International Application" (adopted by the Working Group), Document PCT/R/WG/7/13 (May 2005), Item 24.

See http://www.wipo.int/meetings/en/details.jsp?meeting id=7129. 
purported international application (but falling within the applicable time limit under PCT Rule 20.7), the receiving Office will accord that later date as the international filing date [cf. PCT Rule 20.3(b)(i) and Rule 20.5(c)].

Where the international filing date has been corrected in the above sense, the applicant may realize that his re-dated international application no longer lies within the period for claiming priority from an earlier (national) application and he might want to undo the filing of the missing parts retroactively. In that case, the applicant may request the receiving Office to disregard the missing part in order to establish that the initial filing date ${ }^{71}$ becomes the international filing date and, hence, to retain the priority claim [PCT Rule 20.5(e)]. This notice of withdrawal has to be sent to the receiving Office within one month from the date of mailing of the later submitted parts [PCT Rule 20.5(e)].

Generally, the "priority period" is twelve months from the filing date of the earlier application from which priority is claimed..$^{72}$ If the corrected international filing date falls outside this 12-month period but within a period of two months after the expiration of the priority period of the priority claim concerned, the applicant may file a request for restoration of right of priority at the receiving Office under the applicable condition [PCT Rule 26bis.3]. ${ }^{73}$

\subsubsection{Filing missing parts without re-dating - Incorporation by reference}

Under certain circumstances, missing parts of the description or missing drawings can be added to an international application without affecting the international filing date. In line with Article 5(6) and Rule 2(4) PLT, this is possible when the missing parts of the description or the missing drawings are "completely contained" in an earlier application from which priority is claimed on the initial filing date.

As a first step the applicant must declare, upon filing the international application containing at least some of the elements referred to in PCT Article 11(1)(iii) and while claiming priority from an earlier application, that he reserves the right to later on rely on parts or elements which are completely contained in the priority application. To this end Box No. VI "Priority Claim" of the Request Form (PCT/RO/101) includes a pre-printed statement, stating:

${ }^{71}$ In this Chapter the wording the "initial filing date" is used to indicate the date on which one or more elements referred to in PCT Article 11(1)(iii) were first received by the receiving Office.

${ }^{2}$ Cf. PCT Article 8(2) referring to Article 4 of the Paris Convention. Article $4 \mathrm{~A}(1)$ and $4 \mathrm{C}(1)$ of the Paris Convention regulate a right of priority of 12 months for patents and utility models.

73 A number of receiving Offices has declared that PCT Rule 26 bis. 3 is not compatible with the national law applied by the receiving Office [PCT Rule 26bis.3(j)]. For these Offices, restoration of the right of priority is not possible. In addition, a number of designated/elected Offices has declared that restoration of the right of priority is not compatible with the national law as applied by the designated/elected Office [PCT Rule 49ter.1(g)]. 
Incorporation by reference: where an element of the international application referred to in Article 11(1)(iii)(d) or (e) or a part of the description, claims or drawings referred to in Rule 20.5(a) is not otherwise contained in this international application but is completely contained in an earlier application whose priority is claimed on the date on which one or more elements referred to in Article 11(1)(iii) were first received by the receiving Office, that element or part is, subject to confirmation under Rule 20.6, incorporated by reference in this international application for the purposes of Rule 20.6. ${ }^{74}$

The formulation of this statement is based on PCT Rule 4.18 and is formulated in line with Article 5(6)(b) and Rule 2(4)(5) PLT. The priority claim must have been included in the request on the initial filing date and cannot be added later on, e.g., by applying PCT Rule 26bis.1(a). ${ }^{75}$ The latter requirement is in line with Article 5(6) PLT.

If the applicant files a missing part of the description or a missing drawing based on the content of the application from which priority is claimed on the initial filing date, the following requirements must be met [cf. PCT Rule 20.6(a)]:

- The applicant must confirm the incorporation by reference by way of a written notice to the receiving Office.

- Such notice should be accompanied by:

(i) a sheet or sheets embodying the missing part as contained in the application from which priority is claimed;

(ii) where the applicant has not already complied with the requirements of PCT Rule 17.1(a), (b) or (b-bis), ${ }^{76}$ a copy of the priority application as filed;

(iii) where the priority application is not in a language in which the international application is filed [PCT Rule 20.6(a)(iii)], a translation or translations of the priority application; and

(iv) an indication as to where the missing part is contained in the priority application and, where applicable, in any translation of the earlier application.

74 If such a statement was not contained in the request at the time of filing, it can only be added to the request if it was otherwise contained in, or submitted with, the international application on the date of filing [cf. PCT Rule 4.18, last sentence].

75 PCT Applicant's Guide - International Phase, item 6.028.

See http://www.wipo.int/pct/guide/en/gdvolı/pdf/gdvol1.pdf.

76 PCT Rule 17.1(a) relates to the case where a certified copy of the earlier application has been submitted by the applicant to the International Bureau or the receiving Office (unless it has already been filed with the receiving Office together with the international application). PCT Rule 17.1(b) relates to the case where the priority document is issued by the receiving Office and the applicant has requested the receiving Office to transmit the priority document to the International Bureau.

PCT Rule 17.1(b-bis) relates to the case where the priority document is available to either the International Bureau or to the receiving Office from a digital library and the applicant has requested to obtain the priority document from such a digital library. 
It seems superfluous that upon filing missing parts of the description or missing drawings, the applicant should confirm the incorporation by reference statement under PCT Rule 4.18. The relevance of the formal confirmation of the "incorporation by reference" was extensively discussed in the Working Group on Reform of the PCT. ${ }^{77-78}$

The start of the 2-month time limit for confirming the incorporation by reference of missing parts of the description or missing drawings differs depending on the situation. Where no invitation by the receiving Office has been sent to submit missing parts, the time limit to confirm is two months from the date on which papers were first received by the receiving Office [PCT Rule 20.7(a)(ii)]. Where such an invitation has been issued, the time limit to confirm is two months from the date of mailing of this invitation [PCT Rule $20.7(\mathrm{a})(\mathrm{i})]^{79}$

Where the receiving Office finds that the requirements of PCT Rule 4.18 and PCT Rule 20.6(a) have been complied with and that the missing part of the description or the missing drawing is completely contained in the priority application, that part is considered to have been contained in the purported international application on the initial filing date.

The procedure of incorporation by reference does not apply if the receiving Office has notified the International Bureau under PCT Rule 20.8(a) that any of Rules 20.3(a)(ii) and 20.3(b)(ii), 20.5(a)(ii) and 20.5(a)(d), and 20.6 are not compatible with its national law. ${ }^{80}$

In most Contracting States, the parts will be treated as if they were actually contained in the international application as originally filed. ${ }^{81}$ However, those designated/elected Offices which have submitted notifications of incompatibility under PCT Rule 20.8(b), may treat the international application as if the international filing date had been

77 "Summary of the Session" - "'Missing Part' Requirements" (prepared by the International Bureau), Working Group on Reform of the PCT, Document PCT/R/WG/5/13 (November 2003), Item 88.

See http://www.wipo.int/meetings/en/details.jsp?meeting_id=4554.

78 The outcome of the discussion in the Working Group on Reform of the PCT was that "incorporation by reference" is not to be regarded as a standard feature applicable to all international applications but that express confirmation by the applicant would be required if he wanted to rely on this instrument to correct a mistake made when filing the application. In other words, the content of prior applications is not automatically incorporated by reference into the international application; rather an express confirmation is required by the applicant in each and every case.

79 If this time limit expires after the expiration of 12 months from the filing date of the earliest application, the priority of which is claimed, the receiving Office will draw this circumstance to the attention of the applicant [PCT Applicant's Guide - International phase, Item 6.029]. See http://www.wipo.int/pct/en/appguide/index.jsp.

8o Such a receiving Office will neither invite nor accept a confirmation of the incorporation by reference.

${ }^{81}$ Designated and elected Offices may, to a limited extent, review decisions by receiving Offices which have allowed incorporation by reference [PCT Rule 82ter.1(b)]. 
accorded on the basis of the date on which the sheets containing the missing parts were submitted [PCT Rule 20.8(c)]. ${ }^{82}$

\subsection{Missing part of the claims - Article 5(6) PLT}

Article 5(6) PLT does not address the issue of allowing the inclusion, in the application, of a missing part of the claims filed within a prescribed time limit. The reason for this is, that claims are not a filing date requirement according to the PLT.

\subsection{Missing part of the claims - PCT Rule 20.5}

As discussed, PCT Article 11(1)(iii)(e) requires the presence of "a part which on the face of it appears to be a claim or claims". Hence, the case may arise that a part of the claims is missing. It is for this reason that the PCT allows the filing of a missing part of the claims. The definition in PCT Rule 20.5 ("missing parts") includes the situation where a part of the claims are missing [italics added]:

Where, in determining whether the papers purporting to be an international application fulfill the requirements of Article 11(1), the receiving Office finds that a part of the description, claims or drawings is or appears to be missing, including the case where all of the drawings are or appear to be missing but not including the case where an entire element referred to in Article 11(1)(iii)(d) or (e) is or appears to be missing ...

According to the above definition a "missing part" includes any part of the description, any part of the claims and/or any part or all of the drawings of the international application as long as it is not the "entire" description or the "entire" set of claims (see \6.6).

Analogous as to what is described in $\$ 6.2$, a missing part of the claims can be filed by the applicant of his own volition or upon invitation, when the receiving Office finds that a part of the claims is, or appears to be, missing. The filing of a missing part of the claims normally results in a re-dating of the international filing date [cf. PCT Rule 20.5(c)].

Analogous as to what is described in $\$ 6.2$, a missing part of the claims can be added to an international application without affecting the international filing date. This is possible when the missing part of the claims is "completely contained" in an earlier application from which priority is claimed on the initial filing date.

82 Missing parts may be omitted only after having given the applicant the opportunity to make observations on this outcome and/or to request that, at least, the missing parts which had been furnished be disregarded [PCT Rule 20.8(C)]. 


\subsection{Missing entire description of missing entire set of claims - Article 5(6) PLT}

Article 5(6) PLT deals with the inclusion, in the application, of missing parts of the description and missing drawings. However, Article 5(6) PLT does not address the issue of allowing the inclusion of the entire description and/or the entire set of claims.

\subsection{Missing entire description of missing entire set of claims - PCT Rule 20.6}

For the purpose of according an international filing date, PCT Article 11(1)(iii)(d) and (e), as discussed, require the presence of "a part which on the face of it appears to be a description" and "a part which on the face of it appears to be a claim or claims", respectively. In addition, the PCT did not implement the provision of "filing by reference" [see $\ 5.6]$.

The Working Group on Reform of the PCT considered a different approach with respect to the issue of "filing by reference" by considering that under the PLT, an applicant can, for the purposes of the filing date of the application, replace the description and any drawings by a reference to a previously filed application [see Article 5(7) and Rule 2(5) PLT]. In particular, the Working Group explored the possibilities as to whether the proposed incorporation by reference discussed in the context of "missing parts" could be extended to cover the contents of such earlier application for the purposes of overcoming PCT Article 11(1)(iii)(d) and (e) defects; such defects are addressed as "missing elements" and refer, e.g., to the case where the entire description or all the claims is missing. ${ }^{83}$

The result was that the PCT Regulations were amended by adopting a new Rule 20.6 allowing the applicant, by way of reference to an earlier application, not only to rectify the omission, at the time of filing, of certain parts of the international application [the so-called "incorporation by reference" of "missing parts", similar to the provision under Article 5(6)(b) and Rule 2(4) PLT] without loss of the international filing date, but also to allow replacement of the "part which on the face of it appears to be a description" [PCT Article 11(1)(iii)(d)] and/or the "part which on the face of it appears to be a claim or claims" [PCT Article 11(1)(iii)(e)] for the purposes of the international filing date [the so-called incorporation by reference of "missing elements," similar to the provision under Article 5(7) PLT in respect of the description and any drawings]. ${ }^{84}$

From the definition in PCT Rule 20.5 ("missing parts") it follows that a "missing part" only includes any part of the description, any part of the claims and/or any part or all of the drawings of the international application. The wording "missing elements" is used when the "entire" description or the "entire" set of claims is or appears to be missing. Such an "element" is mentioned in PCT Rule 20.3(a)(ii) and in 20.3(b)(ii) where it is identified as:

83 "'Missing part' Requirements" (prepared by the International Bureau), Working Group on Reform of the PCT, Document PCT/R/WG/6/4 (March 2004), Item 11. See http://www.wipo.int/meetings/en/details.jsp?meeting_id=4554. Ibid., Item 12. 
"an element referred to in Article 11(1)(iii)(d) or (e)". This should not be confused with the wording: "one or more elements referred to in Article 11(1)(iii)" which is used in PCT Rule 20.3(b)(ii), 20.5(d), 20.6(b) and 20.7(a)(ii), because the latter definition includes all five items of PCT Article 11(1)(iii) including the description (item d) and the claims (item e). To further confuse things, in PCT Rule 20.5(a) and 20.6(a)(i) reference is made to [italics added]: "an entire element referred to in Article 11(1)(iii)(d) or (e)" which wording probably means the same as "element" at the other occurrences. ${ }^{85}$ Apparently, the word "entire" has been added to emphasize the difference between a "part" of the description or claims and the "entire" description or claims. For legal consistency, it would, however, be better to delete "entire" from the wording "entire element" in PCT Rule 20.5(a) and 20.6(a)(i).

"Missing elements" can be filed by the applicant of his own volition or upon invitation when the receiving Office finds that the entire description and/or the entire set of claims are, or appear to be, missing. Such a finding is addressed as a "defect under PCT Article 11(1)" and dealt with in PCT Rule 20.3 in relation to any of the requirements of PCT Article 11(1)(iii)(a)-(e) and, in particular, with respect to "an element referred to in Article 11(1)(iii)(d) or (e)", i.e. when the entire description and/or the entire set of claims are missing.

If the applicant files a "missing element" based on the content of the application from which priority is claimed on the initial filing date, the following requirements must be met [cf. PCT Rule 20.6(a)]:

- The applicant must confirm the incorporation by reference by way of a written notice to the receiving Office.

- Such notice should be accompanied by:

(i) a sheet or sheets embodying the missing element as contained in the application from which priority is claimed;

(ii) where the applicant has not already complied with the requirements of PCT Rule 17.1(a), (b) or (b-bis), a copy of the priority application as filed;

(iii) where the priority application is not in a language in which the international application is filed [PCT Rule 20.6(a)(iii)], a translation or translations of the priority application.

Similar to the situation of "missing parts", the start of the 2-month time limit for confirming the incorporation by reference of missing elements differs depending on whether the receiving Office has sent an invitation to submit missing element or whether the applicant files missing elements of his own volition. Where the receiving Office finds that the requirements of PCT Rule 4.18 and PCT Rule 20.6(a) have been complied with

${ }^{85}$ Note that the wording "entire elements" is also used in PCT Rule 91.1(g)(i) in relation to PCT Article 3(2). 
and that the missing element is completely contained in the priority application, that element is considered to have been contained in the purported international application on the initial filing date.

In most Contracting States, the elements will be treated as if they were actually contained in the international application as originally filed. ${ }^{86}$ However, those designated/elected Offices which have submitted notifications of incompatibility under PCT Rule 20.8(b), may treat the international application as if the international filing date had been accorded on the basis of the date on which the sheets containing the missing elements were submitted [PCT Rule 20.8(c)].

\section{Filing an international application by reference to a previously filed application}

In $\ 5.6$ it was discussed that the PCT was not aligned to the PLT with respect to the issue of "filing by reference". Although not explicitly provided for in the PCT, there is, however, a possibility to file an international application by reference to an earlier application, if that earlier application is an application from which priority is claimed on the initial filing date. Suppose that on that day the applicant only files a filled-in Request Form $[P C T / R O / 101]$ containing at least the priority claim to be relied on for the incorporation of reference. By filing the Request Form to the receiving Office, the receiving Office has at least received "an indication that" the application "is intended as an international application", thereby meeting the requirement of PCT Article 11(1)(iii)(a). In addition, the receiving Office will notice that the application as filed does not fulfill all requirements of PCT Article 11(1)(iii) for the accordance of an international filing date and will promptly invite the applicant to file the required corrections [PCT Article 11(2) and Rule 20.3(a)]. The applicant can then confirm that the missing elements (the entire description and the entire set of claims) and the missing part (all of the drawings) are incorporated by reference based on the priority application [PCT Rule 20.6 and 4.18]. Of course, upon incorporating by reference the missing elements and the missing parts, the applicant must submit to the receiving Office all the sheets embodying the missing elements and the missing parts [PCT Rule 20.6(a)(i)]. If not already available to the receiving Office, the applicant must also file a copy (and possibly a translation) of the priority application [PCT Rule 20.6(a)(ii) and (iii)].

86 Designated and elected Offices may, to a limited extent, review decisions by receiving Offices which have allowed incorporation by reference [PCT Rule 82ter.1(b)]. 


\section{Discussion}

\subsection{Amendment of the PCT Articles and the Regulations}

The PCT Articles can be revised by a Revision Conference of the PCT Contraction States [PCT Article 60(1)]. With currently more than 140 PCT Contracting States, it will be difficult to achieve consensus about the required revision of the PCT Articles.

The "Regulations under the PCT" may be amended by the Assembly [PCT Article 58(3)] and require unanimous consent. In order to make certain amendments acceptable, transitional reservations are frequently incorporated in the amended Regulations. A PCT Contracting State declaring that such an amendment is not compatible with the national law of the State need not apply the amended provision until such time as the position might be solved under its national law. ${ }^{87}$

\section{2 "Bending" of PCT Articles in the Regulations}

Flexibility to the system has over the years been added to the PCT by amending the Regulations under the PCT. In this manner, the rigidity of certain PCT Articles has been mitigated in the PCT Regulations. On a number of occasions this has led to inconsistencies between the PCT Articles and the PCT Regulations. Some examples of such inconsistencies are given in the following paragraphs.

\subsubsection{Designation fees}

A first example of an inconsistency between a PCT Article and the PCT Regulations is that it was desired at a certain moment in time to abolish the designation fees and incorporate these into a new so-called "international filing fee". ${ }^{88}$

PCT Article 4(2) states [italics added]:

"Every designation shall be subject to the payment of the prescribed fee within the prescribed time limit."

The word "prescribed" indicates that the "fee" and the "time limit" are to be found somewhere in the PCT Regulations. Before the abolishment of the designation fee, it was "prescribed" in PCT Rule 15.2 that the "international fee" consists of two parts: the "basic fee" and the "designation fee". The time limit for payment of the designation fee was prescribed in PCT Rule 15.4. After the accordance of the international filing date, the receiving Office checks, amongst others, whether the fees have been paid [PCT

87 For examples of reservations and incompatibilities [situation October 2011] see PCT Rule 4.9(b), Rule 4.10(d), Rule 20.1(d), Rule 20.8(a) and (b), Rule 26.3ter(b) and (d), Rule 26bis.3(j), Rule 49.5(l), Rule 49.6(f), Rule 49ter.1(g), Rule 49ter.2(h), Rule 51bis.1(f), Rule 51bis.2(c), Rule 51bis.3(c) and Rule 66.1bis(b).

88 "The Concept and Operation of the Designation System" (prepared by the International Bureau), Working Group on Reform of the PCT, Document PCT/R/WG/1/1 (September 2001), Item 59. See http://www.wipo.int/meetings/en/details.jsp?meeting_id=4554. 
Article 14]. In PCT Article 14(3)(a) the receiving Office checks whether within the prescribed time limit "no fee prescribed under Article 4(2) has been paid in respect of any of the designated States". In PCT Article 14(3)(b) the receiving Office checks whether "the fee prescribed under Article 4(2) has been paid in respect of one or more (but less than all) designated States within the prescribed time limit". The various consequences of non-compliance are indicated in the respective paragraphs of the Articles.

What happened when the payment of designation fees was abolished? ${ }^{89}$ Well, there is no longer any "prescribed" fee and there is no longer any "prescribed" time limit for the designation fee(s) in the PCT Regulations. ${ }^{90}$ The two instances of the word "prescribed" in PCT Article 4(2) are preserved without reference in the Regulations. No sentence was added somewhere in amended PCT Rule 15 about the international filing fee, such as:

"By paying the international filing fee within the time limit of Rule 15.4, the applicant is deemed to have paid the fee prescribed in Article 4(2) within the time limit prescribed in Article 4(2)".91

It can be concluded that PCT Article 4(2) has become a "lame duck".

What happened with the references in PCT Article 14(3) with respect to the "fee prescribed under Article $4(2)^{\prime \prime}$ ? As the designation fee was linked to the international filing fee, the wording "fee prescribed under Article 4(2)" was given the following interpretation in PCT Rule 27.1(b):

"For the purposes of Article 14(3)(a) and (b), "the fee prescribed under Article 4(2)" means the international filing fee (Rule 15.1) and, where required, the late payment fee (Rule 16bis.2)."

Another consequence of the abolishment of the designation fees was the introduction of PCT Rule 4.9 specifying an automatic and all-inclusive designation of all PCT Contracting States, for all types of protection and also in respect of regional patent treaties. The introduction of this Rule has more or less inactivated PCT Articles 43, 44 and 45, at least insofar as the international phase is concerned.

\subsubsection{WTO priority claims}

A second example of an inconsistency between the PCT Articles and Rules is that it was desired, in view of the TRIPs Agreement, to acknowledge apart from priority claims from Paris Convention States also priority claims from Parties to the WTO. However, PCT Article 8(1) is "rigid" about this:

89 The Regulations under the PCT as amended effective 1 January 2004.

90 There is no reference in the "PCT Applicant's Guide - International Phase" to PCT Article 4(2). In addition, there is no mention of the "designation fee".

${ }_{91}$ The original proposal of the International Bureau for the reformulation of PCT Rule 15.1, as contained in the Annex of PCT/R/WG/1/1, in relation to the "international filing fee" contained a sentence: "That fee includes the fee referred to in Article 4(2)." However, this sentence was abolished in later versions of PCT Rule 15.1. 
"The international application may contain a declaration, as prescribed in the PCT Regulations, claiming the priority of one or more earlier applications filed in or for any country party to the Paris Convention for the Protection of Industrial Property."

In addition PCT Article 8(2)(a) specifically refers to the "Stockholm Act of the Paris Convention". Flexibility was added to the Regulations, by the following addition in PCT Rule 4.10(a) [italics added]:

Any declaration referred to in Article 8(1) ("priority claim") may claim the priority of one or more earlier applications filed either in or for any country party to the Paris Convention for the Protection of Industrial Property or in or for any Member of the World Trade Organization that is not party to that Convention.

\subsubsection{Misalignments in the Regulations}

There are also minor "misalignments" between various Rules in the Regulations under the PCT. For example, PCT Rule 4.5 clearly states, without any prejudice, that the indications of the applicants in the request with respect to name, address, nationality and residence must be indicated for "each of them". Similarly, PCT Rule 4.15 clearly states, without any prejudice, that all applicants must sign the request. When looking at these Rules, one is made to believe that "all" applicants have to comply with the prescriptions in these Rules. Nevertheless, PCT Rule 26.2bis(b) and (a), respectively, say that [for the purpose of the formalities check by the receiving Office under Article 14(1)(a)] it is sufficient if one of the applicants meets the requirement of PCT Rule 4.5(a)(ii) and (iii), and Rule 4.15, respectively. ${ }^{92}$

Such inconsistencies render the PCT user-unfriendly.

\subsection{Discussions in the Working Group on Reform of the PCT}

At the first session of the Working Group on Reform of the PCT held in 2001, proposals were discussed to amend the Regulations under the PCT so as to align the requirements of the PCT with regard to claims as a filing date requirement to those of the PLT. ${ }^{93}$ PCT Article 11(1)(iii)(e) requires that for an international filing date to be accorded, an international application shall, inter alia, contain a part which on the face of it appears to be a claim or claims whereas, under the PLT, claims are not required for a filing date to

92 Note, however, that any designated Office may in accordance with the applicable national law require the applicant to furnish the confirmation of the international application by the signature of any applicant for the designated State who has not signed the request and/or any missing indication required under PCT R.4.5(a)(ii) and (iii) in respect of any applicant for the designated State [cf. PCT R.51bis.1(a)(vi) and (vii), respectively].

93 "Changes related to the Patent Law Treaty (PLT): Contents of the International Application; Language of the International Application and Translations; Right of Priority and Priority Claims; Time Limits" (prepared by the International Bureau), Document PCT/R/WG/1/5 (October 2001). See http://www.wipo.int/meetings/en/details.jsp?meeting_id=4446. 
be accorded [Article 5(1) PLT]. The comments and concerns expressed by the various Delegations included the following: ${ }^{94}$

○ the idea of according a filing date under the PCT to an international application without claims was widely supported, but the wording of PCT Article 11(1)(iii)(e) and Article 58 did not support the draft Rules proposed; it would be necessary to develop a proposal to revise the PCT itself;

- to adopt amended PCT Regulations that were so clearly inconsistent with the PCT Articles itself would jeopardize the rights of applicants;

o the PCT provided no basis for adding claims before the international search took place.

As a response to these concerns, the Working Group in Reform of the PCT indicated that it would be prepared to consider other ways of dealing with international applications having no claims pending revision of the PCT itself. The International Bureau indicated that it would attempt to elaborate proposals bearing in mind, in particular, the following possibilities: ${ }^{95}$

○ the PCT distinguishes between the "international application" on the one hand and the "record copy" on the other; different treatment may be able to be accorded to papers according to those different notions;

- advantage might be able to be taken in cases where there is "claim-like" wording appearing in the description; it was noted that the procedure under the European Patent Convention provided for the description to repeat, in effect, the wording of the claims;

○ the request form could include pre-printed wording sufficient to constitute "a part which on the face of it appears to be a claim or claims" for the purposes of PCT Article 11(1)(iii)(e);

- the international search might be able to be undertaken without the presence of formal claims, or on the basis of a "search statement" furnished by the applicant;

- new possibilities being developed for combined search and examination under the PCT might allow for claims furnished under PCT Article 34 to be taken into account for both international search and international preliminary examination.

In addition, proposals in relation to "filing by reference to a previously filed application" were discussed at the first session of the Working Group on Reform of the PCT. The comments and concerns expressed by the various Delegations included the following: ${ }^{96}$

94 "Summary of the session" - "Changes Related to the PLT" (prepared by the Chair), Document PCT/R/WG/1/9 (November 2002), Item 25.

95 "Summary of the session" - "Changes Related to the PLT" (prepared by the Chair), Document PCT/R/WG/1/9 (November 2002), Item 26.

96 "Summary of the session" - "Changes Related to the PLT" (prepared by the Chair), Document PCT/R/WG/1/9 (November 2002), Item 27. 
- some Delegations supported and others opposed the proposal;

- the cases requiring this kind of remedy were rare, and certain Delegations felt that this issue should not have a high priority;

- any proposals in this direction should be coordinated with the proposal for the expanded international search system, where the International Searching Authority, in addition to the International Search Report, establishes a Written Opinion;

- user representatives expressed their support for a proposal which would permit such reference filings under the PCT.

The Working Group agreed that the question of reference filings should be reconsidered in substance and in terms of its priority among the other proposals before the Working Group. ${ }^{97}$

In later sessions of the Working Group on Reform of the PCT priority was given to those matters "which would result in the greatest and most immediate practical benefits for users, having regard also to the degree of complexity involved and to workload implications for Offices and Authorities." In particular, the Working Group focused on proposals concerning restoration of the right of priority and relief when time limits were missed, especially the time limit for entering the national phase..$^{8}$

\subsection{Reform of the PCT - issues not pursued}

During its meeting in October 2005, the Assembly of the "PCT Union" decided to reform the PCT in view of the PLT. ${ }^{99}$ Consequently, a number of amendments of the Regulations under the PCT entered into force on April 1, 2007, relating to the following issues: ${ }^{100}$

- Missing elements and parts of the international application;

- Restoration of the right of priority;

- Rectification of obvious mistakes.

The proposed amendments help applicants to avoid loss of rights in certain circumstances, consistently with the PLT, while maintaining an appropriate balance between the interests of applicants and third parties. ${ }^{101}$

97 "Summary of the session" - "Changes Related to the PLT" (prepared by the Chair), Document PCT/R/WG/1/9 (November 2002), Item 28.

98 "Changes related to the Patent Law Treaty (PLT) - Conform PCT "Missing Part" requirements to those of the PLT" (prepared by the International Bureau), Working Group on Reform of the $P C T$, Document $P C T / R / W G / 4 / 2$ (March 2003), Item 2.

99 "Report", PCT Union, Document PCT/A/34/6 (October 2005). See http://www.wipo.int/meetings/en/details.jsp?meeting_id=goo6.

100 "Proposed Amendments of the PCT Regulations", PCT Union, Document PCT/A/34/2 Rev. (September 2005), Item 1.

See http://www.wipo.int/meetings/en/details.jsp?meeting_id=goo6.

101 Ibid., Item 2 and 10 (i). 
As discussed hereinabove, there was no mitigation of the compulsory presence of claims when filing an international application as prescribed in PCT Article 11(1)(iii)(e) as compared to the exhaustive list of requirements for according a filing date under Article 5(1) PLT. Despite the proposal of the International Bureau to "bend" the PCT Articles by regarding claims as a "legal fiction", such amendment was, eventually, not adopted by the Working Group on the Reform of the PCT and therefore not put before the Assembly of the PCT Union. These differences between the filing date requirements under the PCT as compared to the PLT cause friction. A PLT Contracting Party is obliged to accord a filing date to an application filed in the absence of claims. In addition, no re-dating of the application will take place if the applicant later on supplies a set of claims. However if an applicant files an international application at the same Office, the presence of at least one claim is compulsory and an international filing date will only be accorded when the applicant files at least one claim.

In view of the filing date requirements under the PLT, the PCT allows the filing of a missing part of the description or a missing drawing [cf. PCT Rule 20.5]. In addition, the filing of missing parts may be based on a priority application. Due to the presence of claims being obligatory when filing an international application, it was decided to allow an applicant also to file a missing part of a claim. Moreover, it became possible under the PCT to file a complete set of claims and/or the entire description as a so-called "missing element" [cf. PCT Rule 20.3 and 20.6]. All this resulted in PCT Rule 20 being complicatedly formulated because it encompasses the possibilities of filing missing parts as well as missing elements.

In addition, it was also discussed in relation to filing date requirements, that PCT Rule 20.1(b) could easily have been adapted to incorporate the requirement "allowing the applicant to be contacted" as prescribed in Article 5(1)(ii) PLT.

Not introducing the PLT requirement "filing by reference to a previously filed application" [Article 5(7) PLT] into the PCT seems reasonable because this requirement appears already to have become outdated by advances in transmission technology and would no longer be regarded as a preferred option when filing an international application.

\section{Conclusion}

The incorporation by reference into the Patent Law Treaty (PLT) of so many standards prescribed by the Patent Cooperation Treaty (PCT) as to the form and contents of international applications has not also resulted in the PCT itself being aligned with the basic requirements of the PLT. Due to this incomplete alignment, the relationship between these two international patent law treaties has become a complex one.

In view of earlier amendments to the Regulations under the PCT which already "squeezed" some of the Articles of the PCT, it would have been possible to realize a 
better alignment between the PCT and the PLT. In particular, mitigation of the compulsory presence of claims when filing an international application in view of the requirements in the PLT is desirable and would have been possible. Users of the PCT system would welcome a better alignment of at least some filing date related requirements and provisions dealing with defects which may affect the filing date.

More than once the view has been expressed that the PCT Articles would, at some stage, need to be revised, because there is a limit to the kind of changes which could be achieved by amending the Regulations under the PCT within the boundaries of the provisions of the PCT Articles, and that the manner in which particular changes needed to be implemented would depend on their nature. ${ }^{102}$ In addition, the Working Group on Reform of the PCT extensively discussed the possibilities and consequences of drafting a completely new Treaty encompassing the PCT, the PLT and, possibly also, the Substantive Patent Law Treaty. ${ }^{103}$ At present, all this seems far from realization.

${ }^{102}$ See, e.g., "Summary of the Session" - "Approach to further Reform: Options for Revising the Treaty" (by the Chair), Working Group on Reform of the PCT, Document PCT/R/WG/3/5 (November 2002), Items 6-12, see http://www.wipo.int/meetings/en/details.jsp?meeting_id=4554.

103 "Options for a Possible Revision of the Patent Cooperation Treaty (PCT)" (prepared by the International Bureau), Working Group on Reform of the PCT, Document PCT/R/WG/3/3 (October 2002)

See http://www.wipo.int/meetings/en/details.jsp?meeting_id=4554. 


\section{Chapter V - Periods and remedies under the EPC - Compliance of the EPC with the PLT -}

\section{Part I - Extension of periods and further processing ${ }^{1}$}

\section{Introduction}

Inventors seeking patent protection must initially meet certain formality requirements in order to avoid rejection of their application and consequently loss of rights; these formalities vary from country to country. The Patent Law Treaty ${ }^{2}$ (PLT) aims at harmonizing and streamlining these requirements, offering both inventors and national and regional patent Offices a number of advantages. The PLT does not attempt to harmonise substantive patent laws. Instead, the approach is more to the administrative side of the patent process. The PLT aims at simplifying the rules and make them similar in all Parties to the PLT. The PLT does not establish a completely uniform procedure for all PLT Contracting Parties as a Party is free to require fewer, or more user-friendly, requirements than those prescribed in the $\mathrm{PLT}{ }^{3}$

By aligning national patent laws and regional patent treaties with the PLT, the transparency of the global patent system will significantly improve, in particular for independent inventors and small business enterprises. Generally, entrepreneurs start with filing a patent application (or utility model) on a national level. When seeking patent coverage for the invention in a plurality of countries, a regional patent application or international application should be filed within one year from the filing date of the national application. The Patent Law Treaty, when duly implemented, provides that the requirements for accordance of a date of filing and the possibilities of remedying defects made upon filing while maintaining the accorded date of filing, are more transparent, easier and more straightforward to comply with.

The provisions concerning relief in respect of time limits fixed by the national Office of a PLT Contracting Party, in the form of an extension and/or continued processing, are among the important achievements of the PLT. ${ }^{4}$ The PLT also provides safeguard provisions if an applicant has failed to meet a time limit and, as a consequence, has lost his rights with respect to an application or patent "unintentionally" or in spite of "all due

1 This Chapter is an updated version of an Article: Cees Mulder: "Periods and remedies under the EPC - Compliance of the EPC with the PLT - Part I - Extension of periods and further processing" accepted for publication in European Intellectual Property Review, Issue 1 (2012).

2 The Patent Law Treaty was adopted on 1 June 2000 at a Diplomatic Conference in Geneva; the Treaty entered into force on 28 April 2005. See WIPO Publication No. 258(E).

See http://www.wipo.int/treaties/en/ip/plt/.

3 "Basic Features to the Patent Law Treaty" (prepared by the International Bureau) (November 2006), Item 3.

See http://www.wipo.int/patent-law/en/plt.htm.

4 lbid., Item 38. 
care" required by the circumstances. ${ }^{5}$ In addition, the PLT provides for a remedy for the loss of a priority right in two cases due to innocent non-compliance with related time limits. ${ }^{6}$

The adoption of the PLT is regarded as an encouraging first step toward a global patent system that is consistent, cheap and easy to use. ${ }^{7}$

During the so-called EPC 2000 revision of the European Patent Convention (EPC), the European Patent Organization has opted for a relatively complete implementation into the EPC of the requirements set in the PLT.

This Chapter compares the requirements for relief regarding time limits and the remedy of continued processing under the PLT with their counterparts in the EPC. $\$ 2$ discusses the European Patent Organization as future Contracting Party to the PLT. The requirements for relief in respect of time limits under the PLT, i.e. the extension of time limits fixed by the Office and the related remedy of continued processing, are dealt with in $\$ 3$. The different kinds of periods, including the possible extension of these periods under the EPC, are the subject of $\$ 4$. The remedy of further processing under the EPC is described in $\int 5$.

The requirements in respect of the remedies of reinstatement of rights and restoration of the priority right under the PLT and the corresponding remedy of re-establishment of rights under the EPC are the subject of Chapter VI of this thesis.

\section{Relationship between the EPC and the PLT}

At present, the European Patent Organization is not a Contracting Party to the Patent Law Treaty. The option for Intergovernmental Organisations to become Party to the PLT was created in Article 20(2) PLT. In addition, the European Patent Organization is explicitly mentioned in Article 20(3) and 26 PLT as one of the Regional Patent Organisations that may become Party to the PLT.

In the Basic Proposal for the Revision of the EPC (issued in preparation of the Revision Conference in November 2000), the European Patent Organization indicated its wish to become a Contracting Party to the PLT. ${ }^{8}$ However, this intention was not repeated in the

\footnotetext{
Ibid., Item 42.

Ibid., Item 45.

"How can Patent Offices Encourage Inventive and Innovative Activities?" Document prepared

by Richard J. Apley and presented by Nestor Ramirez (USPTO) at the "Inventors at the Dawn

of the New Millennium: WIPO-IFIA International Symposium", Buenos Aires (September 2000).

See http://www.wipo.int/meetings/en/doc details.jsp?doc id=1468.

8 "Basic Proposal for the Revision of the European Patent Convention"; Document MR/2/00,

"Travaux Préparatoires to the EPC 2000"; comment in relation to Article 80 EPC.

See http://www.epo.org/patents/law/legal-texts/archive/epc200o/travaux/dc-documents.html.
} 
Special Edition on the Revision of the EPC (issued in 2007) although a reference to the earlier document was included. ${ }^{9}$

If the European Patent Organization were to become a PLT Contracting Party, it would be bound by the standards set by the PLT. ${ }^{10}$ In Chapter $V$ and VI the level of compliance of the EPC 2000 with the requirements of the PLT is investigated in relation to the issue of providing relief in respect of periods and the available remedies.

A discussion on the alignment of the EPC with the PLT with respect to the requirements for the accordance of a date of filing including the filing of missing parts of the description and missing drawings and in respect of filing by reference to a previously filed application was published elsewhere. ${ }^{11-12}$

\section{Relief in respect of time limits - Article 11 and Rule 12 PLT}

Article 11 of the PLT governs the requirements for the extension of time limits and for "continued processing" of an application or a patent. This Article obliges a PLT Contracting Party to provide relief in respect of time limits. Such relief may be in the form of an extension of the time limit [Article 11(1) PLT] and/or continued processing [Article 11(2) PLT]. ${ }^{13}$ The relief in respect of the time limit is subject only to the filing of a request in accordance with the requirements of Article 11(1) or (2) PLT and Rule 12 PLT, and, where applicable, to the payment of a fee [Article 11(4) PLT]. Accordingly, the applicant or owner concerned may not be required to state the grounds on which the request is based or to file evidence with the Office [Article 11(5) PLT] ${ }^{14}$ In particular, a PLT Contracting Party is not permitted to make the grant of relief under Article 11 PLT

9 "Revision of the European Patent Convention (EPC 2000). Synoptic presentation EPC 1973/2000 - Part l: The Articles", EPO Official Journal 2007, Special Edition No. 4; comment in relation to Article 120 EPC.

See http://www.epo.org/patents/law/legal-texts/journal/2007.html.

10 The European Patent Organization seems not to be in a hurry to ratify as they want to keep all options open, including the option to change the EPC Implementing Regulations in deviation from the PLT.

11 Cees Mulder and Derk Visser: "Filing date requirements under the EPC - an option to extend subject-matter?", epi Information 2|10, pp. 44-48. An updated version of this article is included in Chapter II of this thesis.

See http://www.patentepi.com/patentepi/en/Information/epi-information.php.

12 Cees Mulder and Derk Visser: "Filing date requirements under the EPC - filing by reference to a previously filed application", epi Information 4|10, pp. 126-129. An updated version of this article is included in Chapter III of this thesis.

See http://www.patentepi.com/patentepi/en/Information/epi-information.php

13 "Explanatory Notes on the Patent Law Treaty and Regulations under the Patent Law Treaty adopted by the Diplomatic Conference on June 1, 2000" (prepared by the International Bureau), Diplomatic Conference for the Adoption of the PLT, Document PT/DC/48 Prov. (November 2000), Note 11.01.

See http://www.wipo.int/meetings/en/details.jsp?meeting_id=4057.

14 Ibid., Note 11.08. 
conditional on a finding of due care or unintentionality by the Office (= authority of the PLT Contracting Party entrusted with the granting of patents). ${ }^{15}$

The relief a PLT Contracting Party is obliged to provide under Article 11(1) and (2) PLT is restricted to time limits "fixed by the Office for an action in a procedure before the Office" ${ }^{16}$ It is for each PLT Contracting Party to decide which time limits are fixed by the Office. A typical example of a time limit fixed by Offices is the time limit for response to an examiner's substantive examination report. It follows that Article 11 PLT does not apply to time limits that are not fixed by the Office, in particular, time limits established by national legislation or under a treaty providing for the grant of regional patents. ${ }^{17}$

The text of Article 11(2) PLT in relation to continued processing refers to another method of relief (emphasis added):

Where an applicant or owner has failed to comply with a time limit fixed by the Office of a Contracting Party for an action in a procedure before the Office in respect of an application or a patent, and that Contracting Party does not provide for extension of a time limit under paragraph (1)(ii), the Contracting Party shall provide for continued processing with respect to the application or patent and, if necessary, reinstatement of the rights of the applicant or owner with respect to that application or patent, if ...

There is no explanation in the Explanatory Notes on the PLT about the meaning of the wording "if necessary" in relation to the applicability of the remedy reinstatement of rights. However, in the "Summary Minutes of the Main Committee I" it was explained by a representative of WIPO: ${ }^{18}$

"The reason for using the word 'if necessary' in respect of continued processing was that under different national systems providing for continued processing, some considered that the rights had been lost upon the expiration of the time limit and others consider those rights only to be lost upon the expiration of the period for requesting continued processing. Therefore, in some cases, rights would have to be reinstated and in other cases the rights would not have to be reinstated and there would simply be continued processing."

\subsection{Extension of time limits}

Article 11(1) PLT obliges a PLT Contracting Party to provide for relief in the form of the extension of a time limit fixed by the Office. A PLT Contracting Party may either require that the request for extension be filed before the expiration of that time limit

15 Ibid., Note 11.01.

16 Ibid., Note 11.02.

17 Ibid., Note 11.02.

18 Summary Minutes of the Main Committee I (prepared by the International Bureau); $14^{\text {th }}$ session (Monday, May 22, 2000, afternoon); published in Records of the Diplomatic Conference for the Adoption of the Patent Law (Geneva, 2000) (WIPO Publication 327E), p. 414, Item 1226. 
[Article 11(1)(i) PLT] or that the request be filed after that expiration but within a prescribed time limit [Article 11(1)(ii) and Rule 12(2)(b) PLT]. ${ }^{19}$ A PLT Contracting Party may, in principle, provide for both types of relief under Article 11(1)(i) and (ii) PLT. The requirements in respect of the request, the period of the extension, and the time limit for filing a request referred to in Article 11(1)(ii) PLT are prescribed in Rule 12(1) and (2) PLT. ${ }^{20}$

Article 11(1) PLT does not oblige a PLT Contracting Party to provide for the extension of a time limit fixed by the Office under either Article 11(1)(i) or (ii) PLT. However, a PLT Contracting Party that does not provide for extension after expiration of the time limit [Article 11(1)(ii) PLT] is obliged to provide for continued processing under Article 11(2) PLT in respect of these time limits. ${ }^{21}$

Requirements for a request for extension are given in Rule 12(1) PLT. In particular, a PLT Contracting Party may require that the request under Article 11(1) PLT be signed by the applicant or owner [Rule 12(1)(a)(i) PLT]; a representative may sign on behalf of the applicant or owner. ${ }^{22}$ In addition, it may be necessary to indicate to what time limit the extension relates [Rule 12(1)(a)(ii) PLT].

Where a request for extension of a time limit is filed after expiration of the time limit [Article 11(1)(ii) PLT], a PLT Contracting Party may require that all of the requirements in respect of which the time limit for the action concerned applied be complied with at the same time as the request is filed [Rule 12(1)(b) PLT].

\subsection{Continued processing}

Article 11(2) PLT obliges a PLT Contracting Party to provide for relief in the form of continued processing, after the applicant or owner has failed to comply with a time limit fixed by the Office, where that Contracting Party does not provide for the extension of time limits under Article 11(1)(ii) PLT. ${ }^{23}$ The effect of such continued processing is that the Office continues the procedure concerned as if that time limit had not been missed.

Requirements for a request for continued processing are given in Article 11(2)(i) and Rule 12(3) PLT and the time limit for filing the request and to meet all the requirements are given in Article 11(2)(ii) and Rule 12(4) PLT. In particular, a PLT Contracting Party may

19 "Explanatory Notes on the Patent Law Treaty and Regulations under the Patent Law Treaty adopted by the Diplomatic Conference on June 1, 2000" (prepared by the International Bureau), Diplomatic Conference for the Adoption of the PLT, Document PT/DC/48 Prov. (November 2000), Note 11.03. According to Rule 12(2)(b) PLT, the time limit to request extension must be at least 2 months from the date of expiration of the unextended time limit.

20 Ibid., Note 11.03: A Contracting Party may, under Rule 12(1)(b) PLT, require that all requirements for the extension of the time limit are complied with at the same time as the request under Article 11(1)(ii) PLT is filed.

${ }^{21}$ Ibid., Note 11.04.

22 Ibid., Note R12.01.

23 Ibid., Note 11.05. 
require that the request be signed by the applicant or owner [Rule 12(3)(i) PLT]; a representative may sign on behalf of the applicant or owner. ${ }^{24}$ In addition, it may be required to indicate that continued processing in respect of non-compliance with a time limit is requested, including an indication of the time limit in question [Rule 12(3)(ii) PLT]. The time limit for filing the request for continued processing must be at least 2 months after a notification by the Office that a time limit was not complied with [Rule 12(4) PLT].

\subsection{Exceptions}

Article 11(3) PLT lists procedures in respect of which a PLT Contracting Party is not obliged to provide for the extension of a time limit fixed by the Office [Article 11(1) PLT] or for continued processing after failure to comply with a time limit fixed by the Office [Article 11(2) PLT], although it is permitted to do so. ${ }^{25} \mathrm{~A}$ list of these exceptions is given in Rule 12(5)(a) PLT:

(i) A PLT Contracting Party is not obliged to grant more than one instance of relief under Article 11(1) or (2) PLT, although it is permitted to do so. Similarly, a PLT Contracting Party is not obliged to grant continued processing under Article 11(2) PLT after an extension of the time limit concerned has been previously granted under Article 11(1) PLT. Any second or subsequent instance of relief that is granted by a PLT Contracting Party is not regulated by Article 11(1) or (2) or Rule 12 PLT. ${ }^{26}$

(ii) This item is intended to prevent an applicant or owner from obtaining double relief for filing a request for the extension of an Office time limit [Article 11(1) PLT], continued processing [Article 11(2) PLT] or for reinstatement of rights. ${ }^{27}$

(iii) A PLT Contracting Party is not obliged to provide for the extension of, or continued processing in respect of, a time limit fixed by the Office for the payment of maintenance fees. However, a period of grace for the payment of such fees must be provided [Article 5 bis(1) Paris Convention]. ${ }^{28}$

(iv) A PLT Contracting Party is not obliged under Article 11(1) or (2) PLT to grant relief in respect of a time limit for requesting reinstatement of rights [ $c f$. Article 13(1), (2) or (3) PLT]. ${ }^{29}$

(v) A PLT Contracting Party is not obliged under Article 11(1) or (2) PLT to grant relief in respect of a time limit for an action before a Board of Appeal or other review body constituted in the framework of the Office.

(vi) A PLT Contracting Party is not obliged under Article 11(1) or (2) PLT to grant relief in respect of a time limit for an action in inter partes proceedings. ${ }^{30}$ 


\subsection{Opportunity to make observations}

Article 11(6) PLT gives the requesting party the right to make observations on the intended refusal of a request under Article 11(1) or (2) PLT, for example, to assert that a fee in relation to a request for continued processing [Article 11(4) PLT] has been paid in time. The term "refusal" is meant also to cover sanctions having an equivalent effect to refusal of the request to extend a time limit, such as the request being treated as abandoned or withdrawn. ${ }^{31}$

\section{Periods under the EPC - Article 120 and Rule 132 EPC}

The EPC distinguishes two types of periods: the so-called "Office periods" and "Convention periods", depending on whether the duration of the period is specified by the EPO or fixed in an Article or Rule of the EPC, respectively.

In the revision of the European Patent Convention (EPC) in 2000, Article $120 \mathrm{EPC}^{32}$ was redrafted to clarify its meaning. In particular, Article 120(a) EPC states that any periods the duration of which is not fixed in an Article of the EPC and which have to be observed in proceedings before the European Patent Office (EPO) are to be specified in the EPC Implementing Regulations. ${ }^{33}$

\subsection{The use of the terms "time limit" and "period" in the EPC}

The English version of the European Patent Convention uses the term "time limit" and the word "period" for the same notion whereas the German and French version of the EPC systematically use the word "Frist" and "délai", respectively. The confusing terminology in the English version of Rule 83 EPC 1973 (now Rule 131 EPC) was recognised in the decision of the Legal Board of Appeal J 18/04; the Board decided that "time limit" and "period" are to be regarded as equivalents. ${ }^{34}$

When adopting the Implementing Regulations to the EPC under the EPC 2000, the EPO decided to replace the term "time limit" by "period"; this operation was not entirely

${ }^{31}$ Ibid., Note 11.09.

32 In this Chapter, all references to the EPC are to the EPC 2000 unless otherwise indicated.

33 "Revision of the European Patent Convention (EPC 2000). Synoptic presentation EPC 1973/2000 - Part I: The Articles", EPO Official Journal 2007, Special Edition No. 4i comment in relation to Article 120 EPC.

34 Decision Legal Board of Appeal J 18/04, see reasons 21-26.

See: http://legal.european-patent-office.org/dg3/pdf/j040018ex1.pdf.

In Reason 26 of $\mathrm{J} 18 / 04$ the Legal Board of Appeal noted that: "This interpretation of the term 'time limit' is also wholly in line with the provisions of the European Convention on the Calculation of Time-Limits (Basle Convention of 16 May 1972, in force since 28 April 1983): see especially Articles 2,3 and 4. The Board notes that several Member States of the EPC are also signatories to the Basle Convention, which, therefore, also may be taken into account pursuant to Article 125 EPC when the meaning of the term 'time limit' is to be determined, as is the case here. It is noteworthy that the Explanatory Report to the Basle Convention explains that the wording 'time limit' was chosen as the English term for the French term 'délai'." 
successful. ${ }^{35}$ In the Articles of the EPC 2000, the term "time limit" was not replaced by the word "period".

In this Chapter, the term "time limit" will be used in relation to the PLT and the word "period" in relation to the EPC.

\subsection{Periods to be specified by the EPO}

The basis for the concept of Office periods is laid down in Article 120(a) EPC. Rule 132(1) EPC gives a definition of an Office period: where the EPC Articles or Rules refer to "a period to be specified", the duration of this period is to be specified by the EPO.

Examples of Office periods in the EPC Implementing Regulations are: ${ }^{36}$

- the period for supplying a translation of the priority application [Rule 53(3) EPC],

o the period for correcting deficiencies in the priority claim [Rule $59 \mathrm{EPC}$ ],

o the period for inviting the applicant to indicate whether he desires to proceed further with the European patent application [Rule 70(2) EPC],

0 the period for responding to a communication from the Examining Division [Rule 71(1) EPC],

o the period for correcting deficiencies in the request for limitation [Rule 94 EPC], and

o the period for correcting deficiencies in the notice of appeal [Rule 101(2) EPC].

There appears to be a tendency to reduce the number of "periods to be specified" in the EPC Rules in line with the desire of the EPO to streamline the grant procedure. ${ }^{37}$ The term "a period to be specified" was deleted from Rule 51(4) EPC 1973 [entry into force on 1 April 2005; now Rule 71(3) EPC 2000]. Upon the entry into force of the EPC 2000, the term "a period to be specified" could also be found in Rules 64(1) and 141 EPC; as a result

35 The title of Chapter V of Part VII of the Implementing Regulations to the EPC is "Time limits". The replacement of "time limit" by "period" was omitted in Rules 50(3), 58(3) and 82(3) EPC and overlooked when adopting Rules 51(4), 135(1) and 136(1) EPC. In addition, the term "period of grace" was replaced by the term "time limit" in Rules 45(2) and 162(2) EPC. To confuse things further, the term "a time limit of 24 months" was used when inserting Rule 36(1)(a) and (b) EPC.

36 Beyond Rule 132(1) EPC, the term "a period to be specified" occurs 20 times in the EPC Implementing Regulations [situation 1 May 2011], i.e. in Rules 3(3), 5, 53(3), 59, 60(2), 70(2), 71(1), 71(5), 77(2), 79(1), 79(3), 81(2), 94, 95(2), 100(2), 101(2), 108(2), 118(2)(c), 151(2) and 152(2). In addition, the term "a period to be specified" occurs in Article 7(4) of the Rules Relating to Fees. Note that a different expression to the same effect is used in Rule 120(1) EPC ("the period specified in the summons") and Rule 121(2)(b) EPC ("the period specified for the submission of his opinion").

37 By removing the possibility to extend Office periods, the EPO desires to shorten the overall duration of the proceedings. However, it seems that the bar is raised only for applicants. 
of later amendments, the duration of the period is now fixed in these Rules..$^{38}$ In addition, current Rule 71(5) EPC containing the wording "a period to be specified" will be deleted effective 1 April 2012.

\subsubsection{Extension of Office periods}

Rule 132(2) EPC specifies a duration of 2 to 4 months for an Office period; in "certain circumstances" the period may be up to 6 months. The current practice at the EPO is that a 2-month period will be specified for correcting deficiencies which are merely formal or of a minor character. The upper limit of 4 months is used in communications from an Examining Division or Opposition Division raising matters of substance. A longer period of up to 6 months will be set by the EPO only in exceptional cases where it is clear that a 4-month period cannot be adhered to. ${ }^{39}$

The "unless otherwise specified" in Rule 132(2) EPC allows that a provision in the EPC may permit the EPO to set the duration of an Office period shorter than the minimum duration of 2 months. An example of such provision can be found in Rule 109(1) EPC in relation to petition for review proceedings (see $\$ 4.2 .2) \cdot{ }^{40}$

Under Rule 132(2) EPC, second sentence, the period may be extended upon request if the request is filed before the expiry of such a period. In spite of the wording "in special cases" in Rule 132(2) EPC, second sentence, the request for extension, even if filed without reasons, is normally allowed if the total period does not exceed 6 months. ${ }^{41}$ However, a request for an extension, resulting in a total period exceeding 6 months, will be allowed only exceptionally, when the reasons given are sufficient to show convincingly that a reply in the period previously given will not be possible. ${ }^{42}$

Periods are automatically extended if the period expires on a day on which one of the EPO filing Offices is not open for receipt of documents or on which mail cannot be delivered; the period is extended to the first day thereafter on which all the filing Offices are open again [Rule 134(1) EPC]. This provision also applies if documents filed by

${ }^{38}$ Rule 64(1) EPC (lack of unity) was amended effective 1 April 2010. In Rule 64(1) EPC as in force before that date the applicant was given "a period to be specified which shall neither be shorter than two weeks nor exceed six weeks".

Rule 141 EPC (information on prior art) was amended effective 1 January 2011. In Rule 141 EPC as in force before that date the applicant was given "a period to be specified".

39 Guidelines for Examination in the European Patent Office (April 2010), Part E, Chapter VIII, \$1.3, see http://www.epo.org/patents/law/legal-texts/guidelines.html.

40 Another example can be found in Rule 116(1) EPC (preparation of oral proceedings) stating: "Rule 132 shall not apply." Note that Rule 116(1) EPC does not refer to a "period" but to a "final date". Also see the decision of the Legal Board of Appeal J 14/91 where the Board considered it sufficient to give the parties 20 days' advance notice of the oral proceedings.

See http://www.epo.org/law-practice/case-law-appeals/recent/j910014ep1.html

${ }^{41}$ Guidelines for Examination in the European Patent Office (April 2010), Part E, Chapter VIII, \$1.6.

42 Ibid., Part E, Chapter VIII, \$1.6. 
technical means of communication [Rule 2(1) EPC] cannot be received by the EPO [Rule 134(1) EPC, last sentence].

\subsubsection{EPC Office periods versus PLT Office time limits}

The "period to be specified by the European Patent Office" in Rule 132(1) EPC is equivalent to the "time limit fixed by the Office" as referred to in Article 11 PLT. The EPO follows Article 11(1)(i) PLT in that a request for extension of a period has to be filed prior to expiry of the period [Rule 132(2) EPC].

With respect to the exceptions listed in Article 11(3) PLT for which a PLT Contracting Party need not provide relief in the form of extension of a time limit fixed by the Office as well as with respect to continued processing [Rule 12(5)(a)(i) PLT], the EPO nevertheless allows, in many cases, an applicant to request an extension of an Office period and to, subsequently, file a request for further processing (also see $\ 5 \cdot 3$ ).

A typical example (and frequently used by applicants) of allowing a request for extension followed by further processing, is the communication under Rule 71(1) EPC, where the Examining Division pursuant to Article 94(3) EPC, requests the applicant to correct any deficiencies noted in the European patent application and to amend the description, claims and drawings within "a period to be specified". If matters of substance are raised in this communication, the Examining Division will set a period of 4 months for response to this communication. ${ }^{43}$ If the applicant files a request for an extension of the period, the EPO will allow the applicant 2 months extra to answer the communication [Rule 132(2) $E P C]$. The request for extension must be filed before expiry of the normal period [in line with Article 11(1)(i) PLT] and no reason for the extension need be given [in line with Article 11(5) PLT]. The extended period is to be calculated from the start of the original period..$^{4-45}$ Failure to reply to the communication in due time will cause the European patent application to be deemed to be withdrawn [Article 94(4) EPC]. The EPO will notify the applicant by issuing a loss of rights communication [Rule 112(1) EPC].$^{46}$ The common remedy is to file a request for further processing [Article 121 and Rule $135 \mathrm{EPC}$ ]. ${ }^{47}$ The request for further processing has to be filed within 2 months from the notification of the loss of rights communication [in line with Rule 12(4) PLT].

The EPO does not levy a fee for requesting extension of an Office period (as would be allowed by Article 11(4) PLT). As all documents filed after filing the European patent application must be signed [Rule 50(3) EPC], the requirements for requesting an extension of an Office period are in line with Rule 12(1)(i) PLT. In addition, the EPO does

43 Ibid., Part C, Chapter VI, \10.1 and Part E, Chapter VIII, \1.2 (ii).

44 Ibid., Part E, Chapter VIII, \$1.6.

45 When the original period was extended under Rule 134 EPC, there could be a non-respect of Rule 12(2)(a)PLT that provides a minimum of 2 months from the expiration of the unextended time limit (Rule 133 EPC only provides for a deemed timely receipt, not for an extension).

46 Guidelines for Examination in the European Patent Office (April 2010), Part E, Chapter VIII, \$1.9.

47 Ibid., Part E, Chapter VIII, \2.1. 
not require any other requirements to be complied with when a request for extension is filed, thereby complying with Article 11(5) PLT.

The EPO is not required to grant relief in respect of a period for an action before a Board of Appeal or other review body constituted in the framework of the Office [Article 11(3) and Rule 12(5)(a)(v) PLT] nor in respect of a period for an action in inter partes proceedings [Rule 12(5)(a)(vi) PLT]. Nevertheless, the EPO grants requests for extension of any "period to be specified" during opposition proceedings [cf. Rules 77(2), 79(1), 79(3) and 81 (2) EPC] and subsequent appeal proceedings [cf. Rules 100(2) and 101(2) EPC].$^{48}$ In addition, the EPO will allow requests for extension of any "period to be specified" during post-grant limitation proceedings [cf. Rules 94 and 95(2) EPC].

There is only one exception: Rule 109(1) EPC rules out the application of Rule 132(2) EPC in proceedings in relation to petitions for review by the Enlarged Board of Appeal [Article 112a EPC]. ${ }^{49}$ Therefore, a request for an extension of the "period to be specified" in Rule 108(2) EPC will normally be refused; this is in line with Rule 12(5)(a)(v) PLT.

In line with what is prescribed in Article 11(6) PLT, the EPO provides an opportunity to make observations when a request for an extension of an Office period is to be rejected. This is based on the general principle in the EPC, that decisions of the EPO may only be based on grounds or evidence on which the parties concerned have had an opportunity to present their comments [Article 113(1) EPC].

Where the EPO rejects an applicant's request for an extension of an Office period which has been filed in good time, and the applicant considers this unjust, the ensuing loss of rights can only be overcome by requesting further processing [Article 121(1) and Rule 135(1) EPC]. At the same time, the applicant may request reimbursement of the fee for further processing. A decision rejecting the request for reimbursement is open to appeal, either together with the final decision or separately, as the case may be [Article 106(2) EPC]..$^{\circ}$

\subsection{Convention periods}

A Convention period is a period of which the duration is fixed in the EPC Articles or its Implementing Regulations. Examples of Convention periods in the EPC Articles are:

o the 12-month period for claiming priority [Article 87(1) EPC],

o the 9-month period for filing an opposition [Article 99(1) EPC],

$4^{8}$ According to Article 12(5) of the Rules of Procedure of the Boards of Appeal: "Extension of time limits may exceptionally be allowed in the Board's discretion following receipt of a written and reasoned request."

See http://archive.epo.org/epo/pubs/ojo07/11_07/11_5367.pdf.

49 The current practice is that the Enlarged Board of Appeal sets a period of about 1 month under Rule 109(1) EPC in the first stage of the review proceedings.

50 Guidelines for Examination in the European Patent Office (April 2010), Part E, Chapter VIII, \$1.6. 
0 the 2-month period for filing a notice of appeal and the 4-month period for filing the statement setting out the grounds of appeal [Article $108 \mathrm{EPC}$, and

0 the 2-month and 5-year period for filing a petition for review [Article 112a(4) EPC].

Examples of Convention periods in the EPC Implementing Regulations are: $:^{51}$

O the 24-month period for filing a divisional application [Rule 36(1)(a) and (b) EPC],

0 the 1-month period for payment of the filing and search fee [Rule 38(1) EPC],

0 the 6-month period for payment of the designation fee and the examination fee [Rule 39(1) and 70(1) EPC, respectively],

$\circ$ the 2-month period for filing copies of the search results of a priority application [Rule 7ob(1) EPC],

o the 4-month period for paying the fee for grant and publishing and to file a translation of the claims [Rule 71(3) EPC],

$\circ$ the 31-month period for fulfilling the requirements for entry into the regional phase of an international application before the EPO [Rule 159(1) EPC],

o the 6-month period for filing a response to the written opinion, correcting deficiencies and filing amendments in respect of a Euro-PCT application for which the EPO in the international phase acted as International Searching Authority, as International Searching Authority competent to carry out Supplementary International Searches or as International Preliminary Examining Authority [Rule 161(1) EPC].

\subsubsection{Extension of Convention periods}

Since the extension of a period under Rule 132(2) EPC only applies to "a period to be specified" by the EPO, a period of which the duration is fixed in the EPC cannot be extended on request. ${ }^{52}$ However, such a period may be extended automatically under Rule 134 EPC.

\subsubsection{EPC Convention periods and PLT time limits}

Article 11 PLT only provides for relief in respect of time limits fixed by the Office. Hence, the EPO need not provide for the extension of Convention periods in view of the PLT. ${ }^{53}$

\section{Further processing under the EPC - Article 121 and Rule 135 EPC}

In the EPC 2000 revision, the scope of application of further processing was broadened in order to make it the standard legal remedy in cases of failure to observe periods in the

$5^{1}$ The EPC Implementing Regulations in the version as in force as of 1 May 2011.

52 Guidelines for Examination in the European Patent Office (April 2010), Part E, Chapter VIII, \$1.6.

53 "Explanatory Notes on the Patent Law Treaty and Regulations under the Patent Law Treaty adopted by the Diplomatic Conference on June 1, 2000" (prepared by the International Bureau), Diplomatic Conference for the Adoption of the PLT, Document PT/DC/48 Prov. (November 2000), Note 11.02. 
procedure up to the grant of the European patent. ${ }^{54}$ Further processing nowadays applies to the periods for the payment of the filing fee and search fee [Rule $38 \mathrm{EPC}]$, the designation fee [Rule $39 \mathrm{EPC}$ ] and for the filing of the request for examination [Rule 70 $E P C]$, all of which were excluded therefrom under the EPC $1973 .{ }^{55}$

Further processing is the main remedy under the EPC for the non-observance of a period before the EPO. However, the availability of this remedy under the EPO is limited to grant proceedings and to appeal proceedings after refusal of the application, because of the reference to "applicant" and "application" in Article 121(1) EPC (italics added): "If an applicant fails to observe a time limit vis-à-vis the EPO, he may request further processing of the European patent application." Hence, further processing is not available after grant of the European patent, e.g. in opposition proceedings, inter partes appeal proceedings and ex parte limitation proceedings.

Article 11 PLT also relates to patents. In principle, the EPC should offer further processing to patentees or opponents. However, in view of the exceptions listed in Rule 12(5)(v) and (vi) PLT [see $\$ 3.3$ ], a PLT Contracting Party is not obliged to grant relief in respect of a time limit for an action in inter partes proceedings. However, as limitation/revocation proceedings are ex parte proceedings, the EPC is not conforming to the PLT by not providing further processing if the patent proprietor fails to observe a period vis-à-vis the EPO in such proceedings. In particular, if a request for limitation or revocation [Article 105a EPC] is rejected as inadmissible by the EPO [Rule 94 EPC], the EPC should allow the proprietor to request further processing in the missed Office period. ${ }^{56}$

Article 121(2) EPC provides that a request for further processing is to be granted where the requirements laid down in the EPC Implementing Regulations are met [Rule 135(1) $E P C]$. If the request for further processing is granted, the European patent application will be treated as if the non-observance of the period had not happened [Article 121(3) $E P C]$.

In principle, further processing is available both for Office periods (see $\ 5.1$ ) and for Convention periods (see $\ 5.2$ ). Further processing is excluded for specific periods mentioned in Article 121(4) and Rule 135(2) EPC.

It should be noted that the applicability of further processing does not depend on the nature of the sanction ensuing after non-observance of a period. It is irrelevant whether

54 "Revision of the European Patent Convention (EPC 2000). Synoptic presentation EPC 1973/2000 - Part I: The Articles", EPO Official Journal 2007, Special Edition No. 4; comment in relation to Article 121 EPC.

55 The use of the wording "failure to reply within a time limit set by the EPO" in Article 121(1) EPC 1973 excluded the Convention periods in Article 78(2) (filing and search fee), Article 79(2) (designation fees) and Article 94(2) (request for examination) EPC 1973 from further processing.

${ }^{5}$ Note that the European patent is not lost when the request for limitation/revocation is rejected as inadmissible. The patent proprietor can file a new request for limitation/revocation. 
the sanction is a total loss of rights such as the refusal of the European patent application [Article 9o(5) EPC] or a partial loss of rights such as the loss of a priority claim [Article 90(5) EPC, last sentence]. ${ }^{57}$ However, the refusal of a European patent application under Article 97(2) EPC cannot be remedied using further processing, because in this case the refusal does not directly follow a failure to observe a period, as required by Article 121(1) EPC, but non-compliance of the application with a requirement of the EPC. In the latter case, the appropriate legal remedy is to file an appeal against the refusal [Articles 106 and $108 \mathrm{EPC} .^{5^{8}}$

\subsection{EPC Office periods and further processing}

If "a period to be specified" by the EPO is missed in grant proceedings or in ex parte appeal proceedings, further processing may be requested. There is only one exception in the EPC: further processing is ruled out if the applicant does not respond in due time to an invitation to repair deficiencies in the priority claim under Rule 59 EPC [ $c f$. Rule 135(2) $E P C]$. The period for response in Rule 59 EPC is an Office period, set by the EPO between 2 and 4 months. ${ }^{59}$ The EPO issues an invitation under Rule 59 EPC if the applicant has not complied with the 16-month period of Rule 52(2) EPC in relation to the file number of the previous application or with the 16-month period of Rule 53(1) EPC in relation to supplying a copy of the priority document. According to the EPO, the procedure under Rule 59 EPC already constitutes a form of legal remedy. ${ }^{60-61}$

\subsection{Convention periods and further processing}

Article 11 PLT only provides for relief in respect of time limits fixed by the Office. Hence, the EPO need not provide for further processing in relation to Convention periods in view of the PLT. Nevertheless, in many cases the EPO allows an applicant to file a request for further processing if a Convention period has not been observed. However, there is an extensive list of Convention periods for which further processing is ruled out.

57 Guidelines for Examination in the European Patent Office (April 2010), Part E, Chapter VIII, $\$ 2.1$.

$5^{8}$ Ibid., Part C, Chapter VI, \$ 7.6. Also see Rule 111(2) EPC.

59 Ibid., Part A, Chapter III, $\ 16.2$.

60 "Revision of the European Patent Convention (EPC 2000). Synoptic presentation EPC 1973/2000 - Part II: The EPC Implementing Regulations", EPO Official Journal 2007, Special Edition No. 5; comment in relation to Rule 59 EPC.

See http://www.epo.org/patents/law/legal-texts/journal/2007.html.

${ }_{61}$ Whether or not Rule 59 EPC itself constitutes a form of legal remedy, providing "a period to be specified" implies that further processing should be given; any other option is a non-conformity to PLT. If the EPO didn't want to give further processing, they could simply have inserted a fixed period in Rule 59 EPC. However, specifying a period to be specified has the advantage that it can be extended upon request, possibly beyond 6 months with the submission of good reasons why the submission of the priority document is late. Such reasons would be the same as used in supporting a request for re-establishment of rights, with less formalities and no fee. On the other hand, providing for further processing has the disadvantage that the applicant would (under the present interpretation and practice) have to file for re-establishment as well as for further processing. 
The following periods in the EPC Articles are excluded from further processing [Article 121(4) EPC]:

- The 12-month priority period [Article 87(1) EPC],

0 The 2-month and 4-month periods in relation to filing an appeal [Article $108 \mathrm{EPC}$ ],

o The 2-month periods and the 5-year period in relation to filing a petition for review [Article 112a(4) EPC], and

- The periods for requesting further processing and re-establishment of rights [Article 121 and 122 EPC, respectively].

The more elaborate remedy of re-establishment of rights which involves proving all due care is possible in respect of all the above periods except for the period for requesting re-establishment of rights (to avoid chaining of remedies).

Further exceptions to applying further processing are listed in the EPC Implementing Regulations [Rule 135(2) EPC]. According to the EPO, the purpose of these exceptions is not to enable the scope of application of further processing to be generally restricted. Only if an adequate legal remedy (meeting the requirements of the PLT) was already provided by the law would it be possible to rule out application of Article 121 EPC. ${ }^{62}$

Approximately half of the periods in the EPC Implementing Regulations are excluded from further processing according to Rule 135(2) EPC. There is a variety of reasons behind these exclusions. In line with the exceptions listed in Rule 12(5)(a)(i) PLT, the general approach under the EPC is that there should be no accumulation of legal remedies. For example: where a means of legal redress already exists for dealing with the non-observance of a period, also allowing further processing would create a two-tier system for rectifying the error at the first-instance stage. This type of reasoning applies, for instance, to the following periods: ${ }^{63}$

O The 2-month period in Rule 6(1) EPC for filing a translation under Article 14(2) EPC has been excluded because the failure to meet this time limit may be remedied under Rule 58 EPC [ $c f$. Rule 57(a) EPC]. The same applies for the 2-month period in Rule 36(2) EPC for filing a translation of a divisional application.

- The 2-month period in Rule 40(3) EPC for filing a certified copy of the previously filed application has been excluded because the failure to meet this time limit may be remedied under Rule 55 EPC. In addition, the 2-month period of Rule 40(3) EPC for filing a translation of the previously filed application has been excluded because

62 "Conference of the Contracting States to revise the 1973 European Patent Convention", Munich, 20 to 29 November 2000, Conference Proceedings, MR/24/00 (15 July 2003); p. 94.

See

http://www.epo.org/patents/law/legal-texts/archive/epc2000/diplomatic-conference-nov2000 .html.

63 "Revision of the European Patent Convention (EPC 2000). Synoptic presentation EPC 1973/2000 - Part II: The EPC Implementing Regulations", EPO Official Journal 2007, Special Edition No. 5; comment in relation to Rule 135 EPC. 
the failure to meet this time limit may be remedied under Rule $5^{8} \mathrm{EPC}[c f$. Rule 57(a) EPC].

$\circ$ The 2-month period in Rule 55 EPC relating to the examination on filing [Article 9o(1) and (4) EPC] has been excluded, because the procedure under this Rule already constitutes a form of legal remedy. The same applies to the 2-month period in Rule 56 EPC in relation to the subsequent filing of missing parts of the description or missing drawings and to the 2-month period in Rule 58 EPC in relation to correcting deficiencies after formalities examination [Article 90(3) and (4) EPC].

Some periods are excluded from further processing, because failure to comply with the period does not result in the EPO issuing a communication. ${ }^{64}$ This applies, for instance, to the following periods: ${ }^{65}$

- The 3-month period in Rule 16(1)(a) EPC for seeking remedies under Article 61 EPC (entitlement proceedings) has been excluded, because it is not monitored by the EPO and no communication can be issued if it is missed. If this period is missed, the entitled person under Article 61(1) EPC can apply for re-establishment of rights.

O The 2-month period in Rule 112(2) EPC in connection with the request for an appealable decision has been excluded, because this provision allows for an administrative review of any loss of rights resulting from the EPC.

Some periods are excluded from further processing because failure to comply with the period and allowing further processing would postpone or delay the procedure needlessly. This type of reasoning applies, for instance, to the following periods: ${ }^{66}$

- The 16-month period in Rule 52(2) EPC for late filing of the declaration of priority and the 16-month and 4-month periods in Rule 52(3) EPC in relation to correcting the declaration of priority have been excluded in view of the publication of the application [Article 93 EPC]. For reason of legal certainty, the information in relation to Rule 52(2) and (3) EPC should be available in due time for inclusion in the publication of the European patent application.

- The 2-month period in Rule 62a(1) EPC to indicate the claims complying with Rule 43(2) EPC (several independent claims in one category) on which the search is to be based has been excluded to allow the European search report to be available in time to be published together with the application. The same applies for the

64 The wording of Rule 135(1) EPC implies that further processing can only be requested when the EPO issues a communication concerning either the failure to observe a period or a loss of rights.

65 "Revision of the European Patent Convention (EPC 2000). Synoptic presentation EPC 1973/2000 - Part II: The EPC Implementing Regulations", EPO Official Journal 2007, Special Edition No. 5i comment in relation to Rule 135 EPC.

66 Ibid., comment in relation to Rule 135 EPC. 
2-month period in Rule 63(1) EPC (carrying out a meaningful search) for filing a statement indicating the subject-matter to be searched. ${ }^{67}$

Some periods are excluded from further processing because the EPO sees no need for allowing further processing. This type of argument is used, for instance, in relation to the following periods: ${ }^{68}$

O The 24-month period of Rule 36(1)(a) EPC for voluntarily filing a divisional application and the 24-month period of Rule 36(1)(b) EPC for filing a divisional application following a communication in which the Examining Division has made a non-unity objection, have been excluded from further processing because both periods are already of substantial length. ${ }^{69}$

\subsection{EPC further processing versus PLT continued processing}

The term "further processing" in Article 121 EPC is equivalent to the term "continued processing" as referred to in Article 11(2) PLT.

As indicated earlier (see $\ 3$ ), the relief that a PLT Contracting Party is obliged to provide under Article 11(1) and (2) PLT is restricted to time limits "fixed by the Office for an action in a procedure before the Office". Hence, the EPO in view of the PLT need not provide for further processing in respect of Convention periods. However, the EPO allows the use of the remedy of further processing for Office periods as well as for Convention periods, although there are exceptions, in particular, in relation to Convention periods (see $\$ 5.2$ ).

The EPC follows Article 11(1)(i) PLT in that when extension of an Office period is requested, such request has to be presented prior to the expiration of the period [Rule 132(2) EPC]. The EPC does not allow filing a request for extension of an Office period after the expiration of the period. As the EPC does not provide for the latter type of extension, the EPC is, in principle, obliged to provide for further processing [consequence of Article 11(2) PLT referring to Article 11(1)(ii) PLT]. However, pursuant the exception in Rule 12(5)(a)(i) PLT [Article 11(3) PLT], a PLT Contracting Party is not obliged to grant more than one instance of relief under Article 11(1) PLT (extension of time limit) or Article 11(2) PLT (continued processing), although it is permitted to do so. Hence, the EPC is not obliged, in view of the requirements under the PLT, to grant

67 "Notice from the European Patent Office dated 15 October 2009 concerning amendments to the EPC Implementing Regulations to the European Patent Convention", EPO Official Journal, 2009, p. 533.

See http://archive.epo.org/epo/pubs/ojoog/11_09/11_5339.pdf.

68 "Revision of the European Patent Convention (EPC 2000). Synoptic presentation EPC 1973/2000 - Part II: The EPC Implementing Regulations", EPO Official Journal 2007, Special Edition No. 5i comment in relation to Rule 135 EPC.

69 "Notice from the European Patent Office dated 20 August 2009 concerning amended Rule 36(1) and (2) EPC (European divisional applications) and consequential amendments to Rules 57 (a) and 135(2) EPC", EPO Official Journal, 2009, p. 481.

See http://archive.epo.org/epo/pubs/ojoog/10_09/10_4819.pdf. 
further processing after an extension of an Office period has been previously allowed. Nevertheless, the EPC provides for the extension of Office periods as well as for further processing. As explained in $\mathbb{} 5.1$, the only "period to be specified" which is ruled out from further processing in Rule 135(2) EPC is the Office period of Rule 59 EPC (deficiencies in claiming priority).

Rule 135(1) EPC prescribes that further processing under Article 121(1) EPC must be requested by payment of the prescribed fee within 2 months of the communication concerning either the failure to observe a time limit or a loss of rights; the omitted act must be completed within the period for making the request. As all documents filed after filing the European patent application must be signed [Rule 50(3) EPC], these requirements for requesting further processing are in line with Article 11(2) and (3) and with Rule 12(3)(i) and (4) PLT.

There is no explicit provision in the EPC that the non-observed period for which further processing is requested must be identified; Rule 12(3)(ii) PLT allows a PLT Contracting State to set such a requirement. However, requests should, in general, be clear and unambiguous to avoid a loss of rights. If an unspecified request for further processing is filed in a situation where it might apply to two periods, the EPO will probably invite the requestor to clarify the situation.

A request for further processing need not indicate any reasons upon which the request is based or file evidence with the Office [in line with Article 11(5) PLT]. The only requirement to be met is the payment of the fee for further processing [in line with Article 11(4) PLT]. As indicated above, the EPO requires the fee for further processing to be paid within the same period as that to which the filed request relates. The period for requesting further processing is 2 months from the notification of the loss of rights communication [in line with Article 11(1) and Rule 12(4) PLT].

Further processing under the EPC is available only for applicants, i.e. in grant proceedings and appeal proceedings after refusal of the application. This is in line with PLT requirements that a PLT Contracting Party is neither obliged to grant relief in respect of a time limit for an action before a Board of Appeal or other review body constituted in the framework of the Office [Rule 12(5)(a)(v) PLT] nor in respect of a time limit for an action in inter partes proceedings [Rule 12(5)(a)(vi) PLT]. ${ }^{70}$

As indicated above (see $\$ 4.2 .2$ ), the "period to be specified" in Rule 108(2) EPC in relation to the examination of a petition for review, is the only Office period for which the EPC does not allow an extension [cf. Rule 109 EPC]. Rule 108(2) EPC is drafted on the

70 Note that limitation and revocation proceedings [Article 105a EPC] are not inter partes proceedings. To be compliant with the PLT, the EPC should provide for further processing if the patent proprietor fails to observe a period vis-à-vis the EPO [see $\ 5$ ]. 
model of Rule 101(2) EPC which applies to appeal proceedings. ${ }^{71}$ As an appellant/applicant can request further processing when overrunning the "period to be specified" in Rule 101(2) EPC, this will also be possible when the appellant/applicant overruns the Office period in Rule 108(2) EPC.

In line with what is prescribed in Article 11(6) PLT, the EPO provides for the opportunity to make observations when a request for further processing is to be rejected. This is based on the fundamental "right to be heard" principle in the EPC [Article 113(1) EPC]. This provision is intended to ensure that no party can be taken by surprise by grounds for a decision against his application on which he did not have an opportunity to present his comments. $^{72}$

It can be concluded that the implementation of the remedy of further processing in the EPC is in line with the requirements of the PLT.

\section{Conclusion}

The goal of the Patent Law Treaty (PLT) is to streamline and harmonize formal requirements of national and regional patent Offices for the filing and processing of national and regional patent applications, the maintenance of patents and certain additional requirements related to patents or patent applications. The PLT does not establish a completely uniform procedure for all PLT Contracting Parties as a party to the PLT is free to require fewer, or more user-friendly, requirements than those prescribed in the PLT.

When the European Patent Convention (EPC) was aligned with the PLT in the EPC 2000 revision, the legislator chose for a relatively complete implementation of the requirements set in the PLT into the EPC. In addition, in many cases, the EPO allows more relief than what is prescribed in the PLT. However, the EPC is not compliant with respect to the PLT in some cases.

With respect to providing relief in respect of periods the duration of which is not fixed in the EPC but is determined by the European Patent Office (EPO), the EPC allows for an extension of such Office periods upon request (no reasoning required), provided such request is filed before the expiry of the normal period. Although not obliged by the PLT, the EPC allows the applicant, in addition, to request further processing for many Office periods. Furthermore, the EPC also allows an applicant to request further processing in respect of many periods the duration of which is fixed in the law. Again there is no obligation in the PLT to allow for further processing in respect of these so-called Convention periods.

71 "Revision of the European Patent Convention (EPC 2000). Synoptic presentation EPC 1973/2000 - Part II: The EPC Implementing Regulations", EPO Official Journal 2007, Special Edition No. 5i comment in relation to Rule 108 EPC.

72 Guidelines for Examination in the European Patent Office (April 2010), Part E, Chapter X, \$1.1. 
Although the duration of a large number of periods has been fixed in the EPC Articles and Rules, and although the remedy of further processing is frequently ruled out in respect of these periods, the number of possible remedies available to parties before the EPO is significantly beyond what is prescribed in the PLT. 


\section{Chapter VI - Periods and remedies under the EPC - Compliance of the EPC with the PLT - \\ Part II - Re-establishment of rights ${ }^{1}$}

\section{Introduction}

The Patent Law Treaty (PLT) aims at harmonizing and streamlining formal procedures relating to national and regional patent applications and maintenance of patents. In spite of the goal of harmonization, the PLT does not establish a uniform procedure for all PLT Contracting Parties by leaving many requirements optional, thereby allowing divergence in implementation between PLT Contracting Parties. ${ }^{2}$

The provisions concerning relief in respect of time limits fixed by the national Office of a PLT Contracting Party, in the form of an extension and/or continued processing, are among the important achievements of the PLT. ${ }^{3}$ The PLT also provides safeguard provisions if an applicant has failed to meet a time limit and, as a consequence, has lost his rights with respect to an application or patent unintentionally or in spite of all due care required by the circumstances. ${ }^{4}$ In addition, the PLT provides for a remedy for the loss of a priority right in two cases due to innocent non-compliance with related time limits. $^{5}$

During the so-called EPC 2000 revision of the European Patent Convention (EPC), the European Patent Organization has opted for a relatively complete implementation into the EPC of the requirements set in the PLT.

This Chapter compares the requirements in respect of the remedies of reinstatement of rights and restoration of priority right under the PLT with the remedy of re-establishment of rights under the EPC.

The requirements for relief in respect of time limits under the PLT, i.e. the extension of time limits fixed by the Office and the related remedy of continued processing, and the corresponding extension of Office periods and the remedy of further processing under the EPC are the subject of Chapter $V$ of this thesis.

1 This Chapter is an updated version of an Article: Cees Mulder: "Periods and remedies under the EPC - Compliance of the EPC with the PLT - Part II - Re-establishment of rights" accepted for publication in European Intellectual Property Review, Issue 2 (2012).

2 "Basic Features to the Patent Law Treaty" (prepared by the International Bureau) (November 2006), Item 3.

See http://www.wipo.int/patent-law/en/plt.htm.

3 Ibid., Item 38.

4 Ibid., Item 42.

5 Ibid., Item 45. 


\section{Reinstatement of rights - Article 12 and Rule 13 PLT}

Article 12 PLT obliges a PLT Contracting Party to provide for the reinstatement of rights with respect to an application or patent following failure to comply with a time limit for an action in a procedure before the Office. In contrast to Article 11 PLT, where an applicant cannot be required to state the grounds on which the request is based, such reinstatement is subject to a finding by the Office that the failure occurred in spite of all due care required by the circumstances or, at the option of the PLT Contracting Party, was unintentional. In further contrast to Article 11 PLT, Article 12 PLT is not restricted to time limits fixed by the Office, although there are some exceptions (see $\$ 2.2$ ). A PLT Contracting Party may provide for continued processing instead of reinstatement of rights under Article 12 PLT where the requirements in respect of continued processing are more favourable, from the viewpoint of applicants and patent owners, than the requirements under Article 12 and Rule 13 PLT. $^{6}$

In the introductory words of Article 12(1) PLT, the phrase "that failure has the direct consequence of causing a loss of rights with respect to an application or patent" is intended to cover situations where a failure to comply with a time limit causes a loss of rights with respect to the ability to obtain or maintain a patent. For example, where failure to comply with the time limit in respect of filing a copy of the earlier application in relation to the filing date requirements concerning a missing part of the description under Article 5(6)(b) PLT, ${ }^{7}$ has the direct consequence of the loss of the earlier filing date which, in turn, has the indirect consequence of the refusal of the application on the grounds of prior publication, a PLT Contracting Party is not obliged to provide for reinstatement of the loss of rights resulting from that refusal. ${ }^{8}$

\subsection{Request for reinstatement}

A request for reinstatement under Article 12(1) PLT should comprise the following items:

(i) The request must be filed within the prescribed time limits. The time limit for making the request for reinstatement shall be the earliest expiration date of either at least 2 months from the date of removal of the cause of failure to comply with the time limit for the action in question, or at least 12 months from the date of

6 "Explanatory Notes on the Patent Law Treaty and Regulations under the Patent Law Treaty adopted by the Diplomatic Conference on June 1, 2000", Document PT/DC/48 Prov. (November 2000), Note 12.01. Also see Article 2(1) PLT on the freedom of PLT Contracting Parties to provide for requirements which are more favourable.

See http://www.wipo.int/meetings/en/details.jsp?meeting_id=4057.

$7 C f$. Rule 2(3) and (4) PLT on the time limit and requirements in relation to the availability of the earlier application when a missing part of the description or a missing drawing is filed based on the missing part or drawing being completely contained in the earlier application.

8 "Explanatory Notes on the Patent Law Treaty and Regulations under the Patent Law Treaty adopted by the Diplomatic Conference on June 1, 2000", Document PT/DC/48 Prov. (November 2000), Note 12.02. 
expiration of the time limit for the action in question. In the case of a request for reinstatement relating to non-payment of a maintenance fee, the latter period shall not be less than 12 months from the date of expiration of the period of grace provided under Article 5 bis of the Paris Convention [Rule 13(2) PLT].

(ii) The request must state the reasons for failure to comply with the time limit. In addition, a PLT Contracting Party may require that the applicant or owner files a declaration or other evidence in support of the reasons referred to in this item within a time limit fixed by the Office [Article 13(4) PLT].

In addition, a PLT Contracting Party may require that a request be signed by the applicant or owner [Rule 13(1) PLT]; on behalf of the applicant or owner a representative may sign the request. ${ }^{9}$

An Office is obliged to reinstate the rights of the applicant or owner with respect to the application or patent concerned, if the Office finds that the failure to comply with the time limit occurred in spite of due care required by the circumstances having been taken or, at the option of the PLT Contracting Party, that any delay was unintentional [Article 13(1)(iv) PLT]. A PLT Contracting Party is permitted to charge a fee in respect of a request for reinstatement [Article 13(4) PLT].

\subsection{Exceptions}

Article 12(2) PLT lists procedures in respect of which a PLT Contracting Party is not obliged to provide for the reinstatement of rights under Article 12(1) PLT, although it is permitted to do so. ${ }^{10} \mathrm{~A}$ list of these exceptions is given in Rule 13(3) PLT:

(i) A PLT Contracting Party is not obliged under Article 12(1) PLT to grant relief in respect of a time limit for an action before a Board of Appeal or other review body constituted in the framework of the Office.

(ii) This item is intended to prevent an applicant or owner from obtaining double relief for filing a request for the extension of an Office time limit [Article 11(1) PLT] or for continued processing after failure to comply with an Office time limit [Article 11(2) $\mathrm{PLT}$ ] or for reinstatement of rights [Article 12(1) PLT]. ${ }^{11}$

(iii) A PLT Contracting Party is not obliged under Article 12(1) PLT to grant relief in respect of the time limit for correction or addition of a priority claim [Article 13(1) $\mathrm{PLT}$ ] or for requesting restoration of the right of priority [Article 13(2) or (3) PLT]. ${ }^{12}$

(iv) A PLT Contracting Party is not obliged under Article 12(1) PLT to grant relief in respect of a time limit for an action in inter partes proceedings. ${ }^{13}$

\footnotetext{
$9 \quad$ Ibid., Note R13.01.

10 Ibid., Note R13.02.

11 Ibid., Note R13.03.

12 Ibid., Note R13.03.

13 Ibid., Note R13.04.
} 


\subsection{Opportunity to make observations}

Article 12(5) PLT gives the requesting party the right to make observations on the intended refusal of a request under Article 12(1) PLT, for example, to assert that a fee in relation to a request for reinstatement of rights [Article 12(3) PLT] has been paid in time.

\section{$\mathbf{2 . 4} \quad$ Intervening rights}

The PLT and its Regulations do not regulate the rights, if any, acquired by a third party for any acts which were started, or for which effective and serious preparations were started, in good faith, during the period between the loss of rights resulting from the failure to comply with the time limit concerned and the date on which those rights are reinstated. These remain a matter for the applicable law of the PLT Contracting Party concerned. ${ }^{14}$

\section{Restoration of the priority right-Article 13 and Rule 14 PLT}

\subsection{Delayed filing of the subsequent application - Article 13(2) and Rule 14(4) and (5) PLT}

Article 13(2) PLT obliges a PLT Contracting State to provide for the restoration of the priority right where a subsequent application is filed after the expiration of the priority period, but within a time limit which may not be less than 2 months from the date on which the priority period expired [Rule 14(4)(a) PLT]. A reference to Article 15 PLT was included in Article 13(2) PLT to clarify that due account is taken of the provisions of the Paris Convention. ${ }^{15}$ The request for restoration of a priority claim may be filed after the filing of the subsequent application, provided that it accompanies the request for restoration [cf. Rule 14(5)(ii) PLT]. ${ }^{16}$

The requirements to be met in order for an Office to restore the right to priority under Article 13(2) PLT are:

(i) A request to that effect is made to the Office in accordance with the prescribed requirements. In particular, a PLT Contracting Party may require that a request be signed by the applicant [Rule 14(5)(i) PLT]. Alternatively, a representative may sign on behalf of the applicant. ${ }^{17}$

(ii) The time limit for making the request for restoration shall expire not less than 2 months from the date on which the priority period expired or the time that any technical preparations for publication of the subsequent application have been completed, whichever expires earlier [Rule 14(4)(b) PLT].

\footnotetext{
14 Ibid., Note 12.10.

15 Ibid., Note 13.05.

16 Ibid., Note 13.05.

17 Ibid., Note R14.02.
} 
(iii) The request must state the reasons for failure to comply with the priority period. The applicant may be required under Article 13(5) PLT to file a declaration or other evidence in support of the reasons for failure to comply with the priority period.

(iv) The Office finds that the failure to file the subsequent application within the priority period occurred in spite of all due care required by the circumstances having been taken or, at the option of the PLT Contracting Party, was unintentional.

A PLT Contracting Party is permitted to charge a fee in respect of a request for restoration [Article 13(4) PLT]. In addition, Article 13(6) PLT gives the requesting party the right to make observations on the intended refusal of a request under Article 13(2) PLT.

\subsection{Failure to file a copy of the earlier application - Article 13(3) and Rule 14(6) and (7) PLT}

Article 13(3) PLT obliges a PLT Contracting State to provide for the restoration where a right of priority is lost because of the failure, on the part of the Office with which the earlier application was filed to provide a copy of that application in time, to comply with the time limit applicable under Article 6(5) PLT, despite a timely request for that copy having been made. Since the time limit for filing the priority document is normally established by national legislation or under a regional treaty, but not by the Office, a remedy in this respect will not normally be available by way of extension of time limit or continued processing under Article $11 \mathrm{PLT}{ }^{18}$ The request for restoration of a priority claim may be filed after the filing of the subsequent application, provided that it accompanies the request for restoration [cf. Rule 14(5)(ii)]. ${ }^{19}$

The requirements to be met in order for an Office to restore the right to priority under Article 13(3) PLT are:

(i) A request to that effect is made to the Office in accordance with the prescribed requirements. In particular, a PLT Contracting Party may require that a request be signed by the applicant [Rule 14(6)(a)(i) PLT]. Alternatively, a representative may sign on behalf of the applicant. ${ }^{20}$

(ii) The request is filed within the time limit for filing the copy of the earlier application prescribed in the Regulations pursuant to Article 6(5) PLT. The purpose of this item is to permit an applicant who is unable to file the required copy of the earlier application within the time limit referred to in Rule 4(1) PLT (not less than 16 months from the (earliest) priority date claimed) to, instead, file a request for restoration of the priority right within that time limit. ${ }^{21}$

\footnotetext{
18 Ibid., Note 13.09 .

19 Ibid., Note 13.05.

20 Ibid., Note R14.04.

21 Ibid., Note 13.11.
} 
(iii) The Office finds that the request for the copy to be provided had been filed with the Office with which the earlier application was filed, within a time limit which expires 2 months before the expiration of the time limit in Rule 4(1) PLT [Rule 14(7) $\mathrm{PLT}$ ]. This time limit provides a legal assurance for the applicant in that, if he requests a copy of the earlier application within that time limit, he is entitled to restore his priority right in the event that the Office concerned fails to provide that copy in time for compliance with the time limit referred to in Rule 4(1)PLT. ${ }^{22}$

(iv) A copy of the earlier application is filed within a prescribed time limit. A PLT Contracting Party may require that this time limit shall be not less than 1 month from the date on which the applicant is provided with that copy by the Office with which the earlier application was filed [Rule 14(6)(b)(ii) PLT].

A PLT Contracting Party is permitted to charge a fee in respect of a request for restoration [Article 13(4) PLT]. In addition, Article 13(6) PLT gives the requesting party the right to make observations on the intended refusal of a request under Article 13(3) PLT.

\section{Re-establishment of rights under the EPC - Article 122 and Rule 136 $E P C$}

In the EPC 2000 revision, Article 122 EPC was amended to take account of the broadening of the scope of application of further processing. ${ }^{23}$ According to Article 122(2) EPC, the EPO will grant a request for re-establishment of rights, provided that the conditions of Article 122(1) EPC and the other requirements laid down in the EPC Implementing Regulations have been met [Rule 136 EPC]. In particular, the request for re-establishment must be filed within 2 months from the removal of the cause of non-compliance with the period, but at the latest within one year of expiry of the unobserved period [Rule 136(1) EPC]. What is new in the EPC 2000 is that re-establishment in the priority period [Article 87(1) EPC] has become possible (see $\$ 4 \cdot 3 \cdot 5 \cdot 1)$.

Due to the requirement of proving "all due care" in Article 122(1) EPC (see $\$ 4.3 .2$ ), the remedy of re-establishment of rights is not as straightforward and reliable as further processing. In addition, a request for re-establishment does not have suspensive effect on the proceedings [Article 122(5) EPC]. Therefore, any person may, under certain conditions, start using the invention and continue such use without payment (see $\$ 4 \cdot 3 \cdot 8)$.

22 Ibid., Note 13.12.

23 "Revision of the European Patent Convention (EPC 2000). Synoptic presentation EPC 1973/2000 -Part I: The Articles", EPO Official Journal 2007, Special Edition No. 4; comment in relation to Article 122 EPC.

See http://www.epo.org/patents/law/legal-texts/journal/2007.html. 
Article 122(3) EPC corresponds to the equivalent provision in Article 121(3) EPC concerning further processing and makes the principle underlying re-establishment of rights quite clear, i.e. that the consequences of failure to observe a period will be deemed not to have ensued where a request for re-establishment is granted.

Article 122(4) EPC provides for re-establishment to be ruled out in respect of the time limit for requesting re-establishment [this exclusion is repeated in Rule 136(3) EPC]. In addition, the EPC Implementing Regulations rule out re-establishment for other periods as well. In particular, in view of the broader scope of application of further processing, the EPO has chosen to rule out re-establishment for periods in respect of which further processing can be requested [cf. Rule 136(3) EPC]. ${ }^{24-25}$

In general, the scope of application of re-establishment of rights under the EPC 2000 has been narrowed down in view of the broadened applicability of further processing. As far as grant proceedings are concerned, re-establishment has been replaced to some extent by further processing, and applies where the priority period or the period for requesting further processing have not been observed. Moreover, any periods for which further processing is ruled out are, in principle, susceptible of re-establishment under Article 122 EPC. In addition, only patent proprietors are able to request re-establishment of rights as a legal remedy in opposition proceedings and inter partes appeal proceedings. ${ }^{26}$

\subsection{Office periods and re-establishment}

If "a period to be specified" by the EPO in grant proceedings or ex parte appeal proceedings is missed, further processing may be requested. Pursuant Rule 136(3) EPC, re-establishment of rights is ruled out for periods in respect of which further processing can be requested. This exclusion applies to all Office periods except for the "period to be specified" in Rule 59 EPC (deficiencies in the priority claim) which is the only Office period for which further processing is ruled out according to Rule 135(2) EPC. Hence, re-establishment of rights is available as a remedy when the period of Rule 59 EPC is not observed (see $\ 4 \cdot 3 \cdot 5 \cdot 2$ ).

${ }^{24}$ Ibid., comment in relation to Article 122 EPC.

25 Rule 136(3) EPC excludes those periods for which further processing can be requested because further processing is cheaper and more efficient as it does not require substantial work by either the applicant or the EPO. However, the exclusion formulated in Rule 136(3) EPC falls apart when the period for further processing has also been missed. This is not an impossible situation: it could e.g. happen that the applicant's working documents have been destroyed by fire and he has been obliged to prepare fresh ones. In such case, the EPO interprets Rule 136 EPC as excluding those periods for which further processing has been (but no longer is) possible, with the consequence that both re-establishment and further processing must now be requested.

26 "Revision of the European Patent Convention (EPC 2000). Synoptic presentation EPC 1973/2000 - Part l: The Articles", EPO Official Journal 2007, Special Edition No. 4; comment in relation to Article 122 EPC. 
Re-establishment of rights is available if the proprietor of a European patent in opposition or subsequent appeal proceedings fails to observe "a period to be specified" by the EPO. Because further processing is only possible for applicants, re-establishment is, in principle, available in these Office periods. Examples of Office periods for which the proprietor can request re-establishment are:

0 the period for correcting deficiencies in the request for limitation [Rule 94 EPC], and

O the period for amending the description or claims if the requested amendment does not constitute a limitation or if there is a clarity objection [Rule 95(2) EPC].

Re-establishment is not possible in the "period to be specified" in Rule 79(1) EPC (communication of the notice of opposition to the proprietor) because there is no "direct consequence" as specified in Article 122(1) EPC if the proprietor does not file observations or amendments. The same applies if the proprietor does not reply to an invitation pursuant Rule 81(2) EPC (examination of the opposition).

Re-establishment is also not possible in the "period to be specified" in Rule 100(2) EPC (invitation to file observations by the Board of Appeal) in pre-grant appeal proceedings, because Rule 100(3) EPC in this case provides for the deemed withdrawal of the application and further processing is not ruled out [cf. Rule 135(2) and Rule 136(3) EPC].

\subsection{Convention periods and re-establishment}

As almost half of the periods in the EPC Implementing Regulations are excluded from further processing according to Rule 135(2) EPC, the remedy of re-establishment of rights is in principle available in respect of all these periods. As the duration of all but one of these periods is fixed in the EPC, this remedy is, in particular, applicable to Convention periods.

Examples of Convention periods in the EPC for which re-establishment is possible:

- Filing a European patent application while claiming priority from an earlier application after expiry of the 12-month period of Article 87(1) EPC but within 2 months of the expiry of the priority period [Rule 136(1) EPC],

- Filing a request for further processing [Article 121 and Rule 135 EPC],

- Filing a translation of a European patent application which was filed in another language than English, French or German [Rule 6(1) EPC],

- Filing a divisional application [Rule 36(1)(a) and (b) EPC],

- Correcting deficiencies in the application documents [Rule $58 \mathrm{EPC}$ ],

- Filing a request by the patent proprietor for a decision by the Opposition Division in relation to apportionment of costs [Rule 88(3) EPC], and

- Filing a translation of the amended claims and paying the fee for publishing the amended patent specification in limitation proceedings [Rule 95(3) EPC]. 
As explained, re-establishment for periods in respect of which further processing can be requested has been ruled out [Rule 136(3) EPC]. There is one exception to this Rule which is caused by a requirement set in the Patent Cooperation Treaty (PCT) and which relates to the 31-month period for entry of an international application into the regional phase before the EPO. This period is a Convention period fixed in Rule 159(1) EPC. ${ }^{27}$ If an applicant has not performed the required acts under Rule 159(1) EPC in due time [cf. Rule 16o(1) EPC], the EPO will issue a communication that the Euro-PCT application is deemed to be withdrawn [cf. Rule 160(2) and Rule 112(1) EPC]. The applicant may within 2 months from the notification of the loss of rights communication request further processing [Article 121 and Rule 135 EPC]. Re-establishment of rights in the 31-month period of Rule 159(1) EPC is excluded because further processing is available [ $c f$. Rule 136(3) EPC]. However, the applicant, in this particular case, may, in principle, request re-establishment of rights for payment of the filing fee and, where required, for filing the translation of the Euro-PCT application into English, German or French. ${ }^{28}$ This exception is based on PCT Rule 49.6 prescribing that where an applicant failed to perform the acts referred to in PCT Article 22 within the applicable time limit, the designated Office must, upon request of the applicant, reinstate the rights of the applicant with respect to that international application. ${ }^{29}$ The delay in meeting the time limit may either be unintentional or, at the option of the designated Office, may have occurred in spite of due care required by the circumstances having been taken. The "acts referred to in PCT Article 22" relate only to the payment of the "national fee" and to the filing of a required translation, and not to the other acts to be performed under in Rule 159(1) EPC. Under the EPC a translation must be filed if the international application is not published in English, French or German [cf. Article 153(4) and Rule 159(1)(a) EPC]. In addition, the "national fee" in PCT Article 22 is the "filing fee" in Rule 159(1)(c) EPC. ${ }^{30}$

\subsection{EPC re-establishment versus PLT reinstatement and restoration}

The term "re-establishment of rights" in Article 122 EPC is equivalent to the term "reinstatement of rights" as referred to in Article 12 PLT. In contrast to Article 11 PLT, which only provides for relief in respect of time limits fixed by the Office, Article 12 PLT is not restricted to time limits fixed by the Office. Under the EPC, re-establishment of rights is, in principle, possible for Office periods as well as for Convention periods.

27 The time limits for entry into the national/regional phase are specified in PCT Article 22(1) and (3) for designated Offices and in PCT Article 39(1)(a) and (b) for elected Offices.

28 A reference to PCT Rule 49.6(d)(i) was explicitly added to Article 2(1), Item 13 of the Rules relating to Fees in relation to the fee for "reinstatement of rights".

See http://www.epo.org/patents/law/legal-texts/html/epc/2010/e/articl2.html\#2.

${ }^{29}$ Cf. PCT Rule 76.5 referring to PCT Rule 49 for procedures before elected Offices.

30 "Implementation of the Decision of the Administrative Council of 28 June 2001 on the Transitional Provisions under Article 7 of the Act revising the European Patent Convention of 29 November 2000", \$3.1. This document is an annex to EPO Official Journal 2007, p. 504. See http://archive.epo.org/epo/pubs/ojoo7/10_07/10_5047.pdf. 
The EPC also uses the term "re-establishment of rights" in Article 122 EPC for the restoration of the priority right as referred to in Article 13(2) and (3) PLT (see $\ 4 \cdot 3 \cdot 5$ ).

\subsubsection{Direct consequence}

According to Article 122(1) EPC, the remedy of re-establishment of rights is only available if the non-observance of the period has the direct consequence of causing the refusal of the European patent application or of a request, of the deeming of the application to have been withdrawn, or the revocation of the European patent, or the loss of any other right or means of redress. This wording is in line with the provision in Article 12(1) PLT that failure to comply with the time limit "has the direct consequence of causing a loss of rights with respect to an application or patent" ( $c f . \$ 2)$.

\subsubsection{Due care criterion}

As described in $\ 2$, Article 12 PLT allows a PLT Contracting State to make the reinstatement of rights subject to a finding by the Office that the failure occurred in spite of due care required by the circumstances having been taken or, at the option of the PLT Contracting Party, was unintentional. The Patent Cooperation Treaty (PCT) allows for both criteria. ${ }^{31}$ For historical reasons, the use of the "all due care" criterion was continued in the EPC 2000; the EPO does not allow the use of the more friendly "unintentional". Hence, it is necessary for the applicant or proprietor or representative, as the case may be, to supply evidence that he exercised all due care required by the circumstances and that the delay was caused by unforeseeable factors. ${ }^{32}$

The EPO also employs the "all due care" criterion where an applicant pursuant PCT Rule 49.6 requests re-establishment of rights for the acts as referred to in PCT Article 22, i.e. paying the filing fee and, where required, filing the translation of the Euro-PCT application into English, German or French (see \$4.2).

\subsubsection{Exceptions to re-establishment}

According to the wording of Article 122(1) EPC, re-establishment of rights is only available for an applicant for or a proprietor of a European patent. This is in line with the exceptions in Article 12(2) and Rule 13(3) PLT (cf. \$2.2). Pursuant Article 122(1) EPC, re-establishment of rights is excluded for opponents in respect of the period for filing the notice of appeal [Article 108 EPC]. As an exception, an opponent who has filed an appeal

${ }^{31}$ Cf. PCT Rules 26 bis.3 and 49ter. 2 A list the criteria employed by receiving Offices and designated Offices allowing restoration of the right of priority can be found on the WIPO website.

See http://www.wipo.int/pct/en/texts/restoration.html.

32 Guidelines for Examination in the European Patent Office (April 2010), Part E, Chapter VIII, \2.2.1. see http://www.epo.org/patents/law/legal-texts/guidelines.html. 
can request re-establishment of rights in respect of the period for submitting the statement setting out the grounds of appeal. ${ }^{33}$

Although not obliged by the PLT [cf. Rule 13(3)(i) PLT], the EPC also provides re-establishment of rights in respect of the period for filing a petition for review [Article 112a EPC]. However, the maximum period for requesting re-establishment in respect of the period for filing a petition for review has been abridged from the normal period of 1 year to 2 months from expiry of the 2-month periods referred to in Article $112 \mathrm{a}(4) \mathrm{EPC}$. The reason is that, in virtually all appeal cases, the unrestricted possibility of re-establishment of rights in respect of the periods under Article 112a(4) EPC would entail an additional 1-year period of uncertainty as to whether the decision of the Board of Appeal has final legal force. ${ }^{34}$ It is noted that providing reinstatement for an action before a Board of Appeal or other review body is one of the exceptions listed in Rule 13(3)(i) PLT for which a PLT Contracting Party need not provide for the reinstatement of rights.

To avoid a chaining of remedies, Article 122(4) EPC excludes the period for requesting re-establishment from re-establishment of rights. This is in line with the exceptions listed in Rule 12(5)(a)(ii) and Rule 13(3)(ii) PLT.

\subsubsection{Re-establishment in the period of further processing}

In line with the exceptions listed in Rule 13(3)(ii) PLT the EPO is not obliged to provide double relief in respect of further processing and re-establishment of rights. Hence, either further processing or re-establishment of rights may be requested if a specific period has been missed. During the grant procedure, only further processing will normally be available; re-establishment of rights only comes into play where further processing is excluded with regard to a specific period [see, in particular, Rule 135(2) $E P C]$. The limitation of the possibility of re-establishment of rights during the grant procedure is, however, offset to some extent by the fact that re-establishment of rights in respect of the period for further processing is possible. ${ }^{35}$ This means that, if further processing is available, but the applicant fails to request it in time, re-establishment of rights according to Article 122 EPC is available for the period for requesting further processing. ${ }^{36-37}$

33 Decision of the Enlarged Board of Appeal, G 1/86, EPO Official Journal, 1987, p. 447.

See http://archive.epo.org/epo/pubs/oj1987/p447_472.pdf.

34 "Revision of the European Patent Convention (EPC 2000). Synoptic presentation EPC 1973/2000 - Part II: The EPC Implementing Regulations", EPO Official Journal 2007, Special Edition No. 5i comment in relation to Rule 136 EPC.

See http://www.epo.org/patents/law/legal-texts/journal/2007.html.

35 Ibid., comment in relation to Rule 136 EPC.

${ }^{36}$ Guidelines for Examination in the European Patent Office (April 2010), Part E, Chapter VIII, \2.2.1. 


\subsubsection{Restoration of the priority right}

The EPC also uses the term "re-establishment of rights" in Article 122 EPC for the restoration of the right to priority in relation to the delayed filing of the subsequent application [Article 13(2) PLT] as well as to the failure to file a copy of the priority application [Article 13(3) PLT].

\section{4-3.5.1 Re-establishment in the priority period}

For re-establishment of the priority period under Article 87(1) EPC (see $\$ 3.1$ ), the minimum time limit fixed by Rule 14(4) PLT implementing Article 13(2) PLT has been incorporated: the period for filing such requests ends 2 months after expiry of the priority period [Rule 136(1), second sentence, EPC].$^{38}$ The normal period of 1 year for requesting re-establishment of rights does not apply here in view of the central importance of establishing the date of filing and/or priority for the valid claiming of priority. ${ }^{39}$

\subsubsection{Re-establishment in the period for filing of a copy of the priority application}

The general procedure for filing priority documents under the EPC is as follows (for each item a reference to the counterpart in the PLT is included; also see $\$ 3.2$ ).

- An applicant claiming priority while filing a European patent application must file a certified copy of the previous application within 16 months from the earliest priority date [Rule 53(1) EPC]. This provision including the certification and the 16-month period is in line with Article 6(5) and Rule 4(1) and (2)PLT.

- No copy of a priority document need be filed where the earlier application is available to the EPO [Rule 53(1) EPC]; the EPO will add the copy free of charge to the file. ${ }^{40}$ This provision is in line with Rule 4(3) PLT.

- If the priority document is not provided within the prescribed period, the EPO will invite the applicant to provide it within "a period to be specified" [Rule 59 EPC]. This period under Rule 59 EPC cannot be less than 2 months or more than 4 months [Rule 132(2) EPC]..$^{41}$ This provision including the period is in line with Article 6(7) and Rule 6(1) PLT.

37 For a discussion of the remedy of re-establishment of rights in respect of time limits fixed by the Office as prescribed in Article 11(2) PLT see: Cees Mulder: "Periods and remedies under the EPC - Compliance of the EPC with the PLT. Part I - Extension of periods and further processing", European Intellectual Property Review, 2012. An updated version of this article is included in Chapter $V$ of this thesis.

38 "Revision of the European Patent Convention (EPC 2000). Synoptic presentation EPC 1973/2000 - Part I: The Articles", EPO Official Journal 2007, Special Edition No. 4; comment in relation to Article 122 EPC.

39 "Revision of the European Patent Convention (EPC 2000). Synoptic presentation EPC 1973/2000 - Part II: The EPC Implementing Regulations", EPO Official Journal 2007, Special Edition No. 5i comment in relation to Rule 136 EPC.

$4^{0}$ Guidelines for Examination in the European Patent Office (April 2010), Part A, Chapter III, \$ 6.7.

${ }^{41}$ Ibid., Part A, Chapter III, $\$ 16.2$. 
- Because the period in Rule 59 EPC is an Office period, the applicant may request extension of the period if a request is filed before expiry of the normal period [Rule 132(2) EPC]. Allowing the extension of the period is in line with Article 11(1)(i) PLT.

- If the priority document is not filed in due time, the right to priority is lost for the European patent application [Article 90(5) EPC]. This provision is in line with Article 6(8) PLT.

- Further processing in the period of Rule 59 EPC is ruled out in Rule 135(2) EPC. Not allowing further processing after allowing an extension of the period in Rule 59 EPC is in line with the exceptions listed in Rule 12(5)(a)(i) PLT.

- Re-establishment of rights is, in principle, possible in respect of the late filing of the priority application. The provision of re-establishment of rights is in line with the requirement in Article 13(3)(iii) and Rule 14(7) PLT. The 1-year period of Rule 136(1) is to be calculated from the expiry of the unobserved period, i.e. from the expiry of the 16-month period of Rule 53(1) EPC. ${ }^{22}$

The EPO did not implement the optional requirement in Rule 14(6)(b)(ii) PLT that the copy of the priority application must be filed with the EPO within a period of at least 1 month from the date on which the applicant is provided with that copy by the Office with which the earlier application was filed.

If the priority document was not available during the international phase, the EPO will invite the applicant pursuant Rule 163(2) EPC to furnish the file number and the copy of the priority document by expiry of the 31-month period of Rule 159(1) EPC. The 2-month period specified in the invitation is a Convention period. If the file number or copy is not filed in due time, the right to priority is lost for the Euro-PCT application [Rule 163(2) $E P C]$. In this situation, further processing is available.

\subsubsection{Renewal fees}

As described in $\$ 3.3$, the EPO is not obliged to provide for the extension of, or further processing in respect of, a period fixed by the EPO for the payment of renewal fees [ $c f$. Rule 12(5)(a)(iii) PLT]. However, a "period of grace" for the payment of such fee must be provided in view of Article 5bis(1) Paris Convention. In line with the latter requirement, Rule 51(2) EPC allows for an additional 6-month period to pay the renewal fee, provided an additional fee is also paid within that period. As explained in $\$ 5.2$, further processing is excluded in the period of Rule 51(2) EPC [cf. Rule 135(2) EPC]. Hence, re-establishment of rights is, in principle, possible if the applicant fails to observe the additional period under Rule 51(2) EPC. In view of the minimum time limit specified in Rule 13(2)(ii) PLT, the 6-month additional period under Rule 51(2) EPC is not to be deducted from the period of 1 year for requesting re-establishment of rights (as was the case under the

42 Decision of the Legal Board of Appeal, J 1/80, EPO Official Journal, 1980, p. 289.

See http://legal.european-patent-office.org/dg3/biblio/j800001ep1.htm. 
EPC 1973). The 1-year period of Rule 136(1) EPC begins on expiry of the 6-month period for payment of renewal fees, instead of on the date when payment falls due. ${ }^{43}$

\subsubsection{Opportunity to make observations}

In line with what is prescribed in Article 12(5) PLT (see $\ 2.3$ ) and Article 13(6) PLT (see $\int 3.1$ and 3.2), the EPO provides for the opportunity to make observations when a request for re-establishment of rights is rejected, for example, to assert that the fee for re-establishment of rights [Rule 136(1) EPC, last sentence] has been paid in time. This opportunity to make observations is enshrined in the "right to be heard" principle in the EPC [Article 113(1) EPC].

\subsubsection{Intervening rights}

As described in $\ 2.4$, the PLT does not regulate any intervening rights in relation to a request for re-establishment of rights. Nevertheless, the EPC provides under Article 122(5) EPC, that the right to continued use without payment is provided for any person who has in good faith used or made effective and serious preparations for using an invention in the period between the loss of rights and the publication of the re-establishment of such rights. The requirement of good faith guarantees that no rights can be acquired in an abusive way.

\section{Conclusion}

The goal of the Patent Law Treaty (PLT) is to streamline and harmonize formal requirements of national and regional patent Offices for the filing and processing of national and regional patent applications, the maintenance of patents and certain additional requirements related to patents or patent applications. The PLT does not establish a completely uniform procedure for all PLT Contracting Parties as a party to the $\mathrm{PLT}$ is free to require fewer, or more user-friendly, requirements than those prescribed in the PLT.

When the European Patent Convention (EPC) was aligned with the PLT in the EPC 2000 revision, the legislator chose for a relatively complete implementation of the requirements set in the PLT into the EPC. In addition, in many cases, the EPO allows more relief than what is prescribed in the PLT. However, the EPC is not compliant with respect to the PLT in some cases.

With respect to the remedy "reinstatement of rights" as prescribed by the PLT, the EPC provides for re-establishment of rights in situations where an applicant or proprietor has failed to observe a period and, as a consequence, has lost his rights with respect to a European patent application or European patent. As allowed by the PLT, the EPO uses

43 "Revision of the European Patent Convention (EPC 2000). Synoptic presentation EPC 1973/2000 - Part II: The EPC Implementing Regulations", EPO Official Journal 2007, Special Edition No. 5; comment in relation to Rule 136 EPC. 
the principle of "all due care required by the circumstances", which is to be proven by the applicant or proprietor upon requesting re-establishment of rights.

Further in line with the provisions of the PLT, the EPC also provides for a remedy for the loss of a priority right in relation to the delayed filing of the subsequent application as well as in relation to the failure to file a copy of the priority application in due time.

Although the duration of a large number of periods has been fixed in the EPC Articles and Rules, and although the remedy of further processing is frequently ruled out in respect of these periods, the number of possible remedies available to parties before the EPO is significantly beyond what is prescribed in the PLT. 
This page was left blank intentionally. 


\section{Chapter VII - Time limits and remedies under the PCT - Compliance of the PCT with the PLT? ${ }^{1}$}

\section{Introduction}

The Patent Law Treaty $^{2}$ (PLT) aims at harmonizing and streamlining formal procedures relating to national and regional patent applications and maintenance of patents. The PLT regulates the maximum set of requirements that an Office of a PLT Contracting Party may apply: the Office may not require any other formal requirements in respect of the matters dealt with by the PLT. In other words, the PLT does not establish a completely uniform procedure for all PLT Contracting Parties, but a Contracting Party is free to require fewer, or more user-friendly, requirements than those prescribed in the PLT. $^{3}$

The provisions concerning relief in respect of time limits fixed by the Office, in the form of an extension and/or continued processing, belong to the important achievements of the PLT. ${ }^{4}$ The PLT also provides safeguard provisions if an applicant or owner has failed to meet a time limit and, as a consequence, has lost his rights with respect to an application or patent unintentionally or in spite of all due care required by the circumstances. ${ }^{5}$ In addition, the PLT provides for a remedy for the loss of a priority right in two cases due to innocent non-compliance with the related time limits. ${ }^{6}$

Both the Patent Law Treaty (PLT) and the Patent Cooperation Treaty (PCT) are international treaties on patent law. The PCT cannot become a "Contracting Party" to the PLT.7 So there is, ex lege, no reason for the PCT to comply with the requirements set by the PLT, e.g. with respect to the accordance of a date of filing or relief in respect of time limits. A main feature of the PLT is that it provides standardized formality requirements for patent applications which are filed with a national or regional patent Office. Instead of defining these requirements again or differently in the PLT, it was decided, wherever appropriate, to incorporate by reference the provisions of the PCT and

1 This Chapter has been submitted for publication in The WIPO Journal: Cees Mulder: "Time limits and remedies under the PCT - Compliance of the PCT with the PLT?"

2 The Patent Law Treaty was adopted on June 1, 2000 at a Diplomatic Conference in Geneva; the Treaty entered into force on April 28, 2005. See WIPO Publication No. 258(E).

See http://www.wipo.int/treaties/en/ip/plt/.

3 "Basic Features to the Patent Law Treaty" (prepared by the International Bureau) (November 2006), Item 3.

See http://www.wipo.int/patent-law/en/plt.htm.

4 Ibid., Item 38.

5 Ibid., Item 42.

6 Ibid., Item 45.

7 See Article 20 PLT. 
its Regulations into the PLT. The main reason for this is that the PCT already regulates in detail the formality requirements with respect to international applications. ${ }^{8}$

In view of the close relationship between the PLT and the PCT, it seems "strange" that the PCT does not "comply" with the basic requirements of the PLT. The PCT was modified in view of the adoption of the PLT, but only to satisfy in a simplified way a number of requirements of national law which have to be met when at a later date the application enters the national/regional phase of processing. Later on, attempts were undertaken to improve alignment of the PCT with the PLT, but this was largely impossible because amendment of the Articles of the PCT was regarded necessary. This Chapter compares the requirements in respect of relief in respect of time limits and the available remedies under the PLT with their counterparts in the PCT.

$\int 2$ discusses the relationship between the Patent Cooperation Treaty and the Patent Law Treaty. The requirements for relief in respect of time limits under the PLT, i.e. the extension of time limits fixed by the Office and the related remedy of continued processing, are dealt with in $\$ 3$. The duration of time limits including the possible extension of these time limits under the PCT are the subject of $\$ 4$. The remedy of reinstatement of rights under the PLT and its counterpart in the PCT are discussed in $\ 5$ and 6 , respectively. The remedy of restoration of the priority right under the PLT is dealt with in $\$ 7$; its counterpart in the PCT is the subject of $\$ 8$. In $\$ 9$, a conclusion and recommendations are offered.

\section{Relationship between the PCT and the PLT}

The relationship between the Patent Law Treaty (PLT) and the Patent Cooperation Treaty (PCT) is a complicated one. Although the PLT is applicable primarily to national and regional patent applications, it incorporates by reference the standards prescribed by the PCT as to the form and contents of international applications. ${ }^{9}$ These procedural and administrative requirements include the form and contents of national and regional patent applications, the type of translations of documents and the evidence which an applicant may be required to provide to an Office in the course of processing his application.

The PLT also applies to international (PCT) applications as regards:

(i) the time limits for national phase entry [PCT Article 22 and 39(1); Article 3(1)(b)(i) $\mathrm{PLT}]$; and

(ii) the entire processing of the international application before any designated/elected Office after national phase entry [Article 3(1)(b)(ii) PLT].

8 "Basic Features to the Patent Law Treaty" (prepared by the International Bureau) (November 2006), Items 13-19.

9 See Article 6(1) PLT. 
In addition, certain provisions appear duplicative, i.e., are to be found in both the PLT and the PCT. One example is Article 3(1)(b)(i) PLT and PCT Rule 49.6 in relation to provisions for the reinstatement of rights after failure to perform the acts referred to in $\mathrm{PCT}$ Article 22. ${ }^{10}$ Another example is Article 3(1)(b)(ii) PLT and PCT Rule 49 ter.2 in relation to provisions for restoration of the right of priority by the designated Office. ${ }^{11}$ There is a simple explanation for this: because it would take years, if not decades, for all PCT Member States to ratify the PLT, the easiest way to "advance" the entry into force of some PLT provisions was to include similar (if not identical) provisions in the PCT. Of course, options for making reservations had to be incorporated in the PCT stating that if these provisions are not compatible with the national law applied by the designated Office, they would not apply in respect of that Office for as long as they continue not to be compatible with that law [see PCT Rule 49.6(f) and Rule 49ter.2(h)]. In this manner a much faster application of these provisions was achieved as would have been the case otherwise.

In view of the adoption of the PLT, the PCT Regulations were amended in the spirit of the PLT, enabling applicants, when filing an international application, to satisfy in a simplified manner a number of requirements of national law which have to be met when the international application, at a later date, enters the national/regional phase before the national/regional Office of a PLT Contracting Party.

An in-depth discussion on the relationship between the PLT and the PCT and the alignment of the PCT with the PLT with respect to the requirements for the accordance of a filing date including the submission of missing parts and elements was published elsewhere. ${ }^{12}$ In addition, a detailed comparison between the requirements in respect of relief regarding time limits and the remedy of continued processing as well as the remedies of reinstatement of rights and restoration of the priority right under the PLT with their counterparts in the European Patent Convention was published elsewhere..$^{13-14}$

10 "Changes related to the Patent Law Treaty (PLT): missed time limit for entering the national phase" (prepared by the International Bureau), Working Group on Reform of the PCT, Document PCT/R/WG/2/4 (March 2002), Item 8.

See http://www.wipo.int/meetings/en/details.jsp?meeting_id=4554.

11 "Restoration of the Right of Priority " (prepared by the International Bureau), Document PCT/R/WG/6/1 (March 2004).

See http://www.wipo.int/meetings/en/details.jsp?meeting_id $=5622$.

12 Cees Mulder: "Filing date requirements under the PCT - Alignment with the PLT?", The WIPO Journal, Volume 2, Issue 2 (2011), pp. 173-195. An updated version of this article is included in Chapter IV of this thesis.

See http://www.wipo.int/about-wipo/en/wipo_journal/.

13 Cees Mulder: "Periods and remedies under the EPC - Compliance of the EPC with the PLT. Part I - Extension of periods and further processing", European Intellectual Property Review, 2012. An updated version of this article is included in Chapter $V$ of this thesis.

${ }^{14}$ Cees Mulder: "Periods and remedies under the EPC - Compliance of the EPC with the PLT. Part II - Re-establishment of rights", European Intellectual Property Review, 2011. An updated version of this article is included in Chapter VI of this thesis. 


\section{Relief in respect of time limits - Article 11 and Rule 12 PLT}

Article 11 of the PLT governs the requirements for the extension of time limits and for continued processing of an application or a patent. This Article obliges a PLT Contracting Party to provide relief in respect of time limits. Such relief may be in the form of an extension of the time limit [Article 11(1) PLT] and/or continued processing and, if necessary, reinstatement of the rights of the applicant or owner [Article 11(2) PLT]. ${ }^{15-16}$ The relief in the time limit is subject only to the filing of a request in accordance with the requirements of Article 11(1) or (2) and Rule 12 PLT, and, where applicable, to the payment of a fee [Article 11(4) PLT]. Accordingly, the applicant or owner concerned may not be required to state the grounds on which the request is based or to file evidence with the Office [Article 11(5) PLT]. ${ }^{17}$ In particular, a PLT Contracting Party is not permitted to make the grant of relief under Article 11 PLT conditional on a finding of due care or unintentionality by the Office (= authority of the PLT Contracting Party entrusted with the granting of patents). ${ }^{18}$

The relief a PLT Contracting Party is obliged to provide under Article 11(1) and (2) PLT is restricted to time limits "fixed by the Office for an action in a procedure before the Office" ${ }^{19}$ It is for each PLT Contracting Party to decide which time limits are fixed by the Office. It follows that Article 11 PLT does not apply to time limits that are not fixed by the Office, in particular, time limits established by national legislation or under a treaty providing for the grant of regional patents. ${ }^{20}$

15 "Explanatory Notes on the Patent Law Treaty and Regulations under the Patent Law Treaty adopted by the Diplomatic Conference on June 1, 2000" (prepared by the International Bureau), Diplomatic Conference for the Adoption of the PLT, Document PT/DC/48 Prov. (November 2000), Note 11.01.

See http://www.wipo.int/meetings/en/details.jsp?meeting_id=4057.

16 There is no explanation in the Explanatory Notes on the PLT about the meaning of the wording "if necessary" in relation to the applicability of the remedy reinstatement of rights. However, in the Summary Minutes of the Main Committee I (prepared by the International Bureau) ( $14^{\text {th }}$ session; published in Records of the Diplomatic Conference for the Adoption of the Patent Law (Geneva, 2000); WIPO Publication 327E, p. 414, Item 1226), it was explained by a representative of the WIPO: "The reason for using the word 'if necessary' in respect of continued processing was that under different national systems providing for continued processing, some considered that the rights had been lost upon the expiration of the time limit and others consider those rights only to be lost upon the expiration of the period for requesting continued processing. Therefore, in some cases, rights would have to be reinstated and in other cases the rights would not have to be reinstated and there would simply be continued processing."

17 "Explanatory Notes on the Patent Law Treaty and Regulations under the Patent Law Treaty adopted by the Diplomatic Conference on June 1, 2000" (prepared by the International Bureau), Diplomatic Conference for the Adoption of the PLT, Document PT/DC/48 Prov. (November 2000), Note 11.08.

18 Ibid., Note 11.01.

19 Ibid., Note 11.02.

20 Ibid., Note 11.02. 


\subsection{Extension of time limits}

Article 11(1) PLT obliges a PLT Contracting Party to provide for relief in the form of the extension of a time limit fixed by the Office. A PLT Contracting Party may either require that the request for extension be filed before the expiration of that time limit [Article 11(1)(i) PLT] or that the request be filed after that expiration but within a prescribed time limit [Article 11(1)(ii) and Rule 12(2)(b) PLT]. ${ }^{21}$ A PLT Contracting Party may, in principle, provide for both types of relief under Article 11(1)(i) and (ii) PLT. The requirements in respect of the request, the period of the extension, and the time limit for filing a request referred to in Article 11(1)(ii) PLT are prescribed in Rule 12(1) and (2) $\mathrm{PLT}^{22}$

Article 11(1) PLT does not oblige a PLT Contracting Party to provide for the extension of a time limit fixed by the Office under both Article 11(1)(i) and (ii) PLT. However, a PLT Contracting Party that does not provide for extension after expiration of the time limit [Article 11(1)(ii) PLT] is obliged to provide for continued processing under Article 11(2) PLT in respect of these time limits. ${ }^{23}$

Requirements for a request for extension are given in Rule 12(1) PLT. In particular, a PLT Contracting Party may require that the request under Article 11(1) PLT be signed by the applicant or owner [Rule 12(1)(a)(i) PLT]; a representative may sign on behalf of the applicant or owner. ${ }^{24}$

\subsection{Continued processing}

Article 11(2) PLT obliges a PLT Contracting Party to provide for relief in the form of continued processing, after the applicant or owner has failed to comply with a time limit fixed by the Office, where that Contracting Party does not provide for the extension of time limits after the expiration of the time limits [Article 11(1)(ii) PLT]. ${ }^{25}$ The effect of such continued processing is that the Office continues with the procedure concerned as if that time limit had not been missed.

Requirements for a request for continued processing are given in Article 11(2)(i) and Rule 12(3) PLT. The time limit for filing the request for continued processing must at least be 2 months after a notification by the Office that a time limit was not complied with [Article 11(2)(ii) and Rule 12(4) PLT].

21 Ibid., Note 11.03. The time limit to request extension must be at least 2 months from the date of expiration of the unextended time limit [Rule 12(2)(b) PLT].

22 Ibid., Note 11.03: A Contracting Party may, under Rule 12(1)(b) PLT, require that all requirements for the extension of the time limit are complied with at the same time as the request under Article 11(1)(ii) PLT is filed.

23 Ibid., Note 11.04.

24 Ibid., Note R12.01.

25 Ibid., Note 11.05. 


\subsection{Exceptions}

Article 11(3) and Rule 12(5)(a) PLT set out a list of the "exceptional" procedures in respect of which a PLT Contracting Party is not obliged to provide for the extension of a time limit fixed by the Office [Article 11(1) PLT] or for continued processing after failure to comply with a time limit fixed by the Office [Article 11(2) PLT], although it is permitted to do so. ${ }^{26}$

\subsection{Opportunity to make observations}

Article 11(6) PLT gives the requesting party the right to make observations on the intended refusal of a request under Article 11(1) or (2) PLT, for example, to assert that a fee in relation to a request for continued processing [Article 11(4) PLT] has been paid in time. The term "refusal" is meant also to cover sanctions which are of equivalent effect to refusal of the request to extent a time limit, such as the request being treated as abandoned or withdrawn. ${ }^{27}$

\section{Relief in respect of time limits under the PCT}

According to PCT Article 47(1), the details for computing time limits are governed by the Regulations under the PCT. PCT Rule 79 defines the calendar in which dates are expressed and PCT Rule 80 explains how to calculate time limits and establishes dates of documents. In particular, PCT Rule 80.5 provides for the automatic extension of time limits if a period during which a document or fee must be reach a national Office or intergovernmental organisation expires on a day that the Office or organisation is not open for the public or ordinary mail is not delivered there.

\subsection{Time limits to be specified by an Office or Authority under the PCT}

The PCT contains a number of time limits the duration of which is to be specified by the Office or Authority. There are no such time limits in the PCT Articles. Examples of time limits "to be fixed" in the Regulations under the PCT are: ${ }^{28}$

- The time limit to furnish a sequence listing in electronic or paper form complying with the standard in the Administrative Instructions and to pay the late furnishing

26 Ibid., Note R12.02.

27 Ibid., Note 11.09.

28 The Regulations under the PCT in the version as in force since July 1, 2011. 
fee is "fixed in the invitation" by the International Searching Authority [PCT Rule 13 ter.1(a) and (b)]. ${ }^{29}$

- The invitation from the International Searching Authority to submit a correction of the disclosure of the sequence listing in the description [РCT Rule 13ter.1(f) referring to PCT Rule 5.2.(b)]. There is no time limit mentioned in relation to this invitation; it is up to the International Searching Authority to specify the time limit. ${ }^{30}$

- Several time limits in relation to international preliminary examination:

○ The time limit "fixed in the invitation" from the International Preliminary Examining Authority to submit amendments in relation to the filing of the demand for preliminary Examination [PCT Rule 6o.1(g)]. There is no guidance provided in this Rule on the normal duration. ${ }^{31}$

o The time limit in the notification in relation to the written opinion issued by the International Preliminary Examining Authority inviting the applicant to submit a written reply and, where appropriate, amendments [PCT Rule 66.2(c)]. ${ }^{32}$

- The time limit "fixed in the invitation" to file a letter identifying the international application or a signature in relation to any paper submitted by the applicant in the course of the international procedure, other than the international application itself, must be "reasonable in the circumstances". The time limit shall not be less than 10 days and not more than 1 month from the mailing of the invitation [PCT Rule 92.1(b)]. Usually, the Office will give 1 month, but there could be

${ }^{29}$ It is interesting to observe that PCT Rule 13 ter.1(a) and (b) do not include the usual phrase "reasonable under the circumstances" for the duration of the time limit. The tight time frame for the International Searching Authority to establish the international search report and the fact that, if the applicant does not submit the sequence listing in electronic form within the time limit set in the invitation, the International Searching Authority can disregard the claims relating to the sequence listing, will most probably be a strong incentive for the International Searching Authority to not readily extend the time period which they had fixed in the invitation. A time frame of one month can be expected. This provision was introduced based on a suggestion by the European Patent Office in its capacity of International Searching Authority and it is probably that Office that relies on it the most.

30 In PCT Rule 13ter.1(f) it is mentioned: "Rule 26.4 shall apply mutatis mutandis to any correction offered by the applicant." From this it seems reasonable to assume that also the time frame of PCT Rule 26.2 should be applied. However, it would seem difficult to find arguments against an International Searching Authority that were to give only 1 month in the invitation. Since this issue probably has less impact on the international search, it would seem more likely that an International Searching Authority would be willing to grant an extension than in the context of PCT Rule 13ter.1(a) and (b).

31 The minimum duration would be to at least allow a 1-month time limit for submitting the missing amendments. Since PCT Rule 6o.1(g) does not exclude it, an extension could be granted but it would be left to the discretion of the International Preliminary Examining Authority.

32 See $\$ 4.2 .1$ for the duration and extension of the time limit fixed in the notification under PCT Rule 66.2(c). 
circumstances, e.g. just before international publication, where Offices could justify only granting a short time limit. ${ }^{33}$

- Where the applicant fails to furnish the original of a required document, the national Office or intergovernmental organization concerned may invite the applicant to furnish the original within a time limit of 14 days [PCT Rule 92.4(d)] or within a time limit which is "reasonable under the circumstances" and which is "fixed in the invitation" [PCT Rule 92.4(e)(ii)]. ${ }^{34} \mathrm{~A}$ "reasonable" minimum duration of the time limit under PCT Rule 92.4 (d)would be 1 month.

If no duration of the time limit is specified in a PCT Rule but the Rule specifies that the duration should be "reasonable under the circumstances" giving the applicant a time limit with a duration of less than one month is, generally, not regarded as "reasonable". A first step to improve the situation for the applicant would be to add to all PCT Rules where no specific duration of the time limit is mentioned an indication that the duration should be "reasonable under the circumstances" and to specify in the PCT Applicant's Guide or the PCT Administrative Instructions that the "reasonable" duration should be at least 1 month. However, uncertainty for the applicant could largely be diminished if in the PCT Rules the phrase "reasonable under the circumstances" were deleted and replaced by specifying a minimum a duration of at least 1 month. This minimum duration should also be introduced in all PCT Rules where no time limit is specified and the phrase is not included. Where possible the minimum duration of time limits under the PCT should be set to be 2 months thereby improving the alignment of the PCT with the requirements under the PLT (also see the discussion in $\$ 4.3$ ).

\subsubsection{Extension of Office time limits}

In principle, any time limit which can be fixed by the competent Authority is also extendable. It is, however, a discretionary decision of the Authority concerned whether they wish to grant an extension and what procedure the applicant should follow. Some Authorities prefer the applicant not to file a separate request for extension but to submit whatever needs to be submitted while asking for an extension. ${ }^{35}$ The formulation in Article 11(1) PLT uses the wording (italics added): "A Contracting Party may provide for the extension ... of a time limit fixed by the Office for an action or a procedure before the

33 It is uncertain whether an extension of the time limit would be allowed. From the wording of PCT Rule 92.1(b), it would seem that the omission is only consider healed if the missing letter and/or signature are furnished within the time limit fixed in the invitation. One could interpret this narrowly and see no room for extension. However, in practice, many Offices including the International Bureau regularly grant extensions unless there is a particular reason why an extension would not be acceptable (e.g. imminent international publication).

34 National Offices and intergovernmental organizations are encouraged to use PCT Rule 92.4(e) rather than Rule 92.4 (d) which is much less flexible.

35 Data on the possible extension of time limits granted by the Authorities are not available. In a particular case, the applicant should contact the International Searching Authority of other Authority concerned and check whether an extension of the time limit is available. 
Office ..." So from the PLT perspective it is not compulsory to provide for an extension of Office time limits. ${ }^{36}$ However, by making the extension discretionary on the Authority concerned leaves the applicant in an uncertain position. To improve the situation for the applicant it is advisable in all PCT Rules involving a time limit, to specify at least a minimum duration and to mention that the time limit can be extended upon request. Wherever possible, the (minimum) duration should be 2 months from the date of the notification; this would be compliant with the duration of time limits for notification as specified in Rule 6(1) PLT implementing Article 6(7) PLT.

\subsection{Convention time limits}

A "Convention time limit" is defined as a time limit of which the duration is fixed in the PCT Articles or the Regulations. ${ }^{37}$ Examples of Convention time limits in the PCT Articles are:

○ The 18-month time limit for publishing the international application [PCT Article 21(1)(a)].

- The 30-month time limit for entry before a designated Office [PCT Article 22(1)] or elected Office [PCT Article 39(1)(a)].

Examples of Convention time limits in the Regulations under the PCT are:

- The 1-month time limit for furnishing a translation for the purpose of international search [PCT Rule 12.3].

O The 1-month time limit for paying the transmittal fee [PCT Rule 14.1(c)], the international filing fee [PCT Rule 15.3] and the search fee [PCT Rule 16.1(f)] including the 1-month time limit for late paying the fees upon invitation from the receiving Office [PCT Rule 16bis.1].

- The 16-month time limit for furnishing a certified copy of the priority document [PCT Rule 17.1(a)].

o The 2-month time limits for filing corrections in relation to the accordance of the international filing date including the filing of missing parts and/or missing elements [PCT Rule 20.7(a)].

- The 1-month time limit for payment of the additional fees (non-unity objection) [PCT Rule 40.1(ii); Rule 68.2(iii) and (iv)] and, where applicable, the protest fee [PCT Rule 40.1(iii) and Rule 68.2(v)].

0 The 1-month time limit for paying the supplementary search handling fee [PCT Rule 45bis.2(c)] and the supplementary search fee [PCT Rule 45bis.3(c)].

${ }^{36}$ However, Article 11(2)PLT prescribes: "Where an applicant or owner has failed to comply with a time limit fixed by the Office of a Contracting Party for an action in a procedure before the Office ..., and that Contracting Party does not provide for extension of a time limit under paragraph (1)(ii), the Contracting Party shall provide for continued processing ..." And as is described in $\$ 4.4$ there is no provision for continued processing under the PCT.

37 The more commonly used term "Convention time limit" is employed instead of "Treaty time limit". 
O The 3-month or 22-month time limit for filing the demand for preliminary examination [PCT Rule 54bis.1(a)].

- The 1-month or 22-month time limit for paying the handling fee [PCT Rule 57.3(a)] and the preliminary examination fee [PCT Rule 58.1(b)] including the 1-month time limit for late paying the fees upon invitation from the International Preliminary Examining Authority [PCT Rule 58bis.1].

\subsubsection{Extension of Convention time limits}

Apart from the automatic extension of time limits [PCT Rule 80.5], there is a number of time limits of which the duration is fixed in the PCT, which may be extended. The two time limits in the PCT Articles which may be extended are: $:^{38-39}$

- The 30-month time limit for entry into the national phase before a designated Office may be extended by a Contracting State to expire later [PCT Article 22(1) and (3); PCT Rule 50.1].

- The 30-month time limit for entry into the national phase before an elected Office may be extended by a Contracting State to expire later [PCT Article 39(1)(a) and (b); PCT Rule 77.1].

Examples of Convention time limits which may be extended according to a provision in the Regulations under the PCT are:

- The 2-month time limit for correcting defects after filing the international application under PCT Article 14(1) (e.g. missing: signature, indications applicant, title or abstract) may be extended by the receiving Office "at any time before a decision is taken" [PCT Rule 26.2; also see $\$$ 4.3.2]. The receiving Office may extend the time limit ex officio or at the request of the applicant at any time before a decision is taken. ${ }^{40}$

o The 2-month time limit for paying the fee for requesting restoration of the right of priority before the receiving Office may be extended, at the option of the receiving Office, for a period of up to 2 months from the expiration of the applicable time limit [PCT Rule 26bis.3(d)]..$^{41}$

- The time limit fixed in the notification in relation to the written opinion issued by the International Preliminary Examining Authority under PCT Rule 66.2(a) must be

${ }^{8}$ Note that the PCT only mentions that the national law of a PCT Contracting State may provide for time limits for entry into the national/regional phase expiring later than the 30 months. A list of time limits for entering the national/regional phase under PCT Chapters I and II can be found at: http://www.wipo.int/pct/en/texts/time_limits.html.

39 Note that the Article 3(1)(b)(i) PLT does apply directly to these time limits (see the discussion in $\ 2$ ).

40 PCT Applicant's Guide - International Phase, Item 6.037. See http://www.wipo.int/pct/en/appguide/index.jsp.

${ }^{41}$ Ibid., Item 5.063. 
"reasonable under the circumstances": normally it must be answered within 2 months after the date of notification. It may not be shorter than 1 month after the said date. The time limit must be at least 2 months after the date of notification where the international search report is transmitted at the same time as the notification. The time limit may not be more than 3 months after the date of notification [PCT Rule 66.2(d)]. ${ }^{42}$ In addition, the time limit for replying to the notification "may be extended if the applicant so requests before its expiration" [PCT Rule 66.2(e)]. ${ }^{43}$

- Where a period starts on the date of a notification, that period may be extended if the notification was actually mailed on a later date or was received more than 7 days after the date it bears [PCT Rule 8o.6]. ${ }^{44}$

\subsubsection{Convention time limits which may not be extended}

There are also Convention time limits where the PCT Applicant's Guide specifies that these time limits may not be extended. Examples of such time limits are:

- The 1-month time limit fixed by the receiving Office for the payment of missing or underpaid fees (transmittal fee, international filing fee, search fee) under PCT Rule 16 bis may not be extended. ${ }^{45}$

O The time limits fixed by the receiving Office [PCT Rule 20.7(a)] for the correction of defects under PCT Article 11 (international filing date) or PCT Article 14(2) (missing drawings) may not be extended. ${ }^{46}$

- The request for requesting a supplementary international search must be filed prior to the expiration of 19 months from the priority date [PCT Rule 45bis.1(a)]. If the request is received after the expiration of this time limit, it will be considered not to have been submitted and "there are no provisions to extend this time limit". ${ }^{47}$

- The 1-month time limit fixed by the International Preliminary Examining Authority for the payment of missing or underpaid fees (handling fee and preliminary examination fee) under PCT Rule 58 bis may not be extended..$^{48}$

For some of the above time limits which have a fixed duration and which may not be extended, the PCT offers some flexibility: the applicant may still perform the act after expiration of the time limit if it is performed before the Office or Authority takes the next step. Such a next step may either be an invitation to comply with the provision or the

42 PCT Rule 66.2(d) is "over-dimensioned" despite this Rule is practically never used because International Preliminary Examining Authorities are not obliged to issue a "second" written opinion [see PCT Rule 66.1bis in combination with Rule 66.4].

43 Note that the extension allowed in PCT Rule 66.2(e) is the only extension of a time limit in the PCT, as far as the author is aware, that complies with Article 11(1)(i) PLT.

44 PCT Applicant's Guide - International Phase, Item 11.062.

45 Ibid., Item 6.037; also see Items 5.193 and 5.195.

46 Ibid., Item 6.037; also see Item 6.025.

47 Ibid., Item 8.005.

48 Ibid., Item 10.047. 
issuance of a declaration that the applicant did not comply with the time limit. This flexibility applies, in particular, to the acts in relation to the filing of the international application and the demand for preliminary examination:

- The (non-extendable) time limit for paying the transmittal fee, the international filing fee and the search fee [PCT Rule 14.1(c), Rule 15.3 and Rule 16.1(f), respectively] is 1 month (see $\$ 4.2$ ). If the applicant does not pay these fees in due time, the receiving Office will invite the applicant to pay them together with a late payment fee [PCT Rule 16bis.1(a)]. However, any payment received by the receiving Office before that Office sends this invitation is considered to have been received before the expiration of the 1-month time limit [PCT Rule 16bis.1(d)]. In addition, the (non-extendable) time limit to pay the missing fees together with the late payment fee is 1 month from the invitation of the receiving Office [PCT Rule 16bis.1(a)]. However, the sanction of non-compliance does not ensue if the applicant pays the fees before the receiving Office makes the applicable declaration under PCT Article 14(3) (international application considered to be withdrawn) [PCT Rule 16bis.1(e)].

- According to PCT Rule 20.7(a), the (non-extendable) time limits for filing corrections in relation to the accordance of the international filing date including the filing of missing parts and/or missing elements are 2 months (see $\$ 4.2$ ). However, where a correction under PCT Article 11(2) or a notice under PCT Rule 20.6(a) confirming the incorporation by reference of an element referred to in PCT Article 11(1)(iii)(d) or (e) is received by the receiving Office after the expiration of the applicable time limit but before that Office sends a notification to the applicant that his application will not be treated as an international application [PCT Rule 20.4(i)], that correction or notice is considered to have been received within that time limit [PCT Rule 20.7(b)].

- The (non-extendable) time limit for paying the handling fee and the preliminary examination fee [PCT Rule 57.3(a) and Rule 58.1(b), respectively] is 1 month (see $\$ 4.2$ ). If the applicant does not pay these fees in due time, the International Preliminary Examining Authority will invite the applicant to pay them together with a late payment fee [PCT Rule 58bis.2]. However, any payment received by the Authority before it sends this invitation is considered to have been received before the expiration of the 1-month time limit [PCT Rule 58bis.1(c)].

In addition, the (non-extendable) time limit to pay the missing fees together with the late payment fee is 1 month from the invitation of the Authority [PCT Rule 58bis.1(a)]. However, the sanction of non-compliance does not ensue if the applicant pays the fees before the Authority makes the applicable declaration under PCT R.58bis.1(b) (demand considered not to have been submitted). 
- Several time limits during international preliminary examination may be extended by the International Preliminary Examining Authority "at any time before a decision is taken". In particular, this applies to: ${ }^{49}$

O The invitation to furnish a translation of the international application [PCT

Rule 55.2(c)],

o The invitation to furnish a translation of the amendments or the accompanying letter [PCT Rule 55.3(c)],

o The invitation to correct deficiencies in the demand [PCT Rule 60.1(a)].

An alternative manner to add flexibility to the system can be found in PCT Rule 17.1 in relation to the furnishing of the priority document:

- The time limit for furnishing the certified copy of the priority document is 16 months [PCT Rule 17.1(a)]. However, any copy of the priority document which is received by the International Bureau after the expiration of 16-month time limit is considered to have been received on the last day of that time limit if it reaches it before the date of international publication of the international application [PCT Rule 17.1(a)].

In addition, a designated Office may not disregard the priority claim before giving the applicant an opportunity to furnish the priority document within a time limit which shall be reasonable under the circumstances [PCT Rule 17.1(c)]..$^{50}$

\subsection{Duration and extension of PCT time limits - Influence of the PLT - Discussion}

The PLT specifies time limits for response in respect of notifications sent to the applicant or to correct deficiencies by the applicant of his own motion in the event of non compliance with certain requirements [see, e.g., Article 5(3) and (5), 6(7) and (8), 7(5) and 8(7) PLT]. In most cases, the duration of these time limits is set in the PLT Regulations to be "not less than two months" from the date of the notification or from the date the requirement was missed [see, e.g., Rule 2(1), (2), (3) and (5)(b)(i), Rule (4), Rule 6(1), Rule 7(5), Rule 11(1), Rule 12(4), Rule 15(6) and (7)(b)(i) PLT]. ${ }^{51}$

At the first session of the Working Group on Reform of the PCT held in Geneva in November 2001, proposals were presented to amend the Regulations under the PCT so

49 PCT Applicant's Guide - International Phase, Items 9.010, 10.046 and 10.066.

50 An example of a provision implemented by a designated Office pursuant PCT Rule 17.1(c) can be found in the European Patent Convention (EPC): where the European Patent Office acting as designated or elected Office finds out that the file number of the priority application or the copy thereof have not been filed in the international phase, the applicant will be invited to furnish these missing items within a time limit of 2 months [Article 153 and Rule 163(2) EPC].

51 The only time limits which are shorter than 2 months can be found indirectly in Rule 6(3) PLT in relation to the time limits for the payment of fees in respect of filing the application where for the minimum duration reference is made to the time limit for paying the international filing fee under the PCT. The latter time limit is specified to be 1 month in PCT Rule 15.3. 
as to align the requirements of the PCT with those of the PLT. With respect to the issue of "time limits", it was stated that "extension of time limits and reinstatement of rights" should be included..$^{52}$ Advanced proposals prepared by the International Bureau "to align the PCT with the PLT in respect of time limits" were contained in the Annexes of the document. ${ }^{53}$ However, in the Summary of the first session of the Working Group, a reluctance to accept these proposals could be perceived..$^{54}$ It was remarked that "certain features of the PCT system differed from national and regional patent systems, and those differences needed to be borne in mind". ${ }^{55}$ With respect to time limits it was realized that "there are certain time constraints peculiar to the PCT, such as the time limit for establishing the international search report". ${ }^{56}$ More general it was remarked that "while some provisions of the PLT could be implemented readily by changing the PCT Regulations, others would require changing the Articles of the Treaty itself" ${ }^{57}$ As a next step, priority was given by the Working Group to "those matters which would result in the greatest and most immediate practical benefits for users, having regard also to the degree of complexity involved and to workload implications for Offices and Authorities". ${ }^{58}$ With respect to time limits, this included giving priority to "provisions for restoration of the priority right in certain circumstances" (see $\$ 8.1$ ) 59 and "relief when time limits were missed, especially the time limit for entering the national phase" (see \$6). ${ }^{60}$

In preparation for the second session of the Working Group on Reform of the PCT, the International Bureau prepared a document in relation to "possible further PLT-related changes". ${ }^{61}$ The document recapitulated that Article 11 PLT obliges a PLT Contracting

52 "Changes related to the Patent Law Treaty (PLT): Contents of the International Application; Language of the International Application and Translations; Right of Priority and Priority Claims; Time Limits" (prepared by the International Bureau), Document PCT/R/WG/1/5 (October 2001), Item 1.

See http://www.wipo.int/meetings/en/details.jsp?meeting id=4446.

53 Ibid., Item 14 and Annexes.

54 "Summary of the session" - "Changes Related to the PLT" (prepared by the Chair), Document PCT/R/WG/1/9 (November 2002), Item 21.

See http://www.wipo.int/meetings/en/details.jsp?meeting_id=4446.

55 Ibid., Item 21(ii).

${ }^{5}$ Ibid., Item 21(ii).

57 Ibid., Item 21(iii).

$5^{8}$ Ibid., Item 21(v).

59 Eventually, this resulted in the adoption of PCT Rule 26bis.3 [April 1, 2007]: restoration of right of priority by the receiving Office.

60 Eventually, this resulted in the adoption of PCT Rule 49.6 [January 1, 2003]: reinstatement of rights after failure to perform the acts for entry into the national phase before the designated Office. Also see PCT Rule 49ter.

61 "Changes related to the Patent Law Treaty (PLT): Other PLT-Related Changes" (prepared by the International Bureau), Working Group on Reform of the PCT, Document PCT/R/WG/2/6 (March 2002), Items 11 and 12.

See http://www.wipo.int/meetings/en/details.jsp?meeting_id=4554. 
Party to provide relief in respect of time limits in the form of extension of that time limit after the expiration of that time limit [PLT Article 11(1)(ii)] and/or continued processing [PLT Article 11(2)]. In addition, a PLT Contracting Party may, but is not obliged to, provide for the extension of a time limit before it has expired. In addition, the document summarized that Article 12 PLT obliges a PLT Contracting Party to provide for the reinstatement of rights for failure to comply with a time limit for an action in a procedure for an action before the Office. In contrast to Article 11 PLT, Article 12 PLT is not restricted to time limits fixed by the Office. It therefore would apply to any time limit established by national law, under a treaty providing for the grant of regional patents, or under the PCT or its Regulations. In the document the International Bureau suggested that any further proposals to align PCT requirements with Articles 11 and 12 PLT would not be presented to the Working Group until a future session. ${ }^{62}$ Although this issue appears to be a matter of "relatively high priority", it requires "further consideration". ${ }^{63}$ In particular, the inclusion into the PCT Regulations of general provisions providing for the extension (by not less than 2 months) of time limits fixed by the Office for an action in a procedure before the Office [cf. Article $11 \mathrm{PLT}$ ] was regarded inherently problematic noting that the proper functioning of the PCT system relies to a great extent on actions taking place in a very limited time and within strict deadlines. ${ }^{64}$ It was emphasized that there are reasons for certain time limits as they are and that there is no room for stretching these time limits. Examples mentioned in the document were: ${ }^{65}$

- The time limit for furnishing sequence listings in electronic form [PCT Rule 13ter.1],

- The time limit for correcting formality defects in the international application [PCT Rule 26.2], ${ }^{66}$

- The time limit to correct defects in the demand or later elections [PCT Rules 60.1 and 60.2]. ${ }^{67}$

It was concluded that many time limits fixed by the Office under the PCT are already subject to the possibility of extension, albeit the granting of such an extension is in some cases discretionary for the Office. $^{68}$

62 Ibid., Item 13.

63 Ibid., Item 13.

${ }^{64}$ Ibid., Item 13.

65 Ibid., Item 13.

66 Nevertheless on April 1, 2007, the time limit specified in PCT Rule 26.2 was amended from: "The time limit referred to in Article 14(1)(b) shall be reasonable under the circumstances and shall be fixed in each case by the receiving Office. It shall not be less than one month from the date of the invitation to correct." into "The time limit referred to in Rule 26.1 shall be two months from the date of the invitation to correct."

${ }_{67}$ On January 1, 2004 PCT Rule 60.2 was deleted in view of the introduction of the automatic election of all designated States upon filing the demand [cf. current PCT Rule 53.7].

68 "Changes related to the Patent Law Treaty (PLT): Other PLT-Related Changes" (prepared by the International Bureau), Working Group on Reform of the PCT, Document PCT/R/WG/2/6 (March 2002), Item 13. 
In relation to invitations to comply with certain time limits and to make observations, it was recapitulated by the International Bureau that, under the PLT, where one or more requirements in respect of the form or contents of an application are not complied with, the Office is obliged to notify the applicant, giving the opportunity to comply with any such requirement and to make observations within a time limit of not less than 2 months from the date of the notification [see Article 6(7) and Rule 6(1) PLT]. ${ }^{69}$ It was noted that, under the $\mathrm{PCT}$, the provisions that apply depend on which requirement has not been complied with. In some cases, there is no express provision for the applicant to be given an opportunity to comply. In the case of lack of unity of invention, express provision is made for the applicant to submit observations and these must be in the form of a "reasoned statement" [PCT Rules 40.2(c) and 68.3(c)]. Also, many of the time limits for complying with $\mathrm{PCT}$ requirements are shorter than the corresponding time limits applicable under the $\mathrm{PLT}^{70}$ As a conclusion, the International Bureau suggested that any proposals to align other provisions under the PCT (an extensive list of provisions in the PCT Regulations was included) would not be presented to the Working Group until a future session, as this does not appear to be a high priority. ${ }^{71}$

Eventually, the PCT Assembly adopted a number of amendments to the PCT Regulations to improve the alignment of the provisions in the PCT with the PLT. The majority of these changes was implemented when the Regulations under the PCT were amended on April 1, 2007..$^{72}$ The important issues which were introduced or amended were: ${ }^{73}$

- Accordance of the international filing date [PCT Rule 20] including the incorporation by reference of missing parts or missing elements in the international application [PCT Rule 20.5 and 20.6 and Rule 4.18].

- Correction of defects in priority claims [PCT Rule 26bis.2].

- Restoration of the right of priority by the receiving Office [PCT Rule 26bis.3] and by the designated Office [PCT Rule 49ter].

- Rectification of obvious mistakes [PCT Rule 91].

Some remarks in relation to these and related issues are given in the following paragraphs. A discussion of the subject restoration of the right to priority under the PCT can be found in $\$ 8.1$. It is noted that already on January 1, 2003 PCT Rule 49.6 was

69 Ibid., Item 21.

70 lbid., Item 22.

71 Ibid., Item 23.

72 Already earlier amendments to the PCT Regulations were adopted in relation to the PLT. For example, on March 1, 2003, PCT Rule 49.6 was introduced in relation to the reinstatement of rights after failure to comply with the requirements for national phase entry within the time limits under PCT Articles 22 and 39(1). See Chapter 6 of this article.

73 "Proposed Amendments of the PCT Regulations; Corrections relating to Document PCT/A/34/2" (prepared by the International Bureau), PCT Assembly, $34^{\text {th }}$ ( $15^{\text {th }}$ ordinary) session, Document PCT/A/34/2 Rev. (September 2005), Annex II.

See http://www.wipo.int/meetings/en/details.jsp?meeting_id=goo6. 
introduced relating to the reinstatement of rights after failure to comply with the requirements for national/regional phase entry within the time limits under PCT Articles 22 and 39(1) (see \$6).

There is no general provision in the PCT Articles or its Regulations that time limits may be extended upon request of the applicant of by the Office or Authority acting under the $\mathrm{PCT} .{ }^{74}$ As has been described hereinabove, there is a number of time limits in the PCT Rules for which the Rule itself allows for extension. For most of the PCT Rules for which the PCT Applicant's Guide rules out extension of the time limit, there is in many cases an extension of the time limit as long as the Office or Authority involved has not yet taken the next step. In particular, the last option adds uncertainty for the applicant.

\section{4-3.1 Accordance of the international filing date}

Despite the tight time schedule of the PCT, a number of time limits in the above new/amended PCT Rules has been stretched to 2 months in line with the minimum time limit of "not less than 2 months from the date of the notification" specified in Rule 2(1) PLT implementing Article 5(3) PLT. In particular, all time limits in relation to the accordance of the international filing date including any corrections thereof as well as the filing of missing parts or missing elements whether upon invitation from the receiving Office or of own volition of the applicant, have become 2 months since April 1, 2007 [PCT Rule 20.7]. Hence, with respect to time limits, PCT Rule 20 is in line with the PLT. In addition, PCT Rule 20.3(a) and 20.5(a) allow an applicant to make observations where the requirements for the accordance of the international filing date are not, or appear not to be, fulfilled by the applicant. This provision is in line with Article 5(3) PLT.

A discussion with respect to the requirements for the accordance of a date of filing (e.g. with respect to the compulsory presence of "a part which on the face of it appears to be a claim or claims) including the filing of an application by reference to a previously filed application and the submission of missing parts and elements was published elsewhere. ${ }^{75}$

\subsubsection{Correction of deficiencies after filing the international application}

Also on April 1, 2007 the time limit of Rule 26.2 PCT in relation to an invitation from the receiving Office to correct deficiencies in the international application [PCT Article 14(1)(b)] was fixed to become 2 months from the date of the invitation. In addition, some flexibility was added to Rule 26.2 PCT by specifying that the 2-month

74 For example, the European Patent Convention provides for extension of time limits specified by the European Patent Office if the request is filed before expiry of the period [Rule 132(2) EPC; $c f$. Article 11(1)(i) PLT].

75 Cees Mulder: "Filing date requirements under the PCT - Alignment with the PLT?", The WIPO Journal, Volume 2, Issue 2 (2011), pp. 173-195. An updated version of this article is included in Chapter IV of this thesis. 
time limit may be extended by the receiving Office "at any time before a decision is taken" [PCT Rule 26.2]. ${ }^{76}$

Furthermore, PCT Rule 26.1 as amended allows an applicant to make observations with respect to the invitation to correct deficiencies. This provision is in line with Article 5(3) PLT.

\subsubsection{Correction or addition of priority claims}

PCT Rule 26bis.1 allowing an applicant to correct or add a priority claim, on or after the filing date, to an application which could have claimed the priority of an earlier application but did not do so, was already introduced in the PCT on July 1, 1998, i.e. well before the adoption of the PLT. It is noted that Article 13(1) PLT and Rule 14(2) and (3) PLT are modelled after PCT Rule 26bis.1. ${ }^{77}$

\subsubsection{Defects in priority claims}

An amended version of PCT Rule 26bis. 2 in relation to the correction of defects in priority claims entered into force on April 1, 2007. The amended Rule addresses the situation where a request for restoration of the priority has been filed by the applicant. In particular, the receiving Office is obliged to invite the applicant to correct the priority claim where the international application has an international filing date which is later than the date on which the priority period expired. If the international filing date is within 2 months from the date on which the priority period expired, the applicant will be notified of the possibility of submitting a request for the restoration of the right of priority in accordance with PCT Rule 26 bis. $3 .{ }^{78}$ This brings PCT Rule 26 bis. 2 in line with Article 13(2) PLT.

\subsubsection{Rectification of obvious mistakes}

On April 1, 2007 a completely redrafted version of PCT Rule 91 in relation to the rectification of obvious mistakes in the international application and other documents entered into force. The provisions in the previous version of PCT Rule 91 entitled

76 PCT Applicant's Guide - International Phase, Item 6.037 adds more flexibility: "The receiving Office may extend the time limit ex officio or at the request of the applicant at any time-even after the time limit fixed in the invitation has expired - before a decision is taken on whether the applicant has submitted the correction within the time limit and whether or not the international application so corrected is to be considered withdrawn."

77 "Explanatory Notes on the Patent Law Treaty and Regulations under the Patent Law Treaty adopted by the Diplomatic Conference on June 1, 2000" (prepared by the International Bureau), Diplomatic Conference for the Adoption of the PLT, Document PT/DC/48 Prov. (November 2000), Note 13.01.

78 "Restoration of the Right of Priority "(prepared by the International Bureau), Document PCT/R/WG/6/1 (March 2004), Annex I, p. 4.

See http://www.wipo.int/meetings/en/details.jsp?meeting_id=5622. 
"Obvious errors in documents" were open to different interpretations and had given rise to inconsistent decisions. ${ }^{79}$

The time limit to rectify obvious mistakes is 26 months from the priority date [PCT Rule 91.2]; there is no provision to extend this time limit. Originally a time limit of 28 months from the priority date was proposed but this was regarded too late to enable completion of all the necessary actions before the end of the international phase, in particular, republication of the international application where the rectification of an obvious mistake had been authorized. ${ }^{80}$

\subsection{No continued processing under the PCT}

That are no provisions under the PCT for continued processing if the applicant has failed to comply with a time limit fixed by the Office, as provided for under Article 11(2) PLT. ${ }^{81}$

In the Working Group on Reform of the PCT the matter of introducing "continued processing" into the PCT was rarely discussed. The issue of "continued processing" was mentioned in its second session under the heading "Possible further PLT-related Changes" while recapitulating Article 11 PLT (also see $\$ 4.3$ ). ${ }^{82}$ The International Bureau suggested in the document that any further proposals to align PCT requirements with Articles 11 and 12 PLT would not be presented to the Working Group until a future session. ${ }^{83}$

In the Committee on Reform of the PCT the issue of "simplifying and streamlining the current PCT system and conforming it to the PLT" was widely discussed and supported by the majority of the Delegations, however, without addressing the issue of "continued processing" ${ }^{84}$ There are provisions in the PCT which to a limited extent circumvent the lack of continued processing in the PCT. The most commonly applied provision is allowing an Office or Authority to extend the time limit in an invitation to correct certain defects "at any time before a decision is taken". The best known example is in PCT Rule 26.2 giving the receiving Office a discretionary power to extend the 2-month time limit for correcting defects after filing the international application under PCT

79 "Rectification of Obvious Mistakes " (prepared by the International Bureau), Document PCT/R/WG/7/6 (April 2005), Item 1.

See http://www.wipo.int/meetings/en/details.jsp?meeting_id=7129.

8o Ibid., Item 19.

81 "Study regarding the Interface between the Draft Patent Law Treaty and the Patent Cooperation Treaty" (prepared by Leslie Lewis and Busso Bartels), Document SCP/2_St (March 1999), Item 11.01.

See http://www.wipo.int/scp/en/meetings/session_2/index.htm.

82 "Changes related to the Patent Law Treaty (PLT): Other PLT-Related Changes" (prepared by the International Bureau), Working Group on Reform of the PCT, Document PCT/R/WG/2/6 (March 2002), Items 11 and 12.

83 Ibid., Item 13.

84 "Report" (adopted by the Committee), Committee on Reform of the Patent Cooperation Treaty, Document PCT/R/1/26 (May 2001).

See http://www.wipo.int/meetings/en/details.jsp?meeting_id=4306. 
Article 14(1). Other examples of such "ex Officio" extensions are listed in $\$ 4 \cdot 2.1$. Another type of relief in respect of time limits can be found in PCT Rule 66.4 bis requiring the International Preliminary Examining Authority to take into account amendments, arguments and rectifications of obvious mistakes received before the examiner begins to draw up a written opinion or the international preliminary examination report. ${ }^{85}$

The Working Group on Reform of the PCT, as far as known, has never taken a formal decision that the remedy of continued processing would not be implemented into the $P C T$. As already mentioned in $\$ 4 \cdot 3$, the inclusion into the PCT Regulations of general provisions providing for the extension of time limits was already regarded as problematic in view of a proper functioning of the PCT system. Adding an additional time limit for allowing the applicant to benefit from continued processing would be a bridge too far for the tight timeframe of the PCT. However, measures could have been considered by the Working Group and implemented into the PCT Regulations to dispose of the discretionary possibility of extending certain time limits (such as in PCT Rule 26.2) and replace this by a system which is more reliable to the applicant.

It should be noted that the PCT provides for another manner to overcome delays in meeting time limits. A failure to meet a time limit in the proceedings before the receiving Office or a delay in furnishing documents to that Office can be excused under PCT Article $48 .{ }^{86}$ In particular, the PCT prescribes that any Contracting State must, as far as that State is concerned, excuse, for reasons allowed by its national law, any delay in meeting any time limit [PCT Article 48(2)(a)]. Moreover, any Contracting State may, as far as it is concerned, excuse for other reasons any delay in meeting any time limit [PCT Article 48(2)(b)]. In addition, a delay in meeting a time limit which has resulted in the international application being considered withdrawn, during either the international phase or the national phase, may be excused under certain circumstances. ${ }^{87}$ The excusing of a delay is to be understood as any decision which has the effect of the international application being treated as if the time limit had not been exceeded. However, the excusing of a delay cannot be requested during the international phase. It may be granted only in the national phase (for delays in both the international phase and the national phase) by each designated Office individually, and only as far as that Office is concerned. In principle, all national provisions related to the excusing of delays can be applied to international applications in the same manner and under the same conditions as they are to national applications. Examples of such provisions are listed in PCT

85 "Study regarding the Interface between the Draft Patent Law Treaty and the Patent Cooperation Treaty" (prepared by Leslie Lewis and Busso Bartels), Document SCP/2_St (March 1999), Item 11.01.

86 PCT Applicant's Guide - International Phase, Item 6.056.

87 PCT Applicant's Guide - National Phase, Item 6.022. See http://www.wipo.int/pct/en/appguide/index.jsp. 
Rule 82 bis. 2 and are those that allow for the reinstatement of rights, restoration, restitutio in integrum or further processing. ${ }^{88}$

The excuse of any time limit by an Office in respect of an international application as provided in PCT Article 48(2)(a) and in PCT Rules 82.2 and 82 bis.1 can be regarded as an relief in respect of time limits under the provisions of Article $11 \mathrm{PLT}^{89}$

\section{Reinstatement of rights - Article 12 and Rule 13 PLT}

Article 12 PLT obliges a PLT Contracting Party to provide for the reinstatement of rights with respect to an application or patent following failure to comply with a time limit for an action in a procedure before the Office. In contrast to Article 11 PLT, such reinstatement is subject to a finding by the Office that the failure occurred in spite of all due care required by the circumstances or, at the option of the PLT Contracting Party, was unintentional. In further contrast to Article 11 PLT, Article 12 PLT is not restricted to time limits fixed by the Office, although there are some exceptions. A PLT Contracting Party may provide for continued processing instead of reinstatement of rights under Article 12 PLT where the requirements in respect of continued processing are more favourable, from the viewpoint of applicants and owners, than the requirements under Article 12 and Rule 13 PLT. ${ }^{90}$

In the introductory words of Article 12(1) PLT, the phrase "that failure has the direct consequence of causing a loss of rights with respect to an application or patent" is intended to cover situations where a failure to comply with time limit causes a loss of rights with respect to the ability to obtain or maintain a patent. For example, where failure to comply with the time limit in respect of filing a copy of the earlier application in relation to the filing date requirements concerning a missing part of the description under Article 5(6)(b) PLT, ${ }^{91}$ has the direct consequence of the loss of the earlier filing date which, in turn, has the indirect consequence of the refusal of the application on the

88 By way of example, the European Patent Convention (EPC) has a provision for "further processing" [Article 121 and Rule 135 EPC] and re-establishment of rights [Article 122 and Rule 136 EPC].

89 "Study regarding the Interface between the Draft Patent Law Treaty and the Patent Cooperation Treaty" (prepared by Leslie Lewis and Busso Bartels), Document SCP/2_St (March 1999), Item 11.01.

90 "Explanatory Notes on the Patent Law Treaty and Regulations under the Patent Law Treaty adopted by the Diplomatic Conference on June 1, 2000", Document PT/DC/48 Prov. (November 2000), Note 12.01. Also see Article 2(1) PLT on the freedom of PLT Contracting Parties to provide for requirements which are more favourable.

${ }_{91}$ Cf. Rule 2(3) and (4) PLT on the time limit and requirements in relation to the availability of the earlier application when a missing part of the description or a missing drawing is filed based on the missing part or drawing being completely contained in the earlier application. 
grounds of prior publication, a PLT Contracting Party is not obliged to provide for reinstatement of the loss of rights resulting from that refusal..$^{22}$

\subsection{Request for reinstatement}

A request for reinstatement under Article 12(1) PLT should comprise the following items:

(i) A PLT Contracting Party may require that a request be signed by the applicant or owner [Rule 13(1) PLT]. In addition, a representative may sign on behalf of the applicant or owner. ${ }^{93}$

(ii) The request must be filed within the prescribed time limits. The time limit for making the request for reinstatement shall be the earlier to expire of either at least 2 months from the date of removal of the cause of failure to comply with the time limit for the action in question, or at least 12 months from the date of expiration of the time limit for the action in question [Rule 13(2) PLT].

(iii) The request must state the reasons for failure to comply with the time limit.

A PLT Contracting Party is permitted to charge a fee in respect of a request for reinstatement [Article 13(4) PLT]. In addition, a PLT Contracting Party may require that the applicant or owner files a declaration or other evidence in support of the reasons referred to in this item within a time limit fixed by the Office [Article 13(5) PLT].

An Office is obliged to reinstate the rights of the applicant or owner with respect to the application or patent concerned, if the Office finds that the failure to comply with the time limit occurred in spite of due care required by the circumstances having been taken or, at the option of the PLT Contracting Party, that any delay was unintentional [Article 13(1)(iv) PLT]. ${ }^{94}$

\subsection{Exceptions}

Article 12(2) PLT lists procedures in respect of which a PLT Contracting Party is not obliged to provide for the reinstatement of rights under Article 12(1) PLT, although it is permitted to do so. ${ }^{95} \mathrm{~A}$ list of these exceptions is given in Rule 13(3) PLT.

\subsection{Opportunity to make observations}

Article 12(5) PLT gives the requesting party the right to make observations on the intended refusal of a request under Article 12(1) PLT, for example, to assert that a fee in relation to a request for reinstatement of rights [Article 12(3) PLT] has been paid in time.

92 "Explanatory Notes on the Patent Law Treaty and Regulations under the Patent Law Treaty adopted by the Diplomatic Conference on June 1, 2000", Document PT/DC/48 Prov. (November 2000), Note 12.02.

93 Ibid., Note R13.01.

94 Ibid., Note 12.06.

95 Ibid., Note R13.02. 


\section{Reinstatement of rights under the PCT}

In the second session of the Working Group on Reform of the PCT the matter of introducing "reinstatement of rights" was discussed in order to promote alignment of the PCT with the requirements in Article 12 PLT in relation to the recognition that Article 3(1)(b)(i) PLT expressly provides that the provisions of the PLT and the Regulations under the PLT are applicable, subject to the provisions of the PCT, to international applications in respect of the time limits applicable under PCT Articles 22 and 39(1) in the Office of the PLT Contracting Party. ${ }^{96}$ As a result PCT Rule 49.6 was introduced in relation to the reinstatement of rights after failure to comply with the requirements for national/regional phase entry within the time limits under PCT Articles 22 and 39(1). PCT Rule 49.6 was introduced into the PCT already on January 1, 2003. ${ }^{97}$ Upon adopting the Rule, the option was created for designated Offices to declare that their national law is not compatible with that provision. Unfortunately, there are, at present, still 11 States which such a reservation. ${ }^{98-99}$

The provision of PCT Rule 49.6 is the only instance where the PCT provides for reinstatement of rights. The Working Group on Reform of the PCT, as far as known, has never discussed introducing the remedy of reinstatement of rights for missing any other time limit in the PCT.

\section{Restoration of the priority right-Article 13 and Rule 14 PLT}

\subsection{Delayed filing of the subsequent application - Article 13(2) and Rule 14(4) and (5) PLT}

Article 13(2) PLT obliges a PLT Contracting State to provide for the restoration of the priority right where a subsequent application is filed after the expiration of the priority period, but within a time limit which may not be less than 2 months from the date on which the priority period expires [Rule 14(4)(a) PLT]. A reference to Article 15 PLT was

96 "Changes related to the Patent Law Treaty (PLT): missed time limit for entering the national phase" (prepared by the International Bureau), Working Group on Reform of the PCT, Document PCT/R/WG/2/4 (March 2002), Item 1.

See http://www.wipo.int/meetings/en/details.jsp?meeting_id=4554.

97 "Report" (adopted by the Assembly), PCT Assembly, $31^{\text {st }}$ ( $18^{\text {th }}$ ordinary) session, Document PCT/A/31/10 (October 2002), Annex IV.

See http://www.wipo.int/meetings/en/doc_details.jsp?doc_id=15101.

98 Designated Offices with a reservation under PCT Rule 49.6 are (status on October 10, 2011): $C A, C N, D E, I N, J P, K R, L V, M X, N Z, P H$ and PL.

See http://www.wipo.int/pct/en/texts/reservations/res incomp.html.

99 The European Patent Office as designated Office has withdrawn its reservation with respect to PCT Rule 49.6 [ $c f$. Rule 76.5 for the EPO as elected Office] effective the entry into force of the EPC 2000 on December 13, 2007. Information on the consequences of this withdrawal can be found in "How to get a European patent - Guide for applicants - Part 2 - PCT procedure before the EPO - "Euro-PCT" ( ${ }^{\text {th }}$ edition, April 2008), Items 335, 351 and 361. See http://www.epo.org/service-support/publications/procedure/guide-2.html. 
included in Article 13(2) PLT to clarify that due account is taken of the provisions of the Paris Convention. ${ }^{100}$ The request for restoration of a priority claim may be filed after the filing of the subsequent application, provided that it accompanies the request for restoration [cf. Rule 14(5)(ii) PLT]. ${ }^{101}$

The requirements for an Office to restore the right to priority under Article 13(2) PLT are:

(i) A request to that effect is made to the Office in accordance with the prescribed requirements. In particular, a PLT Contracting Party may require that a request be signed by the applicant [Rule 14(5)(i) PLT]. In addition, a representative may sign on behalf of the applicant. ${ }^{102}$

(ii) The time limit for making the request for restoration shall not expire less than 2 months from the date on which the priority period expired or the time that any technical preparations for publication of the subsequent application have been completed, whichever expires earlier [Rule 14(4)(b) PLT].

(iii) The request must state the reasons for failure to comply with the priority period. The applicant may be required under Article 13(5) PLT to file a declaration or other evidence in support of the reasons for failure to comply with the priority period.

(iv) The Office finds that the failure to file the subsequent application within the priority period occurred in spite of all due care required by the circumstances having been taken or, at the option of the PLT Contracting Party, was unintentional.

A PLT Contracting Party is permitted to charge a fee in respect of a request for restoration [Article 13(4) PLT]. In addition, Article 13(6) PLT gives the requesting party the right to make observations on the intended refusal of a request under Article 13(2) PLT.

\subsection{Failure to file a copy of the earlier application - Article 13(3) and Rule 14(6) and (7) PLT}

Article 13(3) PLT obliges a PLT Contracting State to provide for the restoration where a right of priority is lost because of the failure, on the part of the Office with which the earlier application was filed to provide a copy of that application in time, to comply with the time limit applicable under Article 6(5) PLT, despite a timely request for that copy having been made. Since this time limit is normally established by national legislation or under a regional treaty, but not by the Office, a remedy in this respect will not normally be available by way of extension of time limit or continued processing under Article 11

\footnotetext{
100 "Explanatory Notes on the Patent Law Treaty and Regulations under the Patent Law Treaty adopted by the Diplomatic Conference on June 1, 2000", Document PT/DC/48 Prov. (November 2000), Note 13.05.

101 Ibid., Note 13.05.

102 Ibid., Note R14.02.
} 
$\mathrm{PLT} .{ }^{103}$ The request for restoration of a priority claim may be filed after the filing of the subsequent application, provided that it accompanies the request for restoration [cf. Rule 14(6)(a)(ii)]. ${ }^{104}$

The requirements for an Office to restore the right to priority under Article 13(3) PLT are:

(i) A request to that effect is made to the Office in accordance with the prescribed requirements. In particular, a PLT Contracting Party may require that a request be signed by the applicant [Rule 14(6)(a)(i) PLT]. In addition, a representative may sign on behalf of the applicant. ${ }^{105}$

(ii) The request is filed within the time limit for filing the copy of the earlier application prescribed in the Regulations pursuant to Article 6(5) PLT. The purpose of this item is to permit an applicant who is unable to file the required copy of the earlier application within the time limit referred to in Rule 4(1) PLT (not less than 16 months from the (earliest) priority date claimed) to, instead, file a request for restoration of the priority right within that time limit. ${ }^{106}$

(iii) The Office finds that the request for the copy to be provided had been filed with the Office with which the earlier application was filed, within a time limit which expires 2 months before the expiration of the time limit in Rule 4(1) PLT [Rule 14(7) $\mathrm{PLT}]$. This time limit provides a legal assurance for the applicant in that, if he requests a copy of the earlier application within that time limit, he is entitled to restore his priority right in the event that the Office concerned fails to provide that copy in time for compliance with the time limit referred to in Rule 4(1)PLT. ${ }^{107}$

(iv) A copy of the earlier application is filed within a prescribed time limit. A PLT Contracting Party may require that this time limit shall be not less than 1 month from the date on which the applicant is provided with that copy by the Office with which the earlier application was filed [Rule 14(6)(b)(ii) PLT].

A PLT Contracting Party is permitted to charge a fee in respect of a request for restoration [Article 13(4) PLT]. In addition, Article 13(6) PLT gives the requesting party the right to make observations on the intended refusal of a request under Article 13(3) PLT.

\section{Restoration of the right of priority under the PCT}

In the Study regarding the interface between the PLT and the PCT prepared in relation to the meeting of the Standing Committee on the Law of Patents (April 1999), it was observed that there is no provision under the PCT corresponding to the provision in Article 13(2) PLT for the restoration of the right of priority where the failure to file the

\footnotetext{
103 Ibid., Note 13.09.

104 Ibid., Note 13.05 .

105 Ibid., Note R14.04.

106 Ibid., Note 13.11.

107 Ibid., Note 13.12.
} 
application claiming priority within the priority period occurred in spite of all due care or was unintentional. ${ }^{108}$ In addition, it was observed that there is no provision under the PCT corresponding to the provision in Article 13(3) PLT for the restoration of the right of priority where a copy of the earlier application is not filed within the prescribed time limit. ${ }^{109}$

\subsection{Restoration in the priority period}

The proposals prepared by the International Bureau in relation to introducing provisions in the PCT Rules for restoration of the right of priority similar to those in the PLT were extensively discussed in the Working Group on the Reform of the PCT. There was general agreement in the Working group with the idea of providing for a means of restoration of priority rights, during the international phase of the PCT procedure. ${ }^{110}$ In the beginning the Working group was divided as to whether the appropriate criterion for the restoration of a right of priority was that the failure to file the international application within the 12-month priority period was "unintentional" or occurred "in spite of due care" having been taken, noting that those two alternatives were provided for in Art.13(2)(iv) PLT. ${ }^{111}$ Eventually, it was decided to leave the decision as to the applicable criterion to each receiving Office, which at its option can decide to either apply the "unintentionality" or the "due care" criterion, or (at the request of the applicant) both. ${ }^{112}$

The Working Group on the Reform of the PCT realized the complexity of the resulting situation, in particular, whether a designated Office in the national phase is obliged to recognize a decision to restore a right of priority taken by a receiving Office in the international phase. It was agreed that a decision by the receiving Office to restore the right of priority would be binding on those designated Offices that applied the same or a less strict criterion. However, a designated Office that applies a stricter criterion than the receiving Office would not be bound by the receiving Office's decision but would be permitted to decide the matter in the national phase based on its own criterion. ${ }^{113}$ In addition, the Working Group noted that a decision to restore a right of priority based on

108 "Study regarding the Interface between the Draft Patent Law Treaty and the Patent Cooperation Treaty" (prepared by Leslie Lewis and Busso Bartels), Document SCP/2_St (March 1999), Item 13.02.

${ }^{109}$ Ibid., Item 13.03.

110 "Summary of the session" - "Changes Related to the PLT" (prepared by the Chair), Document PCT/R/WG/1/9 (November 2002), Item 22 (i).

${ }^{111}$ Ibid., Item 22 (iii).

112 "Options for Restoration of the right of priority: 'unintentionality' criterion; 'due care' criterion; retain priority claim for international phase leaving restoration for national phase" (prepared by the International Bureau), Document PCT/R/WG/4/1 (March 2003), Item 9.

See http://www.wipo.int/meetings/en/details.jsp?meeting_id=4817.

113 "Summary of the Session" (prepared by the Chair), Document PCT/R/WG/4/14 (May 2003), Item 40.

See http://www.wipo.int/meetings/en/details.jsp?meeting_id=4817. 
the criterion of "due care" would be binding on designated Offices that applied the "unintentional" criterion. ${ }^{114}$

The time limit for filing a request for restoration of the right of priority before the receiving Office as introduced on April 1, 2007, was set to be 2 months from the expiry of the priority period [PCT Rule 26bis.3(a); also see $\$ 4.3$ ]. This provision is in line with Article 13(2) and Rule 14(4)(a) PLT. Effective July 1, 2008, an extension of the time limit to pay the fee for restoration was implemented in PCT Rule 26bis.3(d). ${ }^{115}$ The extension was regarded possible because the decision by the receiving Office on a request for restoration of the right of priority does not affect the processing of an international application in the international phase, of the relevant dates for the purposes of prior art in the international search and preliminary examination or of the date of international publication because, even if the receiving Office refuses the request to restore the right of priority, the priority claim remains in the international application (see PCT Rule 26bis.2(c)(iii): a priority claim shall not be considered void only because the international application has an international filing date which is later than the date on which the priority period expired, provided that the international filing date is within the period of two months from that date). ${ }^{116}$

Where a receiving Office intends to refuse (totally or in part) the request for restoration of the right of priority, the applicant is given the opportunity to make observations within a time limit which must be reasonable under the circumstances [PCT Rule 26bis.3(g)]. This provision is in line with Article 13(6) PLT. ${ }^{117}$

In the corresponding PCT Rule 49ter.2 (entry into force on April 1, 2007) in relation to a request for restoration of the right of priority before the designated Office, the applicant, surprisingly, is given only 1 month to file the request. ${ }^{118}$ According to PCT

Rule 49ter.2(b)(i) this 1-month time limit is to be calculated from the time limit for entry into the national/regional phase before the designated Office [PCT Article 22]. The initial

\footnotetext{
${ }^{114}$ Ibid., Item 40.

115 "Report" (adopted by the Working Group), Document PCT/R/WG/9/8 (April 2007), Item 154. See http://www.wipo.int/meetings/en/details.jsp?meeting_id=12542.

${ }_{116}$ Ibid., Item 155.

${ }^{117}$ Comment by the International Bureau: "Note that, since the PCT is generally silent on such matters, the availability of hearings and appeals in respect of decisions by the receiving Office" under PCT Rule 26 bis.3(g) is "neither required or precluded by the Treaty but is left to national law and practice".

"Restoration of the right of priority" (prepared by the International Bureau), Document PCT/R/WG/7/3 (April 2005), Annex I, p. 14.

See http://www.wipo.int/meetings/en/details.jsp?meeting_id=7129.

118 "Restoration of the Right of Priority" (prepared by the International Bureau), Document PCT/R/WG/5/7 (September 2003), Annex I, p. 15.

See http://www.wipo.int/meetings/en/details.jsp?meeting_id=5085.
} 
proposal by the International Bureau contained a time limit of 2 months. ${ }^{119}$ Later on, the request for restoration of the right of priority before the designated Office should be made "at the time of entry into the national phase". ${ }^{120}$ PCT Rule 49ter.2(b)(i) would have been in alignment with the requirements in the PLT if the time limit specified in the Rule were 2 months after entry into the national/regional phase to file the request for restoration of the right to priority. ${ }^{121}$

Where a designated Office intends to refuse (totally or in part) the request for restoration of the right of priority, the applicant is given the opportunity to make observations within a time limit which must be reasonable under the circumstances [PCT Rule 49ter.2(3)]. This provision is in line with Article 13(6) PLT.

Upon adopting PCT Rule 26bis.3 (restoration of right of priority by the receiving Office), PCT Rule 49ter.2 (effect of restoration of right of priority by the receiving Office) and PCT Rule 49 ter.2 (restoration of right of priority by the designated Office), options were created for receiving and designated Offices to declare that their national law is not compatible with that provision. At present, the list of States with such reservations is still rather substantial. ${ }^{122}$ This reduces the scope of applicability of the provision of restoration of the right to priority under the PCT.

\subsubsection{Definition of the "priority period"}

In view of the introduction of the option to request restoration of the right to priority in PCT Rule 26bis.3 (receiving Office) and Rule 49ter.2 (designated Office) it was considered necessary to introduce a definition of the term "priority period" into the PCT. ${ }^{123} \mathrm{An}$

119 "Options for Restoration of the right of priority: 'unintentionality' criterion; 'due care' criterion; retain priority claim for international phase leaving restoration for national phase" (prepared by the International Bureau), Document PCT/R/WG/4/1 (March 2003), Annex II, pages 7-9. In a comment by the International Bureau is was noted that although at that time the PLT had not yet entered into force "it is proposed to incorporate into the PCT Regulations a provision with the same requirements as under PLT Article 13(2) and PLT Rule 13(4) and (5)... so as to oblige all designated and elected Offices to provide for the restoration of the right of priority".

${ }^{120}$ See "Summary of the Session" (prepared by the Chair), Document PCT/R/WG/4/14 (May 2003), Item 43 (g).

${ }^{121}$ In the opinion of the author the remark in the "Summary of the Session" in Document $\mathrm{PCT} / \mathrm{R} / \mathrm{WG} / 4 / 14$ under Item 43 (g) was not correct (absence of a time limit) and the previous setting of a 2-month period for filing the request for restoration before the designated Office in Document PCT/R/WG/4/1, Annex II, p. 7 was forgotten. This can be inferred from the comment in document PCT/R/WG/5/7, Annex I, p. 15: "Upon further consideration, it would appear reasonable to give the applicant at least one month from the applicable time limit under Article 22 to request restoration before the designated Office."

${ }^{122}$ A list of receiving Offices with a reservation under PCT Rule 26bis.3(j) and designated Offices with a reservation under PCT Rule 49ter.1 $(\mathrm{g})$ and/or Rule 49ter.2(h) can be found on the WIPO website.

See http://www.wipo.int/pct/en/texts/reservations/res incomp.html.

123 "Restoration of the right of priority" (prepared by the International Bureau), Document PCT/R/WG/7/3 (April 2005), Annex I, p. 2. 
implicit definition of the term priority period in the PCT could be derived from the wording "being a date falling within the period of 12 months preceding the international filing date" in an earlier version of PCT Rule 4.10(a)(i) in relation to the declaration of priority. ${ }^{124}$ To avoid confusion a definition of the term "priority period" was added to the PCT Regulations on April 1, 2007 [PCT Rule 2.4]. In addition, it was clarified that PCT Rule 80.5 (extension due to non-working days) would apply mutatis mutandis to the priority period [PCT Rule $2.4(\mathrm{~b})] .{ }^{125-126}$

It is noted that the PLT uses the term "priority period" without definition. ${ }^{127}$ This is not a problem because no time limits need be calculated under the PLT.

\subsubsection{Automatic retention of priority claims}

The Working Group on the Reform of the PCT discussed and accepted a proposal to provide for the automatic retention, during the international phase, of a priority claim where the international application has an international filing date which is later than the date on which the priority period expired but within the period of 2 months from that date. ${ }^{128}$ Such a priority claim would be retained irrespective of whether the applicant requests the receiving Office to restore the right of priority and even where such a request is made but refused by the receiving Office. In other words, such a priority claim would not be considered not to have been made (as would be the case under the PCT Regulations in force at that time) and would therefore be taken into account during the international phase for the purposes of international search and international preliminary examination, and for the computation of time limits, including that for entry into the national phase. It was also noted that such retention of a priority claim did not affect the question of relevant prior art for the purposes of the international search under PCT

${ }^{124}$ The version of PCT Rule 4.10(a)(i) with this wording was in force from July 1, 1998 to March 31, 2007.

${ }^{125}$ Also see Article ${ }_{4} \mathrm{C}(1)$, (2) and (3) Paris Convention. In particular, Article ${ }_{4} \mathrm{C}(1)$ Paris Convention specifies two durations for priority periods: "The periods of priority ... shall be twelve months for patents and utility models, and six months for industrial designs and trademarks." See http://www.wipo.int/treaties/en/ip/paris/trtdocs woozo.html

${ }^{126}$ In view of the wording of PCT Rule 2.4(a), it seems that this Rule is only interpreting the term "priority period" but does not actually fix a "time limit" in the sense of PCT Article 48. Moreover, the introduction of PCT Rule $2.4(\mathrm{~b})$ would seem to suggest that only PCT Rule 80.5 is considered to be applicable to the "priority period" but not any other Rule. In other words, since there would not have been a need for PCT Rule $2.4(\mathrm{~b})$ if the "priority period" would be considered a time limit fixed in the PCT or its Regulations, the inclusion of PCT Rule 2.4(b) shows that it was meant as an exception.

${ }^{127}$ See Article 13 and Rule 14 PLT. The term "priority period" is not defined in the Explanatory Notes on the PLT and "Explanatory Notes on the Patent Law Treaty and Regulations under the Patent Law Treaty adopted by the Diplomatic Conference on June 1, 2000" (prepared by the International Bureau), Diplomatic Conference for the Adoption of the PLT, Document PT/DC/48 Prov. (November 2000).

128 "Restoration of the Right of Priority" (prepared by the International Bureau), Document $\mathrm{PCT} / \mathrm{R} / \mathrm{WG} / 5 / 7$ (September 2003), Item 6. 
Rule 33, since the relevant date for the purposes of the international search was in any case the international filing date. ${ }^{129}$

There was some discussion in the Working Group about how to phrase the retention of the priority claim. The initial proposal used the term "canceled" in PCT Rule 26bis.2(c): "A priority claim shall not be canceled only because ...". ${ }^{130}$ In the final version of PCT Rule 26bis.2(c) the wording "not be considered void only" was introduced (entry into force on April 1, 2007): ${ }^{131}$

PCT Rule 26bis.2(c): A priority claim shall not be considered void only because:

(iii) the international application has an international filing date which is later than the date on which the priority period expired, provided that the international filing date is within the period of two months from that date.

Without knowing the background, the meaning and implication of PCT Rule 26bis.2(c)(iii) is difficult to understand; in a Practical Advice in the PCT Newsletter the matter was explained. ${ }^{132}$

\subsection{No restoration in the period for filing of a copy of the priority application under the PCT}

There is no provision under the PCT corresponding to the provision in this paragraph for the restoration of the right of priority where a copy of the earlier application is not filed within the prescribed time limit. ${ }^{133}$ The intention of Article 13(3) PLT is to provide a safeguard in the situation where the applicant cannot submit a copy of an earlier application within 16 months from the priority date [as required by Rule 4(1) PLT], because of a delay in the Office with which the earlier application was filed. In such cases, Article 13(3) and Rule 14(6) and (7) PLT provide for restoration of priority rights if the applicant has filed a request for a copy of the earlier application with the Office with which the earlier application was filed by the end of 14 months from the priority date, and makes a request for restoration within 16 months from the priority date.

129 "Summary of the Session" (prepared by the Chair), Document PCT/R/WG/5/13 (November 2003), Item 34.

See http://www.wipo.int/meetings/en/details.jsp?meeting_id=5085.

${ }^{130}$ Ibid., Item 43.

131 "Report" (adopted by the Assembly), PCT Assembly, $34^{\text {th }}$ (15 ${ }^{\text {th }}$ ordinary) session, Document PCT/A/34/6 (October 2005), Annex II.

See http://www.wipo.int/meetings/en/details.jsp?meeting_id=9006.

132 "Practical Advice" in PCT Newsletter 12/2009.

See http://www.wipo.int/pct/en/newslett/practical_advice/pa_12200g.html.

Also see the "Practical Advice" in PCT Newsletter 04/2007 and 09/2009.

133 "Study regarding the Interface between the Draft Patent Law Treaty and the Patent Cooperation Treaty" (prepared by Leslie Lewis and Busso Bartels), Document SCP/2_St (March 1999), Item 13.02. 
The Working Group on Reform of the PCT has, as far as known, never discussed the topic. A reason for this may be that there is simply no need for any such provision: PCT Rule 17.1(c) already gives the applicant the guarantee that, if he was not able to furnish the priority document during the international phase (for whatever reason), he will be given another opportunity for furnishing the priority document during the national phase. In addition, the advance in technology away from requesting paper copies and switching to the electronic exchange of priority documents between Offices, Authorities and the International Bureau appears to have diminished the need for introducing a remedy in the sense of Article 13(3) PLT. To this end, already on January 1, 2004 a new paragraph (b-bis) was added to PCT Rule 17.1 relating to the possibility that priority documents may be available to the receiving Office or to the International Bureau from digital libraries. ${ }^{134-135}$ The latter provision is in line with Rule 4(3) PLT.

\section{Conclusion and recommendation}

The goal of the Patent Law Treaty (PLT) is to "streamline and harmonize" formal requirements of national and regional patent Offices for the filing and processing of national and regional patent applications, the maintenance of patents and certain additional requirements related to patents or patent applications. The PLT does not establish a completely uniform procedure for all PLT Contracting Parties, but a party to the PLT is free to require fewer, or more user-friendly, requirements than those prescribed in the PLT.

Both the PLT and the Patent Cooperation Treaty (PCT) are international treaties on patent law. As the PCT cannot become a "Contracting Party" to the PLT, there is, ex lege, no reason for the PCT to comply with the requirements set by the PLT. However, because the PLT incorporates by reference so many standards prescribed by the PCT as to the form and contents of international applications, an adequate alignment of the basic requirements of the PCT with those of the PLT would be desirable, if not compulsory. In view of the "intimate" relationship between the PLT and the PCT it is strange that a number of fundamental provisions of the PLT have not been incorporated into the PCT.

The International Bureau of WIPO and the Working Group on Reform of the PCT have undertaken a substantial effort to promote alignment of the PCT with the letter and spirit of the PLT. However, in a number of situations the Working Group concluded that

134 "Changes related to the Patent Law Treaty (PLT): Right of priority and priority claims " (prepared by the International Bureau), Document PCT/R/WG/2/3 (March 2002), Item 4 and Annex. See http://www.wipo.int/meetings/en/details.jsp?meeting_id=4554.

${ }^{135}$ Effective July 1, 2012, the time limit in PCT Rule 17.1(b-bis) for making the request to obtain the priority document from a digital library will be harmonized with respect to the time limits PCT Rule 17.1(a) and (b). In addition, the (unused) option of requesting that a receiving Office obtain a priority document will be removed.

See "Proposed Amendments of Rules 17.1(b-bis) and 20.7(b)" (prepared by the International Bureau), PCT Working Group, Document PCT/WG/4/10 Rev. (May 2011), Annex IV. See http://www.wipo.int/meetings/en/details.jsp?meeting_code=pct/wg/4. 
"bending" the PCT Rules to accommodate certain PLT provisions would require amendment of the Articles of the PCT, which is largely impossible. In other situations a certain amount of reluctance could be sensed on the part of the Working Group to deal with the matter. In the reports of the meetings of the Working Group often sentences can be found suggesting that "any proposals to align other provisions under the PCT not be presented to the Working Group until a future session, as this does not appear to be a high priority." In later meetings of the Working Group the matter was never dealt with again.

\subsection{Amendment of the PCT in view of the PLT}

The majority of the amendments to the PCT in view of the alignment with the requirements of the PLT were implemented into the PCT Rules on April 1, 2007. In the context of this Chapter the following issues were extensively discussed:

- Correction of defects in priority claims [PCT Rule 26bis.2].

- Restoration of the right of priority by the receiving Office [PCT Rule 26bis.3] and by the designated Office [PCT Rule 49ter].

- Rectification of obvious mistakes [PCT Rule 91].

Also on April 1, 2007, new Rule 20 PLT entered into force dealing with the accordance of the international filing date including the incorporation by reference of missing parts or missing elements in the international application; an in-depth discussion of this subject was published elsewhere. ${ }^{136}$

Already on January 1, 2003, PCT Rule 49.6 was introduced in relation to the reinstatement of rights after failure to comply with the requirements for national/regional phase entry within the time limits under PCT Articles 22 and 39(1) [see \6].

\subsection{Duration and relief in respect of time limits fixed by the Office}

Due to the tight time schedule in the international phase, relief in respect of time limits under the PCT is rather limited. In addition, the duration of the time limits in the PCT Rules is often not specified but only indicated as "within a time limit which shall be reasonable under the circumstances". However, the term "reasonable under the circumstances" lacks a definition in the PCT Rules; it also cannot be found in the PCT Applicant's Guide and the PCT Administrative Instructions. The preferred option would be to delete the notion "reasonable under the circumstances" from the PCT in its entirety and replace it by a time limit with a specified (minimum) duration. Where possible, the duration of the time limit should be set to be (at least) 2 months, thereby promoting alignment of the PCT with the provisions of the PLT.

${ }^{136}$ Cees Mulder: "Filing date requirements under the PCT - Alignment with the PLT?", The WIPO Journal, Volume 2, Issue 2 (2011), pp. 173-195. An updated version of this article is included in Chapter IV of this thesis. 
If the term is maintained in the PCT, a definition including a minimum duration should be incorporated in the PCT Rules (e.g. in PCT Rule 80). Using undefined terms in legislation, in particular in patent law treaties, puts the applicant in an uncertain position. To make things worse, there are time limits in the PCT without a specified duration and where also the term "reasonable under the circumstances" is not included [see e.g. PCT

Rule 13 ter.1(a) and (b), and Rule 6o.1(g)]. The lack of the indication of any duration of time limits should be remedied.

In addition, the frequently-found formulation in the PCT Rules that the time limit "may be extended by the" receiving Office or other responsible Authority "at any time before a decision is taken" [see e.g. PCT Rule 26.2, 55.2(c), 55.3(c) and 60.1(a)] also leaves the applicant in an uncertain position: if the Office or Authority has already taken the decision, then there is no remedy in the international phase. So if the applicant finds out that he has overrun a time limit, he must immediately make a phone call and ask whether the decision has already been taken. This type of discretionary extension should be deleted from the PCT Rules in its entirety. Preferably, it should be replaced by a formulation as can be found in PCT Rule 66.2(e): "The time limit for replying to the notification may be extended if the applicant so requests before its expiration." Such a formulation would be compliant with Article 11(1)(i) PLT.

Yet another unclear formulation with respect to the duration of time limits can be found in PCT Rule 26bis.3(d), last sentence, stating that (emphasis added): "The time limit for payment of the fee may be extended, at the option of the receiving Office, for a period of up to two months from the expiration of the time limit applicable under paragraph (e)" ${ }^{137}$ The Rule leaves it to the receiving Offices to decide whether they wish to extend the time period ex officio or whether they only wish to extent the time limit on request from the applicant and/or whether such request would need to be submitted prior to the expiration of the initial time period.

It can be concluded that the existing provisions in the PCT Regulations with respect to the extension of time limits cause a great deal of uncertainty on the side of the applicants and give too much freedom for the receiving Offices and International Authorities who can freely set and determine the duration of the time limits.

During the amendment round of the Regulations under the PCT in April 2007 when a number of PCT provisions was aligned with the provisions in the PLT, the duration of a number of time limits in the PCT was better defined and amended to become 2 months. In addition, the time limits in the newly introduced provisions were in most cases also set to be 2 months. As far as known, the PCT system did cope very well with these 2-month time limits. So it seems that despite the fears with respect to the "tight time schedule" in the international phase, the system is able to deal with situation where the applicants are

${ }^{137}$ This sentence was added on July 1, 2008.Also the PCT Applicant's Guide - International Phase, Item 5.064 does not give an explanation. 
given more certainty by allowing them more time. This opens a window of opportunity to better define and stretch the duration of other time limits in the international phase of the PCT and, in addition, to consider putting in place a system of allowing extension of a number of time limits. This would promote further alignment of the provisions of the PCT with those of the PLT.

\subsection{Continued processing}

There are no provisions under the PCT for continued processing where the applicant has failed to comply with a time limit fixed by the Office, as provided for under Article 11(2) PLT. The Working Group on Reform of the PCT considered that the inclusion into the PCT Regulations of general provisions providing for the extension of time limits was already regarded as problematic in view of a proper functioning of the PCT system. Adding an additional time limit for allowing the applicant to benefit from continued processing was regarded a bridge too far for the tight timeframe of the $\mathrm{PCT}$.

Article 11 PLT obliges a PLT Contracting Party to provide relief in respect of time limits "fixed by the Office for an action in a procedure before the Office". Such relief may be in the form of an extension of the time limit and/or continued processing. So, in principle, there is no obligation in the PLT to provide for the extension of an Office time limit. However, a PLT Contracting Party that does not provide for extension after expiration of the time limit [Article 11(1)(ii) PLT] is obliged to provide for continued processing [Article 11(2) PLT]. The PCT does not allow for an extension of time limits after expiry of the time limit. In some cases the PCT allows an extension of the time limit before the International Authority takes a decision, but this results in a very uncertain situation for the applicant. Only in one case the applicant can request extension of the time limit for replying to a notification prior to the expiration of the time limit [PCT Rule 66.2(e)].

Together with the remarks as indicated in the previous paragraph, the lack of continued processing further renders the life of an international application from the perspective of the applicant unreliable and unpredictable.

If a receiving Office or the International Bureau considers the international application withdrawn, even if this withdrawal is caused by an erroneous determination on the side of the receiving Office or the International Bureau, such a decision can, in principle, not be appealed, because the PCT does not provide for an appeal during the international phase. ${ }^{138}$ As a relief the $P C T$ provides that an international application which is (considered) withdrawn may enter the national phase before each designated Office while applying national law to remedy the loss of rights. However, this is an inefficient and cost-consuming procedure.

${ }^{138}$ It is noted that providing an "appeal" is not prescribed by the PLT. However, the phrase: "an action before a board of appeal or other review body constituted in the framework of the Office" is used in Rule 12(5)(a)(v) and Rule 13(3)(i) PLT in relation to exceptions allowed under Article 11(3) and 12(2) PLT, respectively. 
It would be welcomed by the applicants if at least in the case that the international application is considered withdrawn, a remedy such as continued processing were introduced into the PCT, e.g. by adding a PCT Rule 82quinquies to this effect. ${ }^{139}$ Introducing such a Rule with a limited scope and seeing how it works out in practice is conceivable.

\subsection{Restoration in the priority period}

By adopting PCT Rule 26bis.3 relating to the restoration of the right to priority by the receiving Office, the PCT was aligned with the corresponding provision in Article 13(2) $\mathrm{PLT}$. The request for restoration can be based on that the failure to file the international application within the 12-month priority period occurred in spite of due care required by the circumstances having been taken or was unintentional, depending on which criterion is applied by the receiving Office. The time limit for filing a request for restoration of the right of priority before the receiving Office was set to be 2 months from the expiry of the priority period, which is in line with the provisions in the PLT. In the corresponding PCT Rule 49 ter. 2 in relation to a request for restoration of the right of priority before the designated Office, the applicant is given only 1 month to file the request; this time limit should be amended to become 2 months.

Following the adoption of PCT Rules for restoration of the right of priority, options were created for receiving and designated Offices to declare that their national law is not compatible with that provision. At present, the list of PCT Contracting States with such reservations is still rather substantial thereby reducing the scope and applicability of the provision of restoration of the right to priority under the PCT. The WIPO should actively promote the reduction of the number of reservations.

\subsection{Restoration in the period for filing of a copy of the priority application}

There is no provision under the PCT corresponding to the provision in Article 13(3) PLT relating to the restoration of the right of priority where a copy of the earlier application is not filed within the prescribed time limit. The intention of Article 13(3) PLT is to provide a safeguard in the situation where the applicant is unable to submit a copy of an earlier application within 16 months from the priority date because of a delay in the Office with which the earlier application was filed. As patent applications between Offices are more and more exchanged by electronic means, the need for implementing a provision as in Article 13(3) PLT seems not of high relevance. Another reason is that the PCT system already provides enough flexibility to file the required certified copy of the priority document [PCT Rule 17.1(c)].

139 This new Rule could best be inserted after PCT Rule 82quater "Excuse of delay in meeting time limits due to force majeure" which will enter into force on July 1, 2012. 


\section{List of Abbreviations}

EPC European Patent Convention

EPO European Patent Office

epi Institute of Professional Representatives before the European Patent Office

Euro-PCT international application for which the European Patent Office is designated or elected Office [cf. Article 153(2) EPC]

Guidelines Guidelines for Examination in the European Patent Office (edition April 2010)

IB International Bureau

IPEA International Preliminary Examining Authority

OJ EPO Official Journal of the European Patent Office

PC Paris Convention (Stockholm Act)

PLT Patent Law Treaty

PCT Patent Cooperation Treaty

SCP Standing Committee on the Law of Patents

WIPO World Intellectual Property Organization

USPTO United States Patent and Trademark Office 


\section{List of Publications}

Parts of Chapter I in relation to the Negotiation History of the PLT have been submitted for publication in:

Intellectual Property Quarterly

Cees Mulder: On the Negotiation History of the Patent Law Treaty.

Chapter II is an updated version of:

Cees Mulder and Derk Visser: Filing date requirements under the EPC - an option to extend subject-matter?

published in epi Information 2|10, pp. 44-48 (2010).

Chapter III is an updated version of:

Cees Mulder and Derk Visser: Filing date requirements under the EPC - filing by reference to a previously filed application

in epi Information 4|10, pp. 126-129 (2010).

Chapter IV is an updated version of:

Cees Mulder: Filing date requirements under the PCT - Alignment with the PLT? published in The WIPO Journal, Volume 2, Issue 2, pp. 173-195 (2011).

Chapter $\mathrm{V}$ is an updated version of:

Cees Mulder: Periods and remedies under the EPC - Compliance of the EPC with the PLT - Part I - Extension of periods and further processing to be published in European Intellectual Property Review, Issue 1 (2012).

Chapter VI is an updated version of:

Cees Mulder: Periods and remedies under the EPC - Compliance of the EPC with the PLT - Part II-Re-establishment of rights to be published in European Intellectual Property Review, Issue 2 (2012). 


\section{Summary and Conclusions}

In this thesis, results are presented of a study on the alignment of the European Patent Convention and the Patent Cooperation Treaty with requirements of the Patent Law Treaty. The Patent Law Treaty (PLT) was drafted with the aim to "streamline and harmonize" formal requirements set by national or regional Patent Offices for the filing of national or regional patent applications and the maintenance of patents. The PLT provisions refer as much as possible to the provisions of the Patent Cooperation Treaty (PCT) and its Regulations in order to keep the PLT as simple as possible and to avoid creating different international standards regarding patent formalities with respect to national and international applications. The harmonization of procedures under national and regional patent laws was expected to result in easier access to worldwide patent protection and cost reduction for applicants in those procedures.

The Patent Law Treaty does not harmonize substantive patent law; instead, the approach is more to the administrative side of the patent process. Inventors seeking patent protection must follow certain rules which vary from country to country. The PLT aims to simplify the rules and make them the same for all Contracting Parties. As is discussed in this thesis, the PLT did not achieve this goal.

During the last decade, requirements of the Patent Law Treaty have been implemented in, for instance, the Patent Cooperation Treaty (PCT; April 2007) and in the European Patent Convention ("EPC 2000"; December 2007). When studying and comparing the outcome of the implementation, not much "harmonization and streamlining" can be detected between the PCT and the EPC. In fact, there was more coherence between the EPC and the PCT with respect to requirements for filing patent applications before both patent treaties were aligned with the PLT. This is all the more peculiar when it is taken into account that more than $50 \%$ of the patent applications received by the European Patent Office (EPO) are not European patent applications but international applications, for which the EPO in its capacity of "receiving Office" has to apply the provisions of the PCT. The PCT provisions deviate in crucial aspects from the corresponding provisions in the EPC, such that the response from the EPO is significantly different depending on the treaty under which the application was filed. This should not be the case.

By way of example, if an applicant or an inventor files a European patent application at the European Patent Office (EPO) under the provisions of the European Patent Convention (EPC) or, alternatively, files an international application at the EPO, as receiving Office under the provisions of the Patent Cooperation Treaty $(P C T)$, the same EPO has to deal with totally different requirements with respect to:

- The accordance of a date of filing,

- Filing an application by reference to a previously filed application, or

- Filing missing parts of the description or missing drawings. 
In practice, this leads to "strange" situations, such as, e.g.:

- Upon receiving a European patent application, the EPO will accord a date of filing if the applicant only files a description; claims are not a filing date requirement. However, the EPO acting as receiving Office under the PCT, will not accord an international filing date to an international application if the applicant does not file at least one claim.

- Filing an international application by reference to a previously filed application is not possible under the $\mathrm{PCT}$, whereas this is allowable under the provisions of the EPC.

O The EPO, acting as receiving Office for an international application, allows an applicant to file (an entire set of) claims or the entire description as "missing element", whereas this is clearly not allowable under the provisions of the EPC where only "missing parts of the description or missing drawings" can be filed.

- If a missing element or part is to be added later on into an international application, based on an earlier priority application, such priority claim must have been made on the original filing date, i.e. the "date on which one or more elements referred to in PCT Article 11(1)(iii) were first received by the receiving Office".

If an applicant requests insertion of a missing part of the description or missing drawings into an already filed European patent application, based on an earlier priority application, the priority claim in question may be added later on.

While aligning the various national patent laws and regional patent treaties with requirements of the relatively new Patent Law Treaty (PLT), each of the involved national or regional patent Offices seemingly interpreted the PLT from their own perspective without much consultation with colleague Offices.

For the purpose of this thesis, a number of subjects of the Patent Law Treaty have been selected. These subjects of study are:

1) Requirements for the accordance of a filing date with focus on the following three issues:

- The basic requirements for according a filing date;

o The filing date in those cases where a missing part of the description or a missing drawing is filed;

- The filing of an application by reference to a previously filed application.

2) Relief in respect of time limits including continued processing and reinstatement of rights, after a finding of due care or unintentionality by the Office.

3) Restoration of the priority right.

None of the above subjects was present in the Draft PLT put before the Committee of Experts on the Patent Law Treaty at its first session in December 1995, although some of the later-inserted provisions were modeled after texts in the Basic Proposal submitted to 
the 1991 Diplomatic Conference on the "Treaty supplementing the Paris Convention for the Protection of Industrial Property as far as Patents are Concerned".

\section{Negotiation history of the Patent Law Treaty.}

Since the continuation of the 1991 Diplomatic Conference in The Hague on the harmonization of the substantive provisions of patent laws had become impossible in view of the position taken by the Delegation of the United States of America, it was agreed in 1995 that another approach for promoting harmonization, covering matters concerning the formality requirements of national and regional patent procedures, would be initiated by the World Intellectual Property Organization (WIPO). Five sessions of the Committee of Experts on the Patent Law Treaty, and three sessions of its successor, the Standing Committee on the Law of Patents (SCP), were held to develop the "Basic Proposal" as presented to the Diplomatic Conference for the Adoption of the Patent Law Treaty, which was held in Geneva from May-June 2000.

During the negotiation process, a number of provisions in the PLT were brought forward by the Delegations in order to accommodate the local practice in their home countries. If no agreement could be reached on the implementation of such a requirement, often the desired amendment was incorporated in the PLT but without prescribing it as mandatory. As a consequence, the Patent Law Treaty contains a puzzling mix of compulsory requirements ("shall") and optional requirements which may be implemented as compulsory ("may require") by a PLT Contracting Party. Such diversity of requirements does not stimulate the achievement of the goal of the PLT to "streamline and harmonize" formal requirements set by national and regional Patent Offices for the filing of national or regional patent applications and the maintenance of patents.

From studying the documents relating to the negotiation history of the Patent Law Treaty, it can be inferred that the role of the World Intellectual Property Organization (WIPO) in the negotiation process resulting in the PLT was more of a facilitating nature than aimed at obtaining a Treaty that encompasses mainly compulsory requirements. The inclusion of optional requirements should only have been allowed in a limited number of exceptional cases. On the other hand, it can be understood that the desire to reach an agreement on a Patent Law Treaty, often made it necessary to bridge differences; this was not always possible, and this is one of the reasons why there are so many alternative routes in the PLT.

As the Patent Law Treaty does not directly involve the World Intellectual Property Organization, because there are no centralized functions, the International Bureau of WIPO merely acts as depository of the PLT and is not in a position to give an official interpretation of the Treaty, as such interpretation is the exclusive competence of the 
PLT Contracting Parties. When asked, the WIPO will provide assistance to an aspirant PLT Contracting Party. Example texts have been prepared by the International Bureau of WIPO, which can be used as a guidance on how the requirements of the PLT can be implemented in the national/regional law; these texts have no official status. An aspirant PLT Contracting Party is, of course, free to make its own choices when implementing the Patent Law Treaty in its national/regional patent law. Nevertheless, it is believed that such textual suggestions would be helpful in understanding and illustrating the scope of the PLT and would stimulate a more uniform implementation of the PLT in national/regional patent laws. A more active role of the World Intellectual Property Organization would be welcomed in this respect.

\section{Filing date requirements}

Article 5 of the PLT governs the requirements for the accordance of a date of filing. In particular, Article 5(1) PLT prescribes the maximum and minimum number of elements of an application required for according a filing date. First, the Office receiving the application documents needs to be satisfied that the elements which it has received are intended as an application for a patent. Second, the Office must be provided with indications which identify the applicant and/or allow the applicant to be contacted. Instead of such indications, the Office may accept evidence allowing the identity of the applicant to be established or allowing the applicant to be contacted by the Office. Third, the Office must have received a disclosure of the invention, either in the form of what appears to be a description or, where permitted, a drawing in place of that description. In addition, a Contracting Party is obliged to accept, at the time of filing, the replacement of the description and any drawings in an application by a reference to a previously filed application, subject to certain formal requirements [Article 5(7) PLT].

The PLT also provides rules for establishing a filing date in those cases where a part of the description or drawing is missing from the initially filed application [Article 5(6) PLT]. Normally, the filing of a missing part or drawing results in the accordance of a later filing date. However, if the application claims priority of an earlier application, and the missing part or drawing is "completely contained" in the earlier application, the originally accorded filing date will be maintained.

\subsection{European Patent Convention}

In Chapter II of this thesis, the requirements in the European Patent Convention (EPC) for the accordance of a date of filing and the option to file missing parts of the description or missing drawings are discussed in relation to requirements of the PLT. The filing date requirements of the PLT were fully adopted in the EPC [Rule 40(1) EPC]. 
With respect to the filing of missing parts of the description or missing drawings based on content which is "completely contained" in an earlier application from which priority is claimed, the Guidelines for Examination in the European Patent Office implementing Rule 56(3) EPC allow an applicant to add the priority claim after the filing date of a European patent application. This is a direct violation of Article 5(6)(b) PLT and, in addition, is in conflict with the requirement that a patent application may not be amended to contain subject-matter extending beyond the content of the application as filed [Article 123(2) EPC]. It is recommended to amend Rule 56(3) EPC to bring it into conformity with Article 5(6)(b) PLT. Alternatively, the section of the Guidelines should be amended to stipulate that, if an applicant desires to file missing items based on content in a priority application, the priority claim should have been made on the initial filing date of the application. This would bring the EPC in line with the requirements of the PLT.

In Chapter III of this thesis, the filing date requirements are discussed in relation to filing a European patent application by reference to a previously filed application. Upon implementing the "filing by reference" requirements, the EPO made its own selection from the mix of compulsory and optional requirements as given in Article 5(7)(a) and Rule 2(5)(b) PLT. In particular, Rule 40(2) EPC states that the applicant must state the filing date and number of that application and the Office with which it was filed, and indicate that the reference replaces the description and any drawings. In addition, Rule 40(3) EPC requires an applicant to file a certified copy of the previously filed application within two months of filing the application. Rule 40(3) EPC contains the additional requirement that the applicant must file a translation of the previously filed application in those cases, where that application is not in an official language of the EPO. Although both the filing of the copy and the translation of the previously filed application are mentioned in the same paragraph of Rule 40 EPC, the EPO has decided to treat these requirements differently. Whereas the filing of the copy is made compulsory for the accordance of the date of filing, the filing of the translation is considered as an issue of formalities. Hence, if an applicant does not file the certified copy of the previously filed application in due time, his application will not be treated as a European patent application. On the other hand, the date of filing already accorded to his application will be retained if the applicant does not furnish a required translation of the previously filed application. The fact that one element in a paragraph in a Rule titled "Date of filing" is treated as a filing date requirement, whereas another element in the same paragraph is not, renders Rule 40(3) EPC unclear. It is recommended to move the requirement to furnish a required translation to another Rule.

In practice, the option of "filing by reference" appears already to have become outdated as a result of advances in transmission technology and should not be regarded as a preferred option for filing a patent application. Therefore, the option of "filing by reference" could be abolished in Rule 4O(1)(c) EPC, thereby at the same time deleting Rule 40(2) and (3) EPC. 
Although the implementation of filing date requirements in the EPC 2000 closely follows the PLT provisions, it has resulted in a system that is substantially more complicated than under the EPC 1973, thereby defying the aim of streamlining the PLT.

\subsection{Patent Cooperation Treaty}

In Chapter IV of this thesis, the requirements in the Patent Cooperation Treaty (PCT) for the accordance of a date of filing and the option to file missing parts of the description or missing drawings are discussed in relation to requirements of the PLT.

Both the PLT and the PCT are international treaties on patent law. The PCT cannot become a "Contracting Party" to the PLT. So there is, ex lege, no reason for the PCT to comply with the requirements set by the PLT. A main feature of the PLT is that it provides standardized formality requirements for patent applications which are filed with a national or regional patent Office. Instead of defining these requirements again or differently in the PLT, it was decided to incorporate by reference the provisions of the PCT and its Regulations, wherever appropriate, into the PLT. The main reason for this is that the PCT already regulates in detail the formality requirements with respect to patent applications. As the PLT is directly linked to the PCT, it seems "strange" that the PCT does not better "comply" with the basic requirements of the PLT, e.g. with respect to the accordance of the international filing date.

The International Bureau of WIPO and the Working Group on Reform of the PCT have undertaken a substantial effort to promote alignment of the PCT with the letter and spirit of the PLT. However, in a number of situations the Working Group concluded that "bending" the PCT Rules to accommodate certain PLT provisions would (also) require amendment of the Articles of the PCT which is largely impossible. In other situations a certain amount of reluctance could be sensed on the part of the Working Group to deal with the matter. In reports of the meetings of the Working Group often sentences can be found suggesting that "any proposals to align other provisions under the PCT would not be presented to the Working Group until a future session, as this does not appear to be a high priority." In later meetings of the Working Group the matter was never dealt with again.

In preparation for the Diplomatic Conference for the Adoption of the Patent Law Treaty, the International Bureau investigated how future changes to the PCT could be incorporated by reference into the PLT. This principle, which was not explicitly dealt with in the provisions of the Basic Proposal of the PLT, was implicitly assumed in order to make the interface between the PLT and the PCT viable over time. The International Bureau could not identify any identical or analogous provisions in other international treaties. Various options to deal with this problem were discussed at the Diplomatic Conference, resulting in the adoption of Article 16 and 17(2)(v) PLT. In addition, an "Agreed Statement" was formulated during the Conference, consolidating the relationship between the PLT and the PCT. The effect of Article 16(1) PLT is that any 
revisions, amendments and modifications to the PCT will only apply for the purpose of the PLT under certain conditions.

With respect to issues relating to the filing of an international application only the issue of filing missing parts of the description or missing drawings was incorporated in the PCT [PCT Rule 20.5]. Other issues prescribed in the PLT, such as the requirements for according an international filing date to an international application and the filing of a description and/or drawings by a reference to another application were not implemented.

With respect to the filing date requirements, PCT Article 11(1) prescribes a number of requirements which are much more restrictive than what is prescribed in Article 5(1) PLT. The most notorious difference is the compulsory presence of "a part which on the face of it appears to be a claim or claims" [PCT Article 11(1)(iii)(e)]. A way to circumvent this in the PCT would be to regard claims as a "legal fiction". A proposal to this effect, prepared in great detail by the International Bureau, included the introduction of a suitably worded pre-printed statement to be included in the Request Form as well as the presence of "claim-like" wording in the description. Unfortunately, the proposal was not accepted.

With respect to "filing by reference", the PCT was not aligned to the PLT. There was an initial proposal which would provide for a reference to another document replacing the description, drawings and claims. Later on, the matter of "filing by reference" in the sense of the PLT was not pursued in the Working Group on Reform of the PCT. With today's tools of filing an application electronically, providing for filing by reference has lost its advantages.

With respect to the filing of missing parts of the description or missing drawings, the PCT has "stretched" the requirements of the PLT by allowing applicants to file also a missing claim or claims [PCT Rule 20.5 PCT]. This would seem logical, because claims are a filing date requirement under the PCT. However, the PCT also allows an applicant to file, under the same provision, all the claims or the entire description as a so-called "missing element" [PCT Rule 20.3 and 20.6]. There is no equivalent provision in the PLT. All these possibilities have been incorporated in PCT Rule 20 implementing the filing date requirements, thereby making it one of the more complicated Rules in the PCT. Allowing an applicant to late file the entire description or the entire set of claims should not have been implemented in the PCT.

As said before, it is strange that a number of fundamental provisions of the PLT have not been incorporated into the PCT. This is all the more peculiar, because in earlier years flexibility to the PCT system was added by amending the Regulations under the PCT, while mitigating the rigidity of certain PCT Articles. On a number of occasions this resulted in inconsistencies between the PCT Articles and its Regulations. In the same spirit, it would have been possible to realize a better alignment between the PCT and the $\mathrm{PLT}$. In particular, mitigation of the compulsory presence of claims when filing an 
international application in view of the requirements in the PLT is desirable and would have been possible. Users of the PCT system would welcome a better alignment of at least some filing date-related requirements and provisions dealing with defects which may affect the filing date.

\section{Relief in respect of time limits}

Article 11 of the PLT governs the requirements for the extension of time limits and for "continued processing" of an application or a patent. In general, Article 11 PLT obliges a PLT Contracting Party to provide relief in respect of time limits. Such relief may be in the form of an extension of the time limit [Article 11(1) PLT] and/or continued processing [Article 11(2) PLT]. Relief in respect of the time limit is subject only to the filing of a request and, where applicable, to the payment of a fee. Accordingly, the applicant or owner concerned may not be required to state the grounds on which the request is based or to file evidence with the Office. In particular, a PLT Contracting Party is not permitted to make the grant of the relief under Article 11 PLT conditional on a finding of due care or unintentionality by the Office.

The relief a PLT Contracting Party is obliged to provide under Article 11(1) and (2) PLT is restricted to time limits "fixed by the Office for an action in a procedure before the Office". It is for each PLT Contracting Party to decide which time limits are fixed by the Office. A typical example of a time limit fixed by Offices is the time limit for response to an examiner's substantive examination report.

It is important to realize that Article 11(1) PLT does not oblige a PLT Contracting Party to provide for the extension of a time limit fixed by the Office. However, a PLT Contracting Party that does not provide for extension after expiration of the time limit [Article 11(1)(ii) $\mathrm{PLT}]$ is obliged to provide for continued processing under Article 11(2) PLT in respect of these time limits.

Article 12 PLT obliges a PLT Contracting Party to provide for the reinstatement of rights with respect to an application or patent following failure to comply with a time limit for an action in a procedure before the Office. In contrast to Article 11 PLT, where an applicant cannot be required to state the grounds on which the request is based, such reinstatement is subject to a finding by the Office that the failure occurred in spite of all due care required by the circumstances or, at the option of the PLT Contracting Party, was unintentional. In further contrast to Article 11 PLT, Article 12 PLT is not restricted to time limits fixed by the Office, although there are some exceptions.

\subsection{European Patent Convention}

In Chapter $\mathrm{V}$ of this thesis, the requirements in the European Patent Convention (EPC) for the extension of time limits and the remedy of further processing are discussed, whereas Chapter VI deals with the remedy of re- establishment of rights. 
The European Patent Convention (EPC) distinguishes two types of periods: the so-called "Office periods" and "Convention periods", depending on whether the duration of the period is specified by the European Patent Office (EPO) or fixed in an Article or Rule of the EPC, respectively.

If "a period to be specified" by the EPO is missed in grant proceedings or in ex parte appeal proceedings, further processing may be requested. There is only one exception in the EPC: further processing is ruled out if the applicant does not respond in due time to an invitation to repair deficiencies in the priority claim [Rule 59 EPC, but see $\$ 4.1$ ].

Article 11 PLT only provides for relief in respect of time limits fixed by the Office. Hence, the EPO need not provide for further processing in relation to Convention periods in view of the PLT. Nevertheless, in many cases the EPO allows an applicant to file a request for further processing if a Convention period has not been observed although there is an extensive list of Convention periods for which further processing is ruled out.

In the EPC 2000 revision, the scope of application of "further processing" [Article 121 and Rule 135 EPC] was broadened in order to make it the standard legal remedy in cases of failure to observe periods in the procedure up to the grant of the European patent. Further processing is the main remedy under the EPC for non-observance of a period before the EPO. However, the availability of this remedy under the EPO is limited to grant proceedings and to appeal proceedings after refusal of the application. This is in line with the exceptions listed in Rule 12(5) PLT. However, the EPO does not allow further processing in limitation/revocation proceedings [Article 105a EPC].

In addition, the Article on re-establishment of rights [Article 122 EPC] was amended to take account of the broadening of the scope of application of further processing. The EPO will grant a request for re-establishment of rights, provided the prescribed conditions have been met [Article 122(2) and Rule 136 EPC]. In particular, the request for re-establishment must be filed within two months from the removal of the cause of non-compliance with the period, but at the latest within one year of expiry of the unobserved period. What is new in the EPC 2000 is that re-establishment in the priority period [Article 87(1) EPC] has become possible (see $\$ 4.1$ ).

Due to the requirement of proving "all due care" in Article 122(1) EPC, the remedy of re-establishment of rights is not as straightforward and reliable as further processing. In addition, a request for re-establishment does not have suspensive effect on the proceedings. Therefore, any person may, under certain conditions, start using the invention and continue such use without payment. Re-establishment of rights is ruled out for periods in respect of which further processing can be requested. As almost half of the periods in the EPC Implementing Regulations are excluded from further processing, the remedy of re-establishment of rights is, in principle, available in respect of all these periods. In addition, re-establishment of rights is available if the proprietor of a European patent in opposition or subsequent appeal proceedings fails to observe "a period to be 
specified" by the EPO. Because further processing is only possible for applicants, re-establishment is, in principle, available in these periods.

Upon aligning the European Patent Convention with requirements of the Patent Law Treaty, the legislator chose for a relatively complete implementation into the EPC of the requirements in relation to relief in respect of time limits and reinstatement of rights as prescribed in the PLT. In addition, in many cases, the EPO allows relief beyond what is prescribed in the PLT. However, the EPC is not compliant with the PLT in some cases. Although the duration of a large number of periods has been fixed in the EPC Articles and Rules, and although the remedy of further processing is frequently ruled out in respect of these periods, the number of possible remedies available to parties before the EPO is significantly beyond what is prescribed in the PLT.

\subsection{Patent Cooperation Treaty}

In Chapter VII of this thesis, the requirements in the Patent Cooperation Treaty (PCT) for relief in respect of time limits under the PLT and the remedy of reinstatement of rights in the PCT are discussed.

Due to the tight time schedule in the international phase, relief in respect of time limits under the PCT is rather limited. In addition, the duration of the time limits in the PCT Rules is often not specified but only indicated as "within a time limit which shall be reasonable under the circumstances". However, the term "reasonable under the circumstances" lacks definition in the PCT Rules; it also cannot be found in the PCT Applicant's Guide and the PCT Administrative Instructions. The preferred option would be to delete the notion "reasonable under the circumstances" from the PCT in its entirety and replace it by a time limit with a specified (minimum) duration. Where possible, the duration of the time limit should be set to be (at least) two months, thereby promoting alignment of the PCT with the provisions of the PLT.

If the term is maintained in the PCT, a definition including a minimum duration should be incorporated in the PCT Rules. Using undefined terms in legislation, in particular in patent law treaties, puts the applicant in an uncertain position. To make things worse, there are time limits in the PCT without a specified duration and where also the term "reasonable under the circumstances" is not included. The lack of the indication of any duration of time limits should be remedied.

In addition, the frequently-found formulation in the PCT Rules that the time limit "may be extended" by the receiving Office or other responsible Authority "at any time before a decision is taken" also leaves the applicant in an uncertain position: if the Office or Authority has already taken the decision, then there is no remedy in the international phase. So, if the applicant finds out that he has overrun a time limit, he must immediately make a phone call and ask whether the decision has already been taken. This type of discretionary extension should be deleted from the PCT Rules in its entirety. Preferably, it should be replaced by a formulation as can be found in PCT Rule 66.2(e): 
"The time limit for replying to the notification may be extended if the applicant so requests before its expiration." Such a formulation would be compliant with Article 11(1)(i) PLT.

It can be concluded that the existing provisions in the PCT Regulations with respect to the extension of time limits cause a great deal of uncertainty on the side of the applicants and give too much freedom to the receiving Offices and International Authorities who can more or less freely set and determine the duration of the time limits.

During the amendment round of the Regulations under the PCT in April 2007, when a number of PCT provisions was aligned with the provisions in the PLT, the duration of a number of time limits in the PCT was better defined and amended to become two months. In addition, the time limits in the newly introduced provisions were in most cases also set to be two months. As far as known, the PCT system did cope very well with these 2-month time limits. So, it seems that despite the fears with respect to the "tight time schedule" in the international phase, the PCT system is able to deal with situations where the applicants are given more certainty by allowing them more time. This opens a window of opportunity to better define and stretch the duration of other time limits in the international phase of the PCT and, in addition, to consider putting in place a system of allowing extension of a number of time limits. This would promote further alignment of the provisions of the PCT with those of the PLT.

There are no provisions under the PCT for continued processing if the applicant has failed to comply with a time limit fixed by the Office, as provided for under Article 11(2) PLT. The Working Group on Reform of the PCT considered that the inclusion into the PCT Regulations of general provisions providing for the extension of time limits was already regarded as problematic in view of a proper functioning of the PCT system. Adding an additional time limit for allowing the applicant to benefit from continued processing was regarded a bridge too far for the "tight time schedule" of the PCT. However, it would be welcomed by the applicants if at least in the case that the international application is considered withdrawn, a remedy such as continued processing were introduced into the PCT. Introducing of such a Rule with a limited scope and seeing how it works out in practice is conceivable.

The issue of introducing "reinstatement of rights" was discussed in the Working Group on Reform of the PCT in order to promote alignment of the PCT with the requirements in Article 12 PLT. As a result, PCT Rule 49.6 was introduced in relation to the reinstatement of rights after failure to comply with the requirements for national/regional phase entry within the prescribed time limits. The discussions were based on the recognition that Article 3(1)(b)(i) PLT expressly provides that the provisions of the PLT and the Regulations under the PLT are applicable, subject to the provisions of the PCT, to international applications in respect of the time limits applicable under PCT Articles 22 and 39 in the Office of the PLT Contracting Party. In other words, under the PLT, any national Office of a State which is both a PLT and a PCT Contracting Party and which acts 
as a designated or elected Office under the PCT is obliged to apply the provisions of the $\mathrm{PLT}$, in particular Article $12 \mathrm{PLT}$ in relation to reinstatement of rights, to an international application which missed the applicable time limit for entry into the national phase before that Office. PCT Rule 49.6 was introduced into the PCT already on January 1, 2003. Upon adopting the Rule, the option was created for designated Offices to declare that their national law is not compatible with that provision. Unfortunately, the list of States having such reservation is still rather substantial. The WIPO should actively promote the reduction of the number of reservations.

The provision of PCT Rule 49.6 is the only instance where the PCT provides for reinstatement of rights. The Working Group on Reform of the PCT, as far as known, has never discussed introducing the remedy of reinstatement of rights for missing any other time limit in the PCT.

\section{Restoration of priority}

Article 13(2) PLT obliges a PLT Contracting State to provide for the restoration of the priority right in those cases where a subsequent application is filed after the expiration of the priority period, but within a time limit which may not be less than two months from the date on which the priority period expired. A reference to Article 15 PLT was included in Article 13(2) PLT to clarify that due account is taken of the provisions of the Paris Convention. The request for restoration of a priority claim may be filed after the filing of the subsequent application, provided that it accompanies the request for restoration.

In addition, Article 13(3) PLT obliges a PLT Contracting State to provide for the restoration in those cases where a right of priority is lost because of the failure, on the part of the Office with which the earlier application was filed to provide a copy of that application in time, to comply with the prescribed time limit, despite a timely request for that copy having been made. Since the time limit for filing the priority document is normally established by national legislation or under a regional treaty, but not by the Office, a remedy in this respect will normally not be available by way of extension of the time limit or continued processing under Article 11 PLT. The request for restoration of a priority claim may be filed after the filing of the subsequent application, provided that it accompanies the request for restoration.

\subsection{European Patent Convention}

In Chapter VI of this thesis, the requirements in the European Patent Convention (EPC) in relation to the remedy of re-establishment of rights in the priority period and for failure to file a certified copy of the priority application are discussed. In both cases the EPC employs the term "re-establishment of rights" instead of "restoration" as used in the PLT.

For re-establishment of the priority period under Article 87(1) EPC, the minimum time limit fixed by Rule 14(4) PLT has been incorporated: the period for filing such requests 
ends two months after expiry of the priority period [Rule 136(1) EPC]. The normal period of one year for requesting re-establishment of rights does not apply here in view of the central importance of establishing the date of filing and/or priority for the valid claiming of priority.

The procedure for filing priority documents under the EPC is regulated via Rule 53(1) EPC. If the priority document is not provided within 16 months from the earliest period date claimed, the EPO will invite the applicant to provide it within "a period to be specified" [Rule $59 \mathrm{EPC}$; the applicant may request extension of the period before expiry of the normal period. As further processing in the period of Rule 59 EPC is ruled out, re-establishment of rights is, in principle, possible in respect of the late filing of the priority application.

By providing a remedy for the loss of a priority right in relation to the delayed filing of the subsequent application as well as in relation to the failure to file a copy of the priority application in due time, the EPC has been aligned with the requirements of the PLT.

\subsection{Patent Cooperation Treaty}

In Chapter VII of this thesis, the remedy of restoration of the priority right in the PCT is discussed.

By adopting PCT Rule 26bis.3 relating to the restoration of the right to priority by the receiving Office, the PCT was aligned with the corresponding provision in Article 13(2) PLT. The request for restoration can be based on the fact that the failure to file the international application within the 12-month priority period occurred in spite of due care required by the circumstances having been taken or was unintentional, depending on which criterion is applied by the receiving Office. The time limit for filing a request for restoration of the right of priority before the receiving Office was set to be two months from the expiry of the priority period, which is in line with the provisions in the PLT. In the corresponding PCT Rule 49ter.2 in relation to a request for restoration of the right of priority before the designated Office, the applicant is given only one month to file the request; this time limit should be amended to become two months.

Following the adoption of PCT Rules for restoration of the right of priority, options were created for receiving and designated Offices to declare that their national law is not compatible with that provision. At present, the list of PCT Contracting States with such reservations is still rather substantial, thereby reducing the scope and applicability of the provision of restoration of the right to priority under the PCT. The WIPO should actively promote the reduction of the number of reservations.

There is no provision under the PCT for the restoration of the right of priority in those cases where a copy of the earlier application has not been filed within the prescribed time limit. The intention of Article 13(3) PLT is to provide a safeguard in the situation where the applicant cannot submit a copy of an earlier application within 16 months from 
the priority date, because of a delay in the Office with which the earlier application was filed. The Working Group on Reform of the PCT has, as far as known, never discussed the topic. A reason for this may have been that the PCT system already provides enough flexibility to file the required certified copy of the priority document. In addition, the advance in technology away from requesting paper copies and switching to the electronic exchange of priority documents between Offices, Authorities and the International Bureau appears to have diminished the need for introducing a remedy in the sense of Article 13(3) PLT. To this end, already on January 1, 2004 a new paragraph (b-bis) was added to PCT Rule 17.1 relating to the possibility that priority documents may be available to the receiving Office or to the International Bureau from digital libraries. The latter provision is in line with the PLT.

\section{Conclusions}

When the Patent Law Treaty was negotiated in the nineties of the previous century, the emphasis was on making the filing of a patent application as simple and user-friendly as possible. Inventors and small business enterprises were afforded easy access to filing a patent application. The requirements for the accordance of a filing date were reduced to an absolute minimum, rendering it practically impossible to miss this date. As a consequence, procedures had to be put in place at the Offices allowing the applicant to meet additional requirements (such as furnishing a set of claims) at a later stage. All this laid a heavy administrative burden on the Offices which have to deal with such applications.

In the present time, the focus of the national Offices and intergovernmental organizations dealing with national and regional patent applications, is moving away from the needs of the applicants to issues such as how to deal with huge numbers of patent applications in a more efficient manner. Therefore, the procedural requirements of the Patent Law Treaty are regarded as counterproductive to achieving that objective. Perhaps, this is also one of the reasons why accession to the Patent Law Treaty of countries and intergovernmental organizations, such as the European Patent Organization, takes place at a slow pace.

In view of the above, the final conclusions of this study on the alignment of the European Patent Convention and the Patent Cooperation Treaty with requirements of the Patent Law Treaty can be summarized as follows:

(i) The Patent Law Treaty did not achieve the goal of streamlining and harmonizing formal requirements set by national or regional Patent Offices for the filing of national or regional patent applications and the maintenance of patents.

(ii) The Patent Law Treaty contains too many optional requirements which may be implemented as compulsory ("may require") by PLT Contracting Parties allowing them too much freedom when implementing requirements of the Patent Law Treaty in their national and regional patent laws. 
(iii) The World Intellectual Property Organization could play a more active role in issuing instructions and guidelines on how to implement the Patent Law Treaty in national and regional patent laws. A preferred manner of implementing the Patent Law Treaty could be advocated.

(iv) The alignment of the European Patent Convention with requirements of the Patent Law Treaty was done in an exemplary manner. In line with their original intention, the European Patent Organization should accede to the Patent Law Treaty.

(v) In view of the "intimate" relationship between the Patent Law Treaty and the Patent Cooperation Treaty, the latter Treaty could and should have been better aligned with the requirements of the Patent Law Treaty. Too many crucial provisions of the Patent Law Treaty have not been adopted by the Patent Cooperation Treaty.

(vi) The large differences in the degree of alignment of the European Patent Convention with requirements of the Patent Law Treaty as compared to the Patent Cooperation Treaty, obliges the European Patent Office to respond in a substantially different manner depending on whether an applicant files a European patent application or an international application. This counteracts the aim of streamlining the Patent Law Treaty.

(vii) The provision in the Patent Law Treaty allowing an applicant to file a missing part of the description or a missing drawing based on content which is "completely contained" in an earlier application from which priority is claimed, while maintaining the originally accorded filing date, is a powerful tool because it permits an applicant to complete his application without losing his priority claim.

(viii) The option of "filing an application by reference to a previously filed application" as prescribed in the Patent Law Treaty has become outdated by advances in transmission technology and should be abolished.

(ix) The obligation of a PLT Contracting State to provide for relief in respect of time limits either by means of providing an extension of the time limit or by providing continued processing is one of the major achievements of the PLT.

(x) The obligation of a PLT Contracting State to provide for restoration of priority rights is a powerful instrument to rectify mistakes in relation to priority claims, allowing applicants to counteract the unintentional loss of such rights. 


\section{Chapter VII:}

Cees Mulder: Time limits and remedies under the PCT - Compliance of the PCT with the PLT?

has been submitted for publication in The WIPO Journal (2012). 


\section{Curriculum Vitae}

Cees Mulder, born in July 1954 in Tilburg (NL), studied Physics and Chemistry at Utrecht University, where he received his Masters degree in 1977. Subsequently, Cees worked as an officer of the Royal Netherlands Navy at the Physics Laboratory RVO/TNO in The Hague.

After completing his PhD in Physics at Leiden University (1982), Cees joined Philips Electronics, first as a researcher at the Philips Research Laboratory in Eindhoven, and subsequently at the Central Development Laboratories of Philips Lighting. In 1994, Cees joined the Philips Patent department as a patent attorney trainee. Cees qualified as a Dutch patent attorney in 1997 and as a European patent attorney in 1999.

In 2001, Cees and three of his colleagues founded a private patent attorney office called DeltaPatents in Eindhoven. Here Cees was not only able to continue his activities in the field of patents, but also to establish DeltaPatents as a leading institute for training patent professionals in Europe, in particular patent attorneys, for the European Qualifying Examination. In July 2009, Cees resigned from partnership in DeltaPatents and became Senior Adviser.

In the period from 2002 to 2009, Cees Mulder was the main author of a set of two books: "Basic Questions and Answers for Paper D" and "Exam-related Questions and Answers for Paper D", issued by DeltaPatents (yearly updated). These booklets are used by candidates preparing for the legal questions in the European Qualifying Examination. In surveys carried out by the European Patent Office among all candidates after the examinations, the students identify these books as being most helpful in the preparation for the Exam.

Since 1999, Cees has been a tutor at the Centre d'Etudes Internationales de la Propriété Intellectuelle (CEIPI) at the Strasbourg University and, since 2005, he has been co-speaker at the "Guide to the Formal Requirements of the European Patent System for Administrative Staff in the Patent Profession" at Management Forum in London.

Cees is a senior lecturer in many courses on the European Patent Convention (EPC), the Patent Cooperation Treaty (PCT) and the Paris Convention (PC). Occasionally, Cees cooperates in projects with the European Patent Office in Munich and the World Intellectual Property Organization in Geneva.

Since 2003, Cees has been the author of the book "The Cross-Referenced Patent Cooperation Treaty" (published yearly).

Since September 2009, Cees Mulder has been a Lecturer in European Patent Law at the Faculty of Law of the Maastricht University in the Department of International and European Law (Prof. Anselm Kamperman Sanders). As vice-director of the "Advanced Master Intellectual Property Law and Knowledge Management (LLM/MSC)" at Maastricht 
University (NL), Cees is involved in the management and teaching of the Master track in general, and the MSc-track in particular.

Since the Academic year 2010-2011, the IPKM has been accredited by the European Patent Office: MSc graduates benefit from a remission of the period of professional activity required for admission to the European Qualifying Examination for European Patent Attorney. 